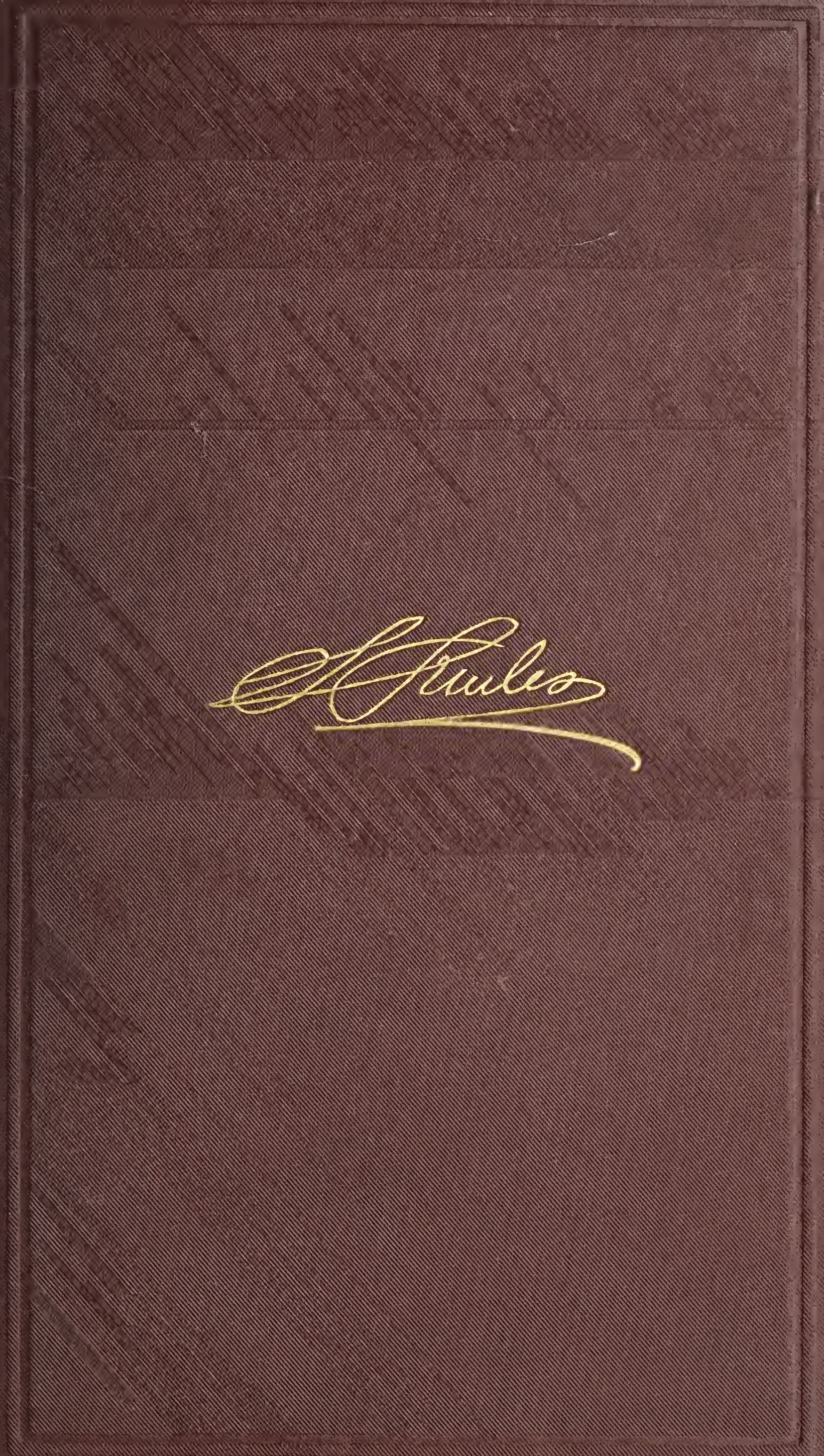




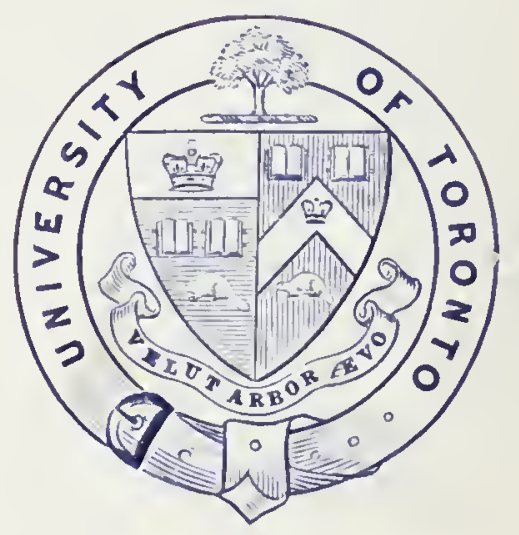

Prescuted to

The Tibrary of tbc

\section{University of Toronto}

$$
\text { Pies R. Ballon. }
$$





ROBERT DIOK 
Digitized by the Internet Archive in 2018 with funding from University of Toronto 



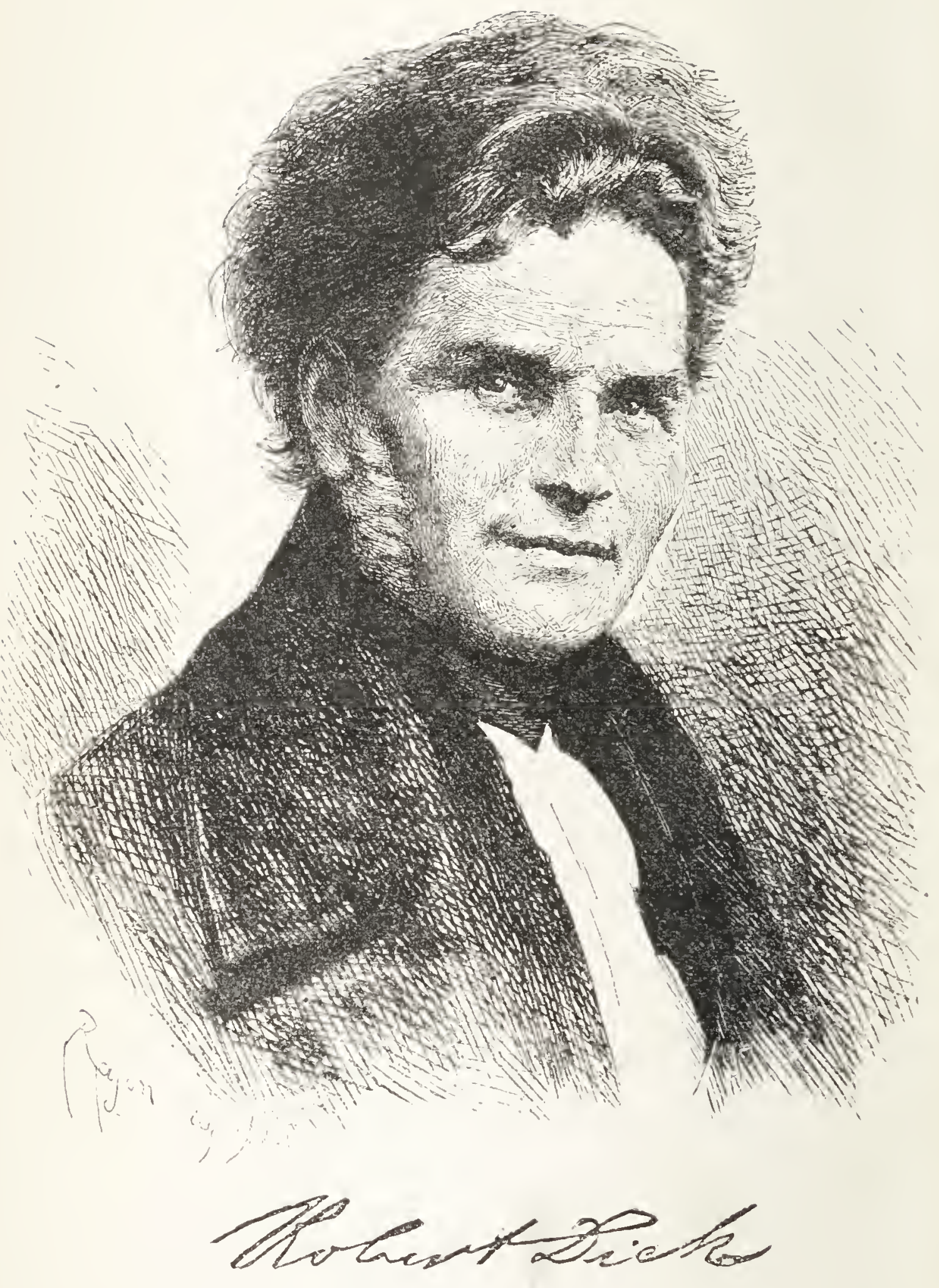




\title{
ROBERT DICK
}

BAKER, OF THURSO

\section{GEOLOGIST AND BOTANIST}

\author{
By SAMUEL SMILES, LL.D. \\ AUTHOR OF "LIFE OF A SCOTCH NATURALIST" "SELF-HELP" "THRIFT" \\ "CHARACTER" ETC.
}

WITH A PORTRAIT' AND NUMEROUS ILLUSTRATIONS

"In Nature's infinite book of secrecy

A little I can read."

Shakespeare.

"The heights by great men reached and kept

Were not attained by sudden flight;

But they, while their companions slept,

Were toiling upwards in the night."

LONGFLLLOW.
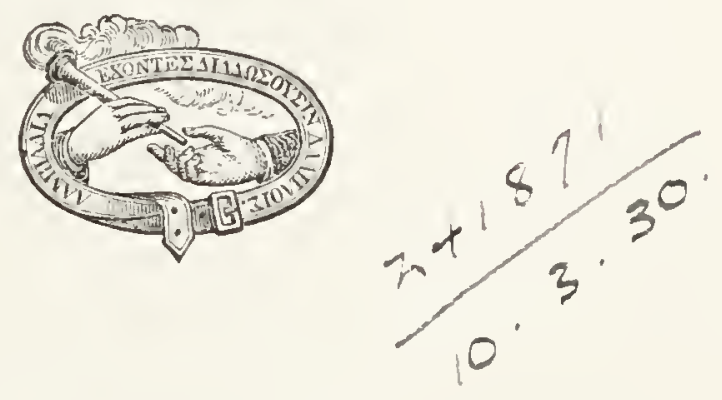

NEW YORK

HARPER \& BROTHERS, PUBLISHERS FRA NILIN SQUARE 


\section{BY SAMUEL SMILES.}

SELE-HELP; with Mlustrations of Character, Conduct, and Perseverance. A New Edition. 12mo, Cluth, \$1 00.

CHARACTER. 12mo, Cloth, $\$ 100$.

THRIFT. $12 \mathrm{mo}$, Cloth, $\$ 100$.

DUTY; with Illustrations of Courage, Patience, and Endurance. 12mo, Cloth, $\$ 100$.

HISTORY OF THE HJGUENOTS. The Huguenots: their Settements, Churches, and Industries in England and Ireland. With an Apleudis relating to the Huguenots in America. Crown 8 ro, Cloth, $\$ 200$.

THE HUGUENOTS AFTER THE REVOCATION. The Huguenots in France after the Revocation of the Edict of Nantes: with a visit to the Country of the Vaudois. Crown $8 \% 0$, Cloth, $\$ 200$.

LIEE OF THE STEPHENSONS. The Life of George Stephenson, and of his Son Robert Stephenson; comprising, also, a History of the Iuvention and Introduction of the Raihway Locomotive. With Portraits and numeruus Illustrations. $8 \mathrm{ro}, \mathrm{Cloth}, \$ 300$.

ROUND THE WCRLD; includiug a Residence in Victoria, and a Journey by Rail across North America. By a Luy. Edited by Samuel Sulles. With Illustrations. $12 \mathrm{mo}$, Cloth, $\$ 150$.

LIEE OF A SCOTCH NATURALIST: Thomas Edward, Associate of the Linnzern Society. $12 \mathrm{mu}$, Cloth, $\$ 150$.

Published by HARper \& Brotilers, New York.

Sent by mait, postage prepaid, to any part of the United States or Canada, on receipt of the price. 


\section{PREFACE.}

The preparation of this book has occupied me at intervals during several years. It would have been published before the Life of a Scotch Naturalist, but for want of the requisite materials.

I have to thank my reviewers, one and all, for their favourable notices of that work. It has, however, been objected that I should have culled my last example of Self-Help from a career not already concluded, and exposed the Scotch Naturalist, after his long unmerited neglect, to the harder trial of intrusive patronage, to which my premature biography was likely to expose him.

Whatever truth there may be in this objection, it certainly does not apply in the present case. Robert Dick died twelve years ago, without any recognition of his services to the cause of science, and without any of that Royal Help which, as in the case of Edward, is likely to render the later years of his life more free from care and anxiety.

The first account that I heard of Robert Dick was from the lips of the late Sir Roderick Murchison. He 
delivered a speech at Leeds on the occasion of the meeting of the British Association, which was held there in September 1858.

"In pursuing my researches in the Highlands," said the Baronet, "and going beyond Sutherland into Caithness, it was my gratification a second time to meet with a remarkable man in the town of Thurso, named Robert Dick, a baker by trade. I am proud to call him my distinguished friend. When I went to see him, he spread out before me a map of Caithness and pointed out its imperfections. Mr. Dick had travelled over the whole county in his leisure hours, and was thoroughly acquainted with its features. He delineated to me, by means of some flour which he spread out on his baking board, not only its geographical features, but certain geological phenomena which he desired to impress upon my attention. Here is a man who is earning his daily bread by his hard work; who is obliged to read and study by night; and yet who is able to instruct the Director-General of the Geographical Society.

"But this is not half of what I have to tell you of Robert Dick. When I became better acquainted with this distinguished man, and was admitted into his sanctum - which few were permitted to enter-I found there busts of Byron, of Sir Walter Scott, and other great poets. I also found there books, carefully and beautifully bound, which this man had been able to 
purchase out of the savings of his single bakery. I also found that Robert Dick was a profound botanist. I found, to my humiliation, that this baker knew infinitely more of botanical science-ay, ten times more-than I did; and that there were only some twenty or thirty British plants that he had not collected. Some he had obtained as presents, some he had purchased, but the greater portion had been accumulated by his own industry in his native county of Caithness. These specimens were all arranged in most beautiful order, with their respective names and habitats; and he is so excellent a botanist that he might well have been a professed ornament of Section D [Zoology and Botany]. I have mentioned these facts," concluded the Baronet, "in order that the audience may deduce a practical application."

This notice of Robert Dick, by a man of so much eminence as Sir Roderick Murchison, interested me greatly. His perseverance in the cause of Science, while pursuing the occupations of his daily labour-his humility, his modesty, and his love of nature-were things well worthy of being commemorated. But I was at that time unable to follow up my inquiries. I could merely mention him in Self-Help, which was published in the following year, as an instance of cheerful, honest working, and of energetic effort to make the most of small means and ordinary opportunitics. 
Many years passed. Robert Dick died in 1866. Was it possible that he had left any memoranda on which a memoir of his life and labours could be written ? On inquiry I found that many of his letters were still in existenee. I believe that I have been sueeessful in obtaining the greater part of them, or, at all events, those which are the most interesting. In fact, by means of these letters the story of Dick's life has in a great measure been told by himself.

One of his principal corresponcients was the late Hugh Miller, author of My Schools and Schoolmasters, The Old Red Sandstone, and other geological works. His son, Mr. Hugh Miller, of the Geological Survey, has kindly sent me Dick's letters to his father; though Hugh Miller's letters to Dick have not yet reached me. They are supposed to be in Australia.

Mr. Charles W. Peach, A.L.S., one of Dick's best friends, has sent me all Dick's letters to him, together with much other valuable information as to his life and character. But perhaps the best of Diek's lettersthose containing his references to his private life were those written to his sister, prineipally for her amusement; and these have been kindly placed in my hands by Dick's brother-in-law, Mr. Faleoner of Haddington.

I am also indebted to Dr. Meiklejohn, to Dr. Robert Brown, F.L.S., for many letters; and to the 
Rev. William Miller, A.M., Thurso, for the letters sent by Dick to his uncle, the late Mr. John Miller, F.G.S.

Among those who have also favoured me with valuable information as to Dick's life, I have to mention Mr. Brims, Procurator-Fiscal, Thurso; Mr. G. M. Sutherland and Mr. Ficlding, Wick; Professor Shearcr, Airedale College, Bradford; and Dr. George Shearer, Liverpool.

With respect to the Illustrations, they have, for the most part, been the result of screral journcys which I have made round the coast of Caithness, and also into the inland districts frequented by Robert Dick, while making his numerous journeys in scarch of fossils, boulder clay, ferns, plants, and grasses.

The illustrations have been much improved by being drawn on the wood by such accomplished artists as Leitch, Skelton, and Boot, and engraved by Cooper, Whymper, and Paterson.

Mr. Sheriff Russell of Wick and Mr. Charles Peach of Edinburgh have also given me their assistance in the preparation of the illustrations.

The engraving of Mr. Peach has been executed by Charles Roberts, after a photograph by Mr. Dallas, Edinburgh.

LoNdon, Noveneer 1878. 


\title{
CONTENTS.
}

\author{
CHAPTER I.
}

TULLIBODY.

The village of Tullibody-Windings of the Forth and Devon-Scenery of the Devon-The Ochils-Castle Campbell-Rift in the Ochils - Menstrie - Bencleuch - The Picts - The "Standing-Stane" Cambuskenneth-The French at Tullibody - The Abercromby family .

\section{CHAPTER II.}

\section{ROBERT DICK'S BOYHOOD.}

Robert Dick's birthplace-His mother-The children sent to schoolTeacher of the Barony School-Robert Dick an apt scholar-His talent for languages-Resides at Dam's Burn-Schoolmaster at Menstrie - Climbs the Ochils - Life at home-His stepmother -Family difficulties-What Dick learnt as a boy-He leaves home .

- Pages 8-16

\section{CHAPTER III.}

ROBERT DICK APPRENTICED.

Apprenticed to a baker-Life of a baker's boy-His early and late lours-Delivering the bread-His observations of Nature-First acquaintance with Botany-Remembrance of the plants of the Devon-His sister Agnes-His day of rest-A great reader-Mr. Dick removes to Thurso-Robert Dick leaves Tullibody-A journeyman baker at Leith, Glasgow, and Greenock-Removes to ThursoBegins business in 'Thurso-Thurso Bay-His delight in the seaThe sea-bird's cry

- Pages $17 \cdot 25$

\section{CHAPTER IV.}

\section{DESCRIPTION OF CAITHNESS.}

The name "Caithness"-Nesses along the coast-Caithness Scandi- . navian-Wicks in Caithuess-Saetrs, Dahls, Thorsa-The people- 
Firths or fiords-The Piets drowned-Currents in the Pentland Firth-Stroma-Pentland Skerries-The furious winds in Caithness-No trees or hedges-Barrogill Castlc-The coast sceneryWick Bay-Duncansby Head-The Stacks-John o' Groats-The old castles-Al-wick, Keiss, Girnigo-The Gyocs-The inland country-The Caithness mountains-The great mountain, Morven -Agriculture-The old Caithness plough-Thurso-Roads-Crubbans-Ord of Caithness-Sir John Sinclair-Thurso Castle-Road over Bencheilt-Sir John Sinclair's improvements . Pages 26-39

\section{CHAPTER V.}

\section{DICK BEGINS BUSINESS,}

Wilson Lane, Thurso -- First flour bought - Studies conchologyBotany-His father lcaves for Haddington-Dumnet Head, Holborn Head, and the Clett-The Gyoes-The inland countryEntomology-Beetles, Bees, Butterflies, and Moths-The boys follow Dick-Makes friends of the boys-Rare insects brought to him-Astronomy, Geology, Phrenology-Dick invited to marryAnnie Mackay - Mechanical method for making biscuits-His biscuits

Pages 40-49

\section{CHAPTER VI.}

BOTANICAL WANDERINGS.

His entomological collection-Tested everything by observation-His books-Books imbedded in his flour-His microscope-Hogarth's works-A great reader-Botanical excursions-Spring in the North - Watching the growth of the flowers-The ferns-Caithness flora —Study of Botany-Midsummer time-Solitude-The moors-The soaking rain-Walking for a fern-Standing on a hill-top-Letters to his sister-Walking over a moor-Journey to Morven topDick taken for a salmon-poacher . . . Pages 50-69

\section{, CHAPTER VII. \\ DISCOVERS THE "HOLY GRASS."}

Business and science-Want of friends-His dress-His love of nature -A deputation from the boys-Dick a general referee-His knowledge of plants-The Ifierochloë borecalis--Retains the discovery for twenty years-Dick's paper on the subject-The Royal Botan:cal Seciety, Edinburgh_-The MIoonwort-The Stork's-bill-Pursuit of ferns-Dunnet Sands-The Dorery Hills-Loch Shurery-Dick's ferncry at the Reay Hills . . . . Pages 70-80 


\section{CHAPTER VIII.}

\section{DUNNET HEAD.}

The coast scenery near Thurso-Holborn Head-The rockbound coast - The Gyocs-Fury of the waves-Serabster Roads-New rocks laid bare-Dunnet Head a favourite haunt-Height of the eliffsExtent of the peninsula-Dwarwiek Head-Yachting trip round Dunnet Head-The gyoe near Dwarwiek-The sca-birds-'The lighthouse-Slips of the rocks-Diek's journey to Dunnet HeadDunnet sands-Over the heather-Down the cliffs-Seareh for ferns-Overtaken by the sca-Dick found by a pleasure partyGeology of Dunnet Head-Devoid of organisms-The sandstone cliffs-Sandstone from shore to shore-Roeks at Brough-Dunnet Loeh-A superstition of Caithness . . . Pages 81-97

\section{CHAPTER IX.}

\section{GEOLOGY-DISCOVERY OF A HOLOPTYCHIUS.}

Studies Geology-Mantell and Buckland-Hugh Miller's Old Ricd Sandstone-Addresses Hugh Miller-The Holoptyehius-Describes the beginning of his studies-Hugh Miller's aeeount of DiekGentlemen-geologists-The scalding theory-Diek sends his fossils to Hugh Millcr-Hugh Millcr's aeknowledgments . Pages 98-109

\section{CHAPTER $\mathrm{X}$.}

\section{GEOLOGY OF THE THURSO COAST.}

Invitations to Hugh Miller-Deseription of the coast-Thurso EastFossiliferous beds_-"That man is mad"-View from the coastPudding Gyoe-Nurkle Bay-View of Dunnet eliffs-Geologising at Serabster-The sca-The Coccosteus-An old burying-groundBishop's Palace_Serabster Roads_Holborn Head_The Deil's Brigg -The Clett-Slater's monument-Brims-Searching for fossils on Holborn Head

- Pages 110-128

\section{CHAPTER XI.}

\section{HUGH MILLER VISITS DICK.}

Diek's obscrvations in geology-Opposed to theorising-Dip of the strata-How came the fossil fish? - The flagstones of CaithnessGeological formation of Caitlness-Elevation and depression of the 
land-Differences of climatc-The glaciers - The boulder elayBeds of coal-Diek sends his fossil remains to Hugh Miller- $A$ bundle of findings-Dick publicly mentioned-Weydale-An auld bachelor-Dipterus and Diplopterus-The quarrymen and the fossils -Banniskirk_"Fresh herring"-Walking sentry - Reconnoitres for Hugh Miller-Hugh Miller visits Robert Dick-Their walks along the shore-Dunnet sands and Dunnct Hcad-Holborn Head -Deseription of Hugh Millcr-The expatriated Highlanders-

"Donald's Flittin" . . . Pages 129-150

\section{CHAPTER XII.}

DEATH OF DICK'S FATHER-THE BOULDER CLAY.

Thomas Dick at Haddington-Removes to Tullibody-His illness and deatl -Letter to his sister-Competition at Thurso-His absence from "the Kirk"-The reason why-Dick's solitary service-His collection of fossils-Rescarches into the bouldcr clay-His journeys by daylight and moonlight-Boulder elay along the Thurso river - Finds marine shells and flints-Thurdistoft-Bclts of elayHarpsdale-Sends Hugh Miller the marine shells Pages 151-166

\section{CHAPTER XIII.}

\section{DICK'S SEARCHINGS AMONGST THE BOULDER CLAY.}

A journey to Freswick-Starts at midnight-Castle of Freswick-. Wanderings up the burn-Finds marine shells-Hugh Miller's conclusions-'The eastern side of Dunnet Head-Dick's walk under the break-neck rocks-Cliffs at Brough-Gocs into a boulder elay ravine-Proceeds down a ledge-Wonder upon wonder-Dick's reflections-Journey to Harpslale-Another visit to FreswickBoulder stones-Village of Castletown-Wild bulls of DumctMoss of Mey-The Skerry Lights-Stroma Isle-The Wart HillWades along Freswick Burn-Searches amongst the boulder elayAll the country once occupied by the sea-Dick's conclusions

Pages 167-191

\section{CHAPTER XIV.}

\section{ICEBERG PERIOD.}

Action of iccbergs - Journey to Dunbeath-Crosses Caitliness from north to soutl_-Granitie débris-Dunbeatl Water-Finds marine shells-Granite and conglomerate-The boulders-Tle moorsInch More-The auld earle-The want of sneeshin-Deceived by 
the auld carle-Formation of Caithness-Journey to AcharyniePieturesque appearance of the river-Dirlot Castle-Dallmore and Cattack-Strathbeg-Journey to Sinclair Bay-Noss Head-Various other journeys-Visit to Shurery-View from the Ben-TValk up Strath Halladale-Journey aloug the Pentland Firth-The Haven of Mey-The Caddis worm

- Pages 192-213

\section{CHAPTER XV.}

\section{END OF CORRESPONDENCE WITH HUGH MILLER.}

Dick's assistance to Hugh Miller-Professor Agassiz's testimonyProfessor Sedgwiek-Specimen of the Diplopterus-Professor Owen - Hugh Miller's aeknowledgments-Ruling by authorities-Geological maps-Dick's travelling map-Government should make the maps-One first creation-Winter in Caithness-Groovings of ice-Rolling home an Asterolepis-How Diek polished his fossilsWorking among the rocks, at Barrogill, Mull of Mey, SearskerryThe base at Gill's Bay-Seotland Haven-Ramble to BeneheiltThe Druid's Tcmple—Stemster Loch_-Bed over bed_-Hugh Miller's works-Popes of all sorts-Hugh Miller's death_Dick's story of "The Fiiries"-Diek's lamentations orer Iugh's death

Pagres 214-237

\section{CHAPTER XVI.}

\section{CRARLES W. PEACH, A.L.S.}

Anothe: worker among the roeks in Cornwall-Charles Peach--How working men may advance knowledge-Peach and Dick-Peach born at Wansford-His schooling-Assists in his father's imn-Is appointed riding offeer in the Coastguard service-Studies Natural History-His frequent removals in Norfolk-The Rev. J. LaytonSuperintendent at Cley-Removed to Lyme Recis, Beer, Paignton, and Gorranhaven-Studics Zoology-The Gcology of the Cornish coast-Reads a paper at the British Association-Constant attender at the meetings-The meeting at York-Dr. R. Chambers' deseription-Discovery of the Holothuria nigra-Charles Peach promoted to Landing Waiter at Fowey-His discovery of organic fossils-. Testimony of the Royal Cornish Geologieal Society-Removes to Peterhead-Continues his studies in Zoology and Botany-Removes to Wiek-His first visit to Robert Dick-His seeond visit to Dick - Their walks - Battles in Dick's bakehouse-Peach discovers fossils in the limestone of Durness-Effects a revolution in Geologiy 


\section{CIIAPTER XVII.}

\section{ROBERT DICK AND CHARLES PEACH.}

Peach finds a new fossil-Dick's reply-The monk of Cambray reading backwards-Views of Gcology-Ill-will to geologists-Mr. Pcach's paper at Livcrpool-Fossil wood-Dick's botanical collectionMr. W. L. Notcutt-Dick's correspondents-His Sunday walksDr. Macleod-“"Ta tail pe brak"-Encounter with a HighlanderSir Roderick MIurchison-Calls on Robert Dick-Letter from Sir Roderick-Second visit to Dick-Moulds a map of Caithness in flour-Sir Roderick's lettcr-Voyage of Murchison and Peach to the Shetland Islands-Sir Roderick's specch at Lceds- "Hanmers an' chisels an' $a$ " "-Amygdaloid-Dick's rhymes-Another letter from

Sir Roderick-Another rhyme . . . Pages 259-281

\section{CHAPTER XVIII.}

\section{LION-HUNTERS-FERNS AND MOSSES.}

Thurso people and Dick-Opinions about his rhymes-Lion-huntersAnnic Mackay_The Duke of Argyll—Sir Gcorge Sinclair-Thomas Carlyle and Baroness Burdett Coutts-Lady Sinclair-"Welcome Charlie"-Medical students-Dr. Shearer-Dr. Meiklejoln-Dr. Brown-The Juncus squarrosus-Study of mosses_Club mossesFinds the Osmunda regalis-Ferns on Dunnet Hcad-Cornish heaths_Studies from Nature-Fossil wood-Illness-Hart's-tongue fern-Section of Caithness strata-Plants the Royal Fern over Caithness - Darwin's Journal - The littleness of things-Dr. Shearcr's question-Corrcspondence with Dr. Meiklejohn-Influence of climate on roses . $\quad . \quad$. $\quad$. . Pages 2S2-311

\section{CHAPTER XIX.}

ROBERT DICK IN ADVERSITY.

Dick's attention to business-Is oppressed by competition-Loses his money-Loses his health-Thinks of removing from Thurso-More bakcrs-Bakcrs and whisky dcalers-John Barleycorn-No coddling and nursing-Improvement of Thurso-Annic Mackay's conversation, Dick's housekeepcr-Dick's honesty-His cleerfulnessKceps moving-Porcs over dried mosses-_acob's son-Eyesight becomes defective-His struggles to live-SirWyville Thomson-His description of Dick-Dick resuncs his researches among the fossils - His grcat labour-Finds an extraorlinary fossil . Parges 312-328 


\section{CHAPTER XX.}

DICK COMPELLED TO SELL HIS FOSSILS.

The "Prinee Consort" shipwreeked-Diek's flour lost-Unable to pay the loss-Appeals to his sister-Obtains $£ 20$ from her-Prepares to sell his fossils-Mr. Jolm Miller, F.G.S._- Correspondenee with him-Writes to Sir Roderiek Murehison-Sells his fossils to Mr. Miller-Pays his bill for the lost flour-His business again falls off - Nature comes to his relief-His lonely walks-His favourite resorts-The Daisy-The Bulrush and Lapland ReedTroubled with rheumatism - Native roses-Professor Babington -Professor Owen-Mr. Noteutt-Mr. Pring'te, Farmer's Gazette-"O waft me o'er the deep blue sea"-Dick a sleepless man-St. Peter's burying-ground-A believer in the unseen world . Pages 329-347

\section{CHAPTER XXI.}

RECOMMENCES A COLLECTION OF FOSSILS.

Again searehes for fossil fish-His wondrous astonishment-The dead fish-Platform of death-View of Caithness and Orkney-Death a neeessity - Interwiew with a quarryman - Hugh Miller's views referred to-The old Red conglomerate-Searehings among the roeks - A large fossil found-Searehes for an entire fossil fish-His constant diggings-Mr. Salter's lecture-Digs in hard frost-Order of succession-Bed of rolled pebbles on Morven top-Stony elays on Thurso river-Metamorphic aetion-Liquid silica-Flint castsThe chalk formation-Diek's letter's

- Pages 348-370

\section{CHAPTER XXII.}

DICK'S FRIENDS-FOSSILISING AND MOSS-HUNTING.

How the Thurso people regarded Dick-His antediluvian garmentsHis appearanee-His inner thinkings-The little we really knowDignity and purity of Diek's eharneter-Dr. Shearer's statement as to his thoroughness-Peaeh and Dick-Careful and abstemious"No pampering"-Correspondence with his sister-Ferns in December, Peri-Diek nearly shot-Death of his sister-A new friend -His meeting with Diek-His frequent interviews-Diek's museum described-His lierbarium-Walls of his bakehonse-His interest 
in Egypt-Natural History Soeiety of Thurso-A museum-More correspondents-MIr. Jamieson, Lllon-Lines to Charles PeachAward to Peach for his diseoveries in geology-Peach firds new fossils-A sea-smake-Pterichthys Dicli-Peach's duties-Retires from the serviee—Continues the study of geology and zoology-Diek's letter on receiving his plotograph .

- Pages 371-391

\section{CHAPTER XXIII.}

DICK'S LAST IEAR-HIS DEATH.

Diek afllieted by rheumatism-Competition in business-His trade suspended-His biseuits-Searcely earns the wages of a day-labourer -A good new year-Collecting mosses and ferns-Reform-The rain-Working at fossils again-The eld days gone for ever-A boulder stone from Helmsdale-Eishop Colenso's book-The Thurso merchants-Mrr. Carlyle's oration-Railway projeets-Diek pietures himself-Dick's last walk-His deseription-His illness-Mr. Miller's helpfulness - Continues to work-His last letters-Mrs. Harold-Robert Diek's death-A public funeral-Followers to his grave-Winding up of his affairs-Sale of his library-The proposed pension-'ioo late.

- Pages 395-416

\section{CHAPTER XXIV.}

\section{CHARACTERISTICS.}

Diek self-saerifieing life-Unhappiness in his bringing up-His delight in nature-His love of faets-The mystery of geology-Its wonders - His researches among the rocks and boulder clay-His unselfishness-His givings to Hugh Miller-Hugh Miller's acknowledgments - His extraordinary journeys-Neeessity for work-His intelleetual labour-His modesty-His enthusiasm-His closeness of observation-His idea of geology-His collections of fossils-His lerbarium - His eharaeter-His ehildlikeness—Sir George Sinelair's testimony - Professor Shearer-Charles Peael_-His poverty_Annie Mackay -Dick a reverent and devont man-Miral of Dick's life 


\section{ILLUSTRATIONS.}

Portrait of Robert Dick: Etched by Paul Rrijon. Frontispiese. Engrared by

Portrait ol Cinarles W. Peacin, A.L.S. C. Roberts. To faee page 238

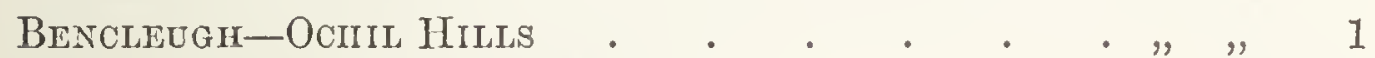
Rift in the Oculls, nenr Menstrie • . . . page 3 Robert Dick's Birtilplace, 'I'ullibony • • . . Dam's Burn, foot of the Ochils . . . . . " 11 Dunmyat, from Cambugkentetil . • . • " $" 17$

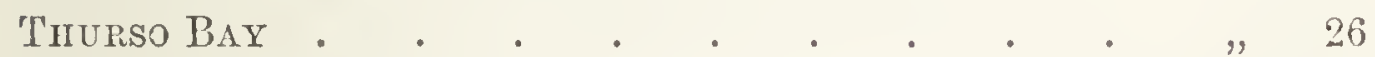
Mlap of Caitinness . . . . . . . To face page 26 Girnigo Castle, East Colst of Caitintess . . . page 32

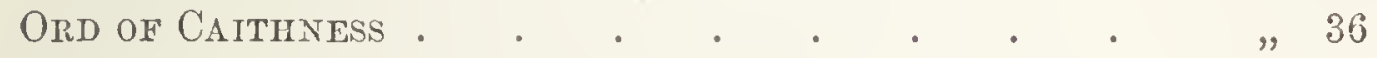
Duncansby Head, Near Jofin o' Groat's . . • " 39 The Clett, Holborn Head . . . . . To face page 44 Old Thurso Castle, from tile Shore . . . . page 54 Morven Mountain . . . . . . To faee page 66 The Dorery Hills . . . . . . . page 79 Dwarifick Head . . . . . . . . " 84 Dunnet Hend, from the East . . . . To face page 86 Distant view of Dunnet Head, from Bariogili Castle page 97 Map of Coast near Tiluriso • • • • . . "110 Hox Head and Man of Hoy . . . . . " 115 Bishop's Palace and Scrabster Roads • • • " 121 The Deil's Brig, Holborn Head • . . To face page 124 Dunnet Sands . . . . . . . page 143 Rocks at Holborn Head-Slater's Monument T'o fece page 146 Tituraso River, from the Bridge . . . . . page 160 Stacks of Duncansey . . . . . . . . " 166 Freswick Castle and Headlatd . . . " 160 
Dunnet Cliffas, Eastenn Side

page 173 Rocks at Brovgir . . . . . . . To face page 174 Castlehill House, Castletown . . . . . page 180 The Skermy Lights, Pentland Firth : from Canisbay

To face page 182

Boulder Clay at Freswick . . . . . . page 184 Freswick Bridge • • • • • • • • ” 186 Dunbeatir : East Coast of Caitinness • • " " 193 Ruins of Dirlot Castle • • • • • " 202 Sixclair Bay and Noss Head • • • • • " 205 Strath Halladale • • • • . . To face page 208 Moutir of Strath Halladale River • • • . page 210 Dunnet IIead : Wrast Froxt-Near the Lighthouse

To face page 232

Wansford, Nomtinamptonsmime . • . • . page 240 Charles Peach's House at Fotwey • • • • " 249 Robert Dick's House, Wilson's Lane, Tiuurso • • " " 271 Thurso Harbour: the Old Church • . . . " 274 Old Thurso Castle 。 • • • • • • „286 Dunnet Head :- Wrest Front • • • • To face page 296 Dick's Seat at Donery: View into Sutherlandsinie page 303 Thuriso Parish Church, from the Wick Road • • " 317 Ruins of St. Peter's, 'Thurso . • . • . " 347 Distant View of Monven and Maiden Pap • • " 350 Miouth of Thurso River . . • . . . ”3S4 Mill at Forss • • • • • . . To face page 388 Monument to Robert Dicik in Thuriso Cemetery " „ 416 New Thurso Castle • • . • • • . page 432 



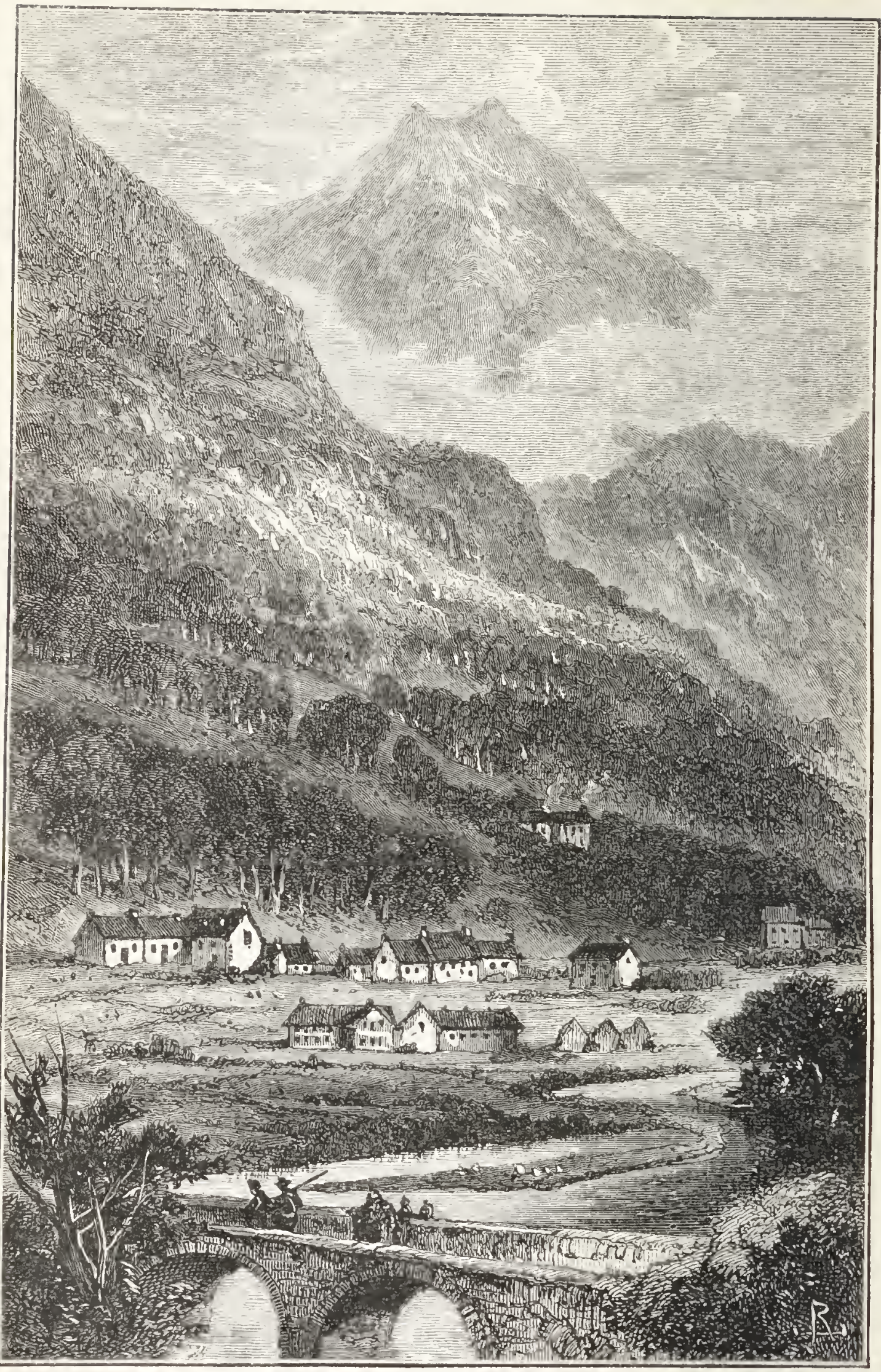

BFXCLELGII : OCHIL HILLS. 


\title{
ROBERT DICR.
}

\author{
CHAPTER I.
}

T'ULLIBODY.

THE village of Tullibody stands upon a rising ground situated between the windings of the Forth and the Deron, in Clackmannanshire, Scotland. The Devon takes its rise among the burns and rivulets which flow down from the Ochil Hills.

At the upper part of the river, some of the most romantic scenery in Scotland is to be found. At the Caldron Linn the Devon forms a series of cascades, which rush down through precipitous rocks into almost unseen depths. Boiling about in the Caldrons, it passes with a violent noise under the Rumblin' Brig, which spans the rocks about a hundred and twenty feet above the bed of the river.

Another affluent of the Devon comes down from the Ochils at Castle Campbell-Castle of Gloom, as it used to be called - a ruined building occupying a wild and romantic situation on the summit of a high and almost insulated rock. The mount on which it is situated is nearly encompassed on all sides by thick bosky woods; and the mountain rivulets which tumble down through 
the chasms on either side, become united at the base. The whole of the scenes about the upper Devon are of the most romantic kind, and are strikingly different from all other Scottish scenery.

As the river winds out from its rocky bed below the Caldron Limn, it enters the beautiful open valley which runs along the foot of the Ochils, taking on its way the rivulets which flow down from the mountains. It runs westward near Dollar, Tillicoultry, Alva, and Menstrie; then, winding sharp round towards the south near Tullibody, it joins the Forth at Cambus, a little below the ruins of Cambuskenneth Abbey.

Among his many beautiful verses descriptive of the rivers of Scotland, Burns has not forgotten the Devon :-

"How pleasant the banks of the clear winding Devon, With green spreading bushes and flowers blooming fair!"

The verses were composed as a poetic compliment to Miss Charlotte Hamilton, a charming lady, then residing at Harvieston, near Dollar.*

The lofty range of the Ochils is a prominent feature in the scenery of the Devon. The hills are soft, green, and pastoral. Their sunward slopes are here and there varied with magnificent wooded glades, intermingled witi copse and whins, which in their golden summer yellow are supremely beautiful. The burns and streamlets come down in cascades through the deep rifts of the hills, and are turned to use in many mills along the valley.

* Near Dollar is "Tait's Tomb," the family burial-place of the Archbishop of Canterbury, whose father built Harvieston, and bceame the possessor of Castle Campbell. 


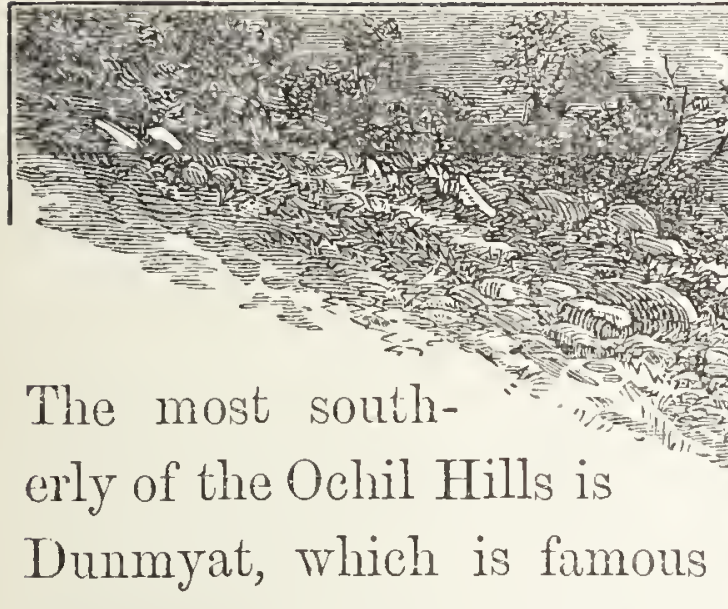
for the extensive view obtained from its summit. A little to the east of it rises Bencleuch, the highest hill in the range, 2352 feet high. It shoots up into a tall rocky point, called Craigleith, famous in ancient times for the production of falcons. In a hollow behind the point, where the sun's rays never extend, the snow lies far into the summer. The people of the neighbourhood give it the name of Lady Alva's Web.

The little town of Alva

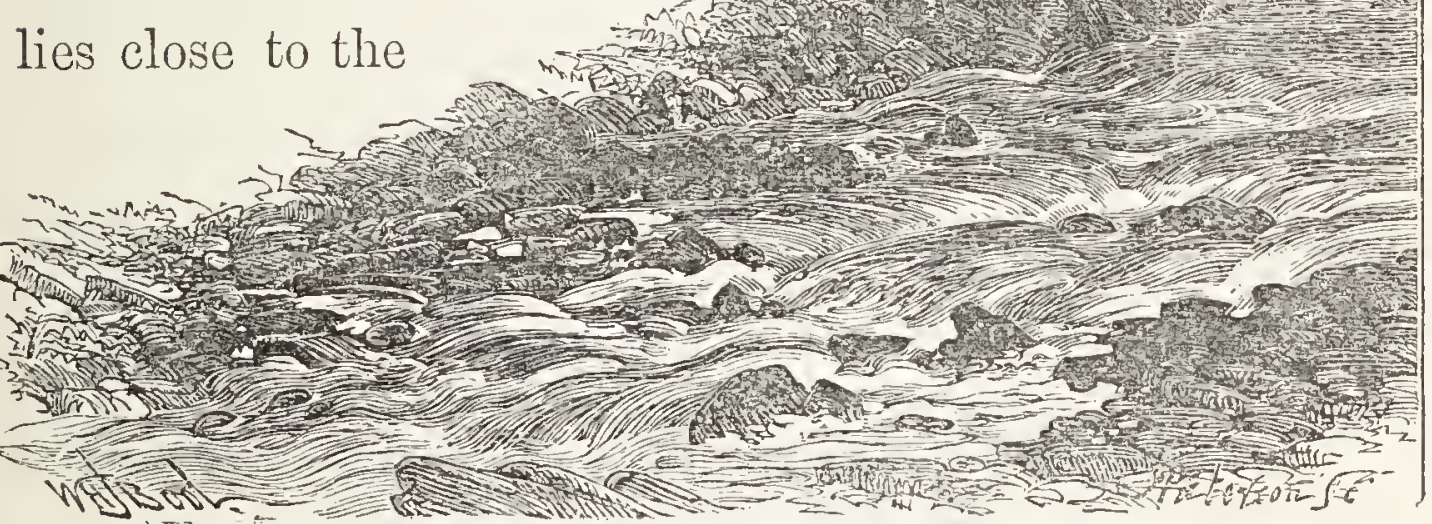
1. at

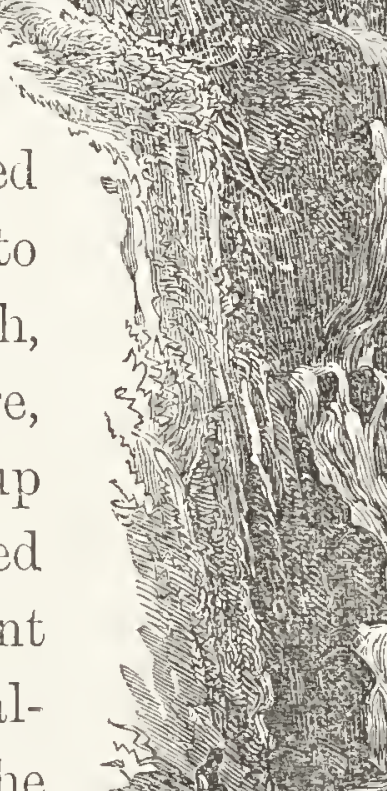
(2) 7ry

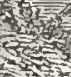
Ply is 3.3. hith

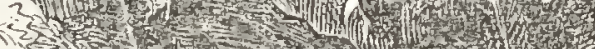
H. 3. 17. -5 ,

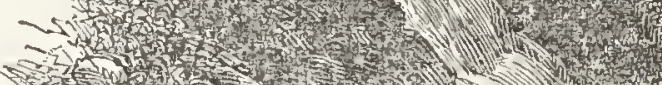
n. $7+1$. A RIFT IN THE OCIILS, NEAR MFAstrie. 
foot of Bencleuch. The glens and wooded copses behind it are full of beauty. The old ballad nevertheless assumes the supremacy of Menstrie, near the foot of Dunmyat:-

"Oh, Alva's woods are bomnie, Tillicoultry's hills are fair,

Bat when I think o' the bonnie braes o' Menstrie, It makes my heart aye sair." *

The village of Tullibody looks down upon the "bonnie braes o' Menstrie." A valley lies between, along which runs the cluar winding Devon. A bridge spans the river near Tullibody, from which a fine view is obtained of the winding Devon, the hill of Bencleuch, and the village and woods of Alva at its base. In this neighbourhood the famous adventure of James the Fifth and the Gudeman of Ballangeich occurred. On the Gudeman's visit to Stirling, the King designated him as "King of the Mruirs." The cottage in which King James took shelter lay on an eminence near Tullibody, about a mile south of the Ochils.

Tullibody seems in some way to have been connected with that mythical people the Picts. Who were the Picts or Pechs? Many have tried to unravel the story, but the result has been mere guesswork. Some say that

* Menstrie House was formerly the seat of the Earl of Stirling. It was destroyed by the Parliamentarian army during the reign of Charles I.; in return for which the clans under Montrose devoted Castle Campbell to flames and ruin in 1645.

t The name of Tullibody is said to be derived from the Celtic langrage-Tulach, a little green eminenee, and Boidich, a vow, a solemn promise. Hence Tulachboidich, the knoll of the oath. 
they occupied the Orkneys, Caithness, and Sutherland; others that they inhabited Mid-Scotland, between the West Highlands and the Lowlands north of the Forth. We hear of them at Brechin, at Galloway, and along the Picts' Wall. Some say they were Celts, others Scandinavians. The riddle is as yet quite unsolved.

The story goes that the Picts were totally defeated by King Kenneth in the neighbourhood of Tullibody, or Dunbodenum,* in the year 843, after five successive battles. It is said that the final overthrow of the I'icts took place near the village of Logie, close under Dunmyat; and others that it took place at Cambuskenneth Abbey, which "was built by David the Second on the very spot where his royal ancestor gave the final blow to the Pictish dominion."

In commemoration of the event it is said that a "Standing Stane" was first erected at Tullibody,-a usual method of distinguishing the site of a battle in ancient times. The "Standing Stane" was, however, demolished about fifty years ago, the broken fragments being found useful in mending the roads.

The Abbut of Cambuskenneth took Tullibody under his charge, whether in connection with the victory of Kenneth Macalpine over the Picts, or because the place was in his immediate vicinity, does not appear. At all events, a primitive place of worship was erected at Tullibody, which long continued to be an appendage to the wealthy Abbey of Cambuskenneth.

* From Dun Buddran, the fort of Budiran, a celebrated Celtic chicf. 
At the period of the Reformation in Scotland, when the French troops under Mary of Guise were flying westward through Iife and Clackmannan on the arrival of the English flect in the Forth, William Kirkaldy of Grange, to impede their progress, destroyed the eastern arch of Tullibody bridge.

The French, under Gencral D'Oysel, never at a loss in an emergency, unroofed the church at Tullibody for the purpose of repairing the bridge. To use the words of John Knox:- "Ye French, expert enough in sic feats, tuke downe ye roofe of a parock kirk, and made ane brig over ye water called Devon, and sae they escapet and gaed to Stirling, and thereafter to Leath."

For a long time nothing was done to repair the church, after the French had unroofed it. The ancient walls fell to decay, and became covered with wild weeds. The body of the chureh was used as a burial-place. The place might have gone to utter ruin but for the Abercromby family, who own the estate of Tullibody. They

* John Knox adds--"As ye Frenche spullyed ye cuntry in their returning, ane captane or soldiour, we cannot tell, but he lad a reid clocke and a gilt murrion, entered upon a pure woman, that dwelt in ye Quhytsyid, and began to spoille. Ye pure woman offerit unto lim sic breid as sche had redy prepaisit, but he, in no ways tharewith content, wold have ye meil and a littill salt beef, quhilk ye pure woman had to sustein hir own lyif, and ye lyves of hir pure childrein ; nowther could teirs nor pitifu!l words mitigate ye mereiles man, bot he wold liave quhatsocvir he micht eary. The pure woman perceaving him so bent, and that he stoupit down in hir tub for the taking furth of sick stuff as was within it, first conpit up his heilles, so that his heid went down, and thairafter bo hirsclf, or if ony uther companic came to helpe hir, but there he onctit his unluepe lyif." 
roofed over the church, and seated it as a place of worship. They erected some fine monuments and memorials in and about it to the memory of the distinguished men of the family. Among them is a cenotaph to the distinguished Sir Ralph Abercromby, the hero of Aboukir.

Having thus described the scenery of the Ochils and the Devon, amongst which Robert Dick spent many of his early days, we proceed to relate the story of his life. 


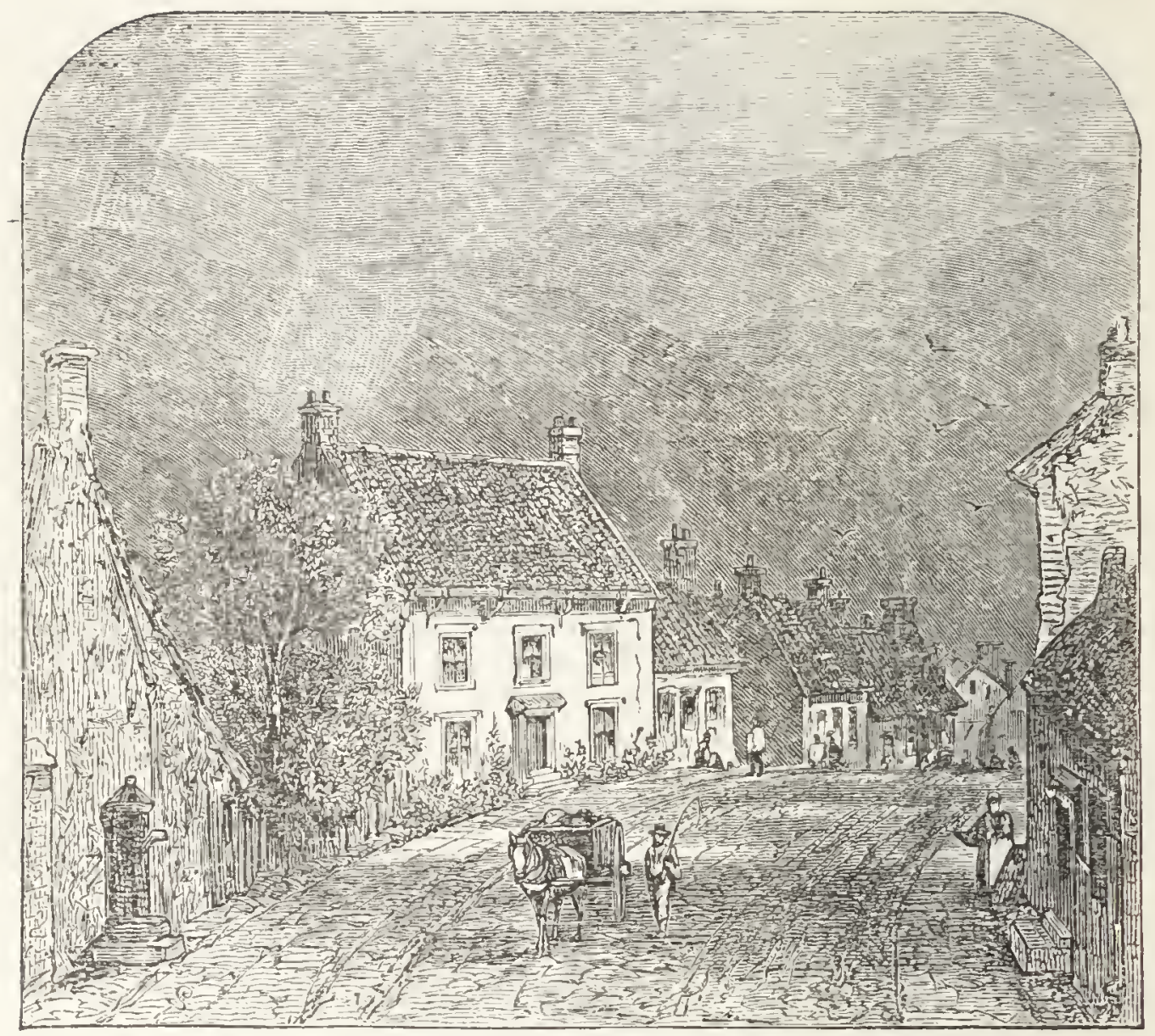

ROBERT DICK'S BIRTHPLACE.

\section{CHAPTER II.}

\section{ROBERT DICK'S BOYIIOOD.}

Robert Dick was born at Tullibody in January 1811.* He was one of four children-Agnes, Robert, Jane, and James.

Thomas Dick, his father, was an officer of excise. He was an attentive, diligent, and able man. He eventually rose to one of the highest positions in his calling. At the time when Robert Dick was horn,

* Miss Dick, his half-sister, says he "as born in 1810, though 1811 is on his tumbstone. 
it was his business to attend daily at the Cambus Brewery, close at hand.

Margaret Gilchrist was Robert Dick's mother. Very little is known of her, excepting that she was a very delicate woman, and died shortly after having given birth to her fourth child. Thomas Dick was thus left without a wife, and his children without a mother.

The house in which the Dick family lived, and in which Robert was born, is situated in the principal street of the village. It is a two-storied, red-tiled, "self-contained" house. Looking down the street from the Tron Tree, you see the Ochil hills forming the back-ground of the village; the Devon winding in the valley below.

The children, as they grew up, were sent to school. Tullibody was fortunate in its Barony School, founded and partly endowed by the Abercromby family. Thus all the children in the village were able to obtain a fair education at a moderate price; for in Scotland it is considered a disgrace if a parent, of even the meanest condition, does not send his children to school.

Mr. Macintyre was the teacher of the Barony School. He was a man of considerable attainments. Above all things, he was an enthusiastic schoolmaster. He maintained discipline, inculcated instruction, and elevated the position of his school by steady competition. He endeavoured to avoid corporal punishment, and only appealed to it as the last resource.

Robert Dick was one of his aptest scholars. He learned everything rapidly. When he had mastered 
reading, he read everything he could lay hands on. He was fond of fun and sport, and, like all strong and active boys, he sometimes got into scrapes. When he infringed the rules of the school, the master gave him a number of verses to commit to heart. But he learnt them so quickly and recited them with such ease, that the task was found of no use as a punishment, and then, on any further indiscretion being committed, the master resorted to the last extremity - the Taws!*

In a letter to Hugh Miller, Dick afterwards said, "My auld dominie used to say that I had a good memory. Every morning, in his introductory exercise, before the business of the day began, he used to pray that teacher and scholars might all lo taught, and that discipline might be followed with obedience."

Robert had a great talent for languages. He learnt Latin so quickly that his master recommended Mr. Dick to send him to college, with the object of educating him for one of the learned professions. Such was his intention, when an event occurred which prevented its being carried into effect.

This was Mr. Dick's second marriage. It occurred in 1821, when Robert was ten years old. Mr. Dick married the daughter of Mr. Knox, the brewer at Cambus, whose premises he inspected. As the excise regulations did not permit of his surveying the premises of a relative, he was removed to Dan's Burn, a hamlet at the foot of the Ochils, where he inspected the whisky distillery of

The Tares, a thick leather strap about thr se feet long, cut into tails at the end. 


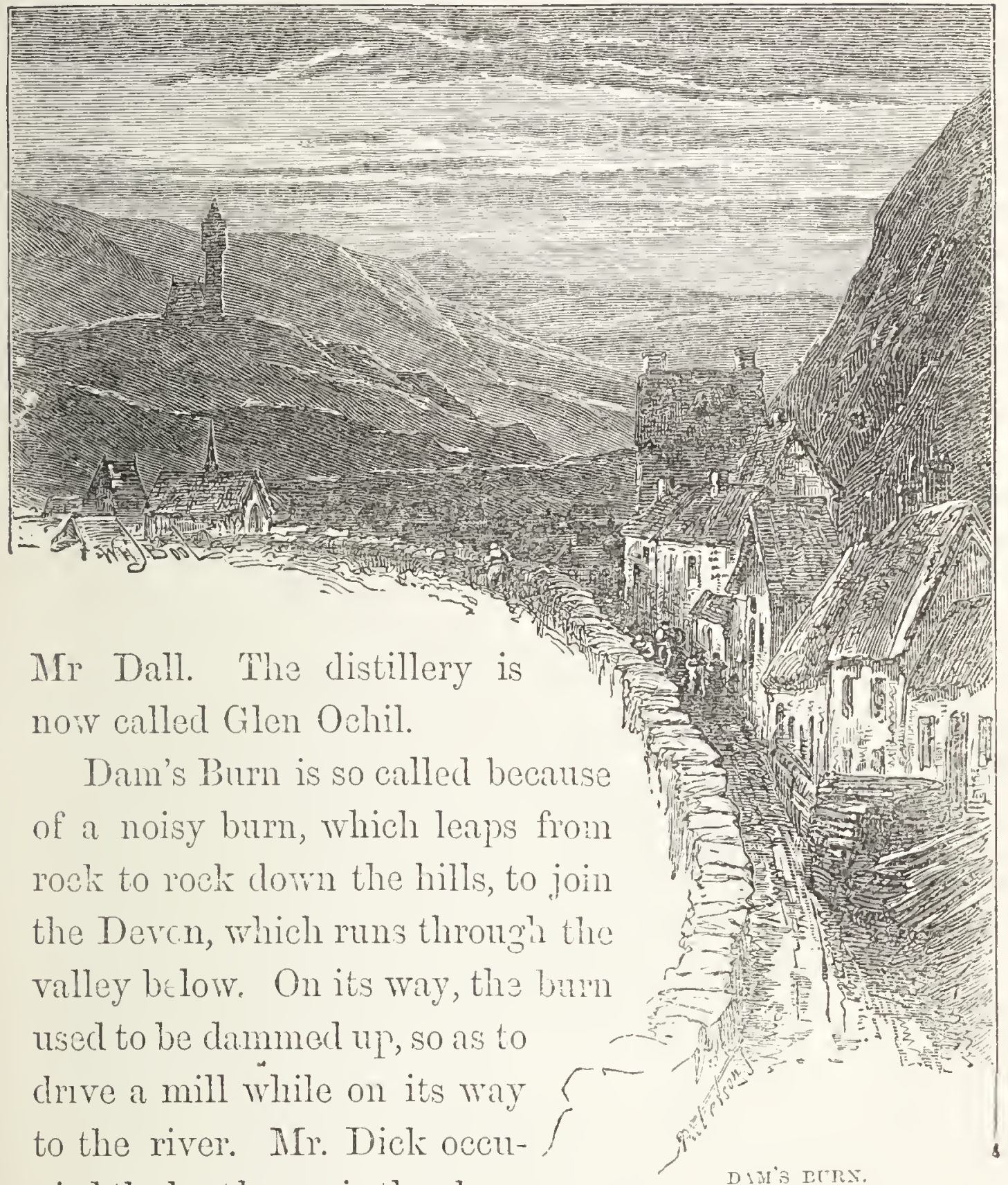
pied the besthouse in the place,

- the slated house, with its gable cnel towards the street, as shown in the ammexed cugraving. The slopes of the Ochil hills,- the Abbey Craig, on which the Wallace Monument now stands,- -and the Campsie Fells, beyond Stirling, are seen in the distance.

While at Darr's Burn, Robert Dick went to the parish school at Menstrie, a village about hall a mile westward. 
The teacher's name was Morrison. He was not equal in accomplishments to the Barony schoolmaster at Iullibody. He took to teaching because he had not limbs enough to fit him for anything else. He had only one arm. He used to mend his pens dexterously, while holding them firmly under the little stump that remainer on the other side.

Robert Dick made little progress under this master. He learned his lessons well enough, and read as many books as he could find or borrow. But he had a great compensation at Dam's Burn for his want of school learning. It was at Dam's Burn that he imbibed his love of Nature. The green Ochils rose right behind his father's house. By stepping into the back-green, he could at once ascend the heights. He could ramble up the burns, and in the sheltered corners, behind the rocks, find many precious flowers and plants.

The boy who plays about a mountain side, or among the clefts of the hills, finds many things to amuse him. In spring time there are the birds; in summer there are the plants and flowers; and in winter there are the icicles hanging down the ledges of the rocks. Robert also found out a variety of stones among the hills,-the felspar, porphyry, and greenstones, which are common in the Ochils. He wondered at the difference between them,--made a collection of them, which he treasured at a dike-side, behind his father's house,and tried to find out the canse of the difference between one stone and another.

This climbing of the Ochils led him into difficuities. 
And this leads us to a point in the history of Robert Dick's life which cannot be omitted, inasmuch as it coloured his whole future life. The years of childhood and boylood are, as it were, a sort of prophetic recital of the years of manhood. They constitute the little stage on which, with puny powers, we unconsciously rehearse the scenes of after life.

The boy has in him the seeds of good and the seeds of evil. Which will prove the stronger? No one can tell. But, to a large extent, it depends upon the effects of love and sympathy at home. The presence of these may call into life the best growths of the soul, and the absence of them may raise up the noxious miasmas that poison the whole human heart.

It will be remembered, that when Thomas Dick removed to Dam's Burn, he married again. Other children were soon added to the household. Then the feelings of the step-mother came into play. It requires great tact and temper to manage a family in which there are two elements,- the children of the first mother, and the children of the second.

The new Mrs. Dick was a good wife and an excellent mother, so far as her own children were concerned. But she did not get on well with her husband's children by his first wife. Perhaps they regarded her as an intruder in the household; and where her own children were concerned, she naturally regarded them with preference.

Nor were her husband's attentions to his children by lis first wife at all to her taste. What was done for them cvoked many a pang of maternal jealousy. Mother-like, 
human-like, she could not but regard these young things as intruders upon her own children's standing room. All that was given to them was so much taken from her own offspring.

Hence arose family difficulties in the household. Robert stayed out, rather than remain indoors. He wandered about among the hills. He wore out his shoes. To prevent him going out, his step-mother hid them. Still Robert climbed the hills, and came home with bleeding feet. He was punished for his misdoings, and commanded to stay at home. This did not hinder him from going out again. He would wander along the Devon looking for birds' nests. This was as bad as climbing the Ochils, and he was again thrashed with a stick.

It was the same with the other step-children. James, the youngest son of the first wife, struck back. Poor fellow! He was pommelled so hard that he could scarcely stand. Was he a "dour," hard, perverse boy? Very likely. He had no mother's affection to bear him up. Robert Dick never complained. He took his thrashings without grumbling. Still he went on in his old way, though he could not but feel the hollowness of his new motherhood.

At last the children were got out of the house, Instead of being sent to college (as had been his father's intention), Robert was sent to Tullibody, where he was apprenticed to a baker. Shortly after, James, the youngest boy, went to sea; and Agnes, the eldest, went to be a servant at Edinburgh. 
Of course this was a very bad training for an intelligent, high-spirited boy. It was not calculated to liberate the ideal human being which lies concealed in every child. It was, on the contrary, calculated to sour the boy's nature, and to thwart his temperament at every point. It threw a dark shadow along the whole of his future life.

Long afterwards, in speaking to Charles Peach about his early struggles, he said-" All my naturally buoyant, youthful spirits were broken. To this day I feel the effects. I cannot shake them off. It is this that still makes me shrink from the world." It will be necessary to bear these facts in mind while reading the story of Robert Dick's after life.

There were, however, two or three things that Robert had already learnt. He was educated, as Scotch boys usually are, at the parish school. He had leamt reading, writing, arithmetic, and a little Latin. It did not amount to much, but it was the beginning of a great deal. The rest of his education he owed to himself. As Stone, the son of the Duke of Argyll's gardener, said, "One needs only to linow the twenty-six letters of the alphabet to be able to learn everything else that one wishes."

Another thing that he learnt during this trying period of his life, was self-control. Though treated with capricious restraint, he never retorted. He bore uncomplainingly all that was laid upon him. Though strong. and spirited, he was a good-natured boy. He felt that, under the circumstances, the ill-treatment of his step- 
mother was a thing that he must bear; and he bore it uncomplainingly, looking forward to better times.

There are compensations in all things. He was happy to leave home. It was a pleasure to him to find that there was some other roof under which he could live in comparative comfort.

But he never forgot the circumstances under which he had left home. When he afterwards heard of a neighbour losing his wife, he said, "Ah! a sad thing for the bairns! Had my own mother been alive I would never have been a baker!" 


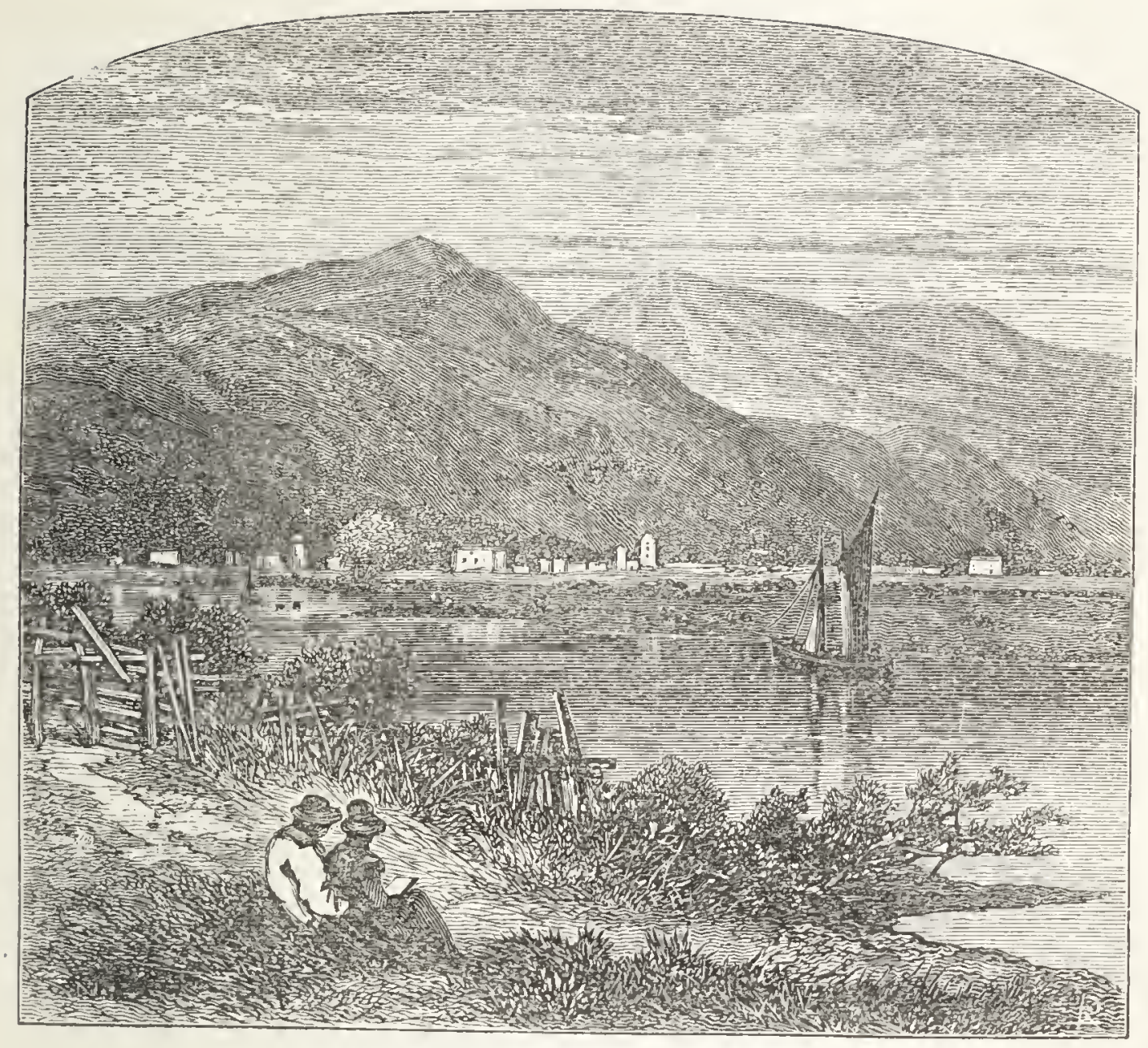

DUNMYAT, FROM CAMBUSKLNNETH.

\section{CHAPTER III.}

ROBERT DICK APPRENTICED.

Ropert Dick was apprenticel to Mr. Aikman, a baker in Tullibody, when he was thirteen years old. Mr. Aikman had a large business, and supplied bread to people in the neighbouring villages as far as the Buidge of Allan.

The life of a baker is by no means interesting. One day is like another. The baker is up in the. morning at three or four. The oven fire is kindled first. The 
flour is mixed with yeast and salt and water, laboriously kneaded together. The sponge is then set in some warm place. The dough begins to rise. After mingling with more flour, and thorough lineading, the mass is weighed into lumps of the proper size, which are shaped into loaves and "bricks," or into "baps," pemny and halfpenny. This is the batch, which, after a short time, is placed in the oven until it is properly baked and ready to be taken out. The bread is then sold or delivered to the customers. When delivered out of doors, the bread is placed on a flat baker's basket, and carried on the head from place to place.

Robert Dick got up first and lindled the fire, so as to heat the oven preparatory to the batch being put in. ITis nephew, Mr. Alexander of Dunfermline, says "he got up at three in the morning, and worked and drudged until seven and eight, and sometimes nine o'clock at night."

As he grew older, and was strong enough to carry the basket on his head, he was sent about to deliver the bread in the neighbouring villages. He was sent to Menstric, to Lipney on the Ochils, to Blairlogie at the foot of Dunmyat, and farther westward to the Bridge of Allan, about six miles from Tullibody.

The afternoons on which he delivered the bread were a great pleasure to Dick. He had an opportunity for observing nature, which had charms for him in all its moods. When he went up the hills to Lipney, he wandered on his return through Menstrie Glen. He watched the growth of the plants. He knew them indiridually, one 
from the other. He began to detect the differences between them, though he then knew little about orders, classes, and genera. When the hazel-nuts were ripe he gathered them and brought loads of them home for the enjoyment of his master's bairns. They all had a great love for the 'prentice Robert.

He must also, in course of time, have obtained some special acquaintance with botany. At all events, he inquired, many years after, about some particular plants which he had observed during his residence at Inam's Burn and Tullibody. "Send me," he said to his eldest sister, "a twig with the blossom and some leaves, from the Tron Tree in Tullibody." The Tron Tree is a lime tree standing nearly opposite the house in which Robert was born.

"Send me also," he said, " a specimen of the wild geranium, which you will find on the old road close by the foot of the hills between Menstrie and Alva. I also want a water-plant [describing it] which grows in the river Devon." The two former were sent to him, but the water-plant could not be found.

Robert's apprenticeship lasted for three years and a half. He got no wages-only his meals and his bed. He occupied a small room over the bakehouse. His father had still to clothe him, and his washing was done at home. On Saturdays he went with his "duds" to Dam's Burn. But either soap was scarce, or good-will was wanting. His step-mother would not give him clean stockings except once a fortnight. His sister Agnes used to accompany him hone to Tullibody in the 
evening, and at the Ailmans' door she exchanged stockings with him, promising to have his own well darned and washed by the following Sunday.

The day of rest was a day of pleasure to him. He did not care to stay within doors. He had shoes now, and could wander up the linls to the top of Dunmyat or Bencleuch, and see the glorious prospect of the country below; the windings of the Devon, the windings of the Forth, and the country far away, from the castle of Stirling on the one hand to the castle of Edinburgh on the other.

Dick continued to be a great reader. He read every book that he could lay his hands on. Popular books were not so common then as they are now. But he contrived to borrow some volumes of the old Elinburgh Encyclopedia, and this gave him an insight into science. It helped him in his knowledge of botany. He could now find out for himself the names of the plants; and he even began to make a collection. It could only have been a small one, for his time was principally occupied by labour. Yet, with a thirst for linowledge, and a determination to obtain it, a great deal may be accomplished in even the liumblest strtion.

In 1826, Mr. Dick was advanced to the office of supervisor of excise, and removed to Thurso. Robert was then left to himself in Tullibody. He had still two years more to serve. One day followed another in the usual round of daily toil. The toil was, however, mingled with pleasure, and he walked through the coimtry with his bread basket, and watched Nature with ever-increasing delight. 
He made no acquaintances. The Aikmans say "that he was very kind to his master's children-that he was constantly bringing them flowers from the fields, or nuts from the glens, or anything curious or interesting which he had picked up in the course of his joumeys." He occupied a little of his time in bird-stuffing. He stuffed a hare, which he called "a tinkler's lion." It need scarcely be said that the children were very fond of their father's 'prentice.

At length his time was out. He was only seventeen. But he had to leave Tullibody, and try to find work as a journeyman. He bundled up his clothes and set out for Alloa, where he caught the boat for Leith. Ile never saw Tullibody again, though he long remembered it. His father and mother were buried in the churchyard there; and he could not help having a longing affection for the place. But he could never spare money enough to revisit the place of his birth.

Long after, when writing to his brother-in-law, he said,--" And ye have been up to Alloa. Well, I do believe that is a bonnie country, altho' I fancy it is not in any sense the poor man's country. Nothing but mon of money there; though fient a hair did I core for their grandeur while I lived there. The hills and wooks, and freedom to run upon them and through them, was all I cared about.

"What though, like commoners of air, We wander out we know not where,

But either louse or liall?

Yet Nature's charms, the hills and woods, The sweeping vales, and foaming floods, Are free alike to all.' 
I daresay I might pick up a plant or a stone with very different feelings from those I felt in the days of old. But let them go! There is no use in repining."

Again, when writing to a fellow botanist, who doubted whether Digitalis purpurec was a native of Caithness, he said, "I have seen more of the plant in Caithmess than I ever saw about Stirling, Alloa, or on the Ochil hills,--more than I ever saw in the woods of Tullibody."

Robert Dick found a journeyman's situation at Leith, where he remained for six months. His life there was composed of the usual round of getting up early in the morning, kneading, baking, and going about the streets with his basket on his head, delivering bread to the customers. It was a lonely life; and the more lonely, as he was far away from Nature and the hills that he loved.

From Leith he went to Glasgow, and afterwards to Greenock. Ile was a journeyman baker for about three years. His wages were small; his labour was heavy; and he did not find that he was making much progress. He continued to correspond with his father, and told him of his position. The father said, "Come to Thurso, and set up a baker's shop here." There were then only three bakers' shops in the whole county of Caithness,one at Thurso, one at Castleton, and another at Wick.

In that remote district "baker's bread" had scarcely come into fashion. The people there liver chiefly on oatmeal and bere," - oatmeal porridge and cakes, and

* Bere or bar (Norwegian) a commoner kind of barley.

"I sing the juice Scotch bear can make us."-Duris. 
barley bannocks, with plenty of milk. Upon this fare men and women grew up strong and healthy. Many of them only got a baker's loaf for "the Sabbath."

Robert Dick took his father's advice. He went almost to the world's end to set up his trade. He arrived at Thurso in the summer of 1830 , when he was about twenty years old. A shop was taken in Wilson's Lane, nearly opposite his father's house. An oven had to be added to the premises before the business could be begun; and in the meantime Robert surveyed the shore along Thurso Bay.

Thurso is within sight of Orkney, the Ultima Thule of the Romans. It is the northernmost town in Great Britain. John o' Groat's - the Land's End of Scotland - is farther to the east. It consists of only a few green mounds, indicating where John o' Groat's House once stood.**

Thurso is situated at the southern end of Thurso Bay, at the mouth of the Thurso river,- - the most productive salmon river in Scotland. The fish, after feeding and cleaning themselves in the Pentland Firth, make for the fresh water. The first river they come to is the Thurso, up which they swim in droves.

Thurso Bay, whether in fair or foul weather, is a grand sight. On the eastern side, the upright cliffs of Dunnet Head run far to the northward, forming the most northerly point of the Scottish mainland. On the

* A very comfortable hotel has recently been erected close to the site of John o' Groat's. Many pleasure parties come from Wick and Thurso to spend the day there, and pick up the John o' Groat's buckies. 
west, a high crest of land juts out into the sea, forming at its extremity the bold precipitous rocks of Holborn Head. Looking out of the bay you see the Orlnney Islands in the distance, the Old Man of Hoy standing up at its western promontory. At sunset the light glints along the ishand, showing the bold prominences and depressions in the red sandstone cliffs. Out into the ocean the distant sails of passing ships are seen against the sky, white as a gull's wing.

The long swelling waves of the Atlantic come rolling in upon the beach. The noise of their breaking in stormy weather is like thunder. From Thurso they are seen dashing over the Holborn Head, though some two hundred feet high; and the cliffs beyond Dunnet Eay are hid in spray.

Robert Dick was delighted with the sen in all its aspects. The sea opens many a mind. The sea is the most wonderful thing a child can see; and it long continues to fill the thoughtful mind with astonishment. The sea-shore on the westorn coast is full of strange sights. There is mothing but sea between Thurso and the coasts of Labrador.

The wash of the ocean comes by the Gulf Stream round the western coasts of Scotland, and along the northern coasts of Norway. Hence the bits of driftwood, the tropical sea-weed, and the tropical nuts, thrown upon the shore at Thurso.

In the same way, bits of mahogany are sometimes carried by the ocean current from Honduras or the Bay of Mexico, and thrown upon the shore on the northern 
most coasts of Norway. One evening, while walking along the beach near Thurso, Robert Dick took up a singular-looking nut, which he examined. He remarked to the friend who accompanied him, "That has been brought by the occan current and the prevailing winds all the way from one of the West Indian Islands. How strange that we should find it here!"

Robert Dick always admired the magninicent sea pictures of Thurso Bay-its waves that gently rocked or wildly raged. He enjoyed the salt-laden breath of the sea wind; and even the cries of the sea birds. Here is his description of the sea-mew: "Ha ga tirwa!' How strange and uncouth! How very unnatural the cry secmed. It was only the cry of a sea birl. It was within sight of the ocean. There had been a storm. It was over, but the waves in long rolling breakers dashed themselves in a rage on the sandy shore, and then were quiet. But quiet only for a moment. ' $\mathrm{Ha}$ ga tirra!' Restless and unwearied, another and another long ware followed and burst into spray. And thus it has ever been 'since evening was, and morning was.' It was then evening, the stars began to twinkle; and after a little the full moon rose. But still "IIa ga tirwa!"

But before procceding with Robert Dick's history, it is necessary that we should give a short account of the county of Caithness, over the whole of which he afterwards wandered in search of the botany, as well as of the geological formation of the district. 


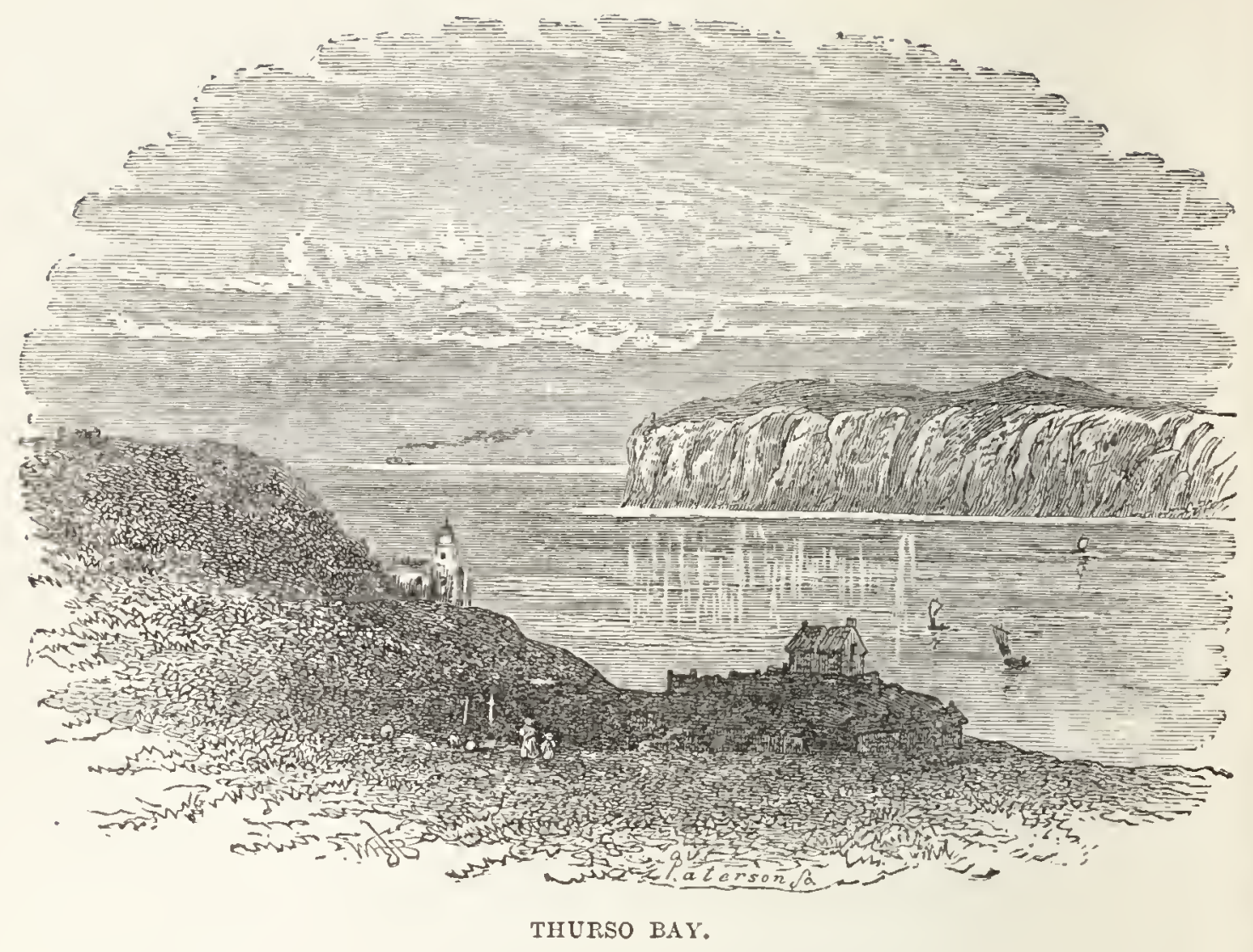

\section{CHAPTER IV.}

\section{CAITHNESS.}

Tre name of Caithness is derived from the old Norse. It indicates the ness, naze, or nose of Cattey.* Many of the headlands are also denominated ness, from Brim's Ness to the west of Thurso, to Noss Head north of Wick. Indeed, the same word is applied to headlands along the east coast of Scotland and England-from Tarbat Ness in Ross to Dungeness in Kent. The same word is applied to the Naze in Norway and in Essex, and to

* Caithmess, supposed to be the pemmsula of the Catti, a tribe celebrated by Tacitus in lis account of the Low German tribes.-TAcrTes, C. xxx. Germanio,-or perhaps from the Ugrian (Lapp) "Ketje"-an end or cxiremity.-J. Taylor. 


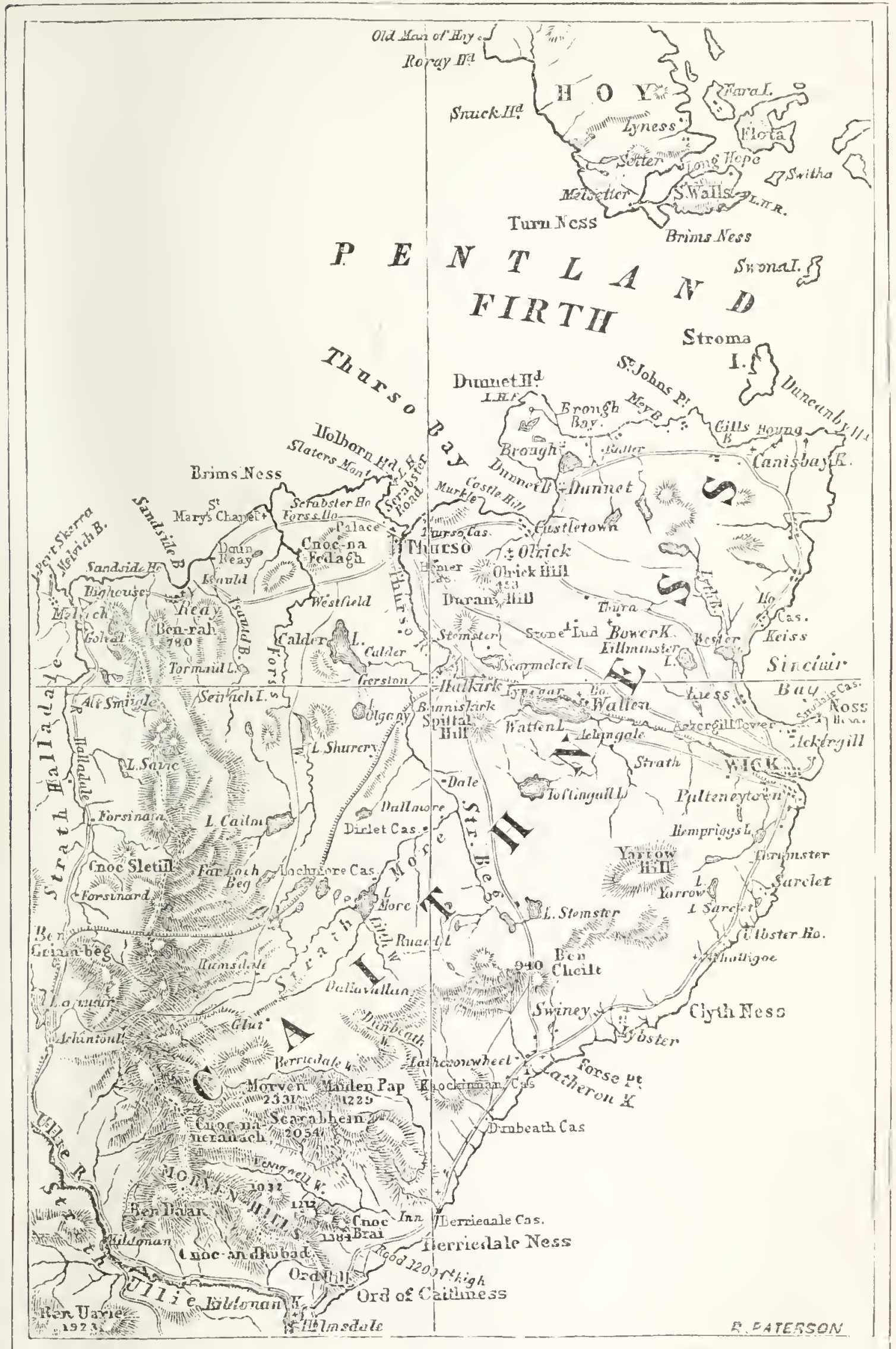

MAP OF CAITINYESS. 

Cape Gris Nez (Gray Nose) near Calais. It usually indicates a headland which the Scandinavians have named, or near which they have settled.

Caithness seems to have been almost entirely Scandinavian. The creeks or bays in which the Norsemen archored, or where they ran their boats ashore, are called by Norwegian names, from Wick, the greatest fishing station in the world, to Freswick, Sleswick, Dwarwick, and such like inlets.

The Grels seem to have been pushed inland towards the hilly country of Sutherland, while the Scandinavians occupied the low-lying ground along the const. Almost every farm steading is called by a Scandinavian name. Hence Scrabster, Lybster, Seister, Thurster, Ulbster, and such like-the word ster being from "saetr," the Scandinavian word for farm. Dahls, or dales, penetrate the country to the southward, though the Celtic word Strath is still preserved. Hence Strath Halladale and Strath Helmsdale in Sutherlandshire. North of that region, the rivers are called forss or water. Worsaae derives the name of Thurso from Thor the pagan god, and a a river. Hence Thorsa, or Thor's river.

The people also resemble their progenitors. The fair hair, blue eyes, and tall figures of the Scandinavians are still preserved throughout the ccunty,-in contradistinction to the small size, the dark hair, the swarthy skin, and the black or steely-blue eyes of the Celts, to the south and west of Scotland.

All the firths, or inlets of the sea, are known by Norse names. The Pentland Firth, which runs between the 
north coast of Caithness and the Orkneys, was in old Norse called the Petland Fiord. Here we have the mythical Picts again. Bleau, in his Geographical Atlas, says that the Picts, when defeated by the Scots, fled to Duncansby, from whence they crossed to Orkney. But, meeting with resistance by the natives, they were forced to returu. On their way back to Caithness, they all perished in the firth; from which catastrophe it was ever after called the Pictland or Pentland Firth.

IIeavy currents run through the Firth. The tide runs at the rate of ten miles an hour. A full-rigged ship, with her sails set and a favourable rvind, is sometimes driven back by the tide. This I have seen when journering along the shores of the Firth. Sonietimes it is whirled round amidst the eddying currents. Where the currents of the Atlantic Ocean and the North Sea meet, the water is chumed and eddied about as in a maelstrom. At the east end of the Firth is the island of Stroma, which in old Norse means "the island in the current." The poprlation of the island is of pure Norwegian descent; the men being excellent sailors and boatmen.

Not far from this island, and in siglit of John o' Groat's, are the two Pentland Skerries, commanding the eastern entrance to the Firth. They were originally called Petland Skjaere. The largest skerry contains two lighthouses, one higher than the other, to be a surer guide to the mariner.

During the equinoctial gales, the wind sweeps across the county with great fury. It is scarcely possible to hold one's fee's. Cattle are blown down, and trees are 
blown away. The thatched roofs of the cottages are held down by strong straw ropes with heavy stones hanging at their ends; otherwise the roofs would be blown away, as well as the cottages themselves.

It is scarcely possible to grow a tree in the northern part of the county. Hedges are almost unknown. Instead of hedges, the fields are separated from each other by Caithmess flags set on end. To one accustomed to the beautiful woods and hedgerows of the south, the cheerlessness of Caithness scenery may well be imagined. Robert Chambers said of the county_- "The appearance of Caithness is frightful, and productive of melancholy feelings." "It is only a great morass," says another writer; "the climate is unfavourable; the stormy winds are always blowing across it; mists suddenly come on, and the air is always damp."

A desperate effort has been made to grow trees at Barrogill Castle, within sight of the Pentland Firth. A wood surrounds the east side of the castle. The trees are planted thick, and they are protected by a high wall. But at the point at which the wall ends, the tops of the trees are sharply cut away as if by a scythe. They are chilled and eaten down by the sea-drift.

The best wood in the northern part of the county is at Castlehill, where the imported trees are protected by rising grounds on all sides. The only tree that thrives in Caithness is the common bourtree or elder. The trembling poplar, the white birch, and the hazel, are also occasionally found in sheltered places.

But though the county of Caithness is for the most 
part flat and cheerless, it is redeemed from monotony by its glorious coast scenery. On the east, as well as on the west, the rocks jut out into the ocean in stupendous cliffs. "When the stormy winds do blow" is the time to see the wonders of the north-at Duncansby Head, at Dunnet Head, at Holborn Head, at Noss Head, and, indeed, all round the coast. At Wick Bay, only a few years ago, a tremendous storm from the east dashed to pieces the new breakwater, lifting up stones of tons weight and dashing them on the beach,- - thus setting at defiance the skill and ingenuity of the engineer who had built it.

Duncansby Head is also exposed to the full fury of the North Sea. It is a continuous precipice about two miles in extent, and of a semicircular shape. It is remarkable for its stupendous boldness, and the wild and striking appearance of the chasms and goes by which it is indented. In front of the cliff are three Stacks, which have been washed round by successive storms, and stand out bare and red several hundred yards from the mainland. The cliff consists principally of old red sandstone, and partly of Caithness slate.

The huge, long, white-crested billows, lashed into fury by the storm, chase each other up the beach, and burst with astounding force. At high tide, they dash up the cliffs and rush over the summit into the mainland. From thence they run down over the inland slopes, into a rivulet which joins the Pentland Firth near John o' Groat's. From the summit of the cliff a fine view is obtained of the Skerries at the month of the Firth, of 
Stroma, the island in the current, and of the Orkney Islands as far as the bold headland of Hoy.

Along the east coast, numberless castles are built upon the cliffs. They are mostly in ruins. Many of them are prehistoric. Wick Castle, Girnigo Castle, and Keiss Castle, are the oldest. No one knows who built them. Most probably they are the strongholds of the Scandinavian chiefs, who, at some unknown period, took possession of the lowland part of the county.

The castle of Al-Wick-or, as it is usually called, the Auld Man of Wick-seems to be one of the most ancient. It consists of a grim-looking tower or keep of the rudest masonry, perforated here and there with arrow-slits. It is three stories high; but entirely roofless and floorless. It is surrounded by an outer wall, within which are the ruins of some old houses. A deep broad moat defends it on the land side. At present, it forms an excellent landmark to vessels approaching that part of the coast.

Girnigo Castle, situated on the promontory of Noss Head, is also very old. Castle Sinclair, which was added to it, has a history, which Girnigo has not. But the old builders were so much better than the new ones, that while Castle Sinclair has fallen to ruins, Girnigo Castle stands as firmly as it did at the time at which it was built.

The constantly rolling sea, ever for ever, washes itself against the rocks, grinding away the softest parts. The red sandstone goes first, leaving long hollows amongst the slates, through which the sea drives inland. In stormy weather, the waves wash in with 


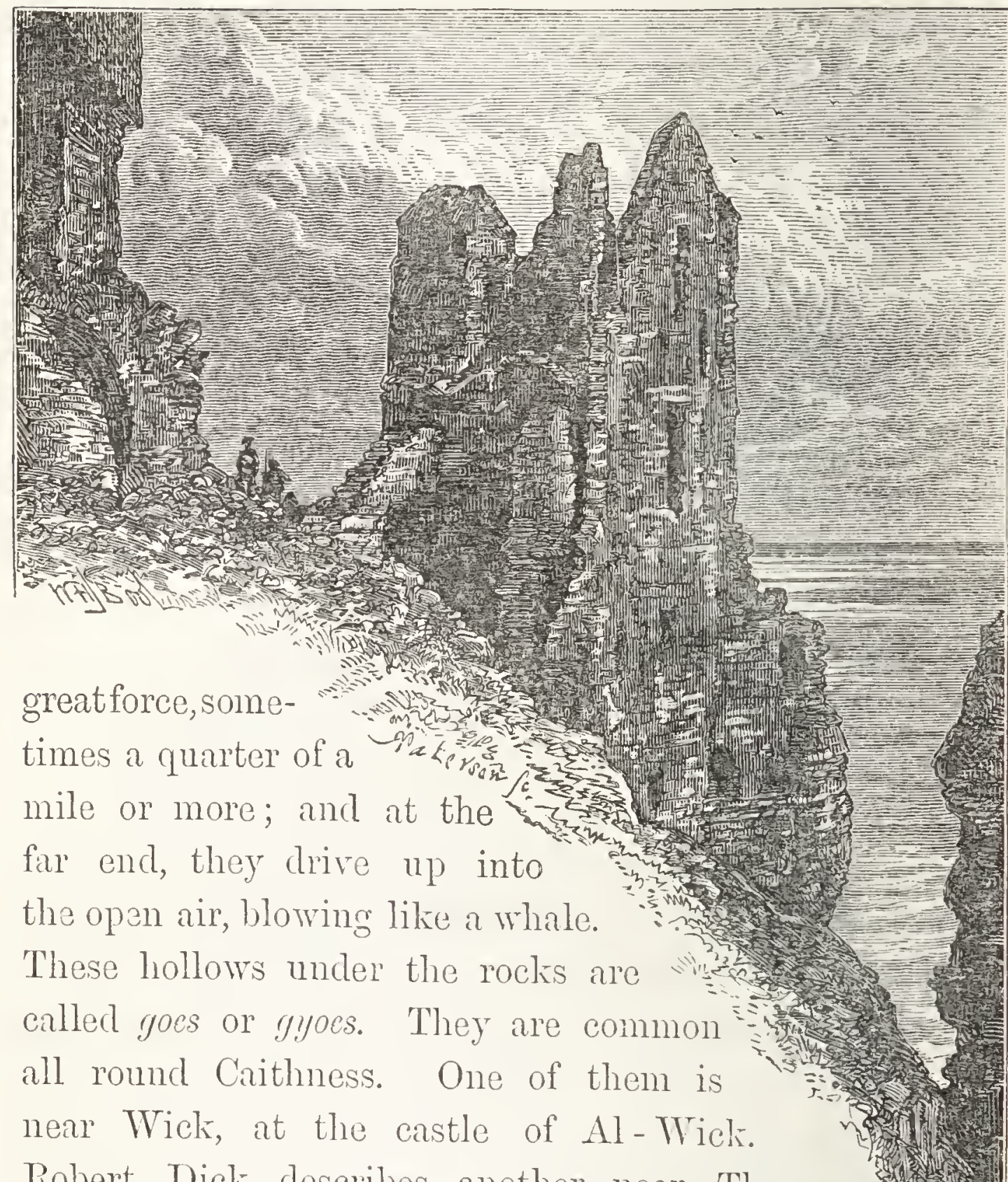
Robert Dick describes another near Thurso, which will be found referred to in a future part of the story.

From the northern part of Caithness, where the ground is comparatively flat inland, and full of lochs from Thurso to Wick, the land gradually ascends, until we find hills and then mountains close upon the borders of Sutherland. Morren, Maiden Pap, 
and Skerry Ben, form part of a range of mountains, extending from Sandside Bay on the north, to Helmsdale on the south. Morren is the great mountain of Caithness. It is 2331 feet high. It is regarded as the great weather-glass of the county. When the mist gathers about its base, rain is sure to follow; but when the mist ascends to the top and disperses, leaving the majestic outline of the mountain exposed to view, then the weather will be fine. "During harvest especially," says a local writer, "all eyes are directed towards it; and it never deceives.

"In vision I behold tall Morven stand,

And see the morning mist distilling tears

Around his shoulders, desolate and "rand."

From what we have already stated, it will be understoud that Caithness is by no means a fertile county. Until a comparatively recent period agriculture was in a very backward state. When Pennant visited the county about a hundred years ago, he describes it as little better than "an immense morass," with here and there some fruitful spots of oats and bere, and much coarse grass.

In those places where any agriculture was carried on, the women did the work of horses. They carried the manure on their backs to the field; and did the most of the manual labour. The land could scarcely be called ploughed. The Caithness plough was onestilted. It was dragged over the ground by a yoke of oxen, driven by a woman. There were neither barns nor granaries in the county. The corn was preserved 
in the chaff in bykes, which were low stacks in the shape of bee-hives, thatched quite round.

Thurso, the chief place in Caithness, carried on a trade with Norway and Denmark, long before it began to communicate with the rest of Scotland. The sea was by far the easiest mode of transit; and all tine people along the coast were sailors. But, indeed, there was very little traffic to be carried on. The only two clusters of houses in the county were Thurso and Wick. Thurso must have been the more important place, as it not only had a church, but also a bishopthe Bishop's Palace being close at hand. Thurso was a small fishing town, and Wick contained only a few hundred inhabitants. But the fishing has long left Thurso, and gone to Wick. "The only fishing at Thurso now," said Dick, "is sillocks and sillock scrae. The salmon fishing, however, is the best in the kingdom."

There were then no roads in Caithness. The extensive hollows in the flat slaty ground were filled with morasses. There was not a single wheel-cart in the county before 1780. Crubbans were the substitutes for carts. They were wicker baskets. Two of them, hung one on each side of a pony from a wooden saddle, beneath which was a cushion of straw, carried corn, goods, and other articles. Six or seven ponies thus loaded, says Henderson in his Agricultural Survey of Caithness, might be seen going in a kind of Indian file, each tied by the halter to the other's tail, a person leading the front horse, and each of the others was pulled forward 
by the tail of the one before him. Yet traffic was carried on throughout England in the same manner, about three hundred years ago.

Caithness was behind in everything. The only geography of the county was known from Danish sources. Timothy Pont made his first map in 1608. It was shut out from the rest of Scotland by the mountainous county of Sutherland.* It was long before a road could be made to enable the people to communicate with their countrymen farther south. The only road lay along the eastern shore, among rocks and sand, which were often covered by the tide. The inland road lay over the Ord of Caithness. The Ord is a formidable pass between Sutherland and Caithness. It is situated at the eastern boundary of the two counties. There is a lofty mountain on one side of the road, and a steep precipice on the other, at the foot of which is the sea.

The Ord is the termination of a long mountain ridge, and is the brow of a steep hill overhanging the ocean. On the Sutherland side, the headland is cleft into a gorge of great depth, which runs a long way inland. The old road-before the present bridge was built over the gorge - was a mere path or shelf along the outer edge of the promontory twelve hundred feet above the sea. When

* It may seem strange to us that the extreme north-western corner of Great Britain should be called Sutherland. No inhabitants of Scotland could have bestowed so inappropriate a name. It was evidently given by a people living still farther to the north. Sutherland, in short, is the mainland to the south of the Orkney Jarldom. Here, as well as in Caithness, we find numerous Norwegian names. The barien uplands were left to the Gael.-TAYLor, Words and Places. 
the weather was stormy, it could not be passed in safety. Even in fair weather, the road was so difficult and dangerous that, when the chaise of a landed proprietor liad to pass it, a force of fifteen or twenty persons was employed to help on the carriage and horses.

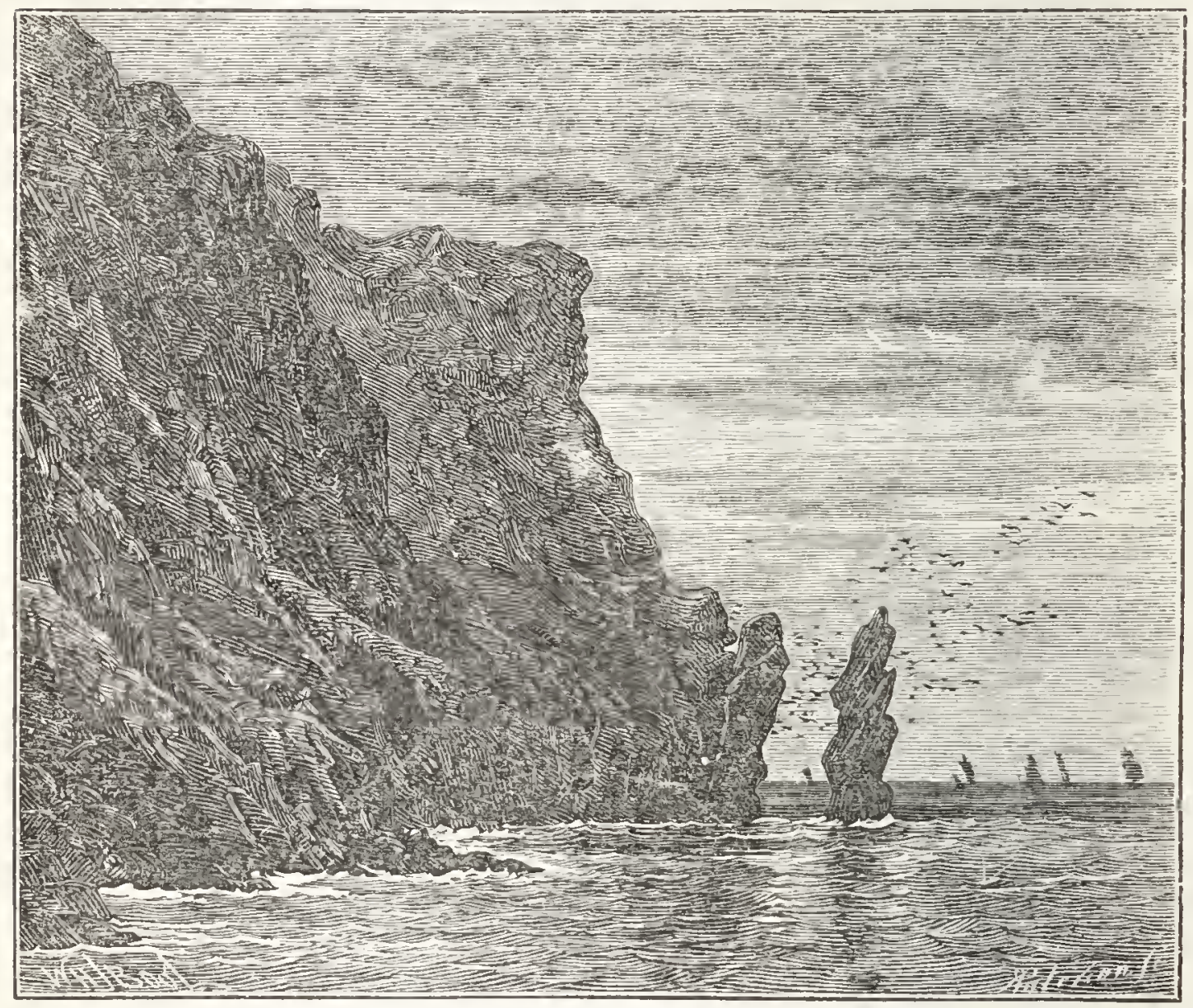

ORD OF CAITHNESS.

Pennant, who travelled into many strange places, described the pass as "infinitely more high and horrible than Penmaenmaur in Wales;" and another writer says, "that if any stumble thereupon, they are in danger of falling down a precipice into the sea at the bottom of the rock, which is very terrible to behold." The old path is still to be seen from Helmsdale. It is like a 
sheep-track winding up the steep brow of the hill, some three or four hundred feet above the rolling surge.

The road to Thurso from the Ord road was almost impassable. It was a mere horse track over the hill of Bencheilt. This road was made passable for carriages through the energy of Sir John Sinclair. The Abbé Gregoire denominated Sir John "the most indefatigable man in Europe." To him the improvement of the county of Caithness in a great measure belongs. He was born at Thurso Castle, an ancient edifice built by the sixth Earl of Caithness. It has since been pulled down to make room for a spick-and-span new castle, much less picturesque than the old one. It stood almost within sea-mark on Thurso Bay. In stormy weather, the sea spray sometimes passed over the roof. Miss Catherine Sinclair has said that fish have been caught with a line from the drawing-room window; and vessels have been wrecked so close under the turrets, that the voices of the drowning sailors have been heard.

When Sir John succeeded to his estates, three-fourths of Caithness consisted of deep peat-moss, and of hills covered with heath, or altogether naked. On arriving at his majority, he determined upon the improvement of his estates, and of the county generally. One of the first things that he did was to endeavour to make a road to Thurso over Bencheilt, in the centre of the county. He himself surveyed the road and marked out its lines. He called together twelve hundred and sixty labourers to meet him early one morning, and set them all simultaneously to work. They began at the dawn of day, $3 *$ 
and before nightfall, the sheep-track, six miles in length, was converted into a road perfectly easiy for carts and carriages. This showed what energy could accomplish.

The young laird was not satisfied with that. He formed a large number of farms on his own estate. He enclosed, drained, and reduced them to order, entirely at his own expense. He built bridges; he made roads; he introduced the best cattle; he provided the best turnip, rye-grass, and clover seeds; he enjoined upon his farmers to adopt a regular rotation of crops; and in a short time converted what had been a barren wilderness into a well-cultivated district. He enclosed on his own estate about 12,000 English acres of waste land, all of which eventually repaid the outlay. Among his other achievements, he introduced the Cheviot breed of sheep into the whole of Scotland, and thus doubled the value of the grazing grounds north of the Tweed.

Sir John tried to introduce trees at Thurso, but he found it difficult to make them grow. It was necessary to dig a hole of large dimensions through the subsoil of slaty rock, over which the tenants of the neighbouring townlands were obliged annually, for seven years, to heap a large mound of compost. And even when the trees did grow they were often blown away by the furious winds from the north and west.

Sir John even tried to introduce nightingales into Caithness! But Nature baffled his efforts. He obtained nightingales' eggs from the London bird fanciers. They were substituted for those of the robin redbreast. The 
eggs were hatched. The young nightingales soon flew about the bushes round Thurso Castle. But so soon as the summer had ended, the birds disappeared and never returned.

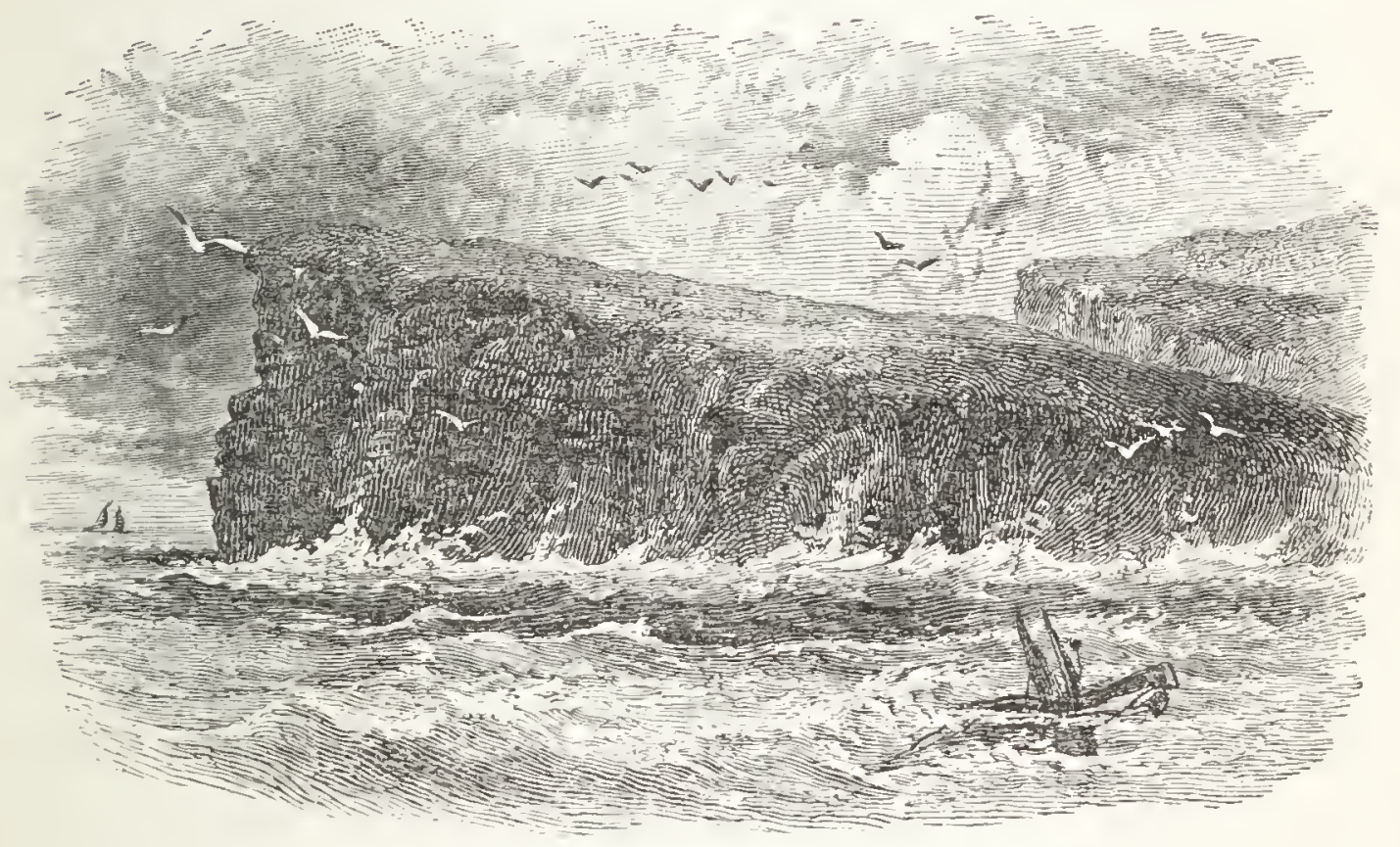

DUNCANSBY HEAD. 


\section{CHAPTER V.}

DICK BEGINS BUSINESS.

Dick began business for himself at the age of twenty. His house was in Wilson's Lane, not far from the old church. The river Thurso flows past the bottom of the lane into the sea, which is close at hand.

Mr. Smith, of Olrig, was the proprietor. After he had built a small oven behind the house and added it to the shop, Dick went over from his father's house to live there and begin his trade. The only other baker in the town was a Mr. Mackay, who was also a Baptist preacher.

There was not much trade to be done; but Robert baked a little every day, and sold his bread over the counter. When he was out, his sister Jane attended to the business. He contrived to live on very small earnings, for he had only himself to provide for. He required very little capital, for every day's batch returned the money's worth of the flour, as well as the profit to the baker.

Shortly after he began business, we find him writing to Mrr. Aikman, of Tullibody, and requesting him to send four bags of third flour, one bag of second, and one bag of best. Mr. Aikman sent the flour to Thurso. Dick 
remitted $£ 5$; but his old master said " he need not remit the balance, as he would have need of the money." In fact, three years elapsed before Robert Dick could send him the balance of the account.

When Dick's bread was sold, or while his sister Jane was watching the shop, he went out to walk along the shore. He crossed the river by the stepping-stones while the tide was out, and was at once in Thurso East. He passed under the castle and walked along the shore, sometimes as far as Dunnet Bay. He delighted to see the long rolling waves come thundering in and break upon the shore in clouds of spray. The broken surge, churned into foam, rushed rapidly up the beach with the speed of a racehorse, and then rushed rapidly back again. Even in calm weather, there is a ceaseless moaning of the surge, indicating the remnant of some storm far away in the Atlantic. When the storm comes nearer the land, the waves are stronger and louder, spending their billows on the shore. "Sometimes," says Dick, "the noise of the bay is heard booming over the town with a terrible roar."

His walks along the shore awakened in him a taste for conchology. He gathered shells by the score, and arranged them in a cabinet. He gathered up numerous things besides shells. He found a specimen of the nut of the cow-itch shrub of the West Indies,-such a nut as the brother-in-law of Columbus found floating near Madeira, which led the great navigator to infer the existence of a western continent. He found also wood, drilled by the Teredo navalis, and many specimens of 
seaweed, which had been washed by south-westerly winds from the Gulf of Mexico.*

Shells, and the mollusks which inhabit them, were not, however, sufficient to occupy his attention. He had plenty of spare time. Indeed, after his bread was baked, his work was nearly over for the day. He had to set the sponge at night, ready for next day's batch. But that occupied comparatively little time. Meanwhile he was busy with his books and his studies.

He did not make any companions. He had never felt much of the comforts of home. His social nature had been ahnost soured there. The feeling never left him, but clung to him through life. He therefore roamed about by himself along the shore, or studied by himself in his solitary household.

He reverted to his study of botany, though it might not be supposed that Thurso was a fit place for such a study. The neighbourhood was without trees, without hedges-with only flagstones dividing one field from another. Yet the seeing eye is never without proper aliment. It finds wonders in everything. Where the unseeing eyc sees nothing, it detects differences, and varieties, and classifications. But he did not as yet go

* In a specimen of fucoid, about two and a half feet in length, which I owe to the kindness of Mr. Dick of Thurso, there are stems eontinu. ous throughont, that though they ramify into from six to eight branehes in that spaee, they are quite as thick at top as at bottom. They are the remains, in all probability, of a long flexible fueoid, like those fucoids of the intertropieal seas, that, streaming slantwise in the tide, rise not unfrequently to the surfice in fifteen and twenty fathons water. -Hugit Miluer, Rembies of a Geologist. 
deeply into the subject, for he could not afford to buy books. Nevertheless, he accurately distinguished the differences of one plant from another. The further pursuit of botany was held in reserve for some future time.

About two years after Robert Dick had begun business in Thurso, his father was promoted to the office of Collector of Excise, and was removed to Haddington, where he ended his official career. His eldest sister Agnes married Mr. Alexander, and afterwards removed to Tullibody. When all the family had left, Robert was left alone-literally alone. He then took into his service Annie Mackay, a Highland woman, who served him long and faithfully to the close of his life. She was his housekeeper, and attended to the shop while Dick was on his journeys through Caithness.

Yet Robert, though alone, was not solitary. Nature was all in all to him. He enjoyed his walks along the sea-shore, and sang to himself as he went along. $\mathrm{He}$ wandered about Dunnet Head, and the rocky cliffs at Holborn Head. He saw many things that had never been seen before. He detected the scales of fish, and even the heads of fossil fish amongst the rocks.

The Clett on Holborn Head was one of his favourite spots. It is a huge isolated mass of rock, composed of dark flagstone. It is inaccessible by human foot. The rock is quite perpendicular. The surges of the ocean have washed it away from the mainland. It is screaming with sea birds. Miles away you hear the cries of the okies, or auks, which haunt it. They sit in long rows, 
"like a lot of bottles on end," as Dick described them, on the ledges of the Clett, and there they breed and bring up their young.

Here, as on the east coast, great Goes are found. The sea dashes in through the washable rocks, and drives up in clouds of vapour far inland. One of the Goes is about three miles in length. In great storms the sea deluges the whole headland, and pours back in clouds of spray. In some places the rocks are hollowed into arches by the surge, and in great gales the sea pours into them with a rush of foam. To the west of Holborn Head there is a long line of projecting headlands, and in a clear day Cape Wrath may be seen some fifty miles off. There is no land between you and the coasts of Labrador-nothing but the boundless ocean.

Dick also explored the country inland. The river Thurso was the scene of some of his future discoveries. He went far up to the castle of Dirlot, one of the oldest buildings in Caithness. He went up the hills near Thurso, from which he saw the gigantic Morven far away in the distance. He visited the Reay hills and the Shurery hills, which were afterwards his favourite botanic grounds. He was thus laying the foundations of his future knowledge, not only in botanical, but in geological science.

In the meantime he turned aside to pursue the study of entomology. Here his seeing eye was of great use to him. He worked out the natural history of the insects of Caithness from his own personal observation. Nothing escaped him. He collected no less than 256 specimens 

of beetles in nine months, - in fact, all that could be collected in Caithness. He collected 220 specimens of bees, and 240 specimens of butterflies and moths. These are all to be seen in the Thurso Museum. They are now covered with living moths, grubs, and woollice, and fast going to decay.

The boys soon found out the strange baker and his ongoings. Boys are great critics. They immediately detect nonconformity. When they saw Dick coming out of his shop in his chimney-pot hat, his swallow-tailed coat, and jean trousers, they were immediately after him. They followed him at a little distance. He went "p the green sward alongside the river; knelt down on his knees; crawled onward; and then brought his hand slap down. It was perhaps some insect that he had been long seeking for. The boys saw him take off his hat, put in the object, perhaps impaling it with a pin.

When Dick went away, the boys went up to the spot to see what he had been about. They found nothing whatever, only green grass. They did not know that Dick had found a splendid beetle. They went home to their friends, and told them what they had seen. It thus became known that he was an insect-collector. What could he want with the beetles and grubs? Surely he could not put them into his bread! Faugh! Then they whispered about that they had got a mad baker amongst them.

Dick, however, made friends of the boys. He said to them, "Whenever you can find a rare butterfly, bring it to me, and I will give you something for it. If it be in 
any way injured I will not have it." Away the boys went hunting butterflies. Sometimes they brought him in a good specimen, and he gave them sixpence for it. Sixpence was a fortune to them. It bought no end of tops, clagum, and sweeties. If the butterfly was of no use, he would take it in his hand, and let it out of the back window. "Perhaps," he said, "they may bring something valuable next time." When an unusual butterfly was brought to him, he took great care of it, saw it go through its various transformations, and noted the results.

His love of insects became known, and his curiosity about them spread throughout the neighbourhood. Country people called upon him and brought what they thought rare things. One day a man called upon him, and, standing right before him, took out of his pocket a paper lucifer box, and cautiously screwing off the lid, he said "See!" Dick looked into the box, and seizing the creature withim it by the tail, he pulled it out, and then shoved it in again. "Won't it sting?" asked the man. "Oh, no," said Dick, "it is a very humble creature,only the Green Dragon Fly : it lives by devouring small flies." "Oh!" said the man, " the country folks call it the Bull Adder, and they say that it stings." "I wouldn't have taken it by the tail if it did." "Won't you have it?" "No!" The man accordingly went away with the dragon-fly in his box.

Robert Dick's mind was athirst for knowledge at this time. He was searching for facts of all sorts. In 1835 he attended three courses of lectures delivered by Mr. 
Keir. They were upon astronomy, geology, and phrenology. He was greatly interested by the lectures. He not only heard them closely, but followed them up by study. He was particularly impressed by the lectures on astronomy. Halley's Comet was then careering through the heavens. Appearing, as it did, once in every seventy-five years, it was calculated to make a deep impression upon his thoughtful mind.

He borrowed such books on astronomy as he could obtain, and read them eagerly. He thus gathered a gencral notion of the subject; but he had no means of following it up. Telescopes were unknown at Thurso. He could only look up to the heavens, and admire and wonder. He was thus in a measure forced to inquire into such matters as lay within his own reach. He was sent back to mother earth, the secrets of which still remained to be unveiled. Hence his love for geology, and the beginning of his knowledge of the rocks of Thurso, which he first obtained from Keir's lectures.

Phrenology also excited his deep interest. The subject had been made popular throughout Scotland by the lectures and works, and probably by the personal influence, of George Combe of Edinburgh. Though the "science," as it was then called, is now nearly forgotten, it was then the subject of much discussion. George Combe started the Phrenological Magazine to advocate his views, and to maintain the principles of phrenology. He also established the Phrenological Lecture Hall and Museum, where he collected an immense number of busts of distinguished and notorious characters. 
Dick, in his enthusiasm, had his head shaved, and a cast was taken of it in plaster of Paris. He gave half a crown to a brave little girl, and induced her to have her head shaved; after which he made a cast of her head in the usual way. He sent to Edinburgh and had a phrenological cranium from O'Neil, the famous castmaker. Writing to his eldest sister, he said,_- "Mind, Nan, that when you seek for a wife for Robert, you must find one with a high forehead. None else are genuine."

But Robert could not go on looking at people's heads, and studying their development. Big heads and little heads, big bumps and little bumps, seemed a profitless study. So he condescended to study more practical subjects,-- things that lie at every man's door. He could not grasp the heavens. He could understand the planetary system; but he could not unravel the deeper meanings of the vast circle of creation. He could, however, descend to the things that lay at his feet,- - to his common mother earth, which is as full of wonders as the stars. He could pursue his first love,- - the love of flowers and plants, which he had pursued while wandering among the Ochil hills.

Dick was still a bachelor. He had a house and a shop to manage; and some of his friends advised him to marry. His old master, Mr. Aikman of Tullibody, writing to him in 1834, said :-." Mrs. Aikman sends her liind respects to you. She is happy to think that you are still a bachelor, as her family is mostly girls." Another friend at Greenock, where Dick had lived when a journeyman, wrote to him thus:--" My wife sends her 
best wishes. She hopes you will soon get married. You are losing time completely. If you wait much longer I will be speaking to you about my daughter. We are beating up. We have two married already. Come, come, look sharp!" But the fly, however skilfully thrown, could not draw the fish from his depths.

We have been informed that Robert once made a proposal of marriage to a young lady, but that she refused him. Some overtures of reconciliation were afterwards made. But he had been refused once; he would not be refused again. The disappointment only threw him back upon himself. He became more recluse, solitary, and companionless, than before. He was satisfied to remain unmarried, with Annie Mackay as his servant and housekeeper.

Among the things which occupied Dick's attention, was a mechanical method which he proposed for working up his biscuit, instead of using the baker's rail. For it must be known that he was the best biscuit-maker in Thurso. He had brought this art from Tullibody. Besides, his master sent him the proper receipts for the different kinds of biscuit and "parlyment." In making biscuit, the practice is to work the dough in the trough; the baker sitting on a rail, bumping the stuff up and down in a radiating manner. Dick thought this might as well be done by machinery. He got a mechanic to help him to perfect the machine; but though it was completed, it was not used. His trade was not great; and he found that his own hands were amply sufficient for the purpose of making his daily bread. 


\section{CHAPTER VI.}

BOTANICAL WANDERINGS.

ROBERT Dick proceeded with his study of natural science. From conchology he went on to entomology and botany. He gathered insects while he collected plants. They both lay in the same beat. After his bread was baked in the morning and ready for sale, he left the shop to the care of his housekeeper, and went out upon a search. Or, he would take a journey to the moors and mountains, and return home at night to prepare for the next day's baking.

He began to make liis entomological collection about the year 1836, when he was about twenty-five years old. He worked so hard at the subject, and made so many excursions through the country, that in about nine months he had collected nearly all the insect tribes that Caithness contained. He spent nearly every moment that he could spare until he thought he had exhausted the field.

He worked out the subject from his own personal observation. He was one of those men who would not take anything for granted. Books were an essential end; but his knowledge was not founded on books, but on Nature. Me must inquire, search, and observe for 
himself. He was not satisfied with the observations of others. He must get at the actual facts. He must himself verify everything stated in books.

He was not satisfied with the common opinion as to the species or genus to which any individual of the insect world belonged. He tested and tried everything: by the touchstone of science and careful observation. If he had any doubts about an insect, from a gnat to a dragon-fly, he would search out the grub, watch the process of its development from the larva and chrysalis state, until the fly emerged before him in unquestionable identity. It will thus be observed that he was from the first imbued with the true scientific animus; and in the same spirit he continued to find out and discover the true workings of Nature.

The Thurso people did not quite understand the proceedings of their young baker. He made good bread, and his biscuits were the best in the town. But he was sometimes seen coming back from the country bespattered with mud,--perhaps after a forty or fifty miles' journey on the moors in search of specimens. What were they to make of this extraordinary conduct? It could have no connection with baking. What could he have been doing during these long journeys?

He was now doing fairly in business. He was not yet distracted by the competition that afterwards ruined him. His wants were very small. He had only himself and his housekeeper to provide for. He was accordingly able to save money, and with his surplus capital he bought books. 
"How painfully, how slowly," he once said in a letter to Hugh Miller, "man accumulates knowledge! How easily, how quickly, it escapes and is gone! Blessings on the noble art of printing, under the shadow of whose dominion, thoughts, words, and deeds, are piled up like the proliferous corn of old in the storehouses of Pharaoh!"

Dick was now buying his flour from a merchant in Leith. He requests the merchant to send him books as well as flour. The books were purchased, packed in paper in the centre of the bags, and despatclicel to Thurso, by way of Aberdeen, Wick, and the Pentland Firth. We find him thus receiving the Gardoncr's Dictionary, the Naturalist's Magazine, and the Florigraphia Britannica. He also directs the flour merchant to buy him a microscope, and to send it him as soon as possible. His correspondent says, "I have at length bought for you the long-wished-for microscope. It is a very powerful one. I hope you will find yourself amply rewarded for your time and expense." The microscope was despatched in July 1835, and it reached Dick in safety. He found that, in the course of his investigations into the minutix of objects, he could not do without the microscope.

The flour merchant afterwards sent Dick numerous volumes of the N'aturalist's Library, and bought for him a copy of Hogarth's Works,- the large edition, with the original plates restored. We find, from the bill of lading accompanying the flour and the rolume, that its binding cost Dick two guineas. Other books, relating 
principally to botany, conchology, and geology, shortly followed. Sometimes a phrenological cast from O'Neil was imbedded in the flour. We find, from the communications that passed between the correspondents, that Dick paid his accounts promptly,-usually within a fortnight after the delivery of the flour.

When the books arrived at Thurso, and were unearthed from the flour, Dick set to work and devoured them. For Dick was a great reader, almost a forocious reader. He read everything about air, earth, sea, and heaven, as the multitude of books collected by him sufficiently indicate. He had plenty of leisure. When his bread was baked, and ready for sale, he had nothing else to do for the day but read and wander. When the weather was wet and stormy, as it often was, he read, drew, and wrote letters to far-away friends. For he had many correspondents, as the following pages will show.

When the weather was fine, he set out on his walks, along the shore, or up the country, sometimes as far as Morven. "Many is the walk," says one of his old acquaintances, "which I have enjoyed in his company on the sea-beach near Thurso Castle. I was once with him, when I found a new shell, and it was truly delightful to hear him explain its history and habits, as if it had been his next-door neighbour, and he had known the tiny thing all his life long. How kindly and meekly he spoke, and how ready he was for a joke; and what a keen perception he had of the ridiculous in everything that crossed his observation. The same night we also 
found a curious sort of nut, which he told me had been carried by the ocean currents and prevailing winds all the way from the West Indies, and was cast up on the beach just below Thurso Castle."

"On another occasion," says the same writer, "I walked with him on a botanical excursion, as far as I

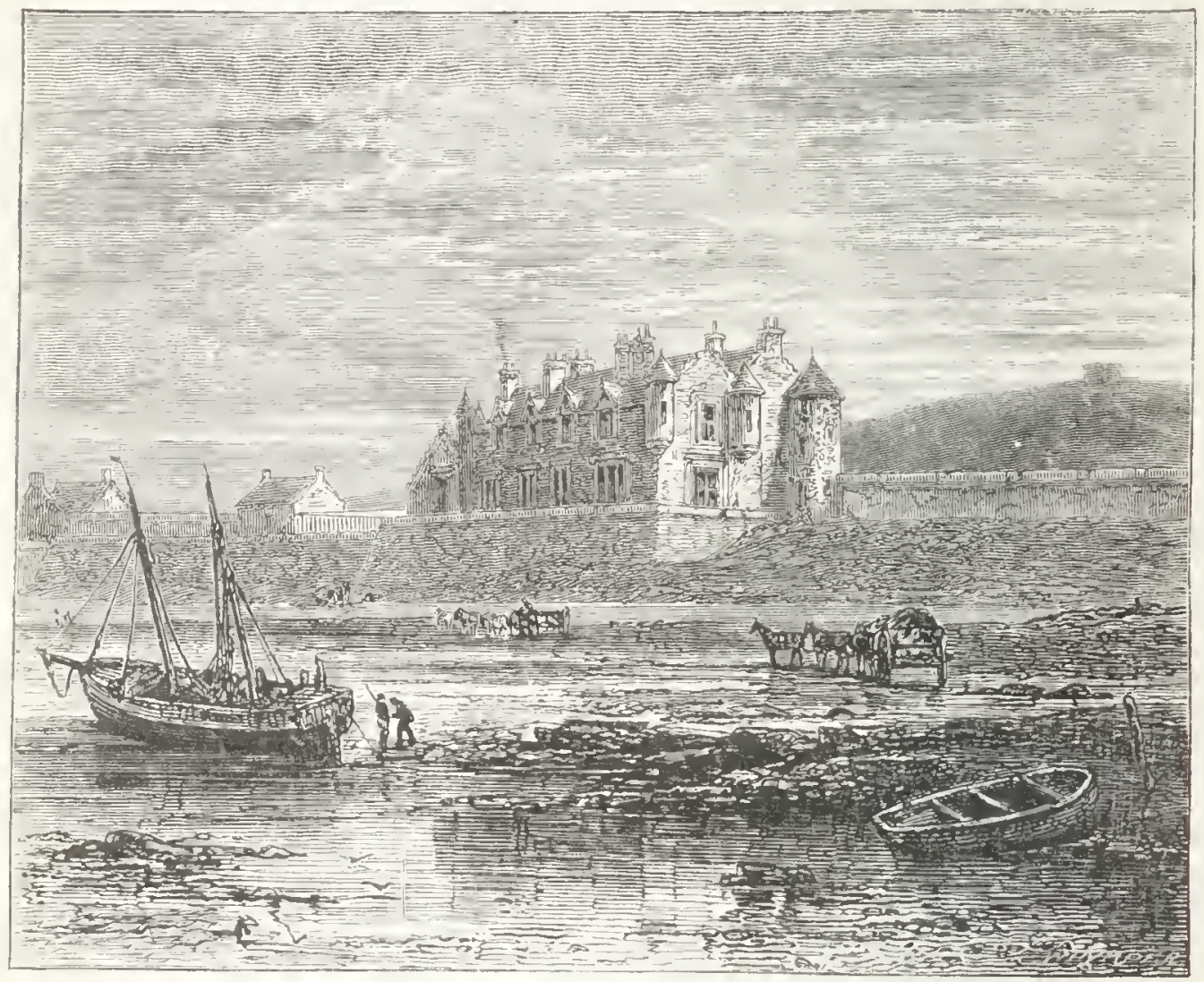

OLD THURSO CASTLE: FROM THE SHORE.

could, up the Thurso river; and I am not far from the truth when I say that he talked all the way. 'I begin slowly', he said, referring to his walking, 'but we'll improve before long;, and so it proved; for before he had reached Oldfield he had got into a four-miles-anhour pace, and by the time we reached Isauld it was a regular trot and race down the banks and across the river to one of his favourite haunts. I cannot now 
remember what were the special prizes of the excursion, though I well remember that we came home richly loaded with things, to me rich and rare, which, with his usual kindness, he named and labelled for me next day. After a lapse of more than sixteen years, I lighted accidentally one day on a pile of plants, collected principally in Caithness, and forming my first herbarium. It had passed through the hands of Mr. Dick, and bears his sign-manual on every sheet. Any one would say it is the handwriting of an educated man - a bold, full, fluent hand-without any trace of the crampedness and angularity of those who earn their bread by manual toil. Besides, the technical names of the plants are always spelt correctly."

But it was very seldom that he made his botanical excursions with others. He almost invariably went alone. When he had arranged his work, and had a journey in view, he had everything in order by the hour that he intended to set out; and then nothing would detain him. When about to start on a long journey, he wore thick-soled boots, with hob-nails in them. He soaked his stockings with water; and when he came to a burn he soaked them again. He took with him some ship biscuit, which was easily carried. This constituted his principal refreshment during his long journeys. The burn or the mountain tarn supplied beverage enough for one of the most temperate and enduring of men. "I never drink much when travelling," he used to say. "It takes the wind out of me, and seriously interferes with my comfort and endurance." 
How he delighted in spring! He welcomed its approach with joy. The winters were usually cold and stormy. The cold winds blew violently over Caithness, and prevented any green thing appearing on the surface, But Dick was up before the sun was up. He was out before the flowers were out. He watched them thrusting their way upwards into the air, watched them while they blossomed into flowers, and watched them while they shrank into decay.

Spring is late in the north. Even at the beginning of May the earth is still brown. Only in some sheltered spots by the river-side are any green things to be seen. There are very few hedges near Thurso. "On the 4th of May," says Dick, "the buds are only swelling. There is no 'May blossom' in Caithness. Even at the end of May the ferw hedges are not in full leaf." The first flowers that appear are the yellow Coltsfoot, the yellow Primrose, the yellow Buttercup, the Marsh Marigold, the little yellow Celandine, and a few blue flowers of the Dog Violet. These are all the beauties of the northern flora in May. The cold winds are still sweeping over the county.

Dick went out one morning at the end of May, towards the Reay hills, to see how the flower's were growing. The morning was cold and cheerless. The flag fences along the road were hung with rain pearls. When he reached the Reay links, he found the ground covered with cowslips. From thence he went up the hills to the waterfall to gather ferms. They were only beginning to expand. The summer moss, Polytrichum. 
was there in thousands. By and by everything would be in bloom.

Even on the 24th of June-midsummer daythe ferns were not fully out. "The first fern I saw," says Dick, "was Lastrea dilatata, but it was so ugly that it was not worth looking at a second time. The next I saw was Asplenium triehomanes, or Common Maiden Hair ; but the specimens were too small for my purpose. The next was the Black-stalked Spleenwort. I passed through a forest of brackens, and saw the Northern Hard Fern, and the Black Bog-rush - a plant rare in Scotland, even on the west coast. I passed on and went up-hill, where I saw the Beech Fern and many other plants, of which European Sanicle was the most abundant. It was once thought to cure every disease, and was called 'Self-heal.' I saw the Common Polypody, and the Oak Polypody. Up the hill the Foxglove was the most conspicuous. I also found Woodruff, Spottedleaved Hawkweed, and Persian Willow; white roses and red roses; and other plants too numerous to mention. I wound along by a sheep-road to the hill-top, and lay down, looking across the dead level of the county. I counted thirteen lochs!"

At the beginning of July, he adds,-_"We are just getting into first-rate order here as to wild plants. We shall by and by have a grand display of yellow flowers -all yellow; tens of thousands, and ten times ten,all destined to pass away after fulfilling the great end for which they came into flower-leaving seed for times to come times without end." 
On the 24th of July he says, "Now it gets warmer. The corn becomes half full of marigold. The heather begins to bloom. I made for the seaside," he adds, "and found a butterfly sleeping on the heather! Poor thing!" As the summer heat increases, the Caithness grasses, plants, and flowers, make their appearance in succession. "People in the south," says Dick, "think that as Caithness is so far north, its flora must differ greatly from that in their own neighbourhood. No doubt the general aspect of a district in the south differs very strikingly in its prominent features. And yet, after all, we have very few plants that may not also be found in the south.

"The Caithness flora is not alpine-not even subalpine. I know of only three Baltic plants in Caithness; and of these only one is a rarity. Indeed it is peculiar to Caithness; for Caithness is the only British district in which it grows. We have the Baltic rush by the river-side. But then Juncus balticus grows at Barry Sands, near Dundee. Last summer, I was much pleased to meet the Baltic rush growing in a small marsh about six miles inland. I was highly delighted. I had never seen it so far from the sea."

Robert Dick proceeded with the study of botany in the most resolute way. He would take nothing for granted. Where others had observed, he also would observe, and verify for himself. Hence, with the utmost toil and labour, he wandered over Caithness, to see the plants growing in their native habitats. He must find them where they grew, and study them, from 
time to time, on the spot. He determined to master the entire subject. He mapped out the country into districts, and resolved carefully to examine each of them in turn. It was a long and arduous work, but he suc-' cessfully carried out his purpose. At length the plants of Caithness, from one end of the county to the other -from the Morven hills in the south to Dunnet Head in the north-from Noss Head in the east to Halladale Head in the west-became as familiar to him as the faces of familiar friends.

The banks of the river Thurso were among his favourite haunts. He searched the valley in its remotest nooks,from its source in Bencheilt to its entrance into the sea at Thurso. The flats along its serpentine course abound in plants and grasses, which he scanned with the true naturalist's eye. During the long summer nights, when "day never darkens into mirk," he would make journeys of forty or fifty miles, for the purpose of gathering some favourite plant in its far-off native habitat. He would return home in glory, bringing with him a stem of grass, a flower, or a bulb.

During midsummer time in the north, it is light nearly all the night through. The sun slightly descends below the horizon, but the light still remains. Farther north, the sun is seen at midnight. When it rises in Caithness, the morning is a prolonged dawn. An eloquent writer says, "The earth is most beautiful at dawn; but so very few people see it, and the few that do are almost all of them labourers, whose eyes have no sight for that wonderful peace, and coolness, and unspeakable 
sense of rest and hope which lie like a blessing on the land. I think if people oftener saw the break of day, they would vow oftener to keep that dawning day holy, and would not so often let its fair hours drift away with nothing done that were not best left undone."

Dick had many a long and lonely walk at sunset, at dawn, and even at midnight. And yet he was not lonely. His love of nature made a paradise of that bare north country. His solitude was not loneliness. Solitude, to him, was sweet society. He felt the companionship of nature about him-on the mcors, in the mountains, and along the sea-shore. On calm evenings, when the sea was at rest, he walked along the sands. The sea, though quiet, seemed to breathe. It was like a living thinglike a creature at rest.

Dick was an insatiable wanderer. When he had done his daily work, and the weather was fine, he set out on his botanical excursions. The county was all before him. He would go to the Reay hills in search of ferns; or up the Thurso river in search of plants and grasses; or to the extreme point of Dunnet Head. His eyes were always open to receive new impressions. He wondered at the infinite varieties of nature, even in that cold bare country. The lines written by Longfellow upon another great lover of nature, are quite as applicable to Dick:

"And he wandered awn and away

With Nature, the dear old nurse, Who sang to him night and day The rhymes of the universe. 
"And whenever the way seemed long,

Or his heart began to fail, She would sing a more wonderful song,

Or tell a more marvellous tale."

He was more joyful on the moors than amid the noise of streets. There he was alone with himself. Not a sound was to be heard as he trudged along, save the beating of his own heart-not a voice save that of heaven. The clouds threw their purple shadows over the moor. The grouse flew up with a whirr, whirr! The blue mountain hare flew past him, though there was no danger to be apprehended from him.

The deluge sometimes caught him. One afternoon, in August, he walked thirty-two miles amidst soaking rain. He had gone up to the top of a mountain, and found only a plant of white heather. He walked and ran all the way back, through moors, mosses, and heather, jumping the flagstone fences; and at last reached home after nine and a half hours' walking and running. Yet he was up next morning at six, and went through his day's work as usual.

The following is a pleasanter day's adventure. It was written to his sister at the end of August:- " Since I wrote you last, I have managed to walk thirty-six miles. Long, long ago, I chanced to find a Fern eighteen miles up the country. It was not new, consequently not a discovery; but it was as good as such to me. It had never crossed me in all my wanderings, or rather I had never found it until then. No one told me where it grew, for the best of reasons - that no one knew. 
Since I first found it, I have every year gone a-walking to it, just to visit it, again and again. This year, I have been there and back. The fern is very small : I enclose a specimen. It is the Rue-leaved, or Wall Spleenwort. The rocky spot in which it grows contains many other ferns, soine of them not at all common.

"Besides the wild rocky scenery of the place, there is the only approach to a Highland glen which we have in Caithness. You set out from Thurso, and for the first three or four miles there is nothing but corn and bere on each side of the road; and in dry leas, showers of yellow Crowfoots and Ragworts; with here and there the blue heads of Scabious, or yellow Dandelions, or yellow Hawkbits. All is yellow, yellow, dashed here and there with masses of purple heath, redder by far than you can possibly imagine.

"On you go, diverting the time as you best can,-—for all is wonderful. Then, at the distance of ten miles from Thurso, you are on a hill-top, and you stand and look around you. It is sweet to stand on a hill-top, and gaze far up the country. Southwards you see farther than you will ever wander. Of course you cannot tell in words all that you see. You gaze eastward, northward, and westward; and then, after satiating yourself with the prospect, you move down the farther side of the hill, and get onward. Twelve miles, thirteen miles, and many wonders are to be seen. And in due time you get among the heather-heather everywhere-and water black to drink. After going a mile through a moor, you find yourself all at once on the brink of a 
precipice. You look down, and the waters are tumbling and surging below; you are satisfied, and could sing with joy too. After a time, I went my way homewards."

Dick often relieved his solitary moments by writing to his sister, then living at Haddington. She had complained to him of her lowness of spirits, when he thus wrote:- "Cheer up, cheer up, my bonnie sister, and I will tell you a story. One fine summer evening, not long ago, your brother set ont for the far-away hills. He had been there before. The sun's heat was strong when he set out (it was then August), but on he went, past bothies, and houses, and milestones, until he was 'o'er the muir amang the heather.' Then past burns and lochs, up a hill and over a hill, through a bog and through a mire, until the sun set, and still he was toiling on, with a long, long moor before him.

"Have you ever been all alone on a dreary moor, when the shadows of the coming darkness are settling down, and the cold clammy fog goes creeping up the hill before you? It is hard work and very uncanny walking to pick your steps, as there is no proper light to guide you. For you must remember that moors are not bowling-greens or finely-smoothed lawns. They may be flowery paths, it is true, but very rough ones, full of man-traps, jags, and holes, into which, if you once get, you may with difficulty wade your way out again.

"But on I went,-hop, step, and, jump,--now up, now down, huffing and puffing, with my heart rapping against my breast like the clapper of a mill. Then 
everything around looked so queer and so quiet, with the mist growing so thick that it was difficult to distinguish one hill from another. Had I not been intimately acquainted with every knowe and hillock of the country through which I was travelling, I never could have got through it. But, cheer up! never lose heart! There's the little loch at last, and there's the hill! Ay, but your work's not done yet. You must climb the hill, for what you seek is only upon its very top.

"It's rough work running through a moor, but it takes your wind clean out of you to climb the hill that lies beyond it. Were you ever up a hill-top at night, your lee lane, with the mist swooping about you and drooking your whiskers and eyebrows? I daresay no. But up this hill I had to clamber on my hands and knees to find the plants that I had come in search of. Yes! I found them, though I was not quite sure until the sun had risen to enlighten me. Then I found that I had made out my point.

"The light enabled me to make my way downhill. Feeling thirsty, as well I might, I clambered over rocks, and braes, and heather, to a very pretty loch at the hillfoot. Picking my steps to a place full of large stones, I came to a pair of them where I stooped down into the clear water and drank my fill. It is a grand thing to dip your nose down into the water like a bird, with the shingle and gravel lying below you, and then take your early morning drink.

"But 1 have no time to say out my say. Only this, sister, only this : never lose heart in the thickest mists 
you should ever get into; but take heart, for assuredly the sun will rise again, and roll them up and away, to be seen no more."

In a future letter to his sister, written on the 12 th of November, he thus describes his journey to Morven top :-

"On Tuesday last I set out at two o'clock in the morning to go to the top of Morven. Morven is a hill to the south of this, and by measurement on the map 28 miles as the crow flies. But taking into account the windings and turnings of the road-up hill, down hill, and along valleys-it is a good deal more: say 32 miles from Thurso to Morven top.

"For the first 18 miles I had a road: the rest of the way was round lochs, across burns, through mires and marshes, horrid bogs, and hummocky heaths. I tucked up my trousers, and felt quite at ease, though I was ankle deep, and often deeper, for fifteen minutes on end, and sometimes more. When I had a marsh to wade I had it level, but when I had heather I had an awful amount of jumping. . . . At last, however, I found myself on the top of the famous Morven.

"The Caithness people have few hills. They think a mighty deal of Morven and Maiden Pap and Skerry Ben. But these hills are not much to boast of. They are none of them as big as books make them, and I laughed when I thought of what people had said to me about this wonderful Morven. One said that it was so very high that it would take half a day to climb from the foot of the hill to the top. Another account, given in a book, 
stated that Morven could only be ascended from the west side, being totally inaccessible on all other sides. Downright nonsense! Morven is accessible on every side.

"My object in ascending the hill was to gather plants, and of course I went up the steepest face to get among the crags and stones near the top. Morven is poor in plants. I found nothing new. True, the season was too far gone, but there in sheltered spots many of them still lived. On the top Alchemilla alpina was in flower. I observed from the decayed leaves on all sides that the various species were not many. Braalnabin, a much lower hill, and much nearer to Thurso, is better for ferns. Two weeks since I went there and got nine different ferns all in bloom, though none of them were new to me.

"Strange it was to look around me. The day was cold and stormy. The sun was shining above me, but a snowstorm was battling far below. Skerry Ben was grey-white with snow. The sound of the wind among the crags was like the roaring of the sea along the shore.

"I reached Morven top at eleven o'clock A.M. and left it at two P.M. It was now mid-day. The river of Berridale runs at the foot of Morven. The best way of getting over it is to wade through it; but what of that? The Highlandman walks best when his feet are wet, and so does the Lowlandman, if he could only be persuaded to try. In going to Morven I had waded no fewer than six burns, and at least a score of marshes. My feet had not been dry since seven in the morning. 


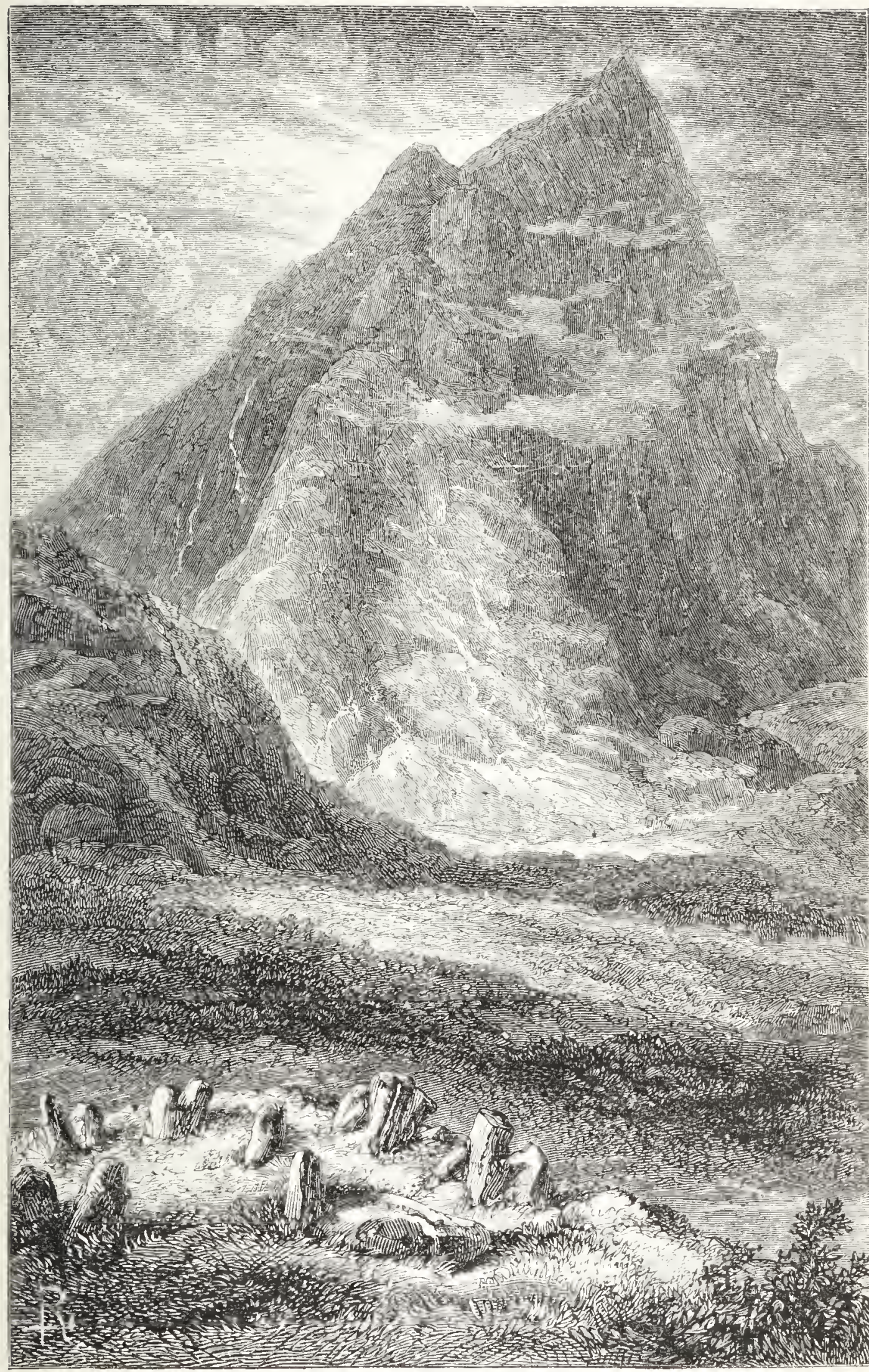

MORVEN MOUNTAIN. 

It was all the same to me which way I took. 'Onward!' was the word. And yet the light of day was gone and the moon was up, long long before I gained a civilised road.

"The night became windy and stormy. Tremendous sheets of hailstones and rain impeded my progress, so much so that I thought, as Burns says, that " the deil had business on his hand,' and that he was determined to finish my course with Morven. But no! In spite of hail, rain, wind, and fire (in fact I had them all), I got home at three o'clock on Wednesday morning, having walked, with little halt, for about twenty-four hours. I went to bed, slept till seven o'clock, then rose, and went to my work as usual. Sixty miles is a good walk to look at a hill. Oh, those plants, those weary plants!"

On one of his midnight excursions Dick was taken for a poacher. It may be mentioned that the river Thurso is one of the best salmon rivers in Scotland. Indeed, in early spring, there is no river that comes up to it. Sir John Sinclair boasted that on one occasion 2500 salmon had been caught at one haul-a draught that has never been exceeded. The price paid by the salmonfishers is so high —at present $£ 20$ per rod monthlythat the river is carefully watched to prevent poaching.

One night a gentleman in charge of the river went out to see that the keepers were doing their duty, and also to detect the poachers if he could. He went to a particular spot where there were evident traces of poaching. The river was then in good poaching order.

Just at the break of day, an hour or more before sun- 
rise, the watcher saw the figure of a man on the horizon, some hundred yards distant. He shrank down, and crept forward, watching the man's movements in the grey dawn of morn. He was seen close by the river's side, prowling up and down the banks. Surely this must be a poacher. The man moved on. When he appeared on some high bank, the watcher hid himself so that he might not be seen between him and the horizon. He crawled forward on all fours, stalking the poacher as he would a deer.

At last, after nearly two hours' stalking and dodging, the man suddenly disappeared in some low crevices in the rocks, just below Dirlot Bridge. The sun was just rising; the watcher saw him crouching down, as if hiding something amongst the ferns. Of course it must be a salmon! With beating heart, he suddenly rushed up to the man, and shouted, "Now I have caught you poaching!"

The man's back was towards him. He was intently gazing on some object before him. He turned round in a composed manner, and said, "No, sir, I am not poaching; I am only gathering some specimens of plants!" He then opened his handkerchief, which contained some herbs, plants, and flowers. The watcher was disappointed and disgusted. He had been crawling for two hours on his hands and knees, coming up with his man, and finding in his possession, not a salmon, but a lot of things which, in his estimation, were worse than useless !

Dick was then sixteen miles from Thurso. He had 
left home at midnight in search of his favourite botanical specimens. Some of them were so minute and delicate that they could only be seen at sun-dawn. It was only at the break of day that they unfolded their delicate tints, spread their leaves, and put forth their lovely blossoms to the rising sun-perhaps revealed to the perfervid botanist by the glistening of a dew-drop.

Thus Dick was rewarded, but not the salmon-watcher who had stalked him. 


\section{CHÁPTER VII.}

\section{DISCOVERS THE "HOLY GRASS."}

"IT is surely," said Dick to a friend, "a strange time we live in, when a poor devil cannot gather weeds without being made a nine days' wonder of to some, and a butt of derision to others."

Many people about Thurso, who saw Dick coming into the town with his feet bedabbled with dirt and his jean trousers wet up to the knees, said that he would have been much better employed in attending to his bakery than in wandering about the country in search of beetles, bumbees, ferns, and wild plants.

But he never missed attending to his business. Science was his pleasure; and the pursuit of it became his habit. One science led to another. From Conchology he went to Entomology, and from these he went to Botany and Geology. Nothing came amiss to him. He found "sermons in stones, and good in everything."

For a long time he kept all that he did to himself. He had no friends to whom he could communicate the knowledge he had acquired. He was only a poor baker. He did not mix with the educated class. He spent his thrifty savings on books. His 
dress cost little. His best clothes were many years old. His long swallow-tailed coat with brass buttons was considered antediluvian. His tall chimney-pot hat was entirely out of date. Sometimes he was jeered at as he passed along.

The boys knew that he had a love of nature. This is the first taste that a country boy develops. Sometimes they were a little frightened at him. They viewed him with awe, if not apprehension, when they encountered him amoung the rocks with his hammer and chisel, or came upon him as he emerged from a ditch, or from behind a turf wall, in his pursuit of insects, or grasses, or mosses. But their fear was always tempered by the knowledge that any curiosity they alighted on, in the shape of a stone, or a butterfly, or a beetle, would always be repaid by the mysterious man when brought to him, by a roll, or a cookie, or a biscuit, or sometimes by a sixpence.

One boy-now a well-known minister-called upon Dick when about twelve years old. He was sent, with another boy, as a deputation from a number of their schoolfellows, to ascertain something about the bones of a cuttle-fish which they had found upon the shore. The boys went into his shop with considerable fear; but they found the baker in excellent humour. He brought down from his library several books, which he spread out anong the loaves of bread on his counter, and pointed out to them specimens of other cuttle-fish bones that had been found. "We were much astonished," says the minister, "to be told that if we came back when 
he was less busy, he would tell us more about it; but neither of us ever mustered courage for a second visit."

Another says-"Boys out bird-nesting on the braes, or fishing by the river-side or amongst the rocks, have often got from him a lesson in Natural History which they would hardly forget in a lifetime."

Dick began to be considered a general referee. When anything unusual was found-a plant, a stone, a butterfly, or a fish - he was at once appealed to. One day a boy came in with a message from a fisherman. A sunfish had been caught in Thurso Bay, and brought ashore. Dick was sent for to come and see it. He was busy with his bread at the time, and could not leave the bakehouse. The fisherman sent another message, saying that if Dick did not come down immediately, he would cut up the fish. "Then tell him to cut away," said Dick; "I don't like these peremptory orders."

A person who made considerable pretensions to botanical knowledge met him one day, and asked if he knew whether the county produced any Statice armeria. "Oh!" said Dick, "if you will just call it Lea Gillyflower, or, if you please, Thrift, you will find it at any roadside."

Another gentleman found a pretty flower growing profusely in a small strath a few miles out of Thurso. He took it to Dick. "Do you know that?" he asked. "Yes," he said; "you got it at the side of the burn at Olrig:" "How do you know that?" "Because it grows in two or three more places in Caithness; but these are too far off for you to have been there to-day." 
Another called upon him with a strunge flower. "I have got a new thing for you to-day, Mr. Dick!" "Oh no," said Dick, "I know it quite well. You got it near Shebster" -indicating a small hillock on a moor in the western part of the parish of Thurso. "Yes," said the inquirer; "but how do you know that?" "Simply because it grows nowhere else in Caithness."

Thus, in course of time, he had pretty nearly mastered the botany of Caithness. Among his other discoveries of plants in Caithness, which had before been altogether unknown, was his discovery of the Hicrochloë borealis, or Northern Holy Grass, on the banks of the river Thurso. It is called Holy Grass, because the people in Sweden and Norway were in the habit of strewing their churches with it. It emits a scent when lying in quantities, and when trampled on by the feet of the worshippers. It is detected, when growing, by its beautiful spiral stem and its rich golden seed.

The plant had been first admitted into the British Flora on the authority of Don. But no one else had found it. After the death of Don the plant was placed in the doubtful list of the London Catalogue, and it was finally dropped out altogether. Dick was surprised at the discovery, but he took no means to make it known. He kept the plant for about twenty long years beside him. He was too solitary and too bashful to rush into print with his botanical findings. It was only when a young botanist, who had heard of Mr. Dick's scientific knowledge, called upon him, saw the plant and ascertained its habitat, that the information about the new 
plant was communicated to the Professor of Botany at Edinburgh.

The professor at first doubted the existence of the plant in Britain. He could scarcely believe that it existed in Caithness, the northernmost county of Scotland. He observed, however, that if Dick had really found the plant, he had rescued the celebrated botanist Don from an undeserved calumny. For Don had asserted that the plant was found in Britain, whereas all the botanists of note averred that the Holy Grass was not indigenous, but had been imported from other countries.

Dick was specially requested to send a communication respecting the plant, and where it was to be found. He accordingly did so in July 1854. He also sent a specimen of the Holy Grass to Professor Balfour of Edinburgh. We must here anticipate; and insert the paper which Dick prepared for the Botanical Society, twenty year's after the plant had been found. The paper runs as follows:-

"About ten minutes' walk from the town of Thurso there is, by the river-side, a farm-house known by the name of the Bleachfield, opposite to which, on the eastern bank of the river, there is a precipitous section of boulder clay; opposite to the clay cliff, and fringing the edge of the stream. Any botanist can, in the last week of the month of May, or in the first and second weeks of June, gather 50 or 100 specimens of Hierochloë borealis. Passing upwards along the river bank, and at no great distance, there is another clay cliff, where a few hundreds of Hierochloe may likewise be got. It also fringes the 
edge of the river. But the plant must be looked for at the time indicated; for by the third week of June the beauty of Hierochloë has passed away, and by the first of July the herbage has become so rank that the Holy Grass, now ripe, and turned of a silky brown, and is completely hidden from view. Farther up, between Giese and a section of boulder clay a little below Todholes, the plant may likewise be picked in hundreds. Hierochloë has never failed to appear in these localities during the last twenty years."**

The Royal Botanical Society afterwards sent Dick a special vote of thanks for his paper, and also for the specimen of the plant which he had sent for the Botanical Gardens.

To return to his botanical wanderings. His sister, who lived at Haddington, was very delicate, and he often tried to amuse her with the descriptions of his walks in the country.

In the beginning of July he writes to her as follows: - "I have had two walks-one of five miles, the other of ten miles. The five miles' walk was to see a fern called the Moonwort. It grows in abundance in a spot not far away. I shall never forget the strange wonder with which I first saw it. So I again walked off to the locality, where I knew it grew in all its glory. The season has been very dry here, and the fern has not attained its usual height. Nevertheless I found it. During my journey I saw much to admire.

* Annals of Natural History, October 1854. Botanical Society of Edinburgh. 
"My ten miles' walk I had yesterday evening. It was fearfully warm. The sky was full of fire, but it did not rain. There were great black mountains of clouds in the air. It was a dead calm, with not a breath of air. I was told that I must not go out, for it would be a downpour before long. But 'he that will to Cupar maun to Cupar.' My imagination told me of beautiful geraniums (Storksbill), which I longed to see. Off I went! The clouds were in motion, but without wind. It was terribly sultry. After a long perspiring walk I arrived at my journey's end-a small precipice, lined with plants.

"I was now at home-intensely at home. The precipice was not in length a stone's throw. It was only about twenty feet in height. But there I found many most interesting plants. There were a few of the Trembling Poplar trees, about four feet high. There were Roses and Willow Herb in flower (Epilobium angustifolium, $E$. montanum, and $E$. quadrangulum). There was Arabis hirsuta, a plant I never get in Caithness but here: Stone Bramble, Common Sanicle, Carices, and Butterworts in scores. And in the crevices of the crags ferns-Male ferns and Lady ferns-Black Spleenworts, Maiden-hair Spleenworts, and many other plants. Among the rest I found plenty of Rough Brome Grass-a grass I saw alive for the first time-alive by scores. So here was my reward! Well, I am increasing in knowledge, if not in wisdom. I hope to get up at one o'clock tomorrow morning."

A little later in the month he says_-"This being one 
of my rambling days I did not leave Thurso until the postman had gone round with his letters between one and two o'clock. Of course I could not go far to-day. But there is a fern growing about a mile and a half off, which I should like to see once more. I once thought the fern to be very rare, not having met with it in all my rambles, except at the foot of the hill of Morven, in the extreme south of the county. Then I found the same fern about four or five miles from this, eastward of the Fairies' Hill (Lysa); afterwards about a mile and a half out of Thurso; and then about three-quarters of a mile eastward of the town. The search for plants is amusing; and when I come unexpectedly upon plants in a spot which I had before minutely searched, I wonder where my eyes had been all the time."

"On Saturday last," he says in another letter to his sister, "I got up in the morning at three, worked until midday, and then I set off on a journey of nine miles to gather a specimen of a plant. Before I started I took off my shoes and dipped my feet, stockings and all, into a basin of water. I then tied my shoes on and set off. When I had gone six miles I came to a burn 'roarin' fou,' through which I walked ankle-deep. Fifteen minutes later I walked through another burn, and then through another and another burn-four burns in all.

"I pulled the plant and returned homewards. My route lay across Dunnet sands. The tide was ebbing. I kept close by the waves. As they rolled in, in long breakers, they went far up the sands. For about threequarters of an hour I walked ankle-deep in salt water. 
After leaving the shore I had six miles to walk. I reached home at eight in the evening with my plant, having walked eighteen miles in four hours and forty minutes."

On another afternoon in July he goes to the Dorery hills. "I had a ramble," he said, "on Saturday last, after my day's work was over. While on my way I found in a quarry, at a loch, a fossil fish snout or two, and some plants. I got to the hills, about ten miles off, and examined ferns and roses. I had a grand view of the Sutherland hills. I stood in a sheltered nook, and gazed at the sunlight shining far over the distant mountains. I never forget any of these moments. I turned aside this moming just to gaze upon the moon. It was about two o'clock in the morning. Ali was still, solemn, and impressive."

The road to the Dorery hills lies through a bare and slightly undulating country. The fields are separated from the road by fences of Caithness flag. On either side you observe here and there mounds of green earth, underneath which are said to be the so-called Picts' Houses. After the cultivated fields, come the moors -quiet, solitary, and sublime.

After the moors you reach the heathery hills. The highest of the hills is called Ben Dorery. There is a cleft between the two principal hills, and at the farther side of the main hill is a hollow, surrounded by projections of slaty rock, in which Dick would sit down, and look with delight on the prospect before him. In the farreaching plain below there was nothing but heather, 
moor, and moss, in the midst of which twelve lochs might be seen glittering in the sunshine, with the Sutherland hills far in the distance.

The scene is lonely and solitary. Not a house is to be seen. Not a sound is to be heard, excepting the shot of a sportsman cluring the grouse season. Below the hill, is Loch Shurery, quietly sleeping in the sunshine.

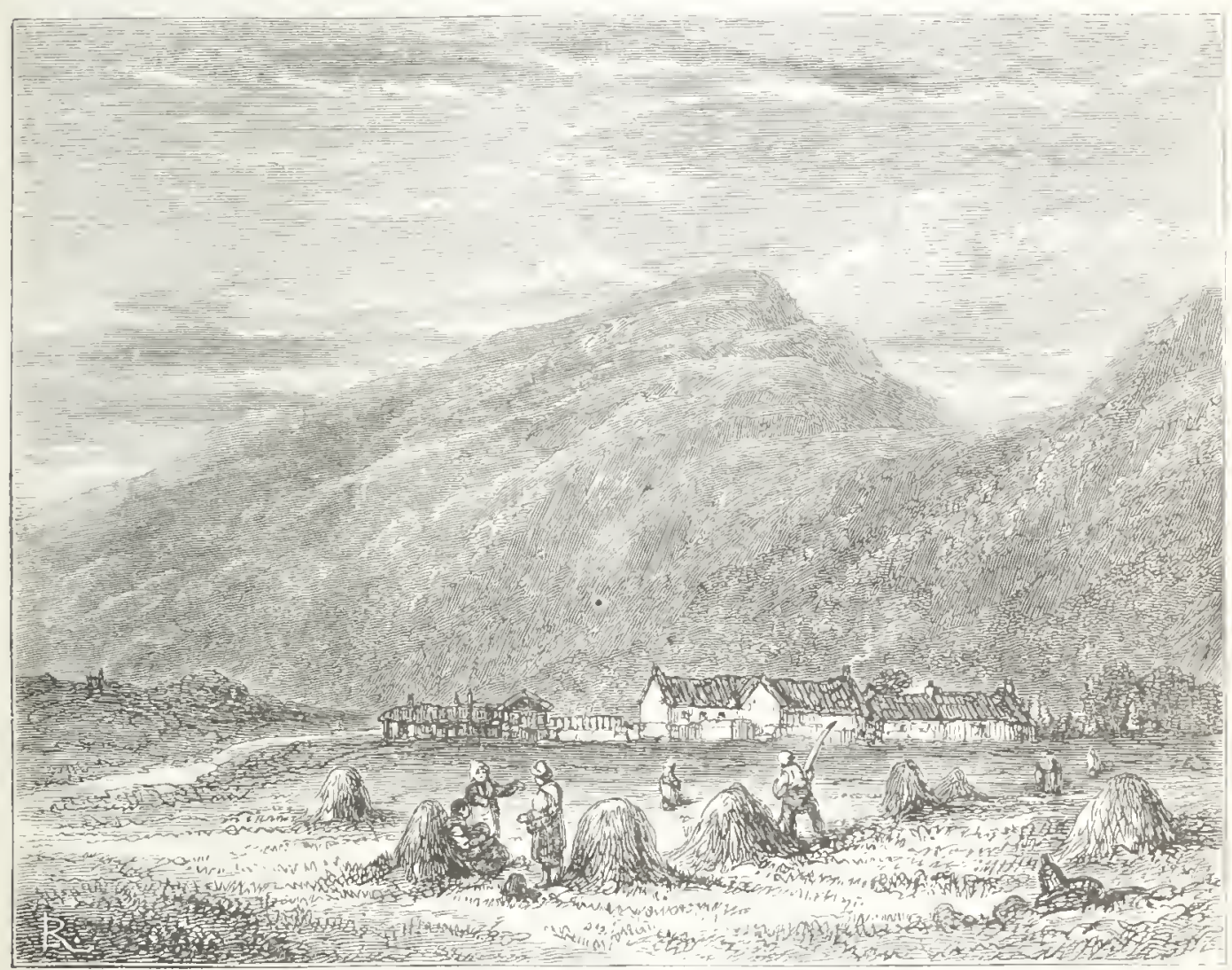

THE DORERY HILLS.

Rising the hill and looking north, you see the flat county of Caithness, with moors and lochs in the toreground, and beyond them the flag-fenced ficlds in the distance. The Dorery hills were attractive to Dick, not only because of the solitary scenery, hut because they were full of ferns of many sorts, together with many of the plants and grasses of which he was constantly in search. 
Dick had another special fernery at Achavaristil, under the Reay hills, about ten miles from Thurso. It was nearly opposite Sir Robert Sinclair's shooting-lodge. It was a sheltered place, where ferns grew in beauty. Dick kept the place an entire secret. For a long time, no one obtained access to it. No one knew of it. He transplanted ferns from all parts of the county, that they might grow and spread there long after he was dead. But alas, some mischievous person found out the place, and pulled up the "weeds." What a bitter day that was for Robert Dick! 


\section{CHAPTER VIII。}

\section{DUNNET HEAD.}

THe coast scenery, east and west of Thurso, is very grand. On the one side it rises into Holborn Head, and on the other into the long perpendicular rocks of Dunnet Head. Holborn means Hell's child, from Holla the goddess of hell, and biorn child. Many a ship has been dashed against the rocks there. This has probably originated the peculiar name of the headland.

When a ship in the North Atlantic is caught by a storm, and the wind blows violently from the west, she is driven towards the rockbound coast of the Hebrides. If she can weather the Butt of Lewis, she is driven towards the gigantic rocks of Cape Wrath, which extend for about fifty miles towards Holborn Head. If she can manage, by backing, to enter Scrabster Roads, she is safe. If not, she is driven upon the rocks, and utterly destroyed-ship, men, and cargo.

The faces of the rocks are hollowed into gaping caverns, where the waves thunder in, and roll along the gyoes far inland. The leap of the waves is only exceeded by their rebound seaward again. They rush up the face of the rock like a pack of hounds, and spread themselves along the summit in blinding showers of spray. 
As you stand upon the top of the rocks in fine weather, they seem to precipitate themselves into the sea,--in many cases overhanging the water.

Inside of Holborn Head is Scrabster Roads. Many ships ride at anchor there while the wind blows hard from the west. They are well protected by the headland, which juts out towards the north-east. Scrabster Harbour is also comparatively safe.

But when the wind blows from the north or northeast, the ships riding at anchor there are in great danger. The waves come in with great force. They come hissing along with their fleece of froth, and break with violent force upon the shore. They rebound again, dragging the pebbles under them with a rattle, and - to quote the words of Hardy - are like "a beast gnawing bones."

After one of these storms, Dick went down to the sea-shore to ascertain whether any of the secrets of Nature had been laid bare. "We have had a terrible storm here," he says; "such a force of wind that I have never felt the like, so terribly strong and continuous. It has caused great disaster to the shipping. The storm fairly whipped six ressels out of Scrabster Roads, and dashed them ashore to ruin.

"When the wind abated, I went down to the shore, and found a piece of old land strewed here and there with prostrate hazel stems. I picked out of the clay five nuts. How long it is since they grew I know not, but it must have been ages ago. Perhaps geologists would say that they grew when Britain stood thirty feet higher than it does now. But that is all conjecture. Certainly 
the land along our shores had once a very different appearance."

On another occasion he says- "The wind to-day blows fearfully hard. A large ship, with seventeen men on board, is ashore at Ham, thirteen miles off. About mid-day we expected a ship ashore here. Unless the wind abates, I should not be surprised if others came ashore to-morrow. The wind is howling like mad, and roaring like thunder over the town."

Dunnet Head, north-east of Thurso, was one of Dick's favourite haunts. It was a long walk to the lighthouse, which fronts the Pentland Firth. But he often wandered to it, and descended the headland to the sea by paths known only to himself. The perpendicular rocks which surround the head, average about two hundred feet high; but at the northern end, which forms the northernmost point of Scotland, the rock rises three hundred feet above sea level; and from the summit of the contiguous eminence, the height above the sea is more than four hundred feet.

Dunnet Head forms a peninsula, extending from the village of Dunnet on the south to the village of Brough on the north. From these points it extends northward. The peninsula contains about three thousand acres of uncultivated moor, with $n o$ fewer than ten small lochs or tarns on its summit. In winter time the lochs are crowded with swans, geese, ducks, and northern seafowl. Most of the birds summer in Greenland, and winter on Dunnet Head.

This immense rampart of rocky headland runs along 
the northern shore of Dumnet Bay, by Dwarwick Head, in an easterly direction. Then turning sharp round to the north by Rough Head, the rocks wend northwards, then slightly eastwards, until you find yourself under Easter Head, where the lighthouse is erected. This is the highest point of the cliffs. They then extend to the

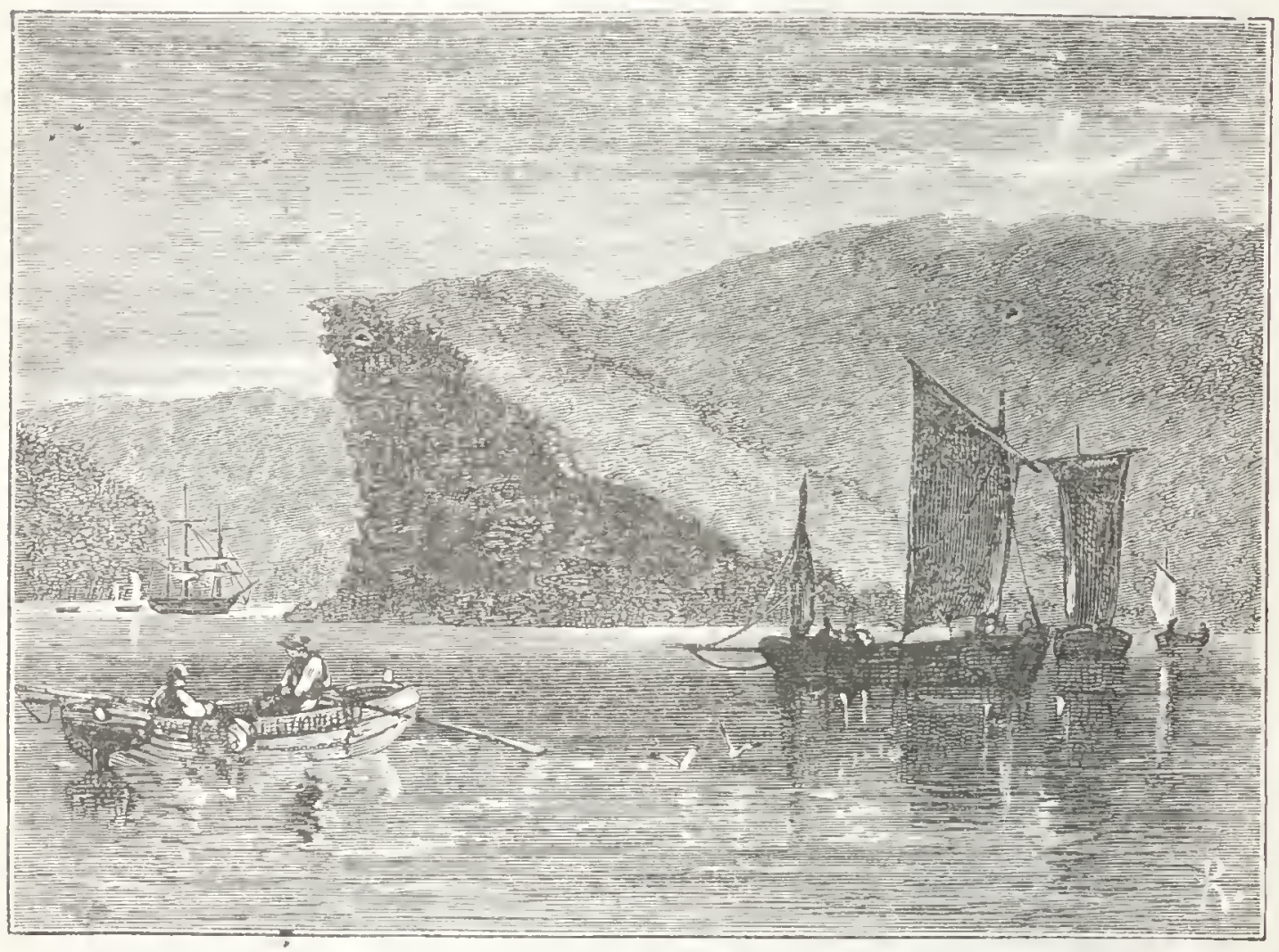

DWARWICK HEAD.

south-east, and afterwards towards the south, ending at the village of Brough.

In fine or even rongh weather, when the wind is east. erly, a yachting trip under the cliffs is full of interest. In Dumnet Bay the sea is quiet, being protected from the east by the high grounds of the peninsula. Dwarwick Head forms a singular headland, the strata dipping slightly towards the sea. Betrreen this and Rough 
Head is a wick or bay, in which ships find safe shelter -an old retreat of the Vikingers.

Rough Head is a bold headland. Numerous boulders are strewn at the bottom of the cliff. There are points near Dwarwick Head and Rough Head, where an approach to the sands is possible, though, in some places, it is rather precipitous. There are numerous gyoes along the headland, worn out into inland caves by the powerful washings of the sea. There is one near Dwarwick which penetrates far inland. When the sea is rough, and drives in from the west, the sea dashes up far inland, and blows through the opening like a whale, throwing abroad sheets of spray.

The precipices gradually rise. In certain places the rocks seem to have slipped away towards the bottom, and left steep slopes overgrown by ferns. There are numerous wild birds among the cliffs. Cormorants are seen winging their solitary way towards the north. Deep caves appear in the face of the rock; with here and there a recent slip from the summit to the sea, where the stones lie in a rough slope. The red sandstone of the rocks looks so clear, so solid, and so near at hand, that it might be thought they were only a gunshot distant, though they are a mile and a quarter away.

And now we are under the lighthouse, where the strata are nearly level. The precipice here is some three hundred feet high. The lighthouse is on the crest of the rocks, only about thirty feet from the precipice. It is the highest lighthouse in Scotland. The height of the lantern above the highest spring tides is 346 feet, 
and the light is seen twenty-three miles off; on either side of Dunnet Head.

Even here there seem to have been recent slips, for there are long slopes of rock at the bottom overgrown with ferns and greenery. The sea is constantly washing and grinding away the red sandstone and slates, so that, in course of time, the lighthouse will have to be removed farther inland.

Notwithstanding the height of the cliffs, the sea, when driving strongly from the west, rushes right up the face of the rocks, and dashes over the lighthouse, sometimes brealing the glass with the stones which it carries with it. Such is the prodigious force of the wind and the sea united, that the very rock itself seems to tremble, while the lighthouse shakes from top to bottom.

We are now in the Pentland Firth, and the waves are rolling strong from the eastward. The wind and the waters dash about the little ship, and she tacks and bears round under the shelter of the headland. But not before her decks have been well drenched by the billows. She has now to make headway against the tide, which is rushing into the Pentland Firth at the rate of some ten miles an hour. At last, retracing her pathway under the rocks, Rough Head is passed; a calm comes on; the ship makes a tack across the bay; and at length Dwarwick Head is passed, and the buoyant little yacht makes her way into Castletown harbour, from whence she set out.

We have thought it necessary to give this account of Dunnet Head, because it was so often the scene of Robert Dick's explorations. Sometimes also, Hugh 


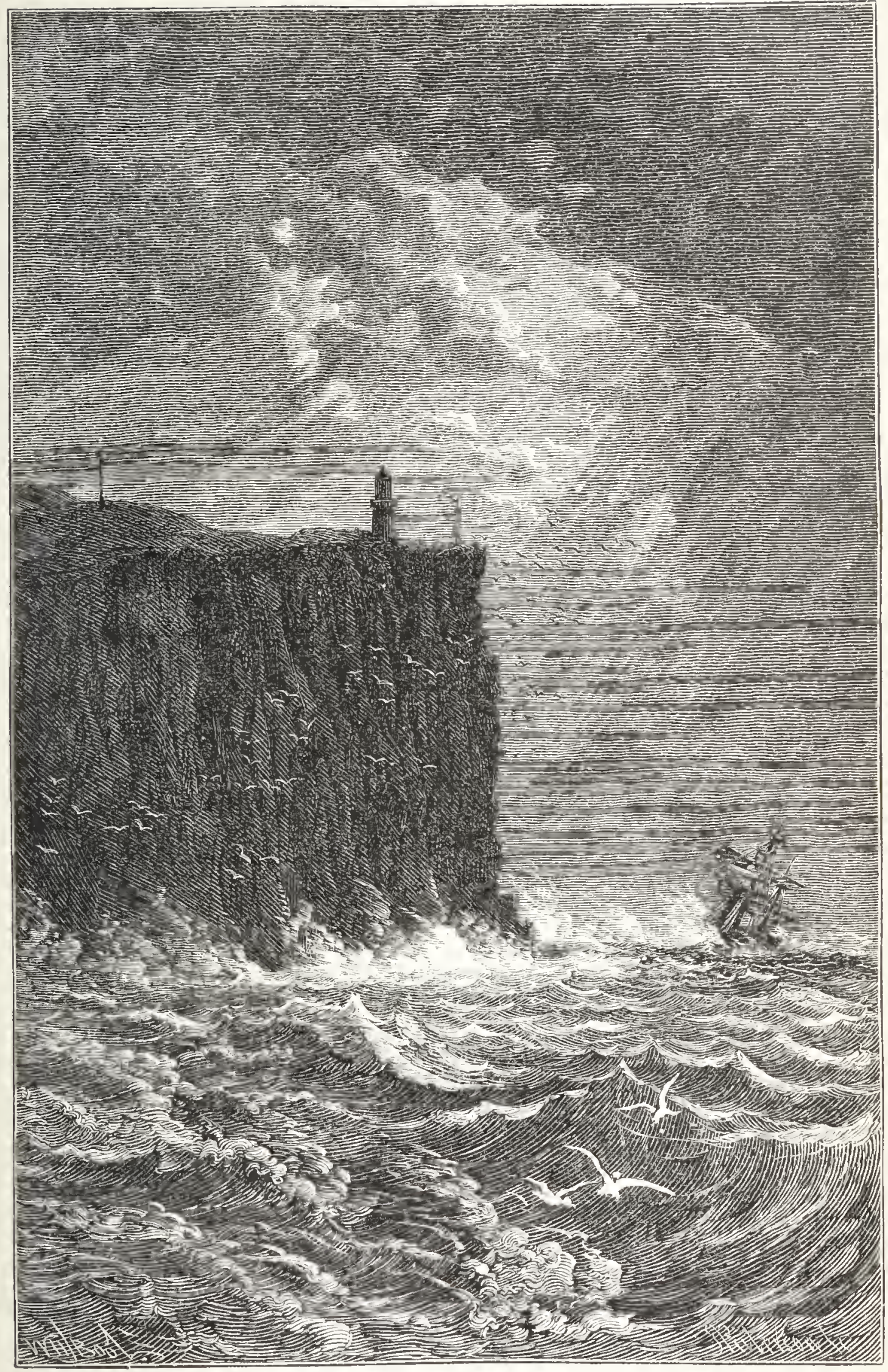

DUNNET HEAD: FROM THE EAST. 

Miller accompanied him in his researches after the Old Red Sandstone, which is found on both sides of the headland. This will afterwards be found in the course of the narrative.

In the course of one of his letters to his sister, Dick thus describes one of his journeys to Dunnet Head. It was made in April, while the weather was still very wild :-

"Determined not to be beat, I waited over snow, hail, frost, and rain, until I could set out. Then I had my ramble. It was a fine morning, but after I had set out it began to rain. It blew and rained for five miles. I saw little beyond a bare country. The fields were red, and the grass by the road-side was withered and brown. All was of a sad, desolate appearance. I was walking in an easterly direction, and the wind was blowing south-west. To fend me from the rain, I turned my face northerly, and saw only a tossing sea, and the Orkney hills overspread with snow. I passed through the milelong village of Castletown, and there I saw trees, yes, most respectable trees!

"On the top of a stone wall to the right I saw some tufts of moss. I went to the moss and looked. It was all in fruit. I think it was Hypnum populeum. I had seen it before. I crossed burn after burn, and then the

* There are not only trees but woods about Mr. 'Irail's seat at Castlehill. There is a hollow valley there, along the river Duran, whieh has been beautifully planted. The place is well protected from the north and east winds, and the trees grow to as fine dimensions as they do in the soutl of England. But this is the only wood in the north of Cairhness. 
long drear'y sands of Dunnet lay before me-blank and bare, or tossed into fantastic hillocks. The sand was blowing before the wind. The waves were thundering along the shore.

"I saw a man breaking sandstone boulders. He little thought of what he was doing, or of the time when ice went grinding along the surface of the stone he was hammering. No: he was building a cottage, and the stone was only a stone to him, and nothing more.

"Passing on, I left all human habitations behind, and had only heather, heather, before me. The heather was brown and burnt-like, so severe had been the weather during the past winter. As I passed on, I found a cocoon of the Emperor Moth sticking on a piece of heather. I was next brought to a stop by some crimsontipped lichens-moss cups. They were taller than any specimens I had seen before, but they were under shelter.

"After crossing another burn, and striding through heather only ankle deep, I found myself on the edge of the precipitous cliffs of Dunnet Head. Before I descended down their front I looked around. Orkney seemed quite near, with the snow-wreaths on its hills. The waves of the Pentland Firth were rolling away westerly.

"Down I went! down! It was at that place only about 100 feet deep. When I reached the foot of the cliff, I gazed upward in wonder and admiration, full of intense curiosity to see the various layers of sand-for such it once was. It is not every day that one stands at the foot of such a cliff. 
"I moved westwards. I passed along delighted. The scene was grand and unusually striking. I came at length to a narrow fissure, up which I forced my way in quest of Ferns. Yes, Ferns! Ferns grow green on Dunnet Cliffs all the year round. In fact, Dunnet Head is a forest of ferms. It was the Sea Spleenwort that I wanted, and sure enough I found it growing green in all its glory. I gathered a few, and left the rest.

"Retracing my steps, I ascended the cliff. It then began to rain, and it rained nearly all the way home."

Dick often descended the cliff, sometimes to gather ferns, and at other times to inspect the geological conditions of the rocks. One day he went down the face of the headland a little to the west of the lighthouse. He went searching about among the rocks and clefts, finding many new things to wonder at. But he completely forgot the lapse of time. Looking round, he found that the tide had risen and completely overflowed the path among the rocks by which he had come. On one side was the precipice, on the other was the sea, coming in higher and higher at every wave. He had no alternative but to go onward, for the sands were still dry in front of him. At length he discovered a portion of the headland which he thought might be attempted, and he succeeded, with much difficulty and danger, in reaching the summit of the cliff.

In fine weather, when the billows are asleep and the waters merely lave the base of the cliffs, pleasure parties sometimes set sail from Thurso, and, when the tide is low, they land on the sands under Dunnet Head. On one 
occasion, Dr. Smith and a party who had just landed from their boat, found to their amazement that Dick was there before them. He seemed to have got there by miracle. But no; he had merely come down the rocks by a path known only to himself, for assuredly nobody else would have risked his life in so perilous a descent.

Dr. Smith asked him to return with his party in the boat. No! he would ascend the rocks by the path down which he had come. Besides, he never accepted any accommodation of this sort while on his journeys. His skin was in a state of perspiration, which he desired to maintain. If he took a seat in a boat or in a road conveyance, with his wet feet, he was sure to get chilled, and the result was a severe cold. Hence he strode back to Thurso by the heather, the sands, and the road, as he had come.

On one occasion Dick describes the geology of Dunnet Head. It is during the month of June that he undertakes his journey. He has already reached Dumnet sands, which are about seven miles by road from Thurso. The description is best given in Dick's own words :-

"Dunnet sands are a long and a weary trail in a warm day in June, when the dark thunder-clouds creep overhead, when not a breath of air stirs, and all is still and motionless, save the dull, shuggish fall, at solemn pauses, of the incoming and retreating waves on the burning sands, or the humming of the overjoyed flies feeding on the dead fish cast up by the tide; when the 
cattle from the benty links have come down towards the sea, where they stand knee-deep in it, stooping and eyeing it wistfully, but yet unable to drink; when the parched" sands stretch away in the distance, the heated air flickering upwards like the breath of a furnace!

"I look up, and implore the 'all-conquering sun to intermit his wrath.' He only continues to shine out stronger and fiercer; till at last, faint and exhausted, I throw myself down, and drink out of the burn which flows across the sands, careless of the consequences. Your very wise people may say what they please about the consequences of imbibing cold water when overheated, but I have never found any harm, but much good to be the result, and in no case more than in taking this drink out of the burn as I crossed the sands towards Dunnet.

"Refreshed and invigorated, I rose and pursued my way. Not long after, I had the pleasure of striking my first hearty blow on the yellow stones which crop out through the unconsolidated beach. I examine and search for organic remains. But no. Again and again my efforts are renewed, and still the answer is, No.

"Passing on along the foot of the cliffs--now yellowish, then reddish-now thin and slaty-like, then in thick solid beds-I go rambling along.

" 'Owre mony a weary ledge he limpit, An' aye the tither stane he thumpit ;'

but thumped in vain. Oh for one scale! But no; no organisms; not one, though you upturned the whole stupendous accumulation of quartzy sand, which rears 
its lofty and weathered front to the wasting waves and sea-breezes.

"We have chosen the right time, when the tide is at the lowest. Consequently we are enabled to move along at the foot of the cliffs, which otherwise would be impassable. We actively and untiringly explore, but with no success; and are at last so wearied that we clamber up to the top of the headland by a rugged sort of footpath, and, moving along the edge of the precipice, we make through the grass and heather for the crags immediately facing the Western Ocean. How strange to find, as we move along, a white butterfly or two flitting about, a solitary mason wasp, and a sparrowhawk looking out for prey, the sun all the while beating down upon us.

"It is possible to get down the western face of the rugged cliffs of Dunnet Head. We got down, and what do we find? The sight is worth all the toil of walking to see it. Immense masses of sandstone, fallen from the cliffs overhead, skirt the mighty wall. The masses lie in rude confusion. Applying the hammer to them, no remains of fish or quadruped are to be found, but pieces of quartz, clay pebbles of a reddish brown, and in some places balls of sulphur-yellow clay, as big as a man's fist. Here and there are large patches of something like rusty sheet-iron, which would almost make one fancy that they were the remains of some Antediluvian Frying-pan that had been swept to sea and buried there.

"There is very little real red sandstone at Dunnet 
Head. By far the greatest bulk is what I take to be a yellow quartzose sand. In one place, and in one place only, is the sand in any way red. In crossing Dumnet sands we had not failed to notice little stones, standing out here and there in the sand, left by the retiring tide, and great was my surprise to find the same appearances here. In some places, where the boulders are a little asunder, the exact beds of the strata are to be seen, walked over, handled, and hammered. I had seen sandstone beds with here and there a pebble, but they never struck my imagination so forcibly as now, when I was down upon my knees and busied in the work of extraction.

"What a vast gathering of sand! I was forced to exclaim. Where did it ali come from? How long did it take to pile up this heap in the silent depths of the sea? How long? How many years? These are pertinent questions,-questions which enter one's very soul. Then man feels instinctively his own littleness, and his utter inadequacy to solve even the simplest of his questionings.

"But however amazed he may feel at this vast pile of sand, it was at one time unquestionably much greater. Looking across to the Orkneys, immediately opposite, the spectator cannot fail to remark that they are of the same material. Then, turning from the Orkneys to Holborn Head, where a strong sea now rolls, one cannot help looking back, and we are led to picture the time when there was no sea between them, but only sandstone beds, stretching continuously from shore to shore! 
"The beds have been burst through by the ocean, and where dry land once was, the grampus now rolls, and the tall ship speeds on her way to the farthest ends of the earth. Amazing change!

"Art, empire, earth itself, to change is doomed;

Earthquakes have raised to heaven the humble vale, And gulphs the mountain's mighty mass entombed; And where the Atlantic rolled wide continents have bloomed.'

"Who told Beattie this? It seems to prove Lyell's theory of the sameness of ancient and existing causes for geological changes in the earth's surface. And the change is still going on; and 'come it will, the day decreed by fate,' when not a vestige of the sandstone of Dunnet Head will be found above the encroaching ocean.

"What induces me to think so is this:-1st, Dunnet Bay does not, in my opinion, owe its existence to a fault, but has been literally hammered out by the force of the Atlantic waves. The sandy links are the broken remains, in part, of the dispersed strata; and were they now to become solidified, they would be found as rich in fossil remains as the present beds are barren. 2d, The ocean tempests are telling surely on the western face of the beds of Dumnet Head; and time alone is wanted to effect their ruin. 3d, The beds on the south, at Brough, are in some places in a mouldering, crumbling state, and the sea will ultimately effect a junction with the upper end of Dumnet Bay. Dunnet Head will for some time be an island; but it will ultimately be 
blotted out of existence altogether. There is a prophecy for you!

"I remember once getting up, towards the end of harvest, while the blue canopy above was still adorned and enriched with innumerable star's. I was gaily crossing Dunnet sands in the first peep of day, when I made directly across the peninsula for the stupendous cliff immediately westward of the little haven of Brough. I found that the tide did not retire far from the coast, but rose and fell close to the cliffs, wetting and allowing to dry the big stones at the base of the precipice.

"The cliff, under' which I rested for a time, was about 150 feet high. It seemed sound and hard. The morning sun rose in beauty. I hammered away, and kept moving down upon the hamlet of Brough. There I found the cliffs in sad decay; in fact, they were a sloping mass of rotten materials. A little out to sea there is a ledge of what was once red sandstone. It is a mouldering hint of what is to come. It is 50 feet in height, and rests upon slate.

"I had made this long journey in the hope of finding some very fine organisms where the slate cropped out from beneath the sand. I found a few fish scales and droppings, but no fossils; and sounded a retreat, very much chagrined at having to return home almost empty-handed.

"There is a loch or two near Dunnet Head. There is one on the top of the hill. It is a quiet secluded spot, a place of great attraction for wild swans, geese, and ducks, during their autumnal migration, when winging 
their way southward. There is another loch lower down, famed for its miraculous cures. It is quite common for mothers to carry their sickly children there on the first Monday morning of a Wraith; and, going round the puddle three times, they dip in the chick at the end of each revolution. The children have sometimes returned home cured. So they say.

"I remember a sort of cure. A poor woman took thither a child who could neither sit, stand, walk, nor talk. She performed the customary observances, and returned amidst much derision. But lo! a marked change took place in the child. He gained strength, walked, and learned to speak. He often came to my back premises, and called out: 'Bakie, bakie, gie's a lopie;' but still he was very ancient-looking in the face. About two or three years after he died of gravel. So that the cure, whatever it might be, was not permanent."

The piece of water referred to by Dick is Dunnet Loch, or the Halie Loch, not far from the village of Dunnet. It was once supposed to possess great healing virtues. People came from all parts of Caithness and the Orkneys, to be cured by the water's. The patient had to walk round the loch, or, if not able to walk, he was carried round it. He washed his hands and feet in the loch, and then threw a piece of money into it. He had to do this early in the morning, and must be out of sight before sunrise. There was in ancient times a Roman Catholic chapel dedicated to St. John at the east end of the loch. Some say that the alleged healing virtnes of the waters were converted into a source of 
pecuniary emolument by the priests. The loch is merely a collection of water dropped from the clouds, and possesses no healing or other qualities, except those of rain water.

Among the superstitions of Caithness, the Swallow is called "Witch hag." They say that if a swallow flies under the arm of a person, it immediately becomes paralysed. Is it because of the same superstition, that in some parts of England the innocent Swift is called "the Devilin"?

(n)

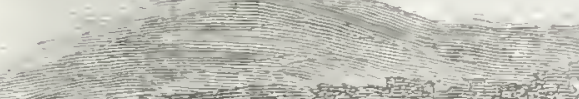
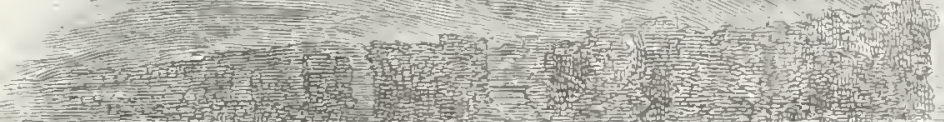

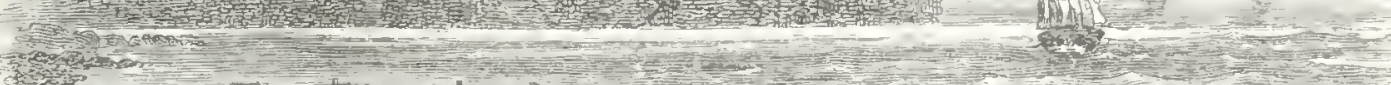

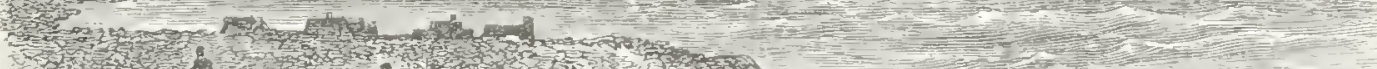

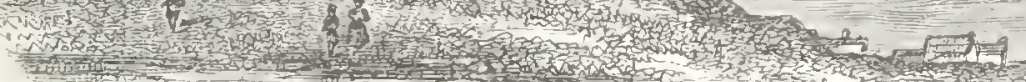

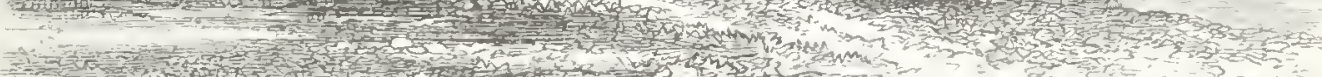

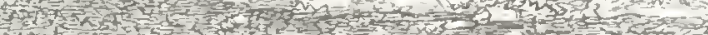

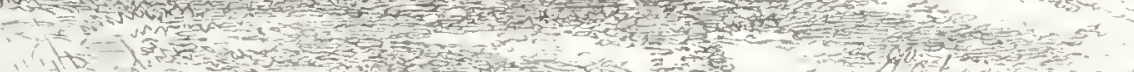
DISTANT VIEW OF DUNNET HEAD: FROM BARROGILL CASTLE. 


\section{CHAPTER IX.}

\section{GEOLOGY-DISCOVERY OF A HOLOPTYCHIUS.}

Robert Dick had now been engaged for many years in studying the wonderful aspects of Nature in the North. Caithness was not too wild or dreary for him. The shells on the sea-shore, the grasses along the river-sides, the mosses growing on the boulders, the ferns abounding in Dunnet cliffs, were all full of interest. And now he proceeded to probe the ground under his feet.

He had long had a taste for geology. While gathering his botanical specimens he had often found fossil fishes in the slaty rocks. He first observed them in 1835, a few years after he had settled at Thurso. At first they excited his wonder; then his surprise,-for distinguished geologists had asserted that no fossil remains were to be found in the Scotch Highlands.* But here they were under his own eyes! Why should he not explore

* 'The Rev. W. D. Conybeare and William Phillips, Esq., in their Outlines of the Geology of England and IVales (1822), said, "A circumstance cannot fail to have struck the observer during the course of his researches, which opens to his view a far more extensive and interesting fich of his inquiry with regard to the relations of these rocks to the general revolutions of nature; for he will have found in many of these beds spoils of the regetable and animal kingrdom inbedrerl, partieularly the remains of marine zoophytes and shells, often 
them? Why should he not study them, and verify the facts for himself?

Among the first books that he bought was Mantell's Wonders of Geology. This revealed to him quite a new world - the world of wonders at his feet. He afterwards bought Dr. Buckland's Bridgewater Treatise. This book also greatly excited his imagination. But there was nothing in it about the fossils of Caithness. He next borrowed a book from Sir George Sinclair, containing a journal of Mr. Bushby's travels through Caithness. He made copious extracts from it, and endeavoured to verify the facts therein stated.

Mr. Bushby's object seems to have been to discover whether Caithness contained any metalliferous ores. He also bored largely for shell marl, with the object of mixing it with the mosses, and thus producing cultivable land. Bushby was not a geologist, and, in his search, for what was valuable, he overlooked the flags, the fossils, the old red sandstone, and many of the most interesting facts in the geology of Caithness.

It was not until the appearance of Hugh Miller's publications that Dick's mind was set in the right direction. In the month of September 1840, there appeared in the Witness newspaper the first of a series of articles under the title of "The Old Red Sandstone."

in such abundance as to constitute nearly the cntirc mass of the particular strata. - . . In some counties, he will perceive, none of these remains occur-for instance, in Cornwall and the Scotch Highlands; in others (as in the south-eastern counties of England) not a well can be sunk, or a pit opened, without presenting them in abundance." 
The articles were collected and published in the form of a book in the following year. Dick purchased a copy, and read it with great interest.

He immediately set to work to investigate the geology of Caithness. He again wandered over it from one end of the county to the other. But his best findings were near Thurso. Along the coast there, he had already found fish bones, fish heads, fish snouts, fish scales, sufficient to freight a large ship. But he had never yet found an entire specimen. At last he succeeded; and then began his correspondence with Hugh Miller.

He did not know Hugh Miller; so that he addressed him through an intermediate friend, Mr. Alexander Sinclair. The letter is dated the 10th of March 1845. Dick intimated that he was about to send off from Thurso to Leith, by the "Union" steamer, a number of fossil bones for Mr. Miller. He said, "If Mr. M. has seen anything similar to the piece No. 1 , with the triangular knob, all my dreams of astonishing the geological world by something new are in a measure at an end; for 'tis not alone the size of the pieces that I value, but their singularity.

"An acquaintance here has suggested that the piece I have attempted to delineate was the plate that covered the lower half of the Coccosteus; but in this I find it hard to agree, for I have two lower halves of Coccosteus tilted over on their backs, and they are not at all like this strange piece. The lower half of these pieces has no triangular knob at the upper end in the centre of the plate. Nor will it do, in my opinion, to say that per- 
haps the knob and the rib-like processes were separated from the centre plate, and washed away before it was buried, for, to my certain knowledge, they were originally solidly united in one piece, and the knob could not even have been wrenched away without leaving a mark.

"Besides, in these two pieces of Coccosteus cuspidatus alluded to, there is a knot-like bone, with a long stalk at the lower end, and nothing of the same kind in the piece now sent. If this piece, strange as it is, was in reality the lower half of a Coccostcus, Mr. Miller must correct his description when he speaks of it as one plate or piece, save the two small side pieces that 'fill up the angle.' Mr. Miller knows what I mean.

"I am pretty confident that I have got something new to geologists, and for this reason-rude as my sketch of the fish jaws is-Mr. Miller must know them to be the remains of a Holoptychius."

Five days later (15th March) Mr. Dick again writes to Mr. Miller:- "Not a moment shall be lost in sending you by steamer those curious Old Bones. At the same time, I cannot send you one of them - the largest piece -as it was found; but I will send you a cast of it - a stucco likeness of what the huge buckler was when it lay in the bed of the rock, after I had brought it to light after its long entombment."

The fossil fish found by Dick was indeed a discovery. The frontal plates of the Holoptychins measured full sixteen inches across, and from the nape of the neck to a little above the place of the eyes, full eighteen; while a single plate belonging to the lower part of the head 
measured thirteen and a half inches by seven and a half. Dick was rejoiced to find that Hugh Miller valued the discovery so much, and that he complimented him on the results of his laborious investigations.

In the same letter in which he communicated the finding of the fossil Holoptychius, Dick described to Hugh Miller the beginning of his geological studies. He had been long wandering about Caithness, making general inquiries, gathering fossils, finding old seabeaches, and watching the grindings made by icebergs on the rocks; but now he had begun to excavate the rocks, and endeavoured to dissect them so far as he could.

"I never," he said, "wielded the hammer and chisel until last spring-March 1844; and the laying bare of the large fossil (of which I send you the cast, and the remaining fossils) was one of my first exploits. It was about the vernal equinox. The wind blew off the land. A merry sea tripped through the Pentland Firth. The tide was about full. The waves came dashing in on the rocky shore, in long rolling billows, scattering in spindrift.

"I had laid the large plate bare, and was resting in mute astonishment at the size of the fossil-for I measured it with the handle of the hammer, and found it fully eighteen inches in length-when I was roused from my reverie by the waves dashing against my feet. The tide was now coming in! What was I to do? To raise it, stone and all, was impossible, and I feared that it might be damaged or taken away if I left it until 
next evening. There was no time to deliberate. The tide was nearly up to the stone.

"I then attempted to lift it whole out of its bed, little thinking, in my ignorance, of the extremely brittle nature of petrified bones. Alas! the bone broke across! I gave a gasp, and cried 'Oh!' But I set to work and lifted the rest out, and put the whole in my handkerchief. When I reached home they were a mass of broken débris. I managed, however, to put the bits together again, and of these I send you the plaster cast.

"What was it? was it really a Coccosteus, six feet long including the tail? What do you think I imagined it to be? Nothing more nor less than a gigantic King Crab! wanting the tail; eighteen inches one way and sixteen inches the other. I wandered through Buckland in vain, and then believed that it was the upper piece of a Trilobite. But the 'Old Red' dissipated all these fancies.

"I have a piece or two of fossil bone that would puzzle Agassiz himself. They shall all be sent you. Whether you engrave any of them or not, you are on no account to return them. They would never see the light with me.

"I have taken note of what you say, and will endeavour to comply with your kind suggestions that I should make further searches. . . . I have been along the shore once or twice already, and know of a job or two-one of them rather promising-a bone, as long as my finger, is standing out of an impure bituminous limestone, but 
what the bone may be can only be known when it is dug out."

Hugh Miller afterwards refers to the circumstances under which Dick sent him the Holoptychius. He says, "I do not know what the savans of Russia have been doing for the last few years; but mainly through the labours of an intelligent tradesman of Thurso, $\mathrm{Mr}$. Robert Dick-one of those working men of Scotland, of active curiosity and well-developed intellect, that give character and standing to the rest-I am enabled to justify the classification and confirm the conjectures of Agassiz. Mr. Dick, after acquainting himself in the leisure hours of a laborious profession with the shells, insects, and plants of the northern locality in which he resides, had set himself to study its geology; and with this view he procured a copy of the little treatise on the Old Red Sandstone, which was at that time, as Agassiz's monograph of the Old Red fishes had not yet appeared, the only work specially devoted to the palæontology of the system so largely developed in the neighbourhood of Thurso. With perhaps a single exception-for the Thurso rocks do not yet seem to have yielded a Pterichthys-he succeeded in finding specimens, in a state of better or worse keeping, of all the various ichthyolites which I have described as peculiar to the Lower Old Red Sandstone. He found, however, what I had not described, the remairis of apparently a very gigantic ichthyolite; and, communicating with me through the medium of a common friend, he submitted to me, in the first instance, drawings of his new set of fossils; and 
ultimately, as I could arrive at no satisfactory conclusion from the drawings, he with great liberality made over to me the fossils themselves."

With reference to the manual labour by which Dick earned his bread, Hugh Miller says-" There is no working man, if he be a person of intelligence and information, however unlearned, in the vulgar acceptation of the phrase, who may not derive as much pleasure and enlargement of ideas from the study of geology, and acquaint himself as minutely with its truths, as if he were possessed of all the learning of Bentley." *

In a subsequent letter, written during the same month, Dick says_-"We have gentlemen-geologists here; but not one of them-though they have been many year's in the pursuit-have a single piece similar to those I send you. They have repeatedly gone down to Thurso East, and returned empty. And why? For this simple reason, that they were afraid to fyle t their trousers!"

Certainly, Dick discovered and elucidated many things which lie hidden from the eyes of common men. His indefatigable industry in the cause of science enabled him to accomplish much more than thousands of men furnished with the best available education, and with ample means and time at their command, had been able to achieve. His was only another case of "the pursuit of knowledge under difficulties."

In a future letter to Hugh Miller he said— "I got your enclosed extract. I will proceed to make you a

* Footprints of the Creator, pp. 25, 26; Ed. 1876. 
map of Caithness. As to the dip of the strata, the geologists are right; but as to the localities of the fossils, they are greenhorns. I have traced all the shores, from Ratter on the east to Drumholister on the west. Some beds are perfect Museums of fish heads and bones. I will send you some coprolites of a size that will make you doubt if they really have been voided by fish. Sometimes I think larger animals must have inhabited the sea of the Old Red Sandstone."

On the 8th of April he writes-" In your outlines of Mr. Rose's lecture, in your last paper [the Witness], I find a more rational view of the probable use of the thick coverings of the animals of the Old Red. Dr. Buckland's scalding theory always appeared to me to be ludicrous, and not in keeping with facts. Thus, in the same strata in which I found the very large plate, there were scattered promiscuously scales of the Osteolepis. You know how thick they are, and you now also know that some kind of animal was covered with mail in some places nearly an inch thick.

"Now, there is no proportion between the protecting fragments of the two creatures; and if Buckland was right in his views, it must have been as perilous for poor Osteolepis to swim side by side with Coccosteus as it would be for a modern dandy to attempt braving the rigours of a polar winter in night-gown and slippers. The heat must have been as speedily fatal in the one instance as the cold would be in the other.

"Snug beneath his impenetrable bone, methinks I hear saucy Cocco laughing at poor Osteolep, and ironically 
saying, 'Poor fellow, how I pity you! Why don't you put on more clothes? You will never be right till you get a thicker jacket to keep out the heat.' 'Well, Cocco,' replies his comrade, 'I am very warm already. This coat of mine is horrid hot, and I do not see how it would mend the matter to put on another!' This would be the proper answer to scalding seas, oceans of hot water, and fish with thick coats to keep out the heat!"

From this time forward Robert Dick sent all the new fossils that he found to Hugh Miller for the purpose of illustrating his books on geology, especially that describing The Old Red Sandstone. He sent numerous specimens of the Coccosteus, the Diplopterus, the Asterolepis, the Dipterus, the Osteolepis, the Glyptolepis, and many other remains of ancient fishes, now found only in a fossil state. In 1845, he sent Hugh Miller the first specimen of the Coccosteus minor, which he had found near Thurso. "It was from one of Mr. Dick's specimens of this species," says Mr. Miller, "that I first determined the true position of the eyes of the Coccosteus-a position which some of my lately found ichthyolites conclusively demonstrate,- and which Agassiz, in his restoration, deceived by ill-preserved specimens, has fixed at a point considerably more lateral and posterior, and where eyes would have been of greatly less use to the animal."

In his future editions of The Old Red Sandstone Hugh Miller found it necessary to make many alterations in the text, consequent upon the observations and discoveries of Robert Dick. In his preface to the third 
edition, published in 1846, Mr. Miller says that he had found it necessary to make a good many additions to the volume, and several alterations in the text, where the statements appeared to require modification.

"I need here," he says, "refer to but one of those modifications; and this chiefly that I may have an opportunity of acknowledging my obligations to the meritorious individual through whose kindness I have been furnished with the data on which it has been made. It was stated in the two former editions that there is a gradual increase of size observable in the progress of ichthyolitic life, from the minute fish of the Silurian System up to the enormous Holoptychius of the Coal Measures, the largest of all the ganoids; and that the Old Red System, whose lower beds border on the deposits of the Silurian fish, and upper beds on those of the gigantic ganoid, exhibited in its various formations this gradation of bulk, beginning with an age of dwarfs, and ending with an age of giants.

"Since the appearance of the second edition, however, it has been ascertained that there were giants among the dwarfs. The remains of one of the largest fish found anywhere in the system have been discovered in its lowest formation near Thurso by Mr. Robert Dick, who, by devoting his leisure hours to the study of geology, in a singularly rich locality, has been enabled to add not a few interesting facts to those previously accumulated truths of the science on which its sounder theories can alone be erected, and who has kindly placed at my disposal his collection of fossils. And the positive 
proof which they furnish has convinced me that the theory of a gradual progression in size, from the earlier to the later Palæozoic formations, though based originally on no inconsiderable amount of negative evidence, must be permitted to drop."

He afterwards refers to the comparatively recent discovery of a gigantic Holoptychius in the Lower Old Red Sandstone of Thurso by Mr. Robert Dick of that place. "It bears shrewdly," he says, "against the line of statement in the text of the book, and it serves to show how large an amount of negative evidence may be dissipated by a single positive fact, and to inculcate on the geologist the necessity of cautious induction."*

* Hugh Miller's Old Red Sandstone, p. 176. Ed. 1875. $6 \%$ 


\section{CHAPTER X. \\ GEOLOGY OF THE COAST NEAR THURSO.}

A Correspondence began between Robert Dick and Hugh Miller, which went on apace. Nothing would satisfy Dick but an early visit from his friend to see the fossils actually lying in their beds. "I have some famous things for you to see," said Dick. "There is a head of Holoptychius, which I have left for you to pick out for yourself. There is a cranial buckler of an Asterolepis, which I want you to see in its proper site. Come, come without delay: there is no end of wonder's here-no end of dead fish. Even the town of Thurso is

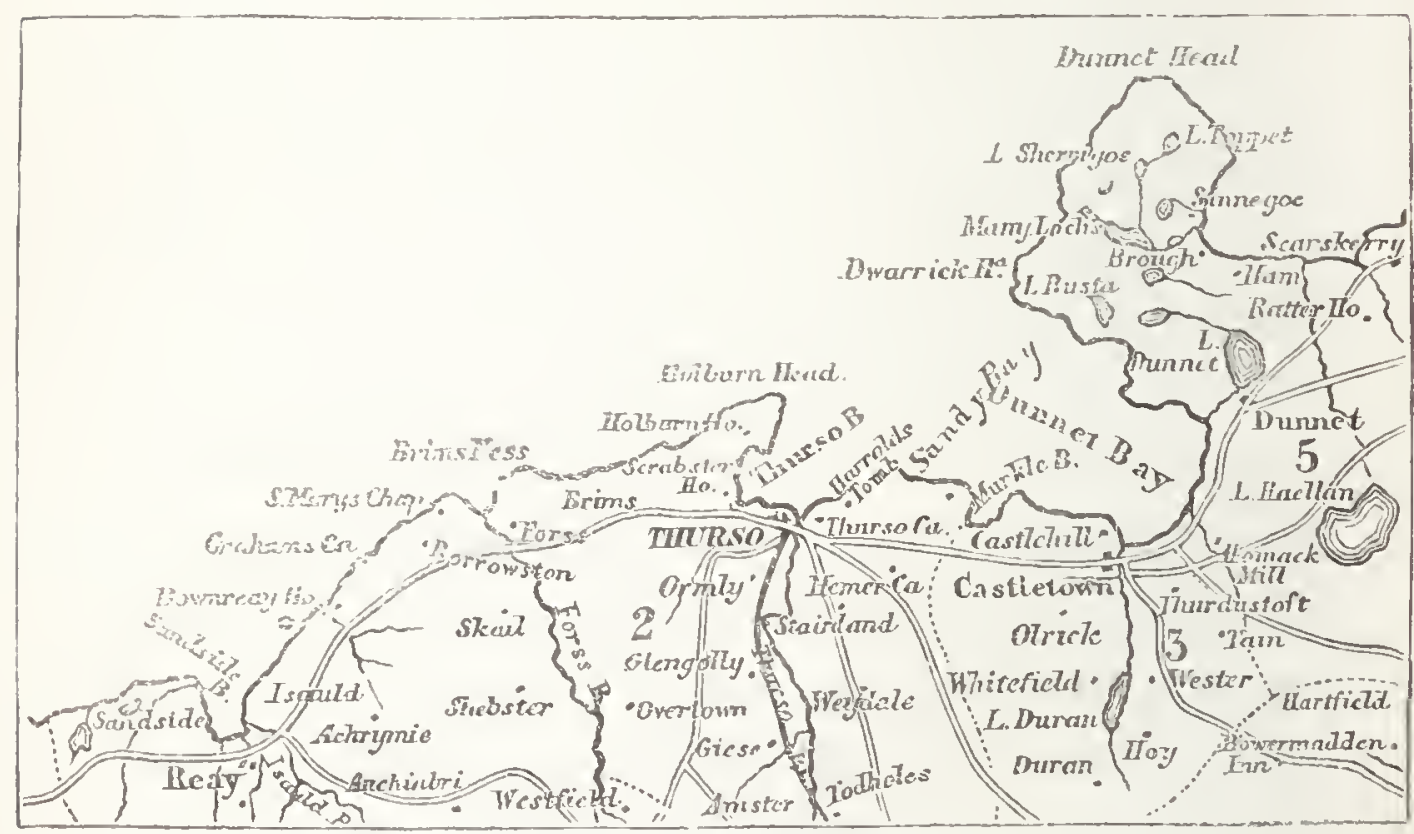


built of dead fish!" In the meantime, to strengthen hi's invitation, Dick proceeded to sketch in words the scenery of the sea-shore at Thurso-east and west of the town. He gave a map in outline of the coast, indicating the convolutions of the headlands and the dip of the rocks.

"Come," said Dick, on the 8th of April 1845, "come, I will lead the way. We shall go round the east shore in the direction of Murkle Bay, and I will direct your attention to a few of the varied peculiarities of our rocky path. Though the tide is at low ebb, we must go round by the bridge, for the wintry spates have driven away the stepping stones across the river....We go on, and are now snuffing the sweet sea-breeze, and through the openings of the land we see the fair blue sea,-rippling bright in the morning sun, and stretching far away into worlds of wonders. Behind us lies Scrabster roadstead. You see the Bishop's Palace, and above it the little burying-ground on the brink of the cliff, sea-worn and ragged, where the echoes of the murmuring waves sing a never-ending requiem to the departed. And there is the old kirk; and there, almost beneath our feet, is the bed of the river. See, there is a nearly horizontal bed of clayey flagstone, highly calcareous and charged with organic remainsscales, bones, spines, snouts of fish, and plants.

"We pass onward. On the beach between us and Thurso East Castle lies a moderate heap of rolled stones of various sizes, and could they be bound together they would form a fine specimen of modern conglomerate. 
"We are now between the castle and the sea, and look! yonder lie the upper beds, which dip away north and a little west. The underlying beds are beneath our feet, for the tempests of many years have washed away the upper surfaces at high-water mark; but the underlying strata do not dip in the same direction as the overlying, but nearly west, in fact a little south-west. How is this? Were the edges of the underlying beds turned up before the upper were thrown down?

"We go on for about a gunshot, and come upon a noted fault. We tread on the edges of the strata, which dip apparently due east or north-east. Forty-eight paces farther on we meet another fault. The strata here appear to dip west. We tread again on the edges of the strata. How is this? These are the underlying beds. The cliff is from eight to nine feet high, and look! yonder lie the upper beds, which stretch unbroken out to sea. The lower beds are highly charged with organic remains, and so are the upper. The latter is bituminous and calcareous, and here I find stout bones, droppings, scales of Holoptychius, and plates with warts on them.

"We come to a bit burnie-a little brawling noisy thing in the month of April. We step across, and are now on firm rock, highly calcareous,-a rude, ill-cemented, cross-grained piece of stuff, which, in some places, reminds me of the riddlings of lime. As we pass on, the fossiliferous beds are on our right hand and on our left. They are not all 'calcareous flag beds,' as described by Murchison. Indeed, none of them resemble the ordinary flags which are sawn into pavement. They are more 
bituminous. And see! here is a bed of highly siliceous stuff, and there is one of green clay, slightly sandy. On taking a decomposed piece in the hand, and rubbing it between the fingers, it feels greasy.

"We are now among the low reefs, and look! there are multitudes of b]ack, brilliant, quadrangular scales, and numerous remains of fish,-snouts innumerable, scales of Holoptychius, pieces of fish jaws, teeth, spines, bones, warty plates, and even plants. A little round the point, almost in the line of a fault, under a rock, I found that enormously big plate [of the Holoptychius], thirteen and a half inches across.

"While occupied in belabouring the rock to dig it out, I was so meditative and so wondrously affected, that some 'town bodies,' not understanding my object, looked down upon me, and speaking to each other said, 'That man is mad!' But I was not so mad as they thought me to be.

"The dip is nearly north, and the fossils are most abundant in the beds of rock close in with the land. I march on over the remains of departed days, and meditate among the tombs of deceased millions of living creatures,--tombs such as Hervey never dreamt of. As I proceed, I pass successively cliffs innumerable, faults innumerable, fossiliferous beds innumerable; for they occur in detached patches, and are to be seen on the very brink of the precipice. The sea is now dashing its billowy spray unceasingly, and along the outer edge of the breakers the crested cormorant and spotted diver ply their ceaseless vocation. 
"The cliffs are now about forty feet high. The bituminous bed underneath is charged with the remains of fish. I used to wonder how the bed here, after running fifty paces or so, suddenly became much harder and highly siliceous. The sea has worn it into ruts-deep ruts - and the remains of fish can be seen peeping out of the sides. There are numerous fossil plants here.

"On we go, and soon tread upon a highly siliceous bed, very rugged, and worn into many strange shapes and gnarled knots. A little after, we pass a fossiliferous bed, charged, as usual, with fragments of fish. In a short while, we meet something like an abrupt wall of rock stretching across the path, over which we must climb. Once up, we find that the sea, which has told on every bed we have hitherto passed, has made no impression here. A highly siliceous bed stretches from the land in a long slope, sheer down into the waves, nearly as entire as it was thousands of years ago, when the real red sandstone beds-once continuous across the Firth from Orkney to Caithness-lay upon it; and though the billows break at every tide with tremendous force, the siliceous bed seems to lie as firm and unworn as ever. The wildest north-west winds that ever blew, and all the rushing force of the dashing waves, have availed but little in shaking the foundations or even abrading the surface of this hard siliceous rock.

"No bed similar to this - neither on the east to Castlehill, nor on the west to Reay-is to be seen at this part of the coast. The beds have everywhere been broken down, more or less. 
"It is with a feeling of enjoyment that the ardent admirer of Nature contemplates the surrounding prospect. The view is grand! On the right is Dunnet Bay, with a schooner or two in the offing, beating up the Pentland Firth. Then there are the red cliffs of Dunnet Head. In long perspective, adown the Pentland Firth, we see the white waves chafing the island of

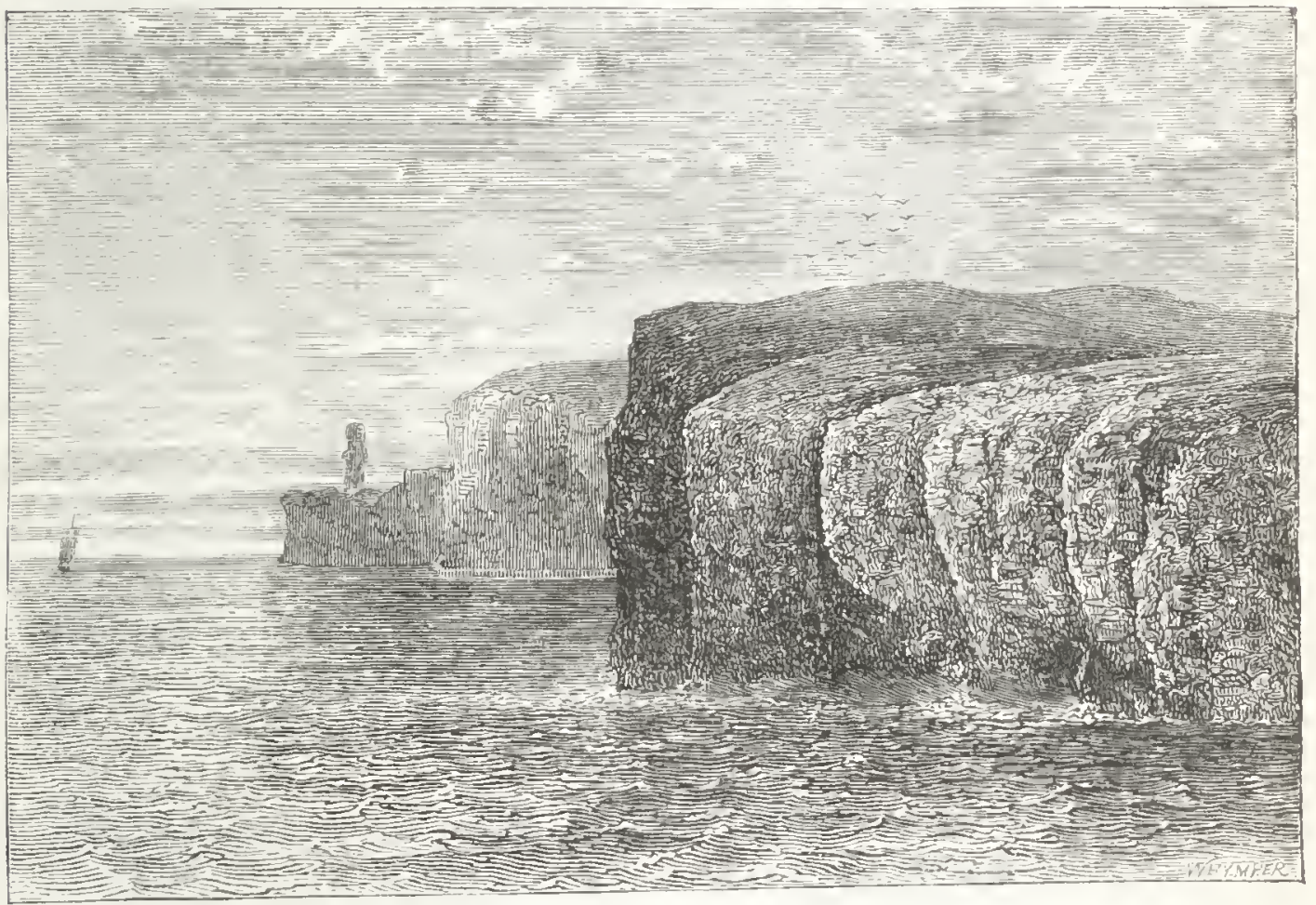

HOY HEAD AND MAN OF HOY.

Waas; and right over, in solitary state, the swelling Orkney liills and the Man of Hoy close the distance. Westward we look over the wide main, no land between us and the coast of Labrador. To the left, along the land, we see Holborn Head and the bay of Thurso, - a complete panorama.

"We go on, and pass fossiliferous beds, when we are stopped by a deep gully worn by the waves, over which 
it is impossible to leap. We therefore climb the cliff, and pass along the grassy bank on the top. The rocky beds there assume varied appearances; faults in abundance; here an opening to the sea, there an irregular wall; until we reach Pudding Gyoe, where the cliffs are steeper, and the sea comes closer in.

"Pudding Gyoe is a hollow cave, worn into the solid rock by the ceaseless grinding of the sea. The entrance can only be seen when the tide is at low ebb. The water from above percolates through the strata, highly charged with lime, so that, in creeping through the rocks underneath, it has formed a stalactitic covering, not unlike the entrails of a cow, or cow's puddings, and hence the name of Pudding Gyoe.

"There is an old tradition of a piper who ventured 'too far ben,' and ultimately lost himself; and many people, good people, heard him long long after, playing his pipes in a low hollow sound, some four miles up the country.

"The beds have hitherto been dipping northerly; but at a small distance farther on, a range of rocks dips east; then there is a most notorious fault. The strata drop down almost on end, dipping east. You then enter Sandy Bay.

"On the farther side you come to more fossiliferous rocks. The remains are invariably the same-quadrangular scales, scales of Holoptychius, snouts of Diplopterus, teeth, warty bones, and some other large bones."

Dick resumes the subject of the above ramble along the north-eastern coast on the 29th of April 1845. 
"On leaving Sandy Bay and moving eastward in the direction of Murkle Bay, the strata continue to dip northerly. We shortly come upon a fault, when a total change in the direction of the dip takes place. It is now nearly due west. We tread upon their upturned edges, and are soon involved in the mazes of a wilderness of broken rocks. Stones of every shape, size, and description are lying around, as if a multitude of men had been at work with sledge hammers, and left the place a scene of the rudest confusion.

"The truth is, the sea rolling in winter and summer across the strata, in placid or in sullen majesty, or in whirling or dashing storms, has broken but not removed this mass of stony wreck. It is, nevertheless, a noted phenomenon of the scenery.

"Murkle Bay owes its existence to a noted fault, and, in my opinion, every little inlet or bay along the coast is due to the same cause. In moving round the sandy shore, the explorer has time to muse on the sandstone cliffs of Dunnet, now distinctly visible across the waters; and the dip of the yellow cliffs can be seen to have the same general strike as the calcareous, and the other beds of clay he has just left.

"At the eastern inner angle of Murkle Bay the strata are in great confusion-bent, twisted, contorted, and dipping in various directions. Moving on a little farther, they assume the usual appearance of dipping away in the direction of Dumnet Head; and here, for the last time in this direction, the explorer detects a bed of bituminous calcareous slates, full of organic remains. 
They crop out between two dissimilar beds, and many warty and other bones are to be found here." . . . .

Dick then proceeds onwards to Dunnet sands and Dunnet cliffs, which have already been described. During the same evening on which he begins the above description, he proceeds to geologise on the west shore of Thurso. He says :- "Shouldering an old poker, a fourpound hammer, and with two chisels in my pockets, I set out for the burn of Scrabster. After a great deal of hammering, I found no end of young Coccosteus. I might have filled a barrel with them, but they were all broken. What hammering! what sweating! Coat off : got my hands cut to bleeding. Found a very hard bituminous bed. It rings like a piece of metal. What pokering! Got three or four fish, not much worth. Don't think them new. Found a plant. Found scales of Holoptychius. Wrought on till the moon shone clear in the water of the burn. Returned home at twenty minutes past ten."

The correspondence between Robert Dick and Hugh Miller proceeds. Dick tells his correspondent of all his findings of fossils. Everything he collects is immediately sent to the Witness office at Edinburgh. Dick had many wanderings for the purpose of finding the richest fossil districts near Thurso before Hugh Miller's visit. Having described the sea-shore to the east of Thurso; he next proceeded to describe the sea-shore to the west of Thurso. He begins his letter of the 4th of May 1845 by quoting the stanza from Byron's Childe Harold, beginning- 
" "He that has sailed upon the deep blue sea

Has viewed at times, I ween, a full fair sight.'

"Such," he goes on to say, "is Byron's beautiful description of a scene at sea; and such has often been my own feeling, when, at evening's hour, my steps have measured the beach that lies spread out so temptingly fair between this little town and its beautiful bay. For, 'tis not unusual, in the month of May, to observe, out in the Firth, some eight or ten large vessels with 'every white sail set,' 'curling the waves before each dashing prow.'"

But Dick had not gone down to look at the beautiful bay and the passing ships, or at Dunnet Head and Hoy Head, with the setting sun glinting along their sides, throwing out their rocky projections, and leaving their hollows and gyoes in the shade. No! He had gone down to the coast "geologically bent." He wandered westward on the sand and then on the rocks, hammer in hand, ready to strike a blow, or any number of blows, for the honour of science.

"Passing on," he says, "I walk over a bed of loose sand smoothed and levelled by the tide, and after a time I reach the solid rocks, of a bluish-grey cast, and dipping northerly, with a little of west. The first beds I meet are not decidedly fossiliferous, though a few scales and droppings may be found. A little farther on I see some warty bones, and still farther, there is a bed decidedly charged with organic remains. Pieces of fish jaws, bones, and tail-half plates of Coccosteus, are seen in considerable numbers.

"Moving on, I reach an opener space, strewed with 
fragments of a dark blue flag, charged, more or less, with organisms. Some very fine fossil fish have been found there. I next come in sight of the human burying-ground on the top of the bank, as distinguished from the fish burying-ground on the rocks underneath.

"The family to which the burying-ground belonged, though once numbering among the Caithness aristocracy, have experienced a sad reverse. The last of the race is now toiling for his bread in a foreign land. Yet, one cannot help heaving a sigh in passing, to think that through his follies and imprudence, the dust of his fathers should be exposed to the contempt of passers-by. The door of their sepulchre is battered to pieces, and the ground is overspread with dank nettles and hemlocks, and other abominations.

"It must surely have been a refined, a poetic feeling, which prompted the founder of the burying-ground to pitch it in such a spot,--close by the murmuring seathe image of eternity. He thought to have slept in undisturbed security. Yet the sea is already undermining the graveyard, and it is not improbable that the rock on which the family vault stands may itself be washed away, and the dust of the dead be driven hither and thither by the wasting and unfeeling waves.

"A little past the burying-ground, and on the beach, I find a change in the dip of the strata. The beds dip east, though almost immediately thereafter they return to their former dip-namely northerly, with a little of west; and continue so until we arrive at the Bishop's Palace, where yellowish, whitish, and striped beds of 
sandstone prevail. The beds ou which the ruined palace stands are reddish and yellowish looking, and dip in the same direction.

"The ruins of the palace occupy an interesting spot.

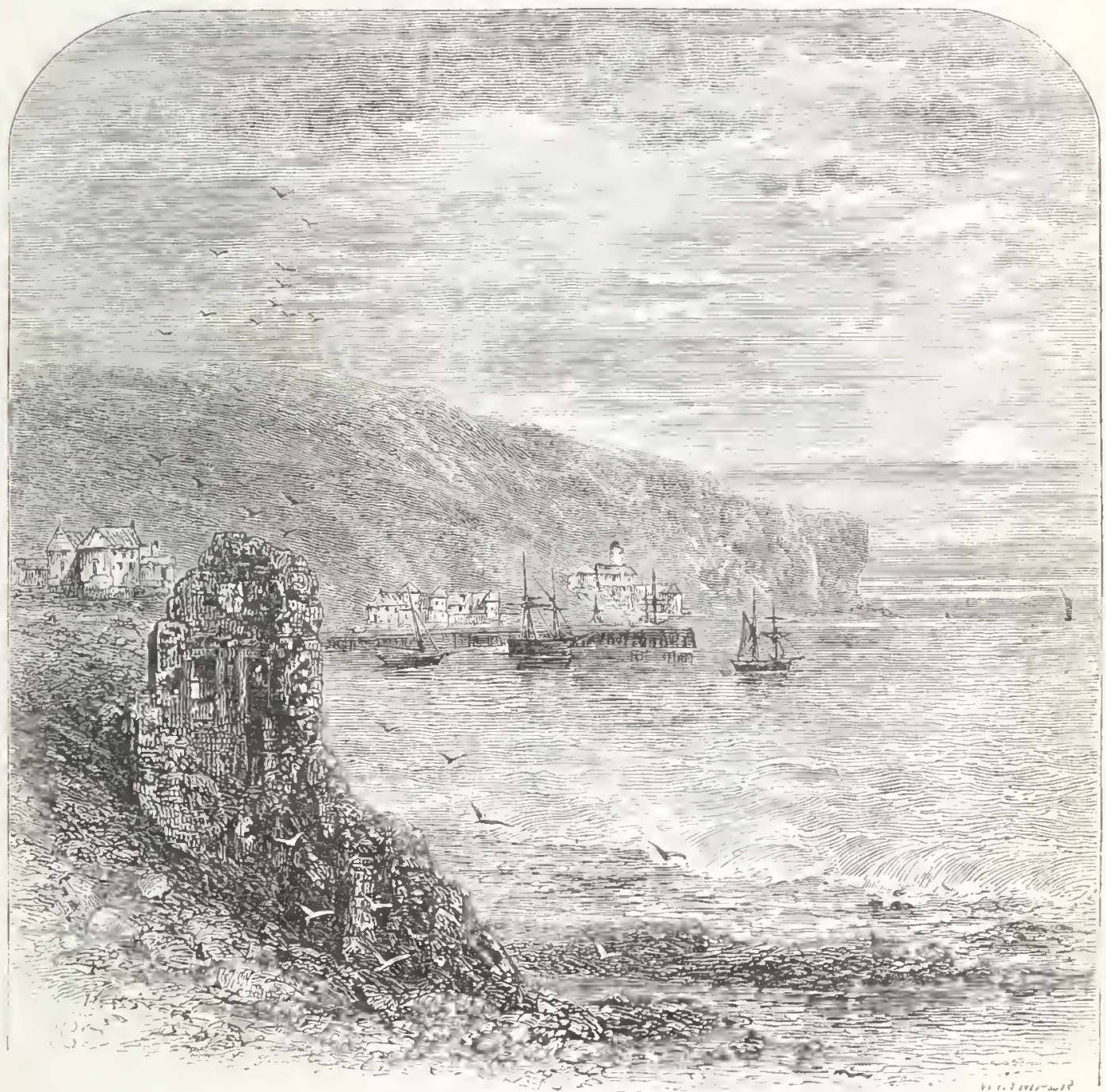

RUINS OF BISHOP'S PALACE AND SCRABSTER ROADS.

It must have been selected by one possessed of a true relish for the beanties of nature. On the south-east side you observe a wide circular hollow of land, swelling gently up to the heath-clad hili of Forss. The headland, running round towards the north, breaks the force of the western storms. On the east there is a series of 
swelling uplands. Looking seaward the prospect is grand. Towards the north, the Orkneys are seen in the distance, with the Man of Hoy standing out to sea. Nearer, Dunnet cliffs are observed boldly fronting the Pentland Firth; and the eye aches in its inability to penetrate the mystery beyond.

"I can well imagine the warm, sunny, summer evenings of bygone days, when the bishop would sit watching the rippling waters, or gazing at the last beams of the setting sun, going down behind the world of waters in a blaze of crimson and gold!

"Sixteen years ago, I remember making an attempt to explore the inner recesses of the ruined palace. I entered the cave underneath with a lighted candle; but I found it utterly impracticable to make my way without pick and spade. There is a low door, which seems to lead to subterraneous chambers; but the passage is choked with rubbish.

"The little burn of Scrabster runs round the rock, entering the sea at its north-west side. The water would be useful to the castle inmates. I have sometimes seen sailors ashore filling their barrels there.

"Close beside the burn, a ridge of clay occurs, and sweeping round Scrabster Bay it rises in some places to about a hundred feet. It is blue and full of stones of various sizes. I have often been astonished at its appearance, and wondered where it could have come from. Some call it boulder clay, and say that it is similar to what skirts the base of some of the Alpine mountains. It may be a Moraine. It seems to fill an irregular 
hollow. The bare rocks are through the soil on the hilltop, immediately behind. Can it really be that those hill-tops, now so insignificant, once towered above the clouds, capped in snow, bound up in ice, and that they have gradually mouldered away down to their present elevation of a few hundred feet above the level of the sea.

"Low down, at the Coastguard house, beneath a weight of clay, the strata crop out, and are at first slightly charged with organisms. A little farther on I find beds charged with warty bones; and the strata dip northerly. Then there is a fault, the strata are in confusion, and dip westerly. They then become nearly horizontal, and continue so until the extreme end of Holborn Head; where I find them slaty, and highly calcareous, bituminous, and containing many remains of fish.

"There is a noted fault to be seen almost atop of the point of the promontory. The strata slope in different directions. They are bent, twisted, contorted, and in great confusion. At one place, they are quite on end. What a subterraneous convulsion there must have been here at one time!

"We pass along, and walk over the Deil's Brig. The sea washes underneath. It is one of the great goes, or gyoes, which abound along the coast. In stormy weather, the sea drives into it with overpowering force, and sends clouds of spray far inland. The Brig clearly shows the hard clay-flag of which the headland is composed. 
"Then we come to that very singular rock, THE CletT. Who, in reading about Caithness, has not heard of Thurso Clett? In fact, it is our great lion. The Clett is an oblong rock of calcareous slate of about 100 feet high. It has been separated by the action of the sea from the adjoining mainland. It is the resort, in summer, of innumerable sea-birds, who breed on the ledges of the cliffs. When sitting on end, in rows, they have not inaptly been compared to rows of bottles in an apothecary's shop.

"Passing on, the cliffs begin to rise until we reach a monument of white sandstone, erected to the memory of Captain M. A. Slater, who, it is said, either fell down or threw himself down the precipice, and was never afterwards heard of.*

"A very little past the monument we meet a kind of a ditch, with a very little water trickling over the slates at its bottom. In these slates are fish; fish without end, but very rotten. Going on a little farther, we come to a spot of rocks washed bare by the wintry storms and the dashing sea-spray. There we find a patch of calcareous slates full of fish! The flags are for the most part much decayed; and the fish themselves have long been dead and decayed, and their scales and head bones had lain scattered about, ere the limy mud and dust wrapped them up.

* It is said that the monument is a sham. The horse on which Captain Slater was mounted, galloped back into Thurso without its rider; but it is said that Captain Slater was afterwards seen in Australia. Jealousy was at the bottom of the affair. 


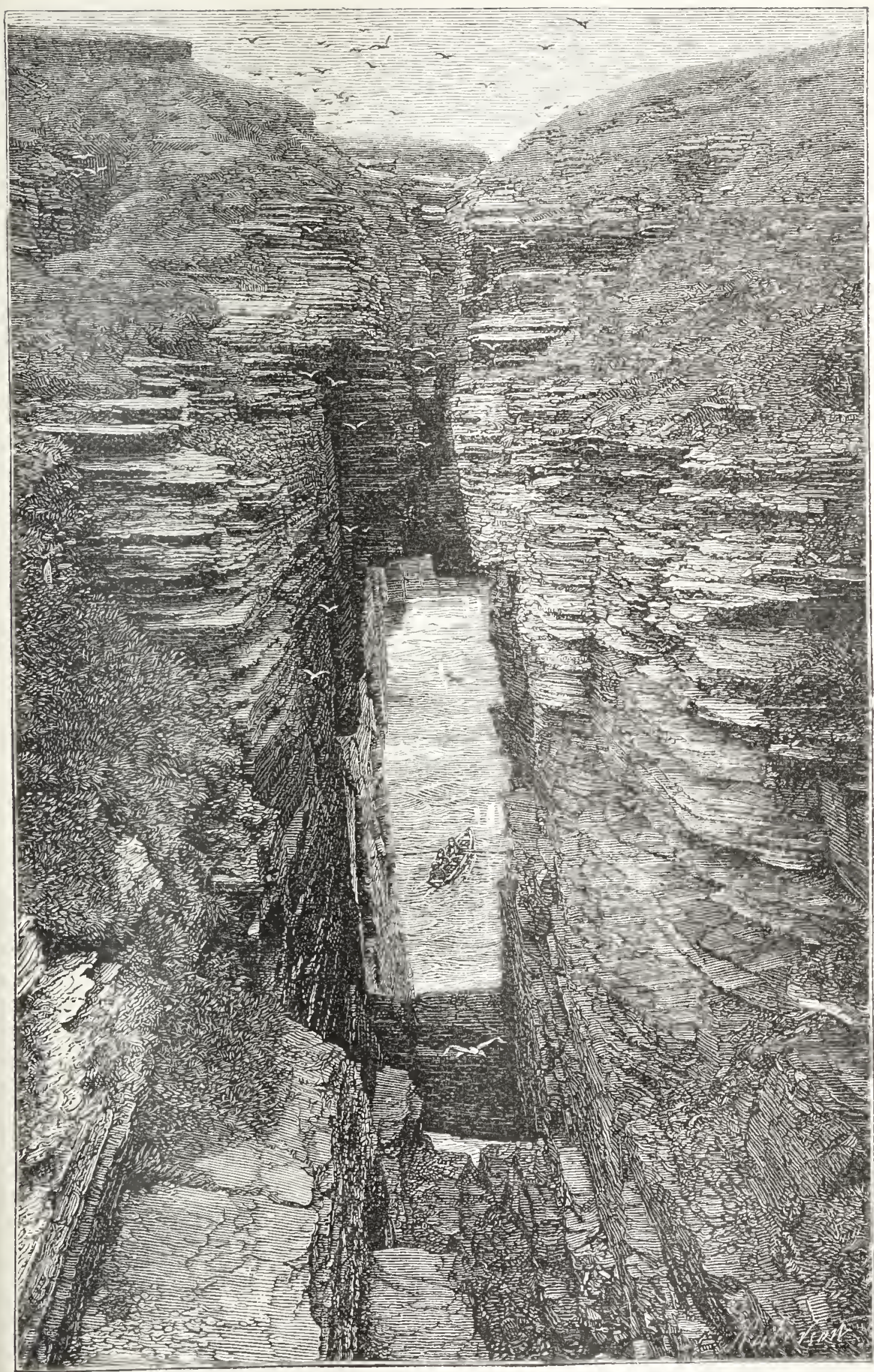

THE DEIL'S BRIG: HOLBORN HEAD. 

"This fish bed reminds me very much of the fish bed at Weydale, a few miles south of Thurso. The fish are of the same species. I remember very well hiring a flagman, and toiling with him half a day, and all that we gathered was two fossil fish out of some hundreds of broken worthless stuff.

"Beyond the ditch the cliffs rise again, and continue of the same height-about 190 feet; and then they swell up suddenly about ten feet more, into a sort of round hill. From thence the cliffs gradually fall, and slope away down to Brims. Before arriving there we find a bed of calcareous slates, of noted appearance, full of the remains of fish, snouts of Diplopterus, jaws, scales, and warty bones. Westward of the house of Brims, there is the same appearance of fish remains amongst bituminous rocks.

"The strata west of Brims are well worthy the inspection of the geologist, on account of the very extraordinary position many of them assume. Their appearance is singular in the extreme."

Holborn Head, and the rocks beyond, continued to be a favourite haunt of our geologist. He not only haunted the top of the cliffs, but by a difficult and dangerous path descended to the rocks underneath them. He resolved that nothing should remain concealed where the pick and chisel could reach them. "Determined," he says, in a letter addressed to Hugh Miller, dated the 6th of May, only two days after the above inspection, "to put down nothing but what I had seen with my own eyes, I started this evening at seven o'clock; and 
walking double-quick time, I reached the extreme point of Holborn Head at a little after eight. By this time the sun had set, and I felt it cruel cold. But I had scarcely set my foot upon the bare slates ere I picked up a very stout piece of fish bone, about seven inches in length. I also found a warty bone, a piece of fossil wood, a scale of Holoptychius; and I left two pieces sticking in the flags until to-morrow, when, if I can, I will hammer them out. These will be sent to you, not so much for their value, as because of their being found at the extreme point of the promontory. . . . And yet I was told by Mr. Manson that nothing was to be got there."

On the 12th of May following, he proceeds-

" "T.o the regions of the dead

Long and painful is the way!'

"I have thought that this ought to be reversed, more especially in the case of poor geological bone-hunters; for it is not when a man sets out on his journey 'to the regions of the dead,' full of hope and strong in spirit, that he is inclined to feel the way long. No; even though he has 3 pounds of iron chisels in his trouser's pocket, a 4-pound hammer in one hand, and a 14-pound smiddy forehammer in the other; and his old beaver hat filled with paper and twine. Away he speeds-

" "The folk still thinking as before

That Gilpin rode a race,'

Nor does he halt, nor lag, nor look behind, till fairly hammering at the blue slate. 
"But the matter is sadly altered when, after playing for some three hours at Blind Man's Buff, he looks round and finds that the sun has gone down, that a cold wind is whistling along the crags, that 'gloomy night is gathering fast,' and that he finds he must begone! When he looks at the result of his toil, he is forced to sigh at its very meagreness when contrasted with his splendid opening dreams. Then, with a shrug of his shoulders, he trusses up his burden, whistles 'o'er the lave o't,' speeds up the brow of the hill, and sees before him the six or eight miles that he has to walk between him and his home,- - then it is that he desponds, and sighs-

"From the regions of the dead

Long and painful is the way.'

"As intimated in my last palaver, I returned to Holborn Head, and after digging out the two pieces of bone left by me on the previous night, I explored a little longer, and found the pieces of very stout bones sketched on the other side. [Six pieces of fossil bone are sketched in pencil-one is the 'tail half of the Coccosteus,' two are warty bones.] These are all taken from the point of the promontory. I think they must have belonged to some very large fish, similar to those which had the very thick skull-caps, found at Thurso East."

With respect to the cliffs of Holborn Head, he says"They are rugged and fearful-looking in many places. They are hollowed out by the winter tempests. The whole force of the North Sea breaks in violently upon the rocks, while a strong tide runs continually either 
east or west. So that one might almost prophesy death and ruin to Holborn Head. In that case, the tide must rise considerably higher in Thurso, for the Head has a great effect in turning aside the flood, and throwing it back into the open firth.

"Fearful as the crags seem, there is a possibility of getting down at one particular spot. I have been down there. I intend to go down again. I should be enraptured to find a fish head in such a place, or even a piece of jaw." 


\section{UHAPTER XI.}

HUGH MILLER VISITS DICK.

RoBert Dick, by dint of continuous industry, was gradually acquiring a notion of Caithness geology. His knowledge was for the most part derived from direct personal observation. He never accepted a statement without having verified it himself. He saw with no man's eyes but his own; he thought with no man's brains but his own. Thus what he did know was thoroughly exact, accurate, and reliable.

As you proceed from letter to letter, in his communications with Hugh Miller, you see him unlearning his old views and learning new ones. Every ramble throws some new light on the geology of Caithness. He notes down everything that he sees. About the dip of Caithness rocks, his observations are for the most part at variance with the views of his "superiors," his "masters in geology." Nevertheless, he notes down his own facts, and no doubt they will by and by be confirmed and adopted.

He was very cautious in adopting conclusions. He must first be quite sure of the premises. He found many writers on geology starting with a theory and then making the so-called facts fit into the theory. "Here has 
been some one writing upon the geology of Caithness," he said. "His writing is very good, but his premises are incorrect. He camnot have seen the rocks, except from a gig, when he passed along the road; and now he drags them in to elucidate his theory. When I want to know what a rock is, I go to it. I hammer it; I dissect it. I then know what it really is. I object to this eternal theorising. My idea is that we know very little of geology, yet these men have got it dignified by the name of a science. The science of geology! Why, don't they see that there are only a very few exposed rocks which we can study. It is only a small bit of the crust of the earth that we can inspect. What are the rocks that we can see, compared with the immense mass lying underground, or forming the ocean bed, which we can never see? No, no; we must just work patiently on, collect facts, and in course of time geology may develop into a science."

Dick even found that some of the fossil fish and fossil branches that he had found in the course of his investigations were turned against himself. He had sent a fossil branch, which had been found in a Caithness quarry, to a friend in the south, thinking it to be of value. He was afterwards surprised to find an engraving of the fossil branch given in a geological publication, with an amount of letterpress, arguing out a theory which Dick had expressed himself as decidedly opposed to. Not only was the theory incorrect, but the fossil was misengraved, having received additions which were not warranted, and illustrated by sections which 
in his opinion were impossible. In short, it was twisted, like many a fact, to suit a theory, and Dick was indignant that a fossil furnished by himself should be used for such a purpose.

It will be observed that Dick's first study in geology consisted in observing the dip of the strata round the Thurso coast, from Dunnet Head to the end of the Holborn rocks. He did this with great care, and indicated the faults, disturbances, and fossiliferous rocks, with their various dips, in the letter he sent to Hugh Miller in April 1845. He found many of the rocks abounding in dead fish, quantities of scales, heads, bucklers, and fossil fish, sometimes in great confusion. Sometimes he found them in abundance on the top of the highest rocks at Holborn Head. How came they there?

This led him into a consideration of the causes of the abundance of dead fish in a fossil state on the shores of Caithness. It was clear that the northern part of the county, where the fossil fish so abundantly exist, had at one time been entirely under the sea. It had formed part of the bed of the ocean. An upheaval of the bed occurred, when or how was not known. The multitude of fishes were caught as in a trap. They were smothered amidst thin clay. They died in agonies. Hugh Miller says- "The figures of the fossil fish are contorted, contracted, curved; the tail in many instances is bent round to the head, the spines stick out, the fins are spread to the full, as in fishes that die in convulsions. The attitudes of all the Ichthyolites on the platform of death, are attitudes of fear, anger, and pain." 
The clay formed, layer upon layer, on the fishes, and was transformed by pressure into flagstones. The process of depression and elevation may have been repeatedly performed, but every elevation brought up from the sea bottom dead fish without end. In fact, the commercial value of Caithness flags consists in the amount of dead fish they contain. "Thurso is built of dead fish," said Robert Dick; "and the capitalists and labourers are also maintained by the same article."

Sir Roderick Murchison says of the flagstones of Caithness, "that they are highly valuable for many uses, and must prove eminently durable from the nature of their composition. Their well-known durability is attributable, in part, to the large amount of bitumen they contain, which has been produced by the abundance of fishes which existed at the time those rocks were deposited, the fossil remains of which still abound. Tar and gas may be distilled from them." Hugh Miller also says -_ "The animal matter of the Caithness Ichthyolites is a hard, black, insoluble bitumen, which I have used more than once as sealing-wax."

But the geological formation of Caithness was still in progress. These dead fishes existed long before the appearance of man on the earth. If we stretch our view over long intervals, it will be found that, in consequence of the depression of one portion of the earth's crust, and the elevation of another, what has at one time been dry land becomes covered with sea; and what has at one time been sea, at another becomes dry land; and that, partly in consequence of the eccentricity of the 
earth's motions, and partly in consequence of the shifting distribution of land and sea, what at one time has been tropical, at another becomes arctic, and what at one time has been arctic, at another becomes tropical.

Astronomers tell us that more than 200,000 years ago, the earth was so placed in regard to the sun, that a series of physical changes was induced, which eventually resulted in conferring upon our hemisphere a most intensely severe climate.* All the northern lands of Europe were then covered with a thick crust of ice and snow. The climate of England and Scotland was what Greenland is now.

Glaciers, laden with boulders, some torn from the rocks on which they rested, some fallen from overhanging heights, flowed down the valleys, leaving their ice-tracks along the sides of the hills. When the glaciers melted, they dropped the boulders which they contained, either on the land, or in the sea, far away from the place from which they had been reft from the rocks. Then was laid down the boulder clay, consisting of an agglomeration of ground-down rocks of various kinds, old red sandstone, chalk, or coal, interspersed with boulders, pebbles, and sometimes shells.

There must have been constantly recurring alternations of climate, from arctic frost to tropical heat, though separated, it might be, by hundreds of thousands of years, before the dry land was prepared for the occupation of man. Again, every bed of coal presumes an elevation of the land, and a subsequent depression. Near New- 
castle, there are numbers of these beds, some of them from eight to ten feet thick. These successive beds of coal consist of the remains of peat mosses, ferns, jungle, cypress swamps, and forest growths. They were either submerged where they grew, or were drifted into seas of deposit. When compressed by the superincumbent strata of sandstones, limestones, shales, mudstones, and ironstones, they formed the coal fields of every country. Then, at last, the present land and the present sea took their places, and man entered on the scene.

Full of curiosity, or perhaps full of the desire for knowledge, Dick proceeded, in course of time, to look into the geologic formations of the ground on which he lived. He dug into the rocks, inquired into the nature of the soil, and found many things which excited his surprise and his wonder. He found many dead things under his feet-dead foliage, dead ferns, dead seaweed, dead fish, the dead remnants of chaos.

Such was the subject on which Robert Dick was now spending the remnants of his spare time. He not only spent his days but his nights in his search for dead objects. He himself was not before the public, but Hugh Miller was. Hugh was the editor of the Witness newspaper, in which he entered all that he knew about geological matters. Accordingly Dick sent all that he discovered during his rambles to his friend at Edinburgh. Here, for instance, is a bundle of his findings, which he sent to Hugh Miller on the 21st of July 1845 :-

"I send a stone, with a fossil fish in it, from Weydale; a stone from the salmon cruives in the Thurso river, with 
a fish on each side of it; a stone from the little buryingground of Pennyland, with a bit of fish on it; a stone from the burn of Scrabster, with a fish wanting the head on it; a bone or two from the extreme point of Holborn Head; a fish, a stone or two from the fish-bed, Holborn; and some bits of fish from Brims. Some bones from Thurso East-one, two, three of this form [giving a drawing], and a fragment of a skull-cover of great strength, but not so strong as the monster plate I sent you; but the triangular knob thus

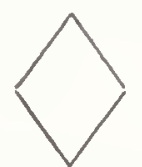
is of such size as fully to confirm you in the faith of my report of last year. The fragment is altogether of a massive appearance. I am much chagrined at my ill luck in not finding a whole fish of respectable size. I am not, however, cast down, but may yet be triumphant."

Hugh Miller received with gratitude the fossil fish sent him by Dick. He also referred to them in his articles in the Witness, and mentioned Dick by name, as the discoverer of the principal fossil fish. Dick had no desire to appear before the public in this or any other way. He was an extremely shy man. Some who did not really know him, thought him morose. But he was nothing of the sort. He enjoyed science merely for its own sake, and it always gave him the greatest pleasure to hand over his fossils to others who could make use of them, and bring them under the notice of scientific men.

Hence, in the letter to Hugh Miller accompanying the above bundle of fossils, he says:- "Your letter, with the 10th and 11th Geological Rambles, came safely 
to hand. That of the 11th arrived this morning.* I turned to it without a moment's delay. I had not read very far when I had a notion of what was coming, and the perspiration began to rise profusely from my brow. ... Seriously, nothing could be better handled than your ingenious mode of broaching the subject, nor exceed your masterly manner of carrying it through. . . Only, like a good man, do not speak so often about me by name. I am a quiet creature, and do not like to see myself in print at all. So leave it to be understood who found the old bones; and let them guess who can."

Dick again repeated his invitations to Hugh Miller to come to Thurso, and see what he had been doing on Holborn Head, in Thurso East, and at Dunnet Head. But in order to explore the country further, he went inland to see what had been found in the flag quarries at Weydale and Banniskirk. He had been to Weydale several times, and made the acquaintance of a quarryman. He had made an appointment to visit him on a certain day, and, as Dick was a most punctual man and kept his appointments to a minute, he accordingly made his appearance at Weydale.

"As I drew near the place," he says, "the auld bachelor came out, pipe in cheek, and sitting down on a stone, he made a motion for me to come and sit down beside him. 'I saw you coming,' he said, 'but I thocht you wudna come the day, it was so blawey.' 'Oh,' said I, 'I always keep my word, blawey or no. Did ye tirr a bit?'t 'No, man,' said he, 'the grun was so 
hard that feint a bit o' the pick wud go through it. The grun's like iron. But,' he added, 'I've got a fish!' 'Have ye?' said I. 'Yes,' he said, ' oot o' anither place. Ye can see it in the barn.' And away we went to inspect the fish in the barn; and there it was, spread out on the clay floor. 'See!' said he. 'O man,' said I, that's grand, it's a new kind' [Dipterus]. It had been much wasted ere it was buried up in the mud; the tail rays were all scattered; the head plates were spread out; but a piece of the body was standing up wonderfully full and round.

"'See,' said he again, 'there's a head!' It was that of a Diplopterus-much broken, but of a good size. 'I must see the place from which it was taken,' said I. 'Come away then.' So, shouldering a pick and spade, away we set. About three good stonethrows from the burn, we came to what some people had been trying to make a ditch-rough and rude-and in the ditch was a rock, and in the rock, fish and abundance of loose scales. But the fish are much wasted. We worked at the place an hour, but did not get one fish that would bear carrying away. We saw plenty of broken Diplopterus. I cut my hand and broke my chisel, and then left the spot, and went back to the burn, where I got a ferw small things.

"If you choose to come here and stay three or four days with me, you can have a fair trial upon a third locality close by, which has never yet been fairly tested. I will make you wolcome to my little house, and you can give Scrabster, Holborn Head, a trial also 
- say a day at each. The Diplopterus is abundant at the Cruives, and Dipterus also."

The quarrymen in the neighbourhood had now begun to learn the value of fossils. The publication by Hugh Miller of the specimens of the Holoptychius, Dipterus, Diplopterus, and other fossil fishes found by Robert Dick near Thurso, had the effect of sending many fossil-hunters into the neighbourhood. It was holiday time--the month of August, - and wherever curiosities are to be found, there is a rush to see them, to find them, and to carry them home as treasures. Accordingly, when Dick went out fossil-hunting, he found the strangers from the south very much in his way. One day in August, before the arrival of Hugh Miller, he extended his investigations to Banniskirk. It was about eight miles from Thurso, and he had never been there before.

"I have been seventeen years in Thurso," he said (13th August 1845), "but never saw Banniskirk. I have been two years a fossil man, but never saw Banniskirk. You were one blessed week there; but what were you doing?

"Eleven o'clock was ringing this forenoon when I left Thurso for Banniskirk. I went on and on until I reached it. Most fortunately I directed my steps to a point of the rubbish which, in my opinion, had not been touched since the first opening of the quarry. The day was cold and wet, and there I stood hammering away, as shower after shower went driving by. I was alike indifferent to wind and weather for some hours. 
"When I had tied up my bundle I went to the upper end of the quarry - a good gunshot off-where four or five men were at work. Accosting them, I said, 'Is there any sign of fish with ye?' 'O no, boy,' they said, 'ye're on the wrong scent. But what wad ye gie for a score o' them?' 'I don't know,' said I, 'what wad ye seek?' 'I got five shillings for one,' said a buck-toothed man with a long nose. 'Ay,' said I, 'the siller has been plenty.' 'Yes,' said another; 'he was an Englishman!' 'Oho,' said I, 'that's the stuff! Nothing like English gold! 'Yes,' said he; 'away wi' yer scabbit Thurso folk!'

“'But,' said I, growing saucy in my turn,-' they're lying in hundreds at Weydale - in hundreds at Holborn Head-in hundreds at Brims-in hundreds at Thurso East!' 'Ay', said they, with a girn- 'FresH Herring!' 'Not so fast,' said I. 'What then?' 'Fossil bones.' 'Not so good as this?' said they. 'Yes, far better,' and then I came away.

"Dirty, greedy vagabonds. I knew them perfectly well. To get a price for a few old bones, they have thrown rubbish on the face of the strata. I had, however, got as many fossil fish as I wanted, no thanks to them.

"I said I had beat you-no harm! Did you meet with any trace of Coccosteus at Banniskirk? or did you meet with any trace of a Holoptychius? I found both. I think, if you had met with any sign of either, you would have mentioned it. The head of the Holoptychius that I found, was about three and a half inches wide; a 
prize from Banniskirk! When I was tying up my bundle, a stone beside me drew my attention. 'A gillcover!' said I. Lifting my hammer I gave it a blow. Huzza! Warty! Coccosteus! Huzza again!

"I had a heavy bundle home; and about eight miles to walk."

Hugh Miller had not yet paid his visit. Dick was eagerly expecting him. He determined to give Hugh a great treat when he came. He would have a number of fossil fish for him to dig out with his own hands. For this purpose he went along the shore, east and ${ }^{\circ}$ west. One day he crossed the stepping-stones at the mouth of the river, and was passing under Thurso Castle, when Sir George Sinclair hailed him. Dick was deaf that day. He had lost a whole afternoon a few days before, by being caught and involved in a conversation by Sir George. Therefore he rushed up the cliff and disappeared instanter.

But he was not yet at liberty. "One of the salmonfishers," he says, "left his employment, and came and walked sentry over me on the brae head. This was annoying, but I pushed on. Then some boys fishing cuddins left their sport and dogged me, tramping almost on my tail. This was horrible. When I threw a stone aside, they impudently lifted it and looked at it. Wherever I went, they went also. I saw the snout of a Dipterus; then two in succession of the snouts of Diplopterus; then a broken skull-cap, standing out for about nine or ten inches, but it is broken,-- for some stupid fool had given it a passing blow-not knowing 
what it was. I saw it and quaked, for the boys were still behind me. I did not betray myself, by look or by sign. Then I got angry, and ran away at my utmost speed.

"Next day was very wet, but as I was eager to know if my bone was safe, I put up my umbrella, and walked over. As I neared my prize, I ventured to reconnoitre. Thief-like, I looked round in every direction, and then moved forward, and found it quite safe. . . . I can now say confidently that you will have the pleasure of digging out the remains of this Holop with your own hands at Thurso East. I am very glad!

"I will next go to Holborn Head, pass Slater's monument, and with a spade turn aside a piece of the clay and turf, that you may have the pleasure of striking a passing blow, and get a fossil fish there, also with your own hands.

"I was at Weydale on the 9th, and managed to "tirr a bit.' The remains of the Diplopterus are there in abundance; but they are very much knocked aboutheads, scales, gill-covers, bits of tails, and such like. I only brought off one moderately passable specimen for you.

"I expect that you will strive to drop me a note, as to what time I may expect you; so that I can have my work snugged, and all in order. I shall be most happy to see you, and we shall have a Glorious Day!'

Hugh Miller at last paid his visit to Robert Dick. They had been corresponding for a long time, but had never yet met. Their meeting was full of cordiality. 
Robert gave up his bed to Hugh, and he was to stay there as long as he liked. But his visit was to be very short. He had very little spare time at his disposal. The Witness must be kept up to the mark; and like many other newspaper editors, he thought that if he remained long away, the world would come to an end. Then, there was his new book to write, the Asterolepis of Stromness. Hugh Miller's first visit to Robert Dick was therefore of only a few day's duration.

The weather was fine, and most of their time was spent out of doors. They walked along the east shore, and along the west shore. First they went with hammer and chisel to Thurso East, to dig out the Holoptychius, the head of which Dick had noted only a few days ago. Dick pointed out the bed from which he had taken the gigantic fossil fish the year before. After this work had been done, the brother geologists proceeded eastward, Dick pointing out the scales and teeth, the tuberculated plates, and the coprolites of the fossil fishes. Hugh Miller afterwards gave a sketch of the coast, of Dunnet Head on one hand, and Holborn Head on the other, with the Orkneys "rising dim and blue over the foam-mottled currents of the Pentland Firth." We have already given Dick's sketch of the same view; and we prefer it, as it was done from the quick.*

But we quote a passage from Hugh Miller's description,-a bit of nature painted by a poet. "We are still within an hour's walk of Thurso; but in that brief hour

* For IIugh Miller's description, see The Cruise of the Betsy, or A Strmmer Ramble among the Hebrides, pp. 181-6. Ed. 1873. 
how many marvels have we witnessed! how vast an amount of the vital mechanisms of a perished creation have we not passed over! Our walk has been along ranges of sepulchres, greatly more wonderful than those of Thebes or Petrea, and a thousand times more ancient.

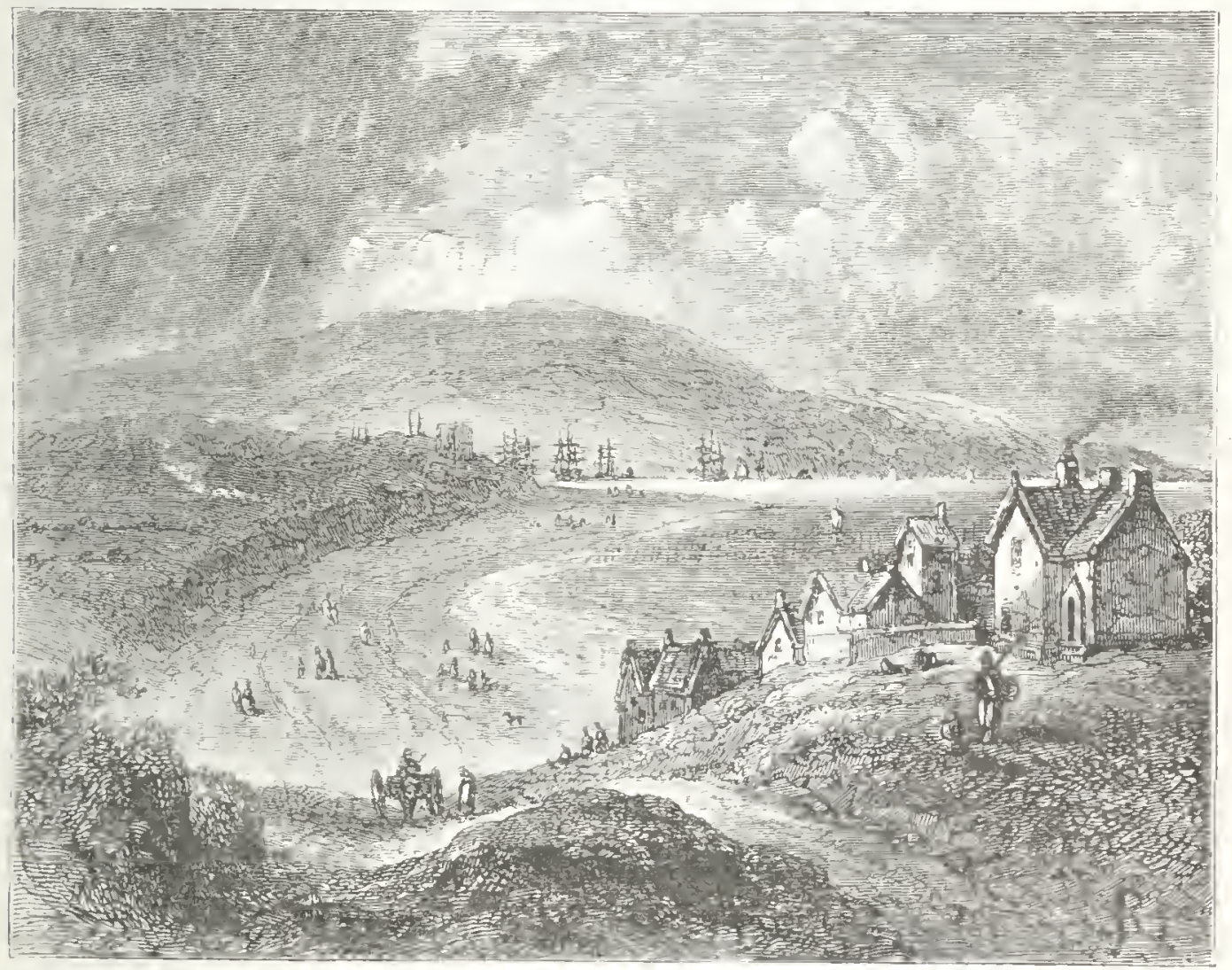

DUNNET SANDS

There is no lack of life along the shores of the little solitary bay. The shriek of the sparrowhawk mingles from the cliffs with the hoarse deep croak of the raven, the cormorant, on some wave-encircled ledge, hangs out his dark wing to the breeze; the spotted direr, plying his vocation on the shallows beyond, dives and then appears, and dives and appears again, and we see the glitter of scales from his beak; and far away in the offing the sunlight falls on a scull of sea-gulls, that flutter 
upward, downwards, and athwart, now in the sea, now in the air, thick as midges over some forest brook in an evening of midsummer."

The geologists passed on towards Dunnet Bay. They crossed Dunnet sands, and at length reached the tall sandstone precipices of Dunnet Head, with their broad decaying fronts of red and yellow. They had reached the upper boundary of the Lower red formation, and found it bordered by a desert, and void of all trace of life. They plied hammer and chisel, but found not a scale, not a plate, nor even the stain of an imperfect fucoid.

On the following day the brother geologists wandered along the shore of Thurso West,-Dick pointing out the boulder clay between the Bishop's Castle and Scrabster Harbour. They ascended Holborn Head, went along the precipices to the Clett, after which Hugh Miller chiselled out with his own hands the fossil fish that Robert Dick had set apart for him. He did not cut his hands as Dick had done, for Hugh was an accomplished mason before he became a geologist. There was one particular sight that struck Hugh very much while standing on the top of the rocks at Holborn Head, and looking down with Dick into the deep sea-green water, underlying the lofty cliff called "Slater's Leap." Hugh Miller' afterwards described it splendidly in his Lectures on Geology. He says:-

"Perhaps the most striking scenic peculiarities of the Old Red Sandstone are to be found in its rock-pieces. The Old Man of Hoy, with its rural rampart of rock- 
pieces, not unfurnished with turret and tower, and wide yawning portals that rise a thousand feet over the waves; the tall stacks of Duncanshy, Canisbay, ornately Gothic in their style of ornament, with the dizzy chasms of the neighbouring headland, in which the tides of the Pentland Firth for ever eddy and toil, and the surf for ever roars; and the strangely fractured precipices of Holborn Head, where, through dark crevice and giddy chasm, the gleam of the sun may be seen reflected far below on the green depths of the sea, and venerable and grey, like some vast cathedral, a dissevered fragment of the coast descried rising beyond,-are all rock scenes of the Old Red Sandstone.

"When I last stood on the heights of Holborn there was a heavy surf toiling far below along the base of the overhanging wall of cliff which lines the coast, and deep under my feet I could hear a muffled roaring amid the long corridor-like caves into which the headland is hollowed, and which, opening to the light and air far inland by narrow vents and chasms, send up at such seasons, high over the blighted sward, clouds of impalpable spray, that resemble the smoke of great chimneys. As I peered into one of these profound gulphs, and dimly marked, hundreds of feet below, the upward dash of the foam, grey in the gloom, - as I looked, and experienced with the gaze that mingled emotion natural amid such scenes, which Burke so well analyses as a consciousness of great expansiveness and dimension, associated with a sense of danger,-my eye caught on the verge of the precipice the outline of part of an old 
reptile fish traced on the rock. It was the cranial buckler of one of the hugest ganoids of the Old Red Sandstone, the Asterolepis. And there it lay, as it had been deposited, far back in the bypast eternity, at the bottom of a muddy sea. But the mud existed now as a dense grey rock, hard as iron, and what had been the bottom of a palæozoic sea had become the edge of a dizzy precipice, elevated more than a hundred yards over the surf. The world must have been a very different world, I said, when that creature lived, from what it is now. There could have been no such precipices then; a few flat islands comprised, in all probability, the whole dry land of the globe; and that emotion of which I had just been compassed, is it not something new in creation also? The deep gloom of these perilous gulphs-these incessant roarings-these dizzy precipices - the sublime roll of these huge waves-are they not associated in my mind with a certain idea of danger-a feeling of incipient terror, which, in all God's creation, man, and man only, is organised to experience? Is it not an emotion which neither the inferior animals on the one hand, nor the higher spiritual existences on the other, can in the least feel-an emotion dependent on the union of a living soul with a fragile body of clay, easily broken?"*

While at Thurso, Miller fired his friend's mind with the injustice done to the poor remnant of the Highlanders who still remain in the far north. Many years before, the Celts had been driven out of their homes, such as

* IJugh Millers Lectures on Geology, pp. 199, 200. Ed. 1869. 


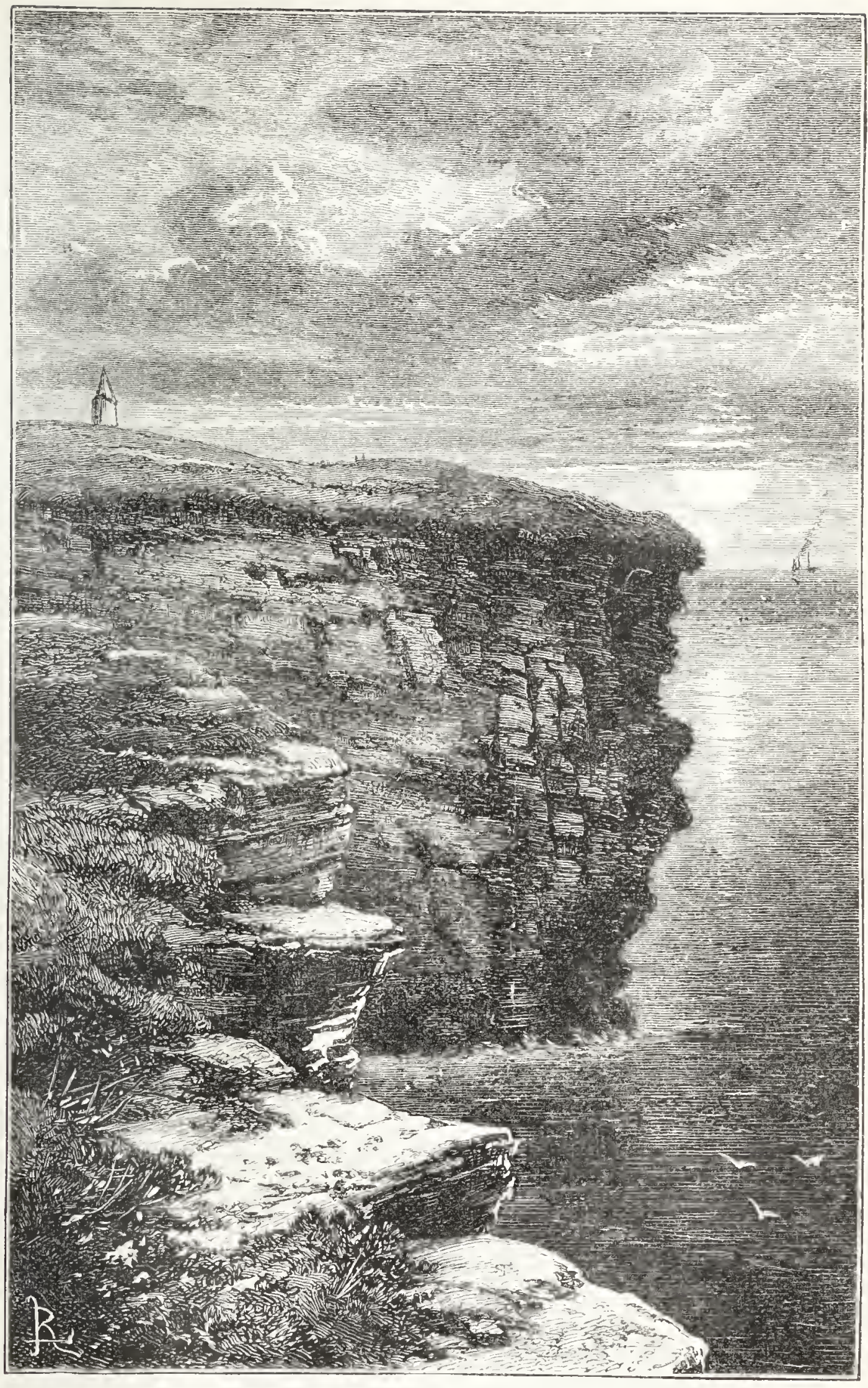

ROCKS AT HOLBORN HEAD: SLATER'S MONUMENT. 

they were, to make room for sheep, and afterwards for deer. This was during the time that Sir John Sinclair was so much bent upon introducing the Cheviot breed of sheep into Scotland. The Highlanders were thought to be idle, and they were accordingly driven away, or forced to emigrate. It was thought to be "for their good."

Yet the poor folks did not think it for their good to leave their homes amongst the hills in which they had been born. But the law was against them. The chiefs insisted on their pound of flesh, and the Highlanders were expelled, and emigrated in all directions. If they did not leave after their notices had expired, their houses were pulled down, and sometimes they were burnt down, leaving only blackened ruins. One old paralytic woman was actually burnt in her bed.

In 1795, Sir John Sinclair raised a regiment, the Caithness Highlanders, consisting of 1000 stalwart men. No such regiment could be raised now. The Highlanders are now in Canada, and sheep supply their places. Emigration still continued to go on. In 1841 Dick wrote to his sister: "Emigration to America is fast thinning the moors of this cold bare country; and soon, very soon, it will be bare of population with a vengeance. Two ships have already sailed. A third and a fourth are expected to sail this season. Many hamlets have been pulled down, and those that have not been pulled down are to let!" The flag works at Thurso, and of Mr. Traill of Castletown, gave employment to many of the expatriated clansmen; but still, 
there were thousands preparing to set out for Canada and America.*

The trouble was renewed in another way when the Free Churchmen dissented from the Established Church. They could not find sites for their chapels, and sometimes they gathered together on the verge of a loch, where the minister could preach to them from a boat. They also assembled in the open air, along a hill-side, or in a valley surrounded by rocks, where the minister dispensed to them the Word of God and the Holy Sacrament.

Hugh Miller was editor of the Witness, an outspoken paper, the organ of the Free Church. Hugh was a great power in those days. He was one of the boldest writers of his time. His paper spread far and wide the cruelty and injustice of the Highland proprietors. Here is one of his descriptions, which he wrote while on his way to meet Robert Dick at Thurso :-

"I have just returned from Helmsdale," he said, "where I have been hearing a sermon in the open air with the poor Highlanders. . . . I thought their Gaelic singing, so plaintive at all times, even more melancholy

* On the 2Sth August, 1846, an Act was passed enabling a loan of two millions to be advanced to the landed proprietors for the drainage and improvement of their cstates. The loan was soon exhansted. The Highland lairds got the lion's share. One of them, Macleod of Macleod, asked for an incredible sum, so that it became necessary to limit the maximum amount of the loan to individuals, to $£ 5000$. By the Act 13 and 14 Vict., cap. 91, a further sum of two millions was granted for draining purposes; but it was found that a quarter of a million of the money had been spent, not in draining the soil of North Britain, but in clearing out the Highland population from their miserable huts, and transporting them to the British Colonies! 
than usual. It rose from the green hill-side like a wail of suffering and complaint. Poor people! There stretched inland, in the background, a long deep strath, with a river winding through it. It had once been inhabited for twenty miles from the sea; but the inhabitants were all removed to make way for sheep; and it is now a desert, with no other marks of men save the green square patches still bearing the mark of the plough, that lie along the water-side, and the ruined cottages, some of them not unscathed by fire, with which these are studded. ... The people had a look of suffering and subdued sadness about them that harmonised but too well with the melancholy tones of their psalms. There is, it is said, a very intense feeling about them. 'We were ruined and made beggars before,' they say, 'and now they have taken the gospel from us."

And again, at Loch Brora, he says:- " The Loch stretches out in front for miles, its undulating and winding shores tufted with birch, and here and there mottled with small green spots that, ere the poor Highlanders had been driven from home, kept them in oats and bere. ... I doubt not that the thoughts of them live, set in sorrow, in hearts beyond the Atlantic."

When Hugh Miller had left Thurso for Edinburgh, Robert Dick took his pen in hand, and wrote the following stanzas :-

\section{DONALD'S FLITTIN !}

Eh, Donald, man, they've served ye sair,

Yeer Hieland chiefs an' a',

'They've brought their sheep, an' nowt, an' deer,

And ye maun gang awa! 
Ye focht for them, ye bled for them,

Sae lang's a sword ye'd draw, An' though ye got but little for't, Now ye maun gang awa'

Puir Donald, man, where is he gaun ?

His wife and bairnies twa?

"Oh, fient care I," the laird, said he, "So that they gang awa"!"

The wife sat by her cauld hearth-stane,

She couldna thole her fa';

She moaned and sighed, anci groaned and grat, She wadna gang awa'!

The licht was set to theek and roof,

The fire ran up the wa'!

Alas! the Hieland mother now

Was forced to gang awa'!

Oot owre the cot, upon a stane

She sat, wi' bairnies twa ;

Her heart was brak, she couid but dee ;

She couldna gang awa'!

$\mathrm{He}$ couldna use his dirk the noo,

The laird was right in law ;

Sae Donald gave up house and hame,

And syne he gaed awa'!

Across the seas he dreams o' hame,

Far off in Canada ;

But grim and bitter Donald thinks

Of when he gaed awa'! 


\section{CHAPTER XII.}

\section{DEATH OF DICK'S FATHER-THE BOULDER CLAY.}

IT will be remembered that Thomas Dick, supervisor, left Thurso in 1834, shortly after his son Robert had begun business as a baker. Mr. Dick was appointed to the office of Collector of Customs at Haddington. He did his duty there in a quiet, unostentatious manner, and gained the respect of everybody who knew him. After his term of service had expired, he removed to Dovecot, Tullibody, where he ended his days in peace and quiet.

Robert Dick continued to keep up a correspondence with his father, though none of his letters have been preserved. The last letter of his father (22d April 1846) informed Robert of his last illness. "My complaint," he said, "is in the heart. I am sometimes alarmingly ill. At other times, though very weak, I am able to be up. . . . There is no prospect of my recovery. I have been preparing for the last change, and have laid my hope on the Lord Jesus Christ. . . . Dear Robert, pray for me. May the blessing of God attend you through this life, and afterwards receive you into glory."

This was his father's last blessing. He died five 
weeks after. His son preserved the letter. He writes upon it, "I have laid it amongst my mother's hair."

Pobert was not able to attend the funeral. He was too poor for that. The journey was long and expensive, and there were no railways in Caithness at that time. Besides, he did all his work with his own hands. He had neither journeyman nor apprentice. His only helper was Annie Mackay, his servant.

His sister Jane, however, went from Haddington to Tullibody, to be present with the family at the time of Mr. Dick's funeral. After her return home-for she was then married-he thus wrote to her:- "I have thought that it may perhaps lighten the distress which you suffer from the decease of our father, if I should write you a few lines, - not that a flow of words is the best source of comfort in a case such as this. Resignation to the will of God will avail much more. I hope you will see it to be your duty to bow in quiet and patient submission, looking forward with the eye of Faith to that better world, where, after a few years, you will meet your father again. Your mother is also there. Those who remain behind must toil on, and abide their time, neither murmuring nor desponding at the ways of the Supreme Disposer of all events, whether prosperous or adverse.

"These events create sad blanks. The mind for a time will be hankering after what is gone. But new affections spring up and entwine themselves round the soul, liding if not healing the wounds. Time will roll on, and then we shall be here no more. This is all that 
has been and will be. One generation cometh, and another goeth. The Framer of all things alone is subject to no change."

Robert Dick also liept up his correspondence with his old master, Aikman, at Tullibody. In the year following his father's death, Aikman told him that he was about to retire from business,- - "that he had not yet advertised the shop and bakehouse, but intended doing so. It would be a good opening for an active man, as he was now baking about 20 bolls of wheat every week, with three men and a boy."

This was doubtless intended as a hint to his correspondent to buy the business, and thus enter into a thriving trade. But Dick had no money to spare for the purpose. His business at Thurso was only paying expenses. He did not save money. What he could spare from his ordinary wants, he spent on books.

Competition was also beginning to tell upon him. Although there were only two bakers in Thurso at the time that he commenced business, there were now several. Every new baker served to diminish his trade. No increased exertion could make up for the loss. The town was small, and the people's wants were few. When the bakers amounted to six, Dick said "it was like halfa-dozen dogs worrying over a very little bone."

Dick's business was also to a considerable extent diminished by his not going to "the Kirk." When that is known of a man in a small town in Scotland, it goes very much against him. The "fear o" the folk" is very great there. Conformity is insisted on. A man must 
be what other people seem to be; or he is looked upon as a sort of reprobate.

We have been told why Dick abstained from going to church. Miss Dick, his half-sister, says that the singing caused him giddiness, and that he had some feeling in his head which prevented him sitting in church. Another says that he considered the sermons which he heard to be only "cauld kail het again;" * and that he could study the Bible and read his sermons just as well at home. Indeed, his library was full of religious works. He had seven Bibles and a Latin Testament, with various commentaries on the Scriptures. His library included a set of Bible maps, and the works of Josephus, Mosheim, Locke, Kitto, Hervey, Wardlaw, and others.

Dick had been a diligent attender of the Established Church until the Disruption in 1843. He had a wonderful memory, a large vein of humour, and even a good deal of mimicry. He could, upon occasion, give a head or two of the discourses; and for that matter, a whole sermon of several of the ministers of the town and neighbourhood, with the gesture, and accent, and peculiarities of each, to perfection. His old servant used to say, that if she wanted a sermon she had not far to go to get one. "Tae hear my maister sometimes," she would say, "you wud think you were hearing Mr. Cook of Reay or Mr. Munro of Halkirk preaching frae the tent on the Thursday o' the Sacrament."

But we have received another account, from a veritable person, as to the reasons why Dick ceased to attend

* Cold soup re-warmed. 
the kirk on Sunday. When the Disruption occurred, almost all the congregation went out with Mr. Taylor, and set up a church of their own. But Robert Dick, who cared very little for religious politics, or even for parliamentary politics, remained where he was. "I am very well satisfied," he said, "with the church of my fathers." In fact, he "stuck by the waas." * It is even said that at this time, for want of leading men in the church, it was proposed to make Robert Dick an elder. But a circumstance shortly after occurred which had the effect of sending him away altogether.

It seems that one day Dick met in the street a man named Geddie, a barber and shoemaker in Thurso. The man was loquacious and locomotive. "Ah!" said Geddie, "that was a fine sermon o' the minister's yesterday." "Yes," said Dick, "but he was perhaps a wee thocht indebted to Blair's Sermons and Hervey's Meditations." "Ay, was he?" said the barber. Away the little busybody went, and spread the report among the tattle-mongers of the place. The barber's shop is always the centre of gossip. The report about Dick and the minister soon came to be known. Of course, it reached the minister's ears.

Dick was at that time accustomed, being an early riser, to get up on fine Sunday mornings and take a walk along the sea-shore, with the magnificent prospect of Dunnet Head on one side and Holborn Head on the other, with the Orkney Islands in the distance; and a glorious

* A common saying when the members of the Established Church refused to go out with the Free Kirkers. They stuck by the walls. 
walk it must have been on an early summer morning. Dick got home by breakfast time, and then he prepared to go to church. But one day he got a sermon which made his ears tingle. It was upon the awful crime of Sabbath-breaking - upon going about on the Sabbath day, and wandering in pursuit of "science, falsely so called."

Dick could not mistake the application of the sermon. He felt that it was at him the minister was preaching. If it was not intended for him-as we have been assured -at all events he put the cap on. "Well," he said, "I'll never more be preached at. Religion is not The Kirk: neither is it in the preaching of one minister or another. I'll stay at home, and do my religious services myself."

The person who gave us the above information was one of Robert Dick's intimate friends. He says Dick was a thoroughly religious man, though he ceased to attend the Established Church. He was invariably kind, benevolent, and helpful. And perhaps he entertained deeper thoughts about religion than anybody in the parish, not even excepting the parish minister himself.

Dick himself told the same story to Mr. Peach. He said that having been shut up in the bakehouse during the greater part of the week, he thought it was for the benefit of his health that he should take an early Sunday morning's wallk; and that it was an interference with the liberty of the subject to preach at him in that way. Mr. Peach further says that he always kept a solitary service in his own house, reading the Bible, and the commentaries thereon. 
One Sunday morning Mr. Peach called in upon Dick, having walked over from Castletown for the purpose.* He found Dick reading the Bible, with Sharpe's transiation of the New Testament from the Greek of Griesbach, and comparing one with the other. "Ah!" said Dick, on seeing Mr. Peach coming in, "you never had the Shorter Catechism knocked into your head as I had during my youth." After further conversation, he said, "After all the translations of the Bible that have been made, there is none like the old translation. It has the right ring about it. And then, it is so connected with all the associations of our early home life."

The people of Thurso, however, could never understand Dick. They saw him going out at all times with his hammer and chisels, and bringing home loads of stones. What had he been doing? Had he, like Hugh Miller, been "seekin' siller in the stanes"? or had he been digging holes in the ground to bury the gold he had made by his trade ?f In these respects the peor? of Thurso were altogether at sea.

Dick went on - with his geological investigations. All his treasures were sent to Hugh Miller. He kept duplicates for himself, and by degrees collected a rich repository of fossils. He stored them in his upper room, where he also kept his best books. To help Hugh

* One of Mr. Peach's duties at that time was to travel round the coast in scarch of shipwrecks, and also to help the shipwrecked crews.

+ This statement was actually made by a Thurso person, now living in London, who left the place long ago, before Dick had achicved any local reputation, except that of an ecentric character. 
Miller, he began his researches into the boulder clay* of Caithness. "I had seen the boulder clay," says Hugh Miller, "characteristically developed in the neighbourhood of Thurso,-_but, during a rather hurried visit, had lacked time to examine it. The omission mattered the less, however, as my friend Robert Dick is resident in the locality; and there are few men who examine more carefully or more perseveringly than he, or who can enjoy with higher relish the sweets of scientific research. I wrote to him regarding Professor Forbes's decision on the boulder clay of Wick and its shells; urging him to ascertain whether the boulder clay of Thurso had not its shells also. And almost by return of post I received from him, in reply, a little packet of comminuted shells, dug out of a deposit of the boulder clay, laid open by the river Thurso, a full mile from the sea, and from eighty to a hundred feet above its level. He had detected minute fragments of shell in the clay about twelve months before; . . . but his dread of being deceived by mere surface shells, carried inland by seabirds for food, prevented him from following up the discovery." †

But now that Hugh Miller inquired about the existence of sea-shells in the boulder clay, Dick proceeded to follow up his investigations with the keenest

* Clay of the Glacial or Drift epoch, usually mixed with large stones or boulders. The boulders have been dropped in deep water from floating ice, and have settled in the clayey silt. The boulder clay is widely spread thoughont Great Britain.

+ Hugh Miller's "Rambles of a Geologist:" in Cruise of the Bctsy, P1). 311-12. Ed. 1873. 
interest. He visited every locality in Caithness where boulder clay existed. He went as far as John o' Groat's and Freswick in one direction; and to Dunbeath, at the souther'n limits of the county, in the other. He did the most of his journeys at night; sometimes walking in the dark, at other times in bright moonlight. He seems to have been intensely interested in all that he did. Everything was to him new and wonderful. His delight was often like that of a thoughtful child, in seeing further into the mysteries of a piece of fine mechanism.

"It appears to me," he said in a letter to Hugh Miller (1st September 1848), "that the best way of answering your queries, will be to relate in a plain and simple way the various truths which have dawned upon my astonished mind, during my rambles of the last few weeks.

"Few are acquainted with the peculiar features of Thurso river. Few are aware that, in many places, as it nears the sea, it has scooped out its course deep in the blue boulder clay. Near the town, on the west or left bank, a bed of this blue clay is seen within a stone's cast of the bridge. On the east you see it at Mill Bank; and on both sides, after that, an immense mass runs on, almost continuously, four miles inland, until at Todholes it becomes low, and on a level with the surrounding fields. Throughout its whole extent it almost invariably presents the same characteristic marks-pieces of blue stones, granite, gneiss, and such like.

"Not long since, the Thurso East Salmon Fishing Company ran a dyke or wall across the river; and in 


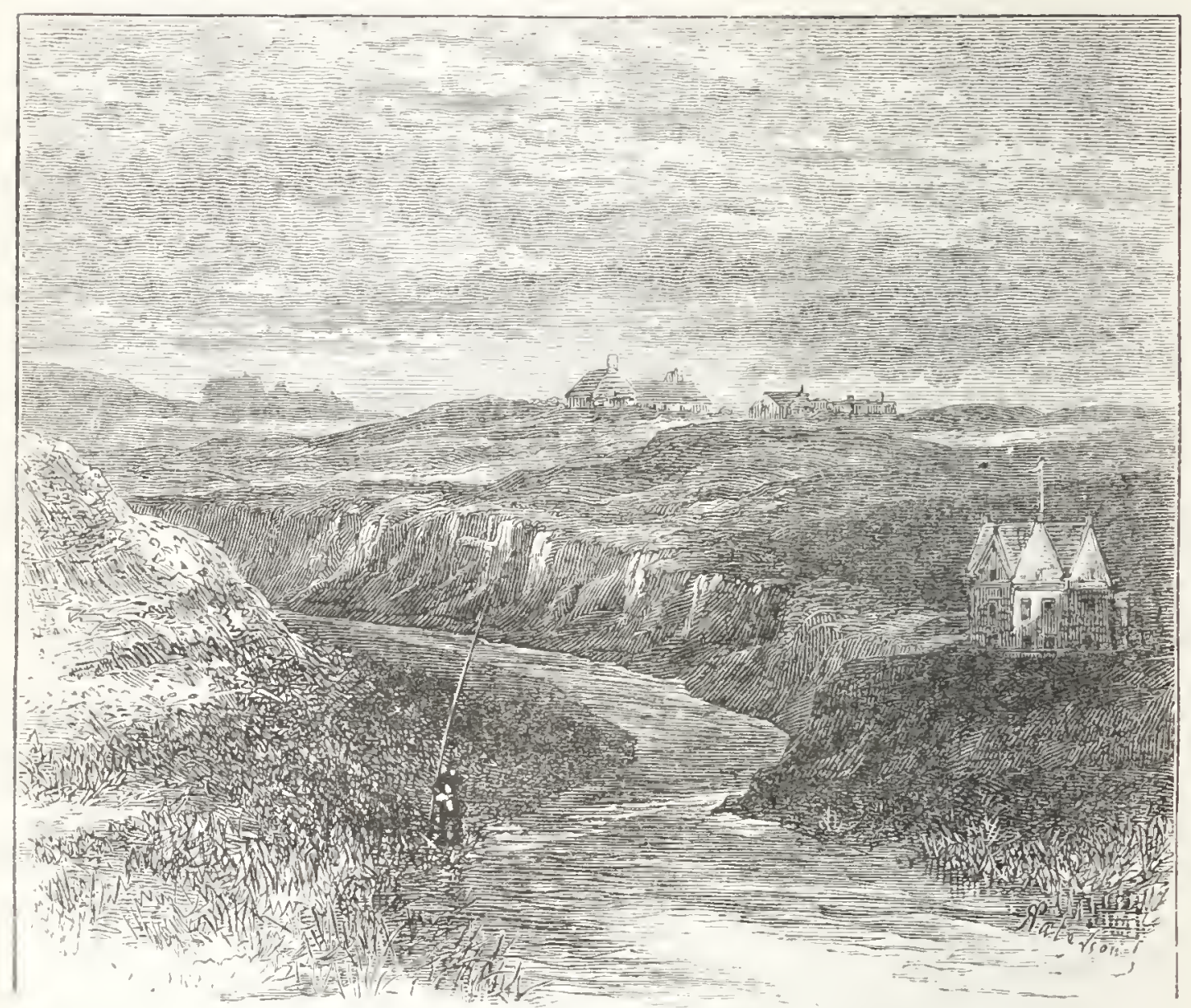

THURSO RIVER: FROM THE BRIDGE,

consequence of the openings left at the south-west end, the vaters of the river, when the rains fell and the floods rose, rushed with great impetuosity and violence on the end of a bank of blue boulder clay, undermining and bringing down large pieces of it. After one of these slippings I found the first fragments of shell. A piece of stout Cyprina was found sticking in the clay; and various shell fragments, with a considerable sprinkling of pieces like grains of oatmeal or pinheads.

"At another part of the river, a large piece of boulder clay had fallen, near Juniper Bank House; and here I detected fragments of shell, and that fragment of Dent 
alium which I sent you. The exposed portion of the boulder clay is here eighty feet in height above the river-level; and the river here may be about twelve feet above the sea-level.

"On turning to Brown's Elcments of Fossil Conchology, I find a figure of Dentalium; but in the letterpress description of it, I do not find any mention of its ever having been found in the blue boulder clav.

"On a future evening I examined the blue boulder clay at Scrabster along the bay. I detected fragments of shell here again, but not so plentiful as up the river."

In a future letter he says:- "On the river-side, right beneath the House of Geise, there is a rather high exposed section of the blue stony clay; and here again I found shell fragments. I had a good piece to walkthrough grass, heather, bracken, asphodel, and rushesbefore I met with another slope; and here also, again and again, I met with shell fragments.

"A fine section presenting itself on the eastern side of the river, I stripped and waded through the river. Here again, my now familiar acquaintances presented themselves; and here-what I had not met with before -I found a piece of chall flint. The flint was sticking in the clay.

"I was now at ease regarding the fact of the shells, but was rather puzzled with the flint. I sounded my savants, as to their acquaintance with this unlooked-fur fairy. I showed it to them, and asked them if they had seen such a thing up the comntry; when they boththe oil one and the young one-answered 'Yes.' They 
had found them when digging, and the old people told them that fire was in them, and that they were commanded in all haste to bury them again, for fear lest the cattle should get a shot!

"Another thing may be added. I know that farmers hereabout use seaweed as manure, and that shells of Fusus, Littorina, Purpura, Patella, etc., find their way up the country along with the tangles; and that cockles and periwinkles are scattered everywhere. I have even found them far inland, and away from cultivated land. The sea-mews, when hard pressed in winter, eat turnips, sea-shells, whelks, and Purpura lapillus; and flying far and near, disgorge the shells in a half-digested state. Therefore, I should not attach any inportance to marine shells on the surface of the most solitary and unfrequented moor in the county. But when I find marine shells from twenty to sixty feet deep in the boulder clay, the case is completely different."

On another evening, while searching with his pick among the boulder clay along the river side, he met with an álmost entire Turritella * amidst many other pieces of shell. He had been a shell-collector for fourteen years, but had never met with the smallest fragment of a Turritella until the previous spring, when he found a damaged fragment near Castlehill, Dunnet sands. "You may therefore," he says, "judge of my joy in finding one in the boulder clay. They are

* The living Turritellæ inluabit deepish sea water, ranging from one to three hundred fathoins. They are known as screw-shells, from the shell being elongated, many-whorled, and spirally striated. 
abundant, I know, in the British seas, but somehow, owing to the set of the currents, they are never thrown on Thurso shores."

On the following evening, he again set out to examine the blue clay, and found a fine section at Thurdistoft. A large mass of clay and stones had fallen down the bank. The stones from the blue clay differed from those of the red. He had before been at Weydale, up the country, and at the quarries on the hill of Forss, to detect glacial action on the surface of the rocks. In both cases he failed. But here, among these fallen stones, he for the first time detected signs of glacial action in four separate instances.

"I now," he says, "put off my shoes, and, despite the 'water kelpies,' took the ford and pushed on to a fine section on the east side. I again found shell fragments. My pleasure was great. I pushed on, and next found a very high section opposite the Bleachfield, on the east side. I found shell fragments here too. My pleasure was doubled and trebled. . . . I was joined by two boys, who thought it capital sport!"

Dick continued to walk early in the morning and late at night in search of his marine shells. One morning he found an entirely whole valve of Venus casina. He found at one place on the river-bank a black band or belt running diagonally in a waving manner across the boulder clay. Above it, the clay was reddish; below, it was blue. On taking part of the black belt into his hand and rubbing it, it felt like fine clay and fine sand intermixed. "Am I to infer," he said, "that the wavy 
band arose from the sea ebbing and flowing alternately over the ordinary boulder clay beneath it? And then the reddish clay, so different from the clay beneath the black belt. Just as if the abrading or grinding forces had ceased for a time, and then set to work again."

He was soon able, by his unintermitting exertions, to determine whether the sea had once washed over the county of Caithness.

"In these days of hasty revolutions," he says, "my opinions since yesterday have changed. I am now enabled to answer the question which I put to you as to whether there was a sea here before the deposition of the boulder clay.

"This morning, on clearing away the clay from my shell crumbs from Harpsdale, I found a piece of the Common Mussel and a piece of the Rock Whelk-Purpura lapillus."

There was no doubt about it. Not only had the sea covered Caithness, but ponderous ice-rafts had gone grating along the mountain valleys, grinding the rocks into clay, and dropping the boulders which they contained along the sea-bottom as they sailed along. Wherever he went Dick found shells among the boulder clayCyprina, Venus, Turritella terebra, Mactra, and several species of the genus Tellina.

One day, towards the end of September 1848, Dick went to Harpsdale, about tro miles up the Thurso river. "At Harpsdale," he says, "in the boulder clay, marine shell fragments are to be had in abundance. I lingered by this delightful seetion for about an hour." He speaks 
of the boulder clay as if it was a lover he was lingering for. He went still higher up the river that day to Dale House-crossing the river from time to time, startling the wild ducks, and inspecting the boulder clay in all its windings.

Dick found fourteen shells of the existing races which he had extracted from the boulder clay, and he had no doubt that this number might have been doubled. $\mathrm{He}$ says_-"A list of these shells is necessary, not only to mark my present success, but also to stimulate me to further efforts." He accordingly subjoined a list of the shells he had found, and sent it to Hugh Miller. "Thin shell valves," he said, "such as Tellina, have been found entire. Pieces of Cyprina are by far the most abundant. But I suspect that it will not do to say that it was owing to their superior strength-their strong construction-that they are found so very abundant. Mactra and Tellina have received slight damage; small young Crassina (a month old?) have withstood the fearful shock of mountain waves, of dashing icebergs grinding and pounding, whirling about and reeling like playthings - seas charged with mud, and stones of stupendous weight; all these have been tossing hither and thither, ebbing and flowing, and the earth reeling; and yet, a diminutive little thing like this now lying before me has been preserved! Amazing! I have met with many stones in the boulder clay grooved and scratched and rubbed in the strangest way imaginable. For the presence of these stones where they now are, I think the glacial theory is the most likely. 
"I have found gneiss, light blue kind of grauwacke, oolite, and oolite conglomerate, in the clay. I know of no rocks in situ to the west similar to these. The blue clay and dark clay is undoubtedly derived from the ordinary rocks of the county. It is found in various degrees of purity, but is in general one confused jumble, and as hard rammed as if a giant had used one of the Stacks of Duncansby as a paving hammer."

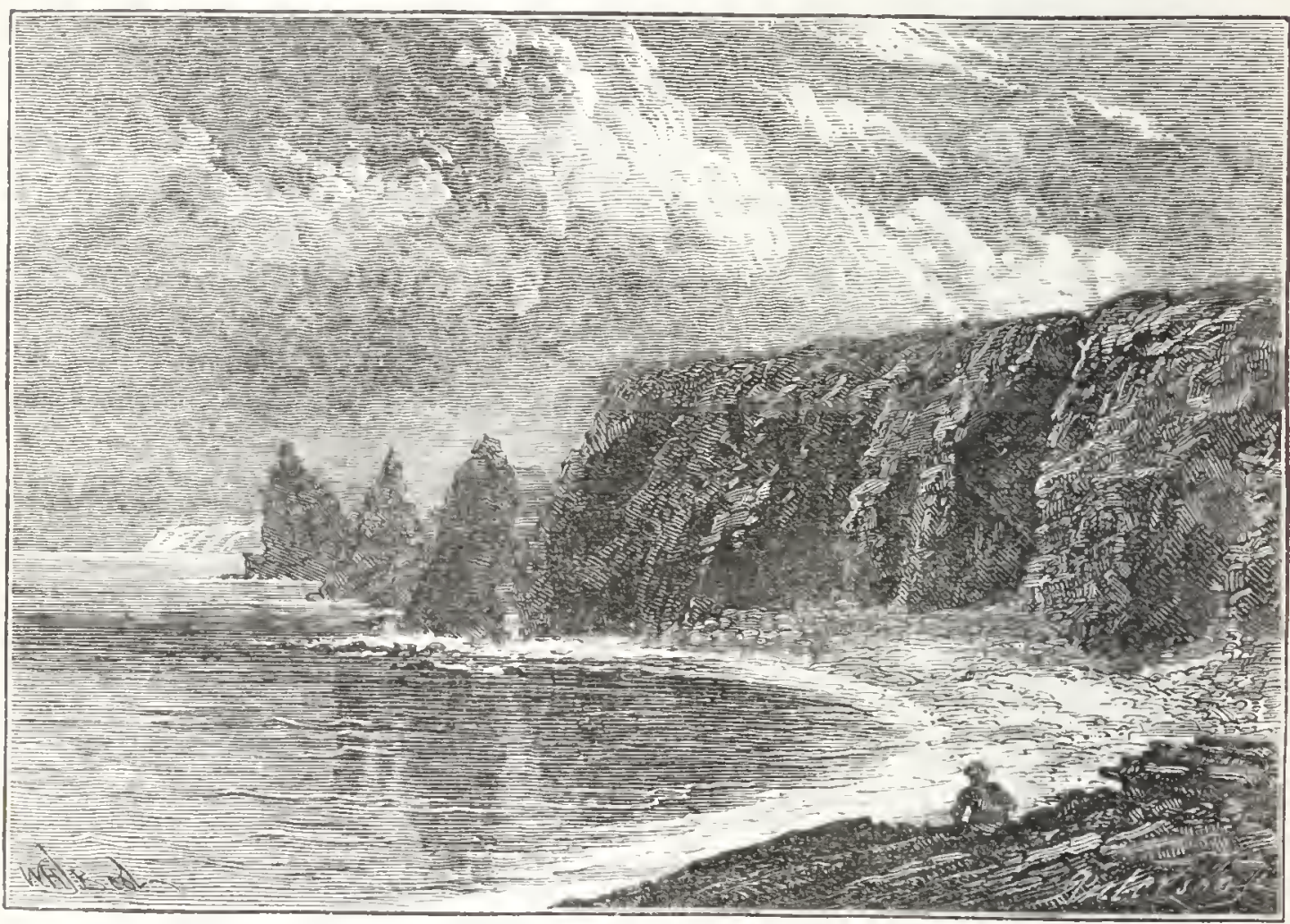




\section{CHAPTER XIII.}

DICK'S SEARCHINGS AMONGST THE BOULDER CLAY.

Dick tested the statements of other geologists, no matter how distinguished, by his own observations. Thus, he found that Sir Charles Lyell had stated, in his Elements of Geology, that very few organic remains had been found in the boulder clay, and especially in the till, throughout Scotland.

"Now," says Dick to Hugh Miller, "you see the results of my observations. Marine shells have been found in nearly all the sections of boulder clay that I have met with. But I thought it better, instead of further searching the clay near Thurso, to try another direction. I accordingly determined to travel to Freswick Bay, on the east side of the county, and trace up the burn there."

This journey from Thurso to Freswick was only one of the many instances of Dick's enthusiastic determination in the cause of science. The distance was twenty-four miles. It took him six hours of unflinching walking to reach the scene of his operations. It was October, and the weather was growing cold. Dick went across the Broad Linns extending from Barwick to 
Mey and Canisbay, a long sea-exposed road. From near Canisbay church he saw the moon overhead, and the Skerry lights shimmering in the distance at the mouth of the Pentland Firth.

The man who walks by moonlight travels among enchantments. Everything he sees is different from what it is in daylight. Roadside knolls are mountains along the horizon; the little cottages by the roadside are palatial; and the distant sea is full of glory. We tell the story of Dick's journey to Freswick in his own words. They are full of interest:-

"It is a sad drawback to my long rambles," he says, "that I am under the necessity of returning home by four o'clock in the same day. The distance to Freswick is twenty-four miles. It took me six hours to walk there, six hours to walk back, leaving about three hours for investigation on the spot,--thus making about fifteen hours in all.

"To accomplish this I started at midnight. I passed over the town's bridge at a quarter to twelve, under the favour of as lovely a moon as ever blessed an unthankful world. Though I walked alone, I walked cheerily.

"About a quarter to six in the moruing I found myself gazing up at the droll windows of the old castle of Freswick, while daylight and moonlight were yet strugghling for the mastery.

"It was too dim, too queer a light to enable me to scrutinise the boulder clay sections, so I passed over the burn and along the shore, on the top of a high ridge of sand and recent shells, blown up, I suppose, by stormy 
winds - at least 100 feet over the sea-level. I looked round and round the little bay, and thought I could discern, on the Duncansby side, a terrace about thirty or forty feet above the present sea-level. It was the first terrace I had seen. There are no terraces at Thurso. If they ever existed, the encroachments of the sea have obliterated them.

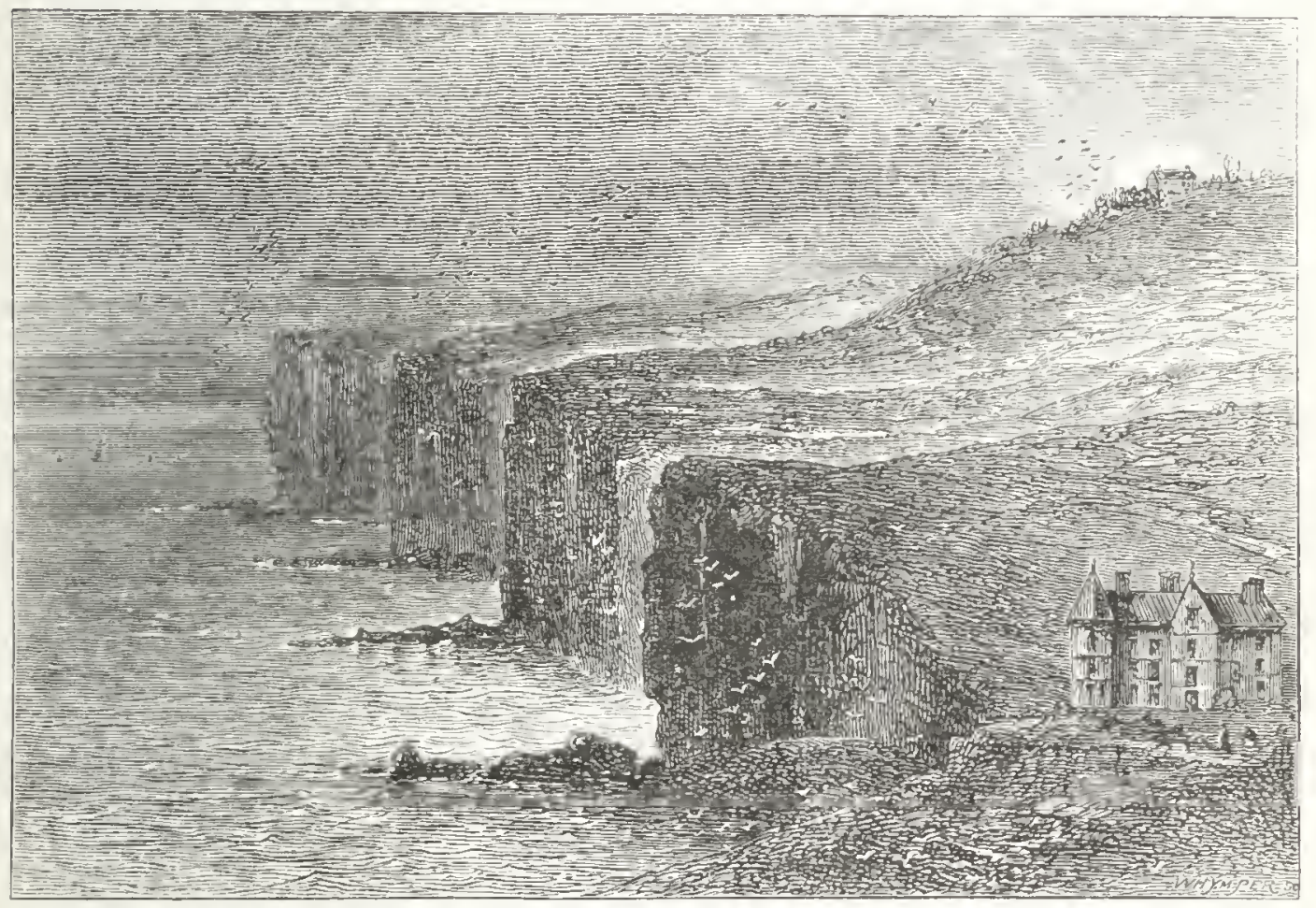

FRESWICK CASTLE AND IIEADLAND.

'The daylight was now good. It had obliterated the light of the moon. At six o'clock I turned into the burn of Freswick, close under the castle; and had not proceeded above a gunshot, when I found a low section of blue clay, thickly charged with recent marine fragments, chiefly Cyprina.

"I passed up the burn, from section to section, and extracted shells out of them all-m some instances entire 
univalves. In the first clay section I examined I found many rolled pieces of what seemed chalk; it is either chalk, or very pure petrified shell-marl. I also found at another place chalk flints!

"As I went up the burn, I found the sections of boulder clay growing higher and higher, up to thirty feet in height. I found them get fuller of stones. It had also a reddish belt-a band of sand and clay intermixed, running through it horizontally. The marine shells exceeded in numbers my fondest expectations.

"I reached the bridge carrying the public road over the burn. Though the bridge is only about fifteen minutes' walk from the sea, it took me three hours to reach it, and there I found that my time was exhausted. I had been so busily employed in extracting marine shells from the clay.

"Wishing to take the loop out of the road, I struck across the moor. I came to the burn again, and found section after section crowded with shell crumbs thicker than the spots on the leopard. Atop of the sections, a stratum of peat, and over all heather, knee deep. What a reward for my six hours' travel! What a paradise for the geologist!

"I splashed through the burn, first to one side, then to the other; till in an agony I ultimately ran away from the temptation. I found it was half-past ten o'clock! So away I went post-haste!"

Shortly after his return, Dick sent to Hugh Miller a list of the twenty-four marine shells (giving their various names) which he had already found in the 
boulder clay of Caithness. Hugh Miller had said that he "had never found in the boulder clay the slightest trace of an organism that could be held to belong to itself," and he "became somewhat sceptical regarding the very existence of boulder fossils. I must now state, however," he says, "that my scepticism has thoroughly given way; and that, slowly yielding to the force of positive evidence, I have become an assured believer in the comminuted recent shells of the boulder clay, as in the Belemnites of the Oolite and Lias, or the ganoid Ichthyolites of the Old Red Sandstone."** Hugh Miller then refers to the numerous marine shells found by Dick on the banks of the Thurso river, and in the boulder clay along the burn at Freswick.

Dick went on with his observations. On the 27 th October 1848, he thus began his letter to Hugh Miller :--

"The whole affair is settled. Scepticism may go sneak with the moles and the bats, into holes and cormers. It was no mud eruption-no temporary flood of ocean brine-that laid down the blue clay and marine shells in Freswick Burn. No! It was the ocean itself, wide and broad as poor auld Scotland, when the proudest pinnacles of Dunnet Head lay far beneath its billows.

"In my last note to you, I said that I must go and see the eastern side of Dunnet Head, chafed by the boisterous waves of the rude Pentland Firth. Monday,

* "Pambles of a Geologist," in Cruise of the Betsy,pp. 311-15. Ed.1873 
Tuesday, Wednesday, and Thursday, went by-cold, wet, and listless. But I had hopes of Friday. I rose at half-past two o'clock, worked till eight, set out at halfpast eight for Dunnet cliffs, and was home again at halfpast three in the afternoon. Try that, gentlemen-geologists; try that, if ye can!

" But what got ye?' I hear you say. 'What got ye?' Well, I will tell you every word about it; and, believe me, unless I had the opportunity of telling it to you, I would never have gone a footstep in search of auld warld shells.

"Well! on arriving at the eastern side of Dunnet cliffs, I made direct for a precipitous cliff at least 150 feet high; where, some years ago, I sat on a big boulder of sandstone, making my breakfast on cold rolls and cheese. In the present instance, I wound along the foot of these breakneck rocks, which, unless the tide had been out, I would not have been able to do,--for the tide comes close in under the cliff.

"I clambered over the fallen stones, dashed by white spray, which went clean over me like a shower-bath. Winding along, creeping my way, I could not help admiring the multitudes of Littorina rudis which besprinkled the stones. I was as much a child as ever. I filled my vest pocket-simply because they were bomie.

"I soon found that I was about to be disappointed as regards the first half of the serious work that I had come in quest of. The precipitous cliffs of red sandstone to the west of the little haven of Brough are gradually 


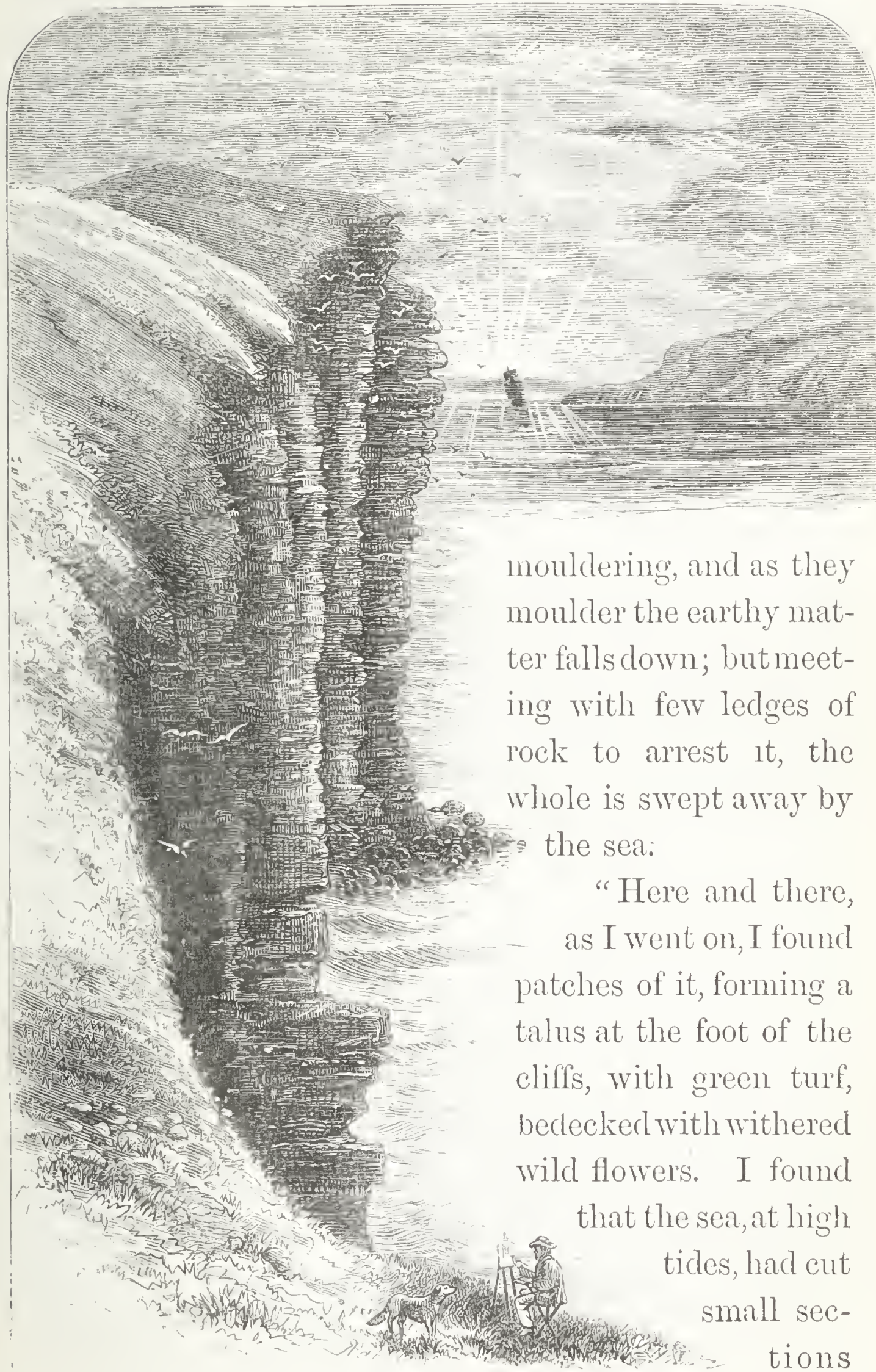

DUNNET CLIFES: EASTERN SIDE. 
out of the end of the slopes. I examined these, and found shell crumbs, but they were not the genuine thing. I found, along with the crumbs, entire shells of Helix, Pupa, Clausilia, etc. This stamped these sandslips as quite modern affairs.

"Then I went on to the cottage built beside the small, neat, landing-place on the sea-shore, at Brough Haven. The braes above here are at least eighty feet high; and a fine landslip had, not very long ago, taken place; but alas! the Government folks, anxious to have everything tidy, had driven piles of wood into the ground, and laid fresh divots* over the whole of it. Had they only known that I was coming to see the place, they would doubtless have left it bare and raw!

"Never mind! In spite of them, I found a few small landslips, and in the raw face of them I found, what surprised me, my old friend the blue boulder clay, filled with pieces of Cyprina! I gathered a handful, and passed on to a precipitous cliff of blue boulder clay, right above the cottages on the shore; and digging steps for my feet up the clay, I found Cyprina and shell crumbs of the sea. On the very top of the brae, just a little back, the Government men have built a very handsome cottage. $\uparrow$

"A very little to the west of this cottage there is a small bum. The burn has cut its way down through

\section{* Plats of grass.}

* It is at the little haven of Brough that the supplies are landed for the men at the lighthouse situated on the northern end of Dunnet Head. 


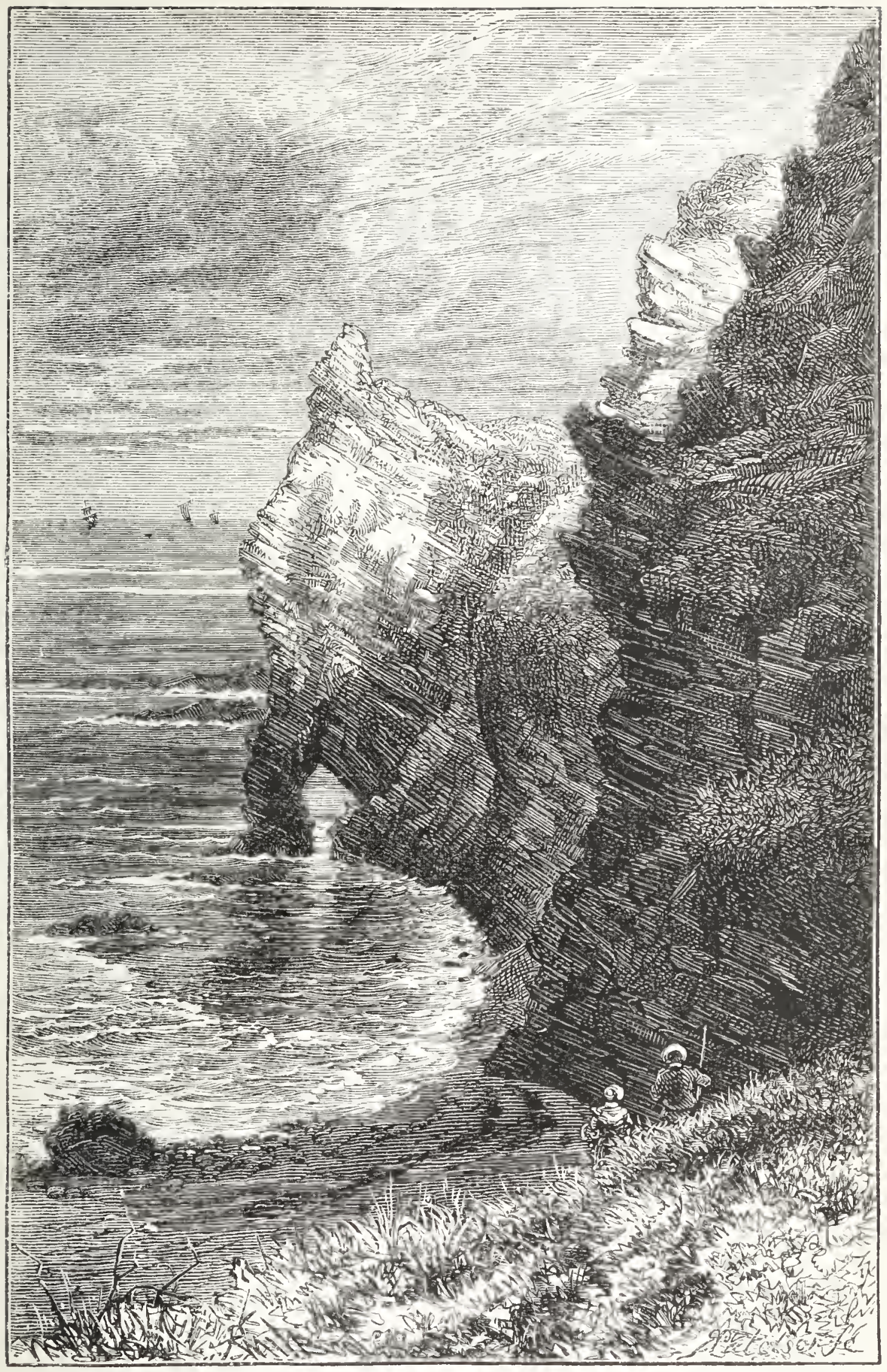

ROCKS AT BROUGH. 

the boulder clay. I went into the ravine, and stood looking round me. No sight could give me so much pleasure and surprise. I found, on walking along the little rill, that there was a tiny cascade about eight or nine feet deep, down which the mossy water leapt dashingly over a perpendicular wall of real, blue, stony, boulder clay!

"I advanced to the brink of the waterfall, and there again I stood, and looked, and wondered! Never was mortal so enchanted. Boulder clay on each side, all fretted with 'barley mill' fragments of shells, pieces of Cyprina, and blue stones, pebbly fragments, standing half out, half in, as thick as locusts. And the wide sea immeasurably far away!

"I looked down, and saw distinctly shells, comminuted shells, studding the clay at the foot of the waterfall, and the steep sides of a section beyond it, to the very edge of the precipice. I wished to jump down, but, like the cautious puddock, I reflected 'how was I to get up again?' The sides of the small chasm were as perpendicular as a wall, and nearly as hard. I tried my hammer and old knife on the hard clay beside me, and it put me to a swither.

"Yet I must get down; and at length I determined to try. Observing that the bank or section of boulder clay, nearly at the very edge of the precipice, on the east side, was a little lower than the rest, I resolved to go down there. I thought that, by digging steps for my feet, I should doubtless get up again.

"It was a venture, let me tell you. One false step, and 
down I should have gone over the precipitous wall of red sandstone-down, down, to the sea-washed rocks below. But not so fast! I am not the man to break my neck for auld-warld shells. No! So, laying firm hold of the grass, I deposited my legs downwards, quietly over each other, and then slid softly down on my hunkers! - Now!

"I walked up to the foot of the little cascade, and stood, and looked, and better looked. The boulder cliff or brae on the west side, was about fifteen or twenty feet high, and rested on polished red sandstone. It was thickly charged with stone fragments, not of red sandstone, mind you,-not one crumb; but dark, bituminous, claystone fragments, of small size, generally about the size of the heads of harrow teeth, or of old nails in cathedral doors. I found many 'barley mill' shell crumbs,-all small, not one large piece, and all of Cyprina.

"My dear friend Turritella was not there at all. I examined the pieces of stone to see if I could find grooving or scratching; but though they were all well polished, I detected no decided grooving. One or two of the largest and broadest stones had fine scratchings, but not at all so deep, or so continuous, as on the big stones I found at Thurdystoft, on the Thurso river.

"I brought away a piece of the bituminous clays, and one stone, well polished, with a hollow depression on one side. I took a few of the shell crumbs, but not all. I purposely left a fer for the CRiTICs! or the next gentleman who may venture there.

"There are moments when a real heartfelt pleasure 
amply repays us poor mortals for years of sorrow. And. such a moment was mine now. There I stood with evidences of Old World convulsions and changes environed round about me on every side. And yet there was a living cascade, merrily piping away the sunny hours at my feet, the crystal drops bedecking my claysoiled boots. Columbus had never cast anchor here. No philosopher had ever entered this paradise. It was all a new world. To me for the moment it was The World. And I triumphed in the felt conviction that a humble individual like myself had, under Providence, 'done the State some service;' for the evidence that it brings to bear on geological science is not to be gainsaid.

"Not many yards inland from this fine section of boulder clay, resting on cliffs of red sandstone on the east side of Dunnet Cliffs, high over the Pentland Firth, -not many yards inland there lies, over this clay, a black peat moss, which, judging from examinations made in it, is at least seven or eight feet thick. How old is that black moss? Hundreds, thousands of years? Yet what is that to the time that has elapsed since the icebergs went thundering over Dunnet Head? Then the sea, the wide sea, floated and stormed over all.

"Yes! there are thousands and millions of grey lichened sandstone boulders scattered over the moory top of Dunnet. There are boulders of grey granite too! $A y$, and there are boulders of gneiss and of clayslate.

"But, in the midst of these reflections, I forget that I am down in a breakneck ravine, and that it is necessary that I should contrive to get up again. Well! 
I went to the lowest part of the section, and digging steps for my feet, I clambered up until I reached the green turf; and laying hold of it with my hands I pulled myself up with all my strength. . . A And then I went. homewards, full of delight at my morning's work."

Dick was not yet satisfied. He must investigate the whole subject thoroughly. He was no featherbed philosopher. He was up in the morning early; did his work,-kneaded, worked the dough into loaves, put the whole into the oven, waited until it was baked, drew it out, and then was away on some fresh expedition.

At the beginning of November he went to Harpsdale, about eleven miles from Thurso. The weather was now cold and wet. It rained heavily during the whole day. He found in the black band, above described, a belt of fine sea sand, white and pure, dipping east. It contained sea shells and shell crumbs; clays of various colours, black, blue, green, and grey; boulders of red granite; small red granite pebbles; pieces of quartz, gneiss, greenstone, and grauwacke; chalk and chalk flints; Portskerra conglomerate; Caithness flagstones, some of them well rubbed, grooved by ice,--all in the boulder clay!

He was not yet satisfied with his first visit to Freswick. He determined to make another, though it was so late in the year. He was for some time deterred by the stormy weather. It was blowing from the north, with rain, sleet, and snow alternately. But no sooner did a pause occur than, equipped with stern resolution, he took the road. To show his determination, we quote his 
own words, which are not only full of life but of eloquence. They are taken from his letter to Hugh Miller, dated the 13th November 1848 :-

"The nights are much longer now, and of course the days are much shortened. I knew that I could not discern a piece of shell from a piece of stone before eight o'clock; and I did not wish to stand shivering there waiting for the sun.

" Up, sluggards! up!'

"At half-past two o'clock I got my parritch ready, gulped it down, and sallied forth.

"It is a cold damp morning. Black clouds are wheeling and circling along the sky. The moon is somewhere above, but I see it not. Her light is shorn. But, for the little light she sheds, I $\mathrm{m}$ thankful. It is a long, long, lonely road to Freswick; but though alone I have no fears.

" Ghaist nor bogle shalt thou fear;

Thou'rt to Heaven and Science dear!'

"I am not sure, not exactly sure, whether the deductions of scientific men are always such as to merit the approbation of Heaven. Man at best is but an erring, groping, half-blind animal. His reason is often at fault. But hark! the sleepless one gives warning. One, two, three o'clock, and now across the bridge, and now along the road,-encompassed on either side with cultivated fields, once stubbom blue boulder clay, and even yet, after hundreds of years of dibbling and dibbling, drilling and digging, it is still a rough soil. 
"On now, opposite the Cairn of Murkle, is a green mound on the left hand, where lies a large boulder of Portskerra conglomerate. It is about a hundred feet above the sea-level. There is another of the same stuff on the shore at Cleardane. At East Murkle there lies one of the largest boulder stones I have seen in Caithness. Twenty years ago it lay there amid heather and long

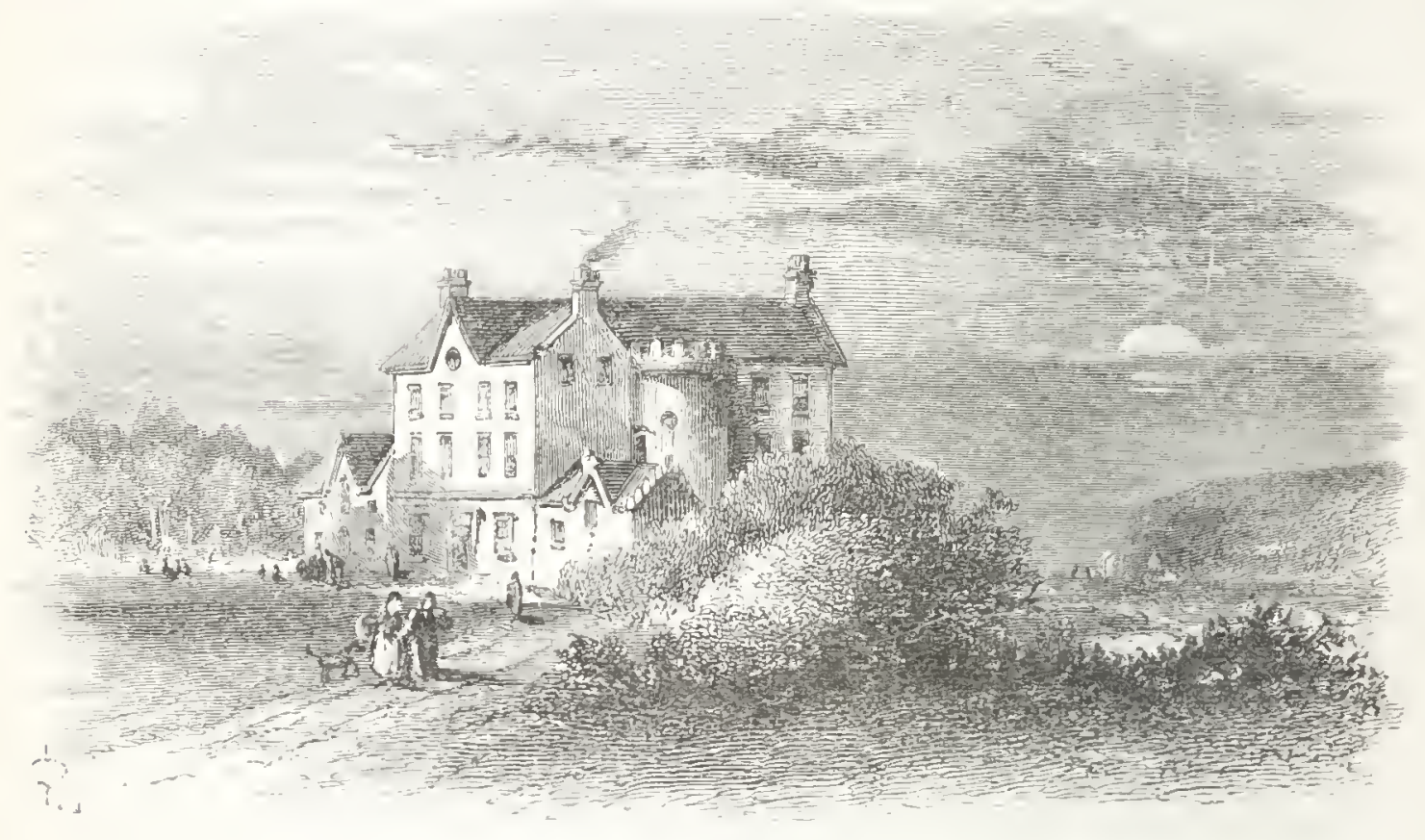

CASTLEHILI HOUSE.

grass. The field is ploughed now, and we have stubble instead of heath, but the stone is the same. It lies about 300 feet above sea-mark, and when the ice and the flood brought it there, very little of Dunnet Head was dry.

"The village of Castletown stands on the boulder clay, and there is blue boulder clay in the bottom of the bay beyond. It can be seen right off Castlehill harbour. . . At the solith-nest angle of Dimnet Sands, beside the 
House of Castlehill, the blue bituminous flagstone crops out, charged with broken fossil fish. The strata dip at low angles-nearly flat. Crossing the sands, with a group of dunes or sandhills on our right, we arrive at Dunnet, at the north-east angle of the bay. . . . The blue slate at Brough, and on to Ham, dips very suddenly. Indeed, all the way to Barrogill, one would think that the bottom of the Pentland Firth had fallen in; the strata are all on end.

"It is a dull, cold, dreary morning. Strange stories are told of wild men and wild bulls to be encountered amid the grassy links of Dunnet; but with a fearless step we go on our way in hope, remarking that surely the ocean was once farther inland than where we are treading. We are now across the links without any harm or appearance of evil. By and by we have Loch Haellan on our right, and we hear the 'quack, quack' of ducks and the startled cry of the smipe. The word is still 'On!' Up the hill, along the hill, and down the hill; and now we are fairly moving across the Moss of Mey.

"The clouds have now dispersed. Shall we look at the Aurora, or shut our eyes on Mars, on Venus, or Jupiter, or the Moon; for they all peep out and bid us good morning! Yonder are the twin lightis of the Skerries. The wind has died away; the sky is serene, and the voice of the sea murmurs plaintively along the shore. Oh! 'tis worth all the trouble, all the toil, all the fatigue, to have the opportunity of lifting up one's eyes and contemplating the beauty, the grandeur, the sublimity of such a scene as this. 
"Daylight is a sure thing. Moonlight is good, but you never feel certain where you are. There is always a hazy uncertainty about it. You may strain your eyeballs as you will, but you can never get a hold of it. But you lay hold of daylight at once. You always know where you are, even when the most imperfect glimmer breaks through the sky. Does not this tell emphatically that Man is the creature of the Day?

"How lovely looked Stroma Isle across the waters! And all the various islands far and near lying encompassed by the sea without a wave, placid as a lake. Below me iay John o' Groat's. Not without reason did De Groot choose his habitation. I admire his sagacity. Old John must have been a true poet.

"Most of the existing maps are very faulty. The one, the two, before me are eminently so. Never mind! The road strikes off to Freswick. We wander over a moss; the land rises; and then we wind along the Wart Hill.**

"The last time I walked along this road I observed what I thought looked liked boulder clay, but the moonlight prevented my observing it closely. To-day I had daylight. I found that much red sandstone débris lay thick on this side of the Wart Hill. By and by I came to a stream of water pouring in a torrent over the hill. I went off the road into the chasm made by the water,

* When going from Wick to John o' Groat's the author was driven along the side of Wart Hill. The driver said: "It used to be called the Hill of Curses. It was a Fairies' Hill. But the fairies hare all gone away now." 


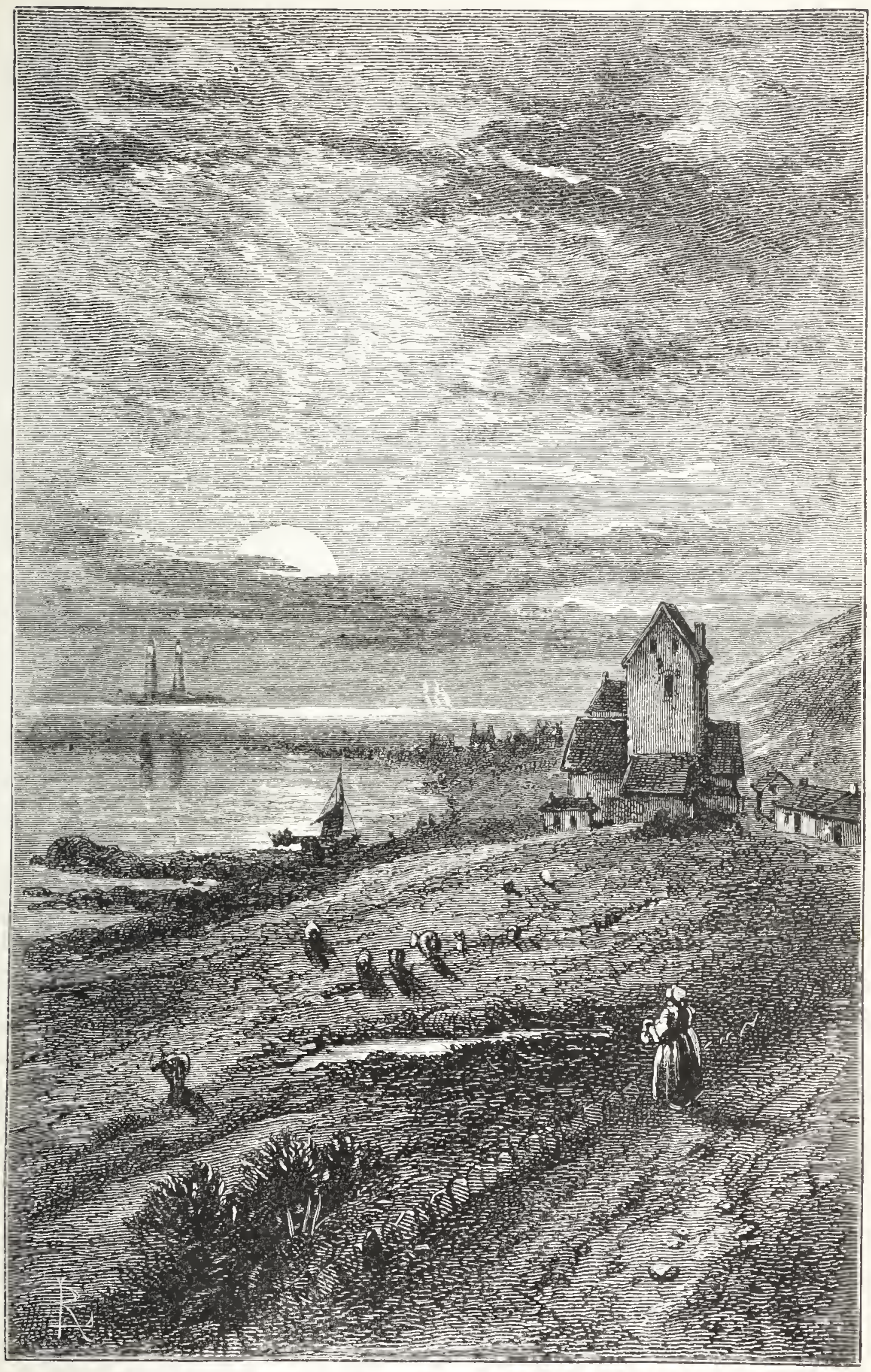

THE SKERRY LIGHTS, PENTLAND FIRTH : FROM CANISBAY. 

and found the underlying strata blood-red sandstone. Most likely it was a continuation of Duncansby Head - 'square, red, and ugly;' so Maculloch says.

"But what took me into the chasm was to examine the débris lying over the rock. I found it nine or ten feet thick. In its upper portion it seemed a mixture of blue clay and red sand, and the upper portions were very distinctly stratified. The lower portion was red, like the sandstone on which they lay. I found no shells, nor shell crumbs. The stuff contained many fragments of rubbed sandstones. There were a few pieces of quartz and granite. . . A flood of water undoubtedly brought this red débris to the south side of Wart Hill. Has Duncansby Head felt the 'plaguey knocks' of icebergs too?

"Walking on a little farther, I stood on the little bridge over the Freswick burn, with the fine sections I have come in search of, in all their glory. The burn was in flood, rushing down towards the sea. It washed the base of the section. There was no mode of getting near it, but through the water.

" 'Darest thou, Cassius, now

Leap in with me into this angry flood, And swim to yonder point?'

Na! na! Like the Duke o' Buccleuch, we can neither 'flee nor soom!' and as for sinking, like Cæsar, I find it good stiff clay at the bottom, and just hurdie deep. So in I go, and wade along the base of the section, though indeed the rush of the snow water was very cold at first; and now 'we get auld stanes in store.' 
"Well, I found a considerable variety of stones in the clay section; and they were all rubbed, or grooved, or scratched. I found pieces of flint, and rubbed pieces of chalk. I found granite, quartz, greenstone, and the

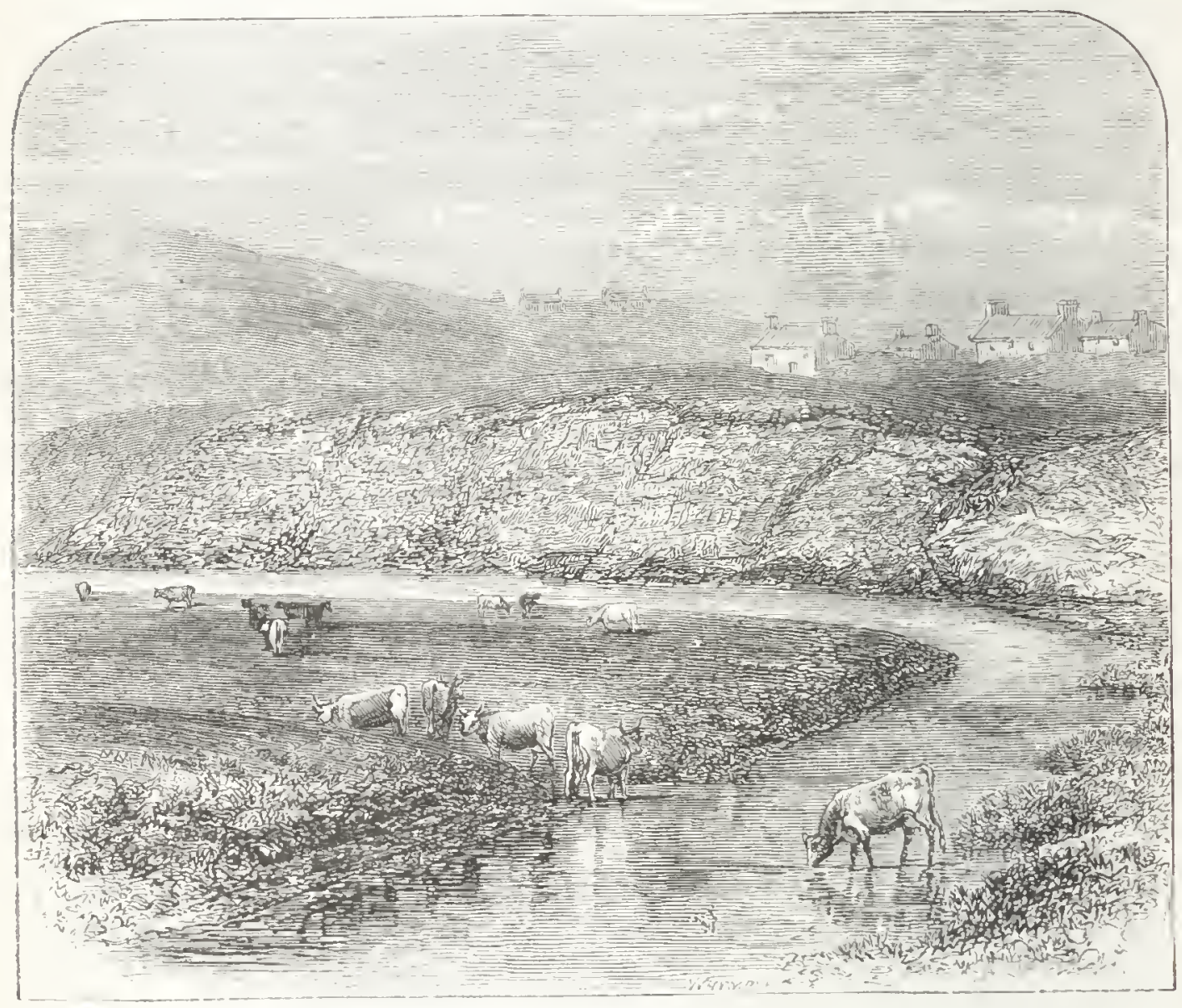

BOULDER CLAY AT FRESWICK.

ordinary clay slate of the county. I saw very large boulders. Broken shells were very abundant. I found a small fragment of broken Belemnite!* I am quite sure of it. It is a piece split down the middle, exhibiting a rertical section and two end sections. I give you a sketch of it [a drawing given]. Now, surely this is a

* An Oolitic fossil, apparently the internal bone or shell of extinct naked Cephalopods allied to the squid and cuttlefish. 
most important fact; and it is elicited and brought to light through your own request to me to make these examinations.

"Look at the map. There is a long stretch of country between Harpsdale and Freswick, and yet both contain fossils of the Oolite, chalk and flint, and a great variety of stones common to both. Nor must you suppose that a hundredth part has yet been found. No, no! What avails a hasty journey of mine? Comparatively nothing.

"I looked for my big bone of the first journey, intending to send it up to Edinburgh. But it was gone, as I half expected it to be. It has been swept into a deep pool, perhaps carried out to sea. To the best of my skill this section is stratified, and is a mixture of blue and red boulder clay, with the red predominating.

"After satisfying my curiosity at this section (from twenty to twenty-four feet in height), I left it and went to examine the strata and section at the small bridge. I found that the strata, when wet, looked blood-red; and the clay resting on it dark blue. The rest of the section seemed to be a mixture of red and blue boulder clay, containing broken shells. I have a piece of the clay and the strata in contact, for the purpose of sending to you at Edinburgh.

"Observing a small stream joining the main burn, I turned into it; and found that here too, blue boulder clay lay thicker than the stream had yet cut down to. Shells of Cyprina and Turritella were very abundant. I traced the stream up until it seemed to terminate in a shallow ditch. Recrossing, in a direct line, to the burn 
that I had left, I paused on one of the rising mounds of boulder clay-heath-clad and fern-decked-and looked around me. I endeavoured to grasp, at one glance, the extent and the amount of the formation. It was too much. The organic remains that the mass contained are immense. Arithmetic is powerful; but it fails here : it can give no idea of the tons of clay, boulders, stones, and

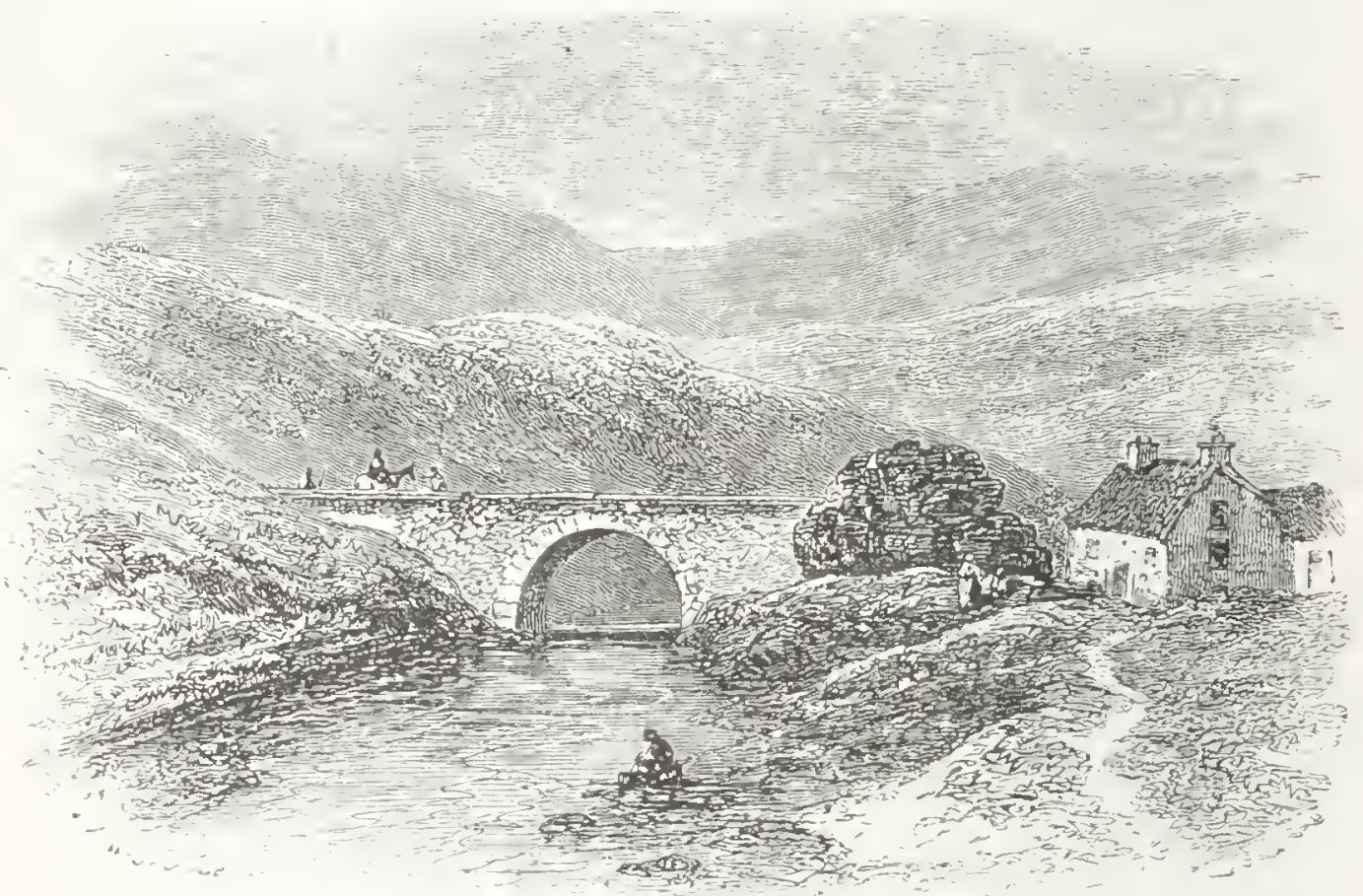

FRESIVICK BRIDGE.

shells, that have been deposited throughout the extent of country that lies between here and Dunnet Bay!"

In a future letter to Hugh Miller, Dick gives the conclusion of his joumey to Freswick. He begins :-

"The whole universe is set to music! It is harmonious. There is, in truth, no jarring, no discord! None whatever! And when man thinks that he discovers a want of harmony, the fault is in himself. It 
is he that is out of tune, and not Nature-not the Creator of the universe.

"Here is a magnificent amphitheatre of heather" One must turn round, and again round, to take in the beauty of the whole. What a marvellous extent of boulder clay formation! I crossed and recrossed the heath-adorned mounds, and I saw that the stony clay was not confined to a mere central strip in the vicinity of the Mossy Burn. It extends to a great distance on either side of it. Marking the scenery very attentively, I could come to no other conclusion, than that when the clay on which I stood was laid down, the whole of the country was occupied by a sea, wave tumbling upon wave!

"It could not have been any trivial outburst of the sea,-no rising wave from Dumnet Bay. For the clay copes the red sandstone débris, on the side of Wart Hill, - at an elevation of a hundred feet higher than the surface of the beds alongside the burn. It seems to me impossible that a rush of water, sweeping down such a declivity, could go so far out of its course, and climb a hillside. And then, when I reflected that Dumnet Head has its boulder stones,- that there is a blue stony clay in deep water in Dunnet Bay, - and that on the hillside above East Murkle, there is a granite boulder, many tons in weight, some three or four hundred feet above the sealevel,-it seemed like mockery to speak of an eruption, or outburst, or rise of the sea wave, producing these things. No! The sea then submerged the whole land, on the east and on the west, on the north and on the south. The sea then held dominion over all. Its sway was supreme. 
"It is just possible for a human being to dig into these sections of boulder clay, and think nothing about them. He is contented to find clay, stones, shells, and sea-sand, far inland. He never agitates his noddle about them. There they are! It's 'all right!' What is it to him how these things came there!

"And even when he begins to reflect-when he tries to ascertain how shells, and sand, and clay are found so far inland, how far does he get, and where does he end? After inquiring, and thinking, and guessing about these wonders,- - he finds he is no nearer the truth than when he began :

' 'Well did'st thou say, Athena's wisest son,

The most we know is, nothing can be known.'

"And yet, despite the wisdom of the Greek, Dr. Beattie holds that our Creator has permitted us to know just a very little; and the sagacious Dr. Paley affirms that what we do not know, need not disturb our belief in what we do know. Though Berkeley will have it that we cannot be sure of anything-- that there is no such thing as matter or material bodies,--yet ordinary people do not usually run their head against a post, under the idea that all that they see is an illusion.

"Here, for instance, in Caithness, are vast accumulations of what we call Clay. On examination, we find it composed of many different ingredients. We perceive it to be a body,--unique, distinct, and totally different, as a whole, from every other. Creation holds nothing similar. Slate rocks, ground down, seem its main constituent, mixed with sand. Here and there we find 
'fine braw troggin frae the banks o' Dee,' or from the plains of Streden, in the shape of chalk and flint. There, detached fragments of Morven, and the mountains of Sutherland! Yonder, broken Belemnites from the Hebrides! There, red sandstone fragments from Dunnet Head or Duncansby! Shells raked up from the bottom of the ocean! Lime encrusted with pebbles from sea caves! Rolled corallines and fresh water marl! In fact, a hundred years of scrutiny will not exhaust its wonders. These are the facts, which tell of some great catastrophe in the illusory world's history!

"What is that History? What is the History of even one of its rolled pebbles? * or of its white or blue stones? No one can tell. And yet, if we glance at them for a moment, one or two little truths can be learnt:

"First;- - those white or blue stones were once soft, and formed part of a much larger mass.

"Second; - they were detached from their parent beds, and tossed to and fro, and thus became irregularly rounded. "Third; - they then enjoyed a period of repose, during" which some of them became tinged with oxide of iron.

* Hugh Niller, referring to Diek's observations among the boulder clay, says-"Would that they eould write their own histories! The autobiography of a single boulder, with notes on the various floras which had sprung up around it, and the various classes of birds, beasts, and insects, by whieh it had been visited, would be worth nine-tenths of all the autobiographies ever published, and a moiety of the remainder to boot." Sinee the appearanee of Hugh Miller's works, Mr. Arehibald Geikie, of the Geological Survey, has, to a certain extent, earried out his views, and published a very interesting book, entitled The Story of a Boulder. London, $185 \mathrm{~s}$. 
"Fourth;- - they were once more in motion. The abrading time came. The stupendous catastrophe occurred, which drove them along to a new abode, and during this period they suffered a diminution of their surface.

"Is it necessary to say more? I state facts. Let others theorise.

"Many persons attribute the changes which have occurred on the face of the earth, to Time. But what is Time without his instruments? Rain, frost, hail, snow, ice-these are his instruments. With these he rends and brings down the mighty rocks-even the eternal hills. The Sea also is his-one of his most efficient workers.

"A mighty mass of water must once have covered the Sutherland mountains, and rolled down from them ponderous boulders, tossing them about like playthings, and throwing them far and near over Caithness. Thus, a great boulder from Morven lies at Weydale, not far from Thurso. Another lies at Slater's obelisk, on Holborn Head. In short, I cannot tell how many more there are.

"But one thing seems evident. The boulder stones owe their removal to the same causes which laid down the blue boulder clay. They lie on its surface; some of them are embedded in its uppermost tier; others are near the bottom.

"But a truce! I am still standing by the Freswick Burn, and must trace it up before I set out homewards. Well, I trace up the burn. I pass section after section, 
finding more broken shells than I can gather. There are numerous rolled white pebbles. Within a bowshot I could have filled a cart with them. And every one now in the burn was once in the boulder clay. I traced up the burn until it ended in a marsh, at the foot of a gently rising eminence. I reached the south end of Loch Scister, and then passed homewards.

"I hope to make four other journeys to different parts of the county; but I do not intend to weary you with such long palavers." 


\section{CHAPTER XIV.}

\section{THE ICEBERG PERIOD.}

Robert Dick continued, during the winter of 1848-9, to investigate the boulder clay in the neighbourhood of Thurso, and to communicate the results to his friend Hugh Miller at Edinburgh. He became more and more convinced of the áction of icebergs in grinding down the strata of the various rocks into clay and till. He found bits of Morven mountain scattered over the county, and the largest stones were the deepest grooved.

Towards the end of December 1848, Dick writes to Miller- "Perhaps you are wondering at my silence, though I have not been inattentive to the business in hand. Dogs, you know, when closest in pursuit, give little mouth. I have been as active as the very wet weather would permit, and owing to the shortness of the days I have been obliged for the most part to confine my explorations to this neighbourhood. Yesterday evening, however, I returned from the last grand boulder clay expedition of this season-perhaps, with me, the last for ever!"

This expedition was to Dunbeath, almost due south of Thurso, on the eastern coast of Caithness. Dick set out a little after twelve o'clock at midnight. He walked 
along the public road,-by Sordal, Banniskirk, Spittlehill, and Achavannich, on to Dunbeath. The distance was twenty-eight miles. He walked alone, on foot, and in the dark. It was a long, lone, dreary walk.

As the light began to dawn he saw Loch Stemster on one side of the road, and Loch Rangag on the other.

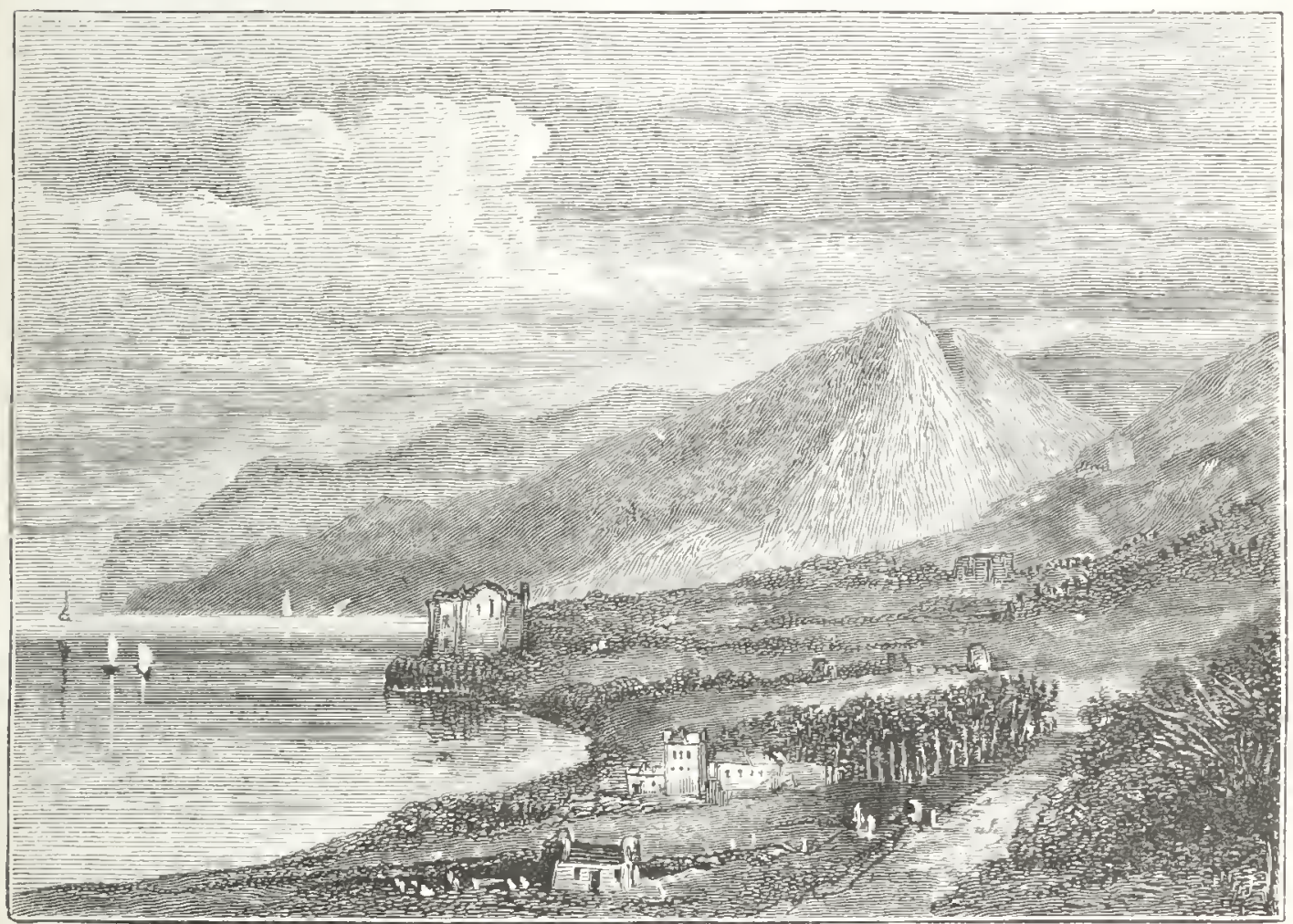

DUNBEATH : EAST COAST OF CAITHNESS.

Then he crossed the foot of Ben Cheilt, over the road made through the energy of Sir John Sinclair. This was the dividing ridge between the east and the west coasts. Out of this ridge various streams begin to flow, which run down into the North Sea. On searching about, he found that the granitic débris was not confined to the hollow places, but lay at a considerable elevation amongst the moors, if it did not lie beneath the whole 
of them. The sea must once have stood over the whole of these elevations.

Anxious to make the most of the limited time at his disposal, Dick passed up Dumbeath Water, while daylight was but a mere glimmer, picking his way among the boulders as he best could. Keeping on the right hand of the burn, he came to a magnificent cliff of dark boulder clay containing marine shells. "I stood," he says, "in amazement at the scene, in the dim light of the morning. I would willingly have sat down on a stone and waited the coming of the day. But the whole breadth of the county lay before me, with mires and moors unutterable. To linger here might be fatal, should darkness overtake me. I might never be able to struggle out of these horrible moors. So 'On, on' was the watchword!

"But observing many white specks of, I could not tell distinctly what,- 'I darklins grapit;' and you will hear with interest, that the first object I got between my finger and thumb was a specimen of Turritella terebra! That shell is now on its way to you by post.

"I passed on, and found that there was much of the dark clay in this spot, and of great height. Stopping at another section I picked out another specimen of Turritella, a broken hinge of Lutraria, broken Mactra, Cyprina, and other shells. By this time it was nine o'clock; and as the daylight was good I saw almost every variety of granite-red sandstone, and abundance. of old red conglomerate.

"To wait and stoop, and minutely scrutinize, was out of the question. I moved on from section to section, 
admiring as I passed. I saw cliffs of pulverised granite resting on blue boulder clay; and blue boulder clay resting on pulverised red granite. The latter was very fine, and far more abundant than the blue. Section after section stood up sheer as a wall, and the red was blazing like a harvest moon.

"In two places I saw traces of stratification. I saw blue boulder clay containing marine shells a long way up the burn.... The bare boulders are very large. The granite débris is amazingly abundant. But why should I linger thus? Away to the source of the burn. Away to the moors!

"And in the name of all that is truly miserable, nothing can be conceived more dreary than those widestretching heaths in a cold mid-winter day. The gay cotton-grass flaunts no more, with its white pendent heads rustling in the breeze. The heather bells are dead. Nor bird nor insect is there. Even the hardy club moss has acquired a sallow hue; and save the wimple of some merry tinkling rill, all is lonely and melancholy.

"Away through the moors; and again through the moors! And such moors! Hop, step, and jump is holiday diversion compared to passing over these rude hummocks. One's frame trembles with the concussion. Try it on the hummocks! Try to pick your way by wading through the pools of water. Try and get round and between them. It is all the same. You sigh in hopeless agony. You get bemired to the knees, and long for a clear pool of water where you may have a satisfactory washing. 
"Loch More! who has not heard of the loch? Yonder it is, tossing lightly its cold blue waves. I see the lofty two-arched bridge crossing the river that flows out of it to join the Thurso on its way to the sea. Acharynie lies yonder. An auld carle is moving over the hill, keeping fast by the track road, and that road shall be mine too by and by.

"But after leaving the moor, and seeing a farm-house near at hand, I stepped aside to ask the nearest way. I reached the barn-door, and found an old reverend-looking man threshing bere.

"'Please,' said I, 'how far is it to Dalemore, and which is the best road?' 'Eh? Are ye gaun to Dale-more?' 'Yes.' 'And where cam ye frae?' 'Dunbeath.' 'Did ye come frae Dunbeath the day? 'Yes.' 'An' where are ye gaun tae?' 'Thurso.' 'Are ye gam to Thurso?' 'Yes.' 'And did ye wide the river?' 'Yes.' 'An' are ye gaun to wide it again?' 'Please tell me the best road to Dalemore.' 'Hae ye snuff?' 'No, I am sorry I have no snuff.' 'Oo ay! Haud doon the strath; doon by the river; strecht doon!' 'How many miles is it to Dalemore?' 'Four miles; ay, just four miles.' "

"Candid man! Oh, the want of sneeshin! No magic like a snuff-box to get to the heart of a Hieland$\operatorname{man!}$

"I think it is old Daniel Defoe who lays it down as a truth, that a man should never act contrary to his judgment and his conviction as to what is right, more especially if he has a mysterious misgiving about the 
matter in hand, for which he cannot account. And yet how often men do so, and how often they find reason to repent!

"The ill thief blaw yon carle south, An' never snuff be near his drouth; He tauld mysel' by word o' mouth, The strath was better;

I lippened to the loon in trouth, And was his debtor.

"I went down the strath by the river side-'strecht doon,'-in direct opposition to my better judgment. Philosophically musing in mud and mire, I could see that Loch More was once much larger than it is now. The river is fast filling it up with siliceous sand, clay, and peat mud. I walked over a very large piece of alluvium, wrested slowly and in detail from the bed of Loch More by the stream flowing into it. Loch More * will one day become Loch Little, and finally disappear. Such are the changes taking place on the earth under our very eyes!

"I had nearly rounded the loch, and was congratulating myself on my expeditious dispatch, when all at once I was startled by a deep broad stream emptying itself into the loch! To cross it was impossible; to turn back was maddening. Oh, the reverend-looking man threshing bere! 'Oh, the confounded scoundrel!' said I loud out. But 'forgive us our debts,' I added, and let us begin anew.

"I turned back, and had to walk and jump over

* More or MTohr, Gaelic for big or large. 
moor, mire, and pool. I went in a retrograde line up nearly to the carle's house before I found a spot shallow enough to wade through, which I did.

"With many musings on the desperate deceit of the human heart, I had some very hard work in getting through a very bad moor, utterly unable to account for the trick played upon me. At last I thought I had hit it. 'He took me,' said I, 'for an exciseman!'

"With thankfulness I struck the Thurso river a little above Acharynie. It is accounted fifteen miles from Acharynie to Thurso, and, having a level road, the journey might be said to be at an end.

"The granitic débris lies in great thickness over all the country there. I saw deep sections of it by the river-side far above Acharynie. The chasm ur valley in which the river winds is of considerable deptl: exhibiting many fine sections of granitic débris.

"A little past the old church I saw two fine sections of blue boulder clay. But they were not for my examination at present. The old carle had done for me. My time was gone. I had settled in my mind a visit both to Dallmore and Cattack. But I must push on. I was obliged to rest content with seeing them afar off.

"In this, my last grand boukder clay expedition of the year, I have accomplished a feat in pursuit of rotten shells, which perhaps not many men would have willingly undertaken. I have walked more than fifty miles without once sitting down. Then next morning at five o'clock, I rose to my daily work as if nothing unusual had happened. 
"The historian says of the Roman Emperor Hadrian that, "careless of the difference of seasons and of climates, he marched on foot and bareheaded over the snows of Caledonia and the sultry plains of Upper Egypt.' Pshaw! There are thousands of Scotsmen, even in these effeminate times, that would scorn to yield a hairsbreadth to the Roman Hadrian, even in the best days that he ever saw."

Dick enclosed in his letter to Hugh Miller, describing the above expedition, an extinct shell, Fusus Heywoodii, a fossil of the English Crag; "though," he said, "Captain Brown does not figure it in his quarto volume of Recent Shells." In his next letter Dick says - "I am half in doubt whether you would not consider me crazed in my last. Stultus ego. But these journeys are quite exhilarating. To those who live by their labour, 'every inch a man' is a great deal. I am sorry to hear that you are so weakly. You sit too much at your desk."

Dick goes on communicating his thoughts to Hugh Miller about the formation of Caithness. "No deluge of water," he said, "could, in my opinion, have ground down granite rocks to the consistency of clay. Nothing so likely to produce what we now see around us as a shallow sea, alternately freezing and thawing, and hampered with icebergs. What is to become of the Mosaic deluge? My 'supernatural' is truth. ... I had already fallen in with the notion of a westerly current across Caithness. I have seen much to confirm that view. Reay Bay, Strath Halladale, and Shebster Valley 
were, in my opinion, grand inlets to the sea-long, long after the hills of Caithness were up and out of it."

Although Dick had been misled by the reverendlooking carle, and prevented seeing the sections of boulder clay at Acharynie, Dallmore, and Cattack, on his return from Dunbeath, he nevertheless resolved to return for the purpose of inspecting them. He set out on the 18th January. The weather was severe. Snow covered the ground, but it was hard under foot. "It is a glorious thing," he said, "to feel the keen bracing January winds blowing against your cheek, while the leart beats undaunted in your bosom."

He set out from Thurso about three o'clock in the morning, and arrived at Acharynie a little after eight, just as the day was breaking, bright and radiant. In the course of his search he found the usual sea-shells in the boulder clay of Acharynie-broken fragments of Turritella terebra, Cyprina, and the like. As he passed down the river Thurso, he came to an interesting object-

"As I went down the river-side," he says, "I found that the granite had at some period forced its way through the clay slate; and the slate seems hardened and turned in different directions. The river now assumes a different appearance; it goes tumbling and plunging along. The bottom was rocky. By and by I came to a place where a small wooden bridge is thrown across, presenting quite all enticing scene for lovers of the picturesque. The place is also well worthy of the attention of the geologist. The granite is here piled in rude shapeless masses; and along the side of one mass, 
the footpath leading to the bridge has been cut. The wandering geologist approaches, and just as he is about to step on to the bridge, to look down upon the raging torrent below, his attention is arrested by the interesting phenomenon of the primary or igneous rock lying in contact with the slate or secondary rock. The molten matter seems to have forced its way up through the clay slate, bending it as easily as the potter does his clay; and the heat has fused it into mica slate.

"Not only are the strata in contact with the granite altered to gneiss and mica slate, but about the centre of the mass a piece of black mica is seen, with a vein of different-coloured granite leading to and beside it,suggesting the idea that this black mica had at one period been a piece of ordinary schist, which had got entangled in the molten matter as it rose, and thus assumed the appearance which it now exhibits. I broke a piece right out of it, and will find an opportunity of sending it to you. I also took a piece of red granite for you, and a piece of gneiss. The gneiss is most interesting in situ: it is bent into a beautiful curve. Such and such is the fact, if the metamorphic theory be the correct one; indeed, the metamorphic men could hardly find a better argument than in this case.

"After the river passes this bridge its channel becomes rugged in the extreme. Then you come to Dirlot Castle -a picturesque ruin on a granitic rock, about thirty feet over the river's channel-a very romantic spot!"**

* Some of the scenes through which the river Thurso passes, especially in the upper parts of the parish of Halkirk, are full of romantic 


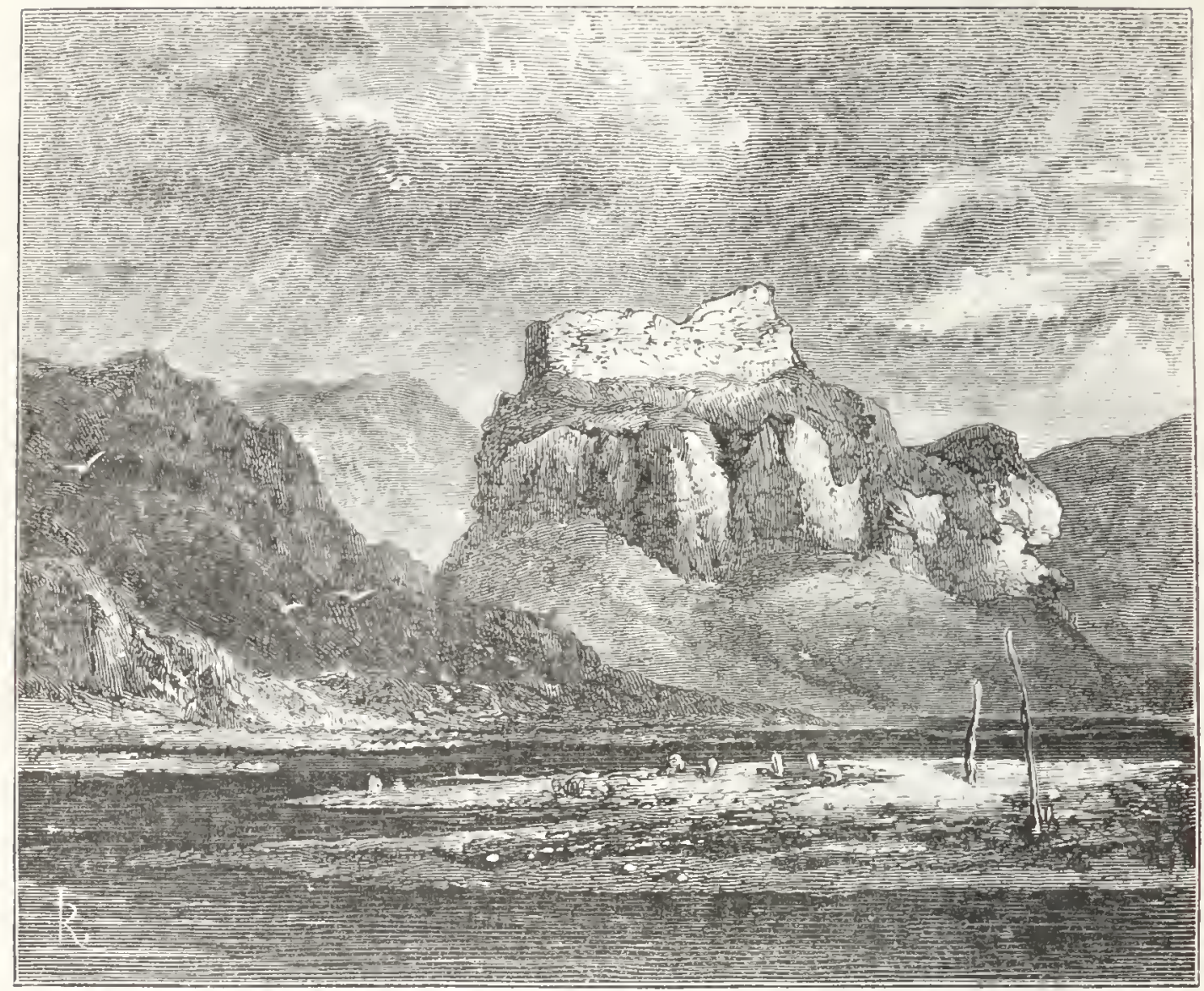

RUINS OF DIRLOT CASTLE.

On this occasion Dick was forced to return home before he could examine the boulder clay at Dallmore and Cattack. A fortnight later he paid his intended visit. He explored the boulder clay-found marine

beauty. The view near Dirlot is particularly striking. Here the banks on each side are steep, and richly elothed with brushwood. Dirlot Castle is the oldest in the county. It stands in ruins on the summit of a preeipitous roek. It is said at one time to have been surrounded by the river, and aecessible only by a drawbridge. At the end of the fifteenth century, it was inhabited by a chief of the name of Sutherland; and local traditions state that it was often the scene of revelry and staughter. The castle afterwards beeame the possession of the Mackays. The Gumns and the Mackays were the great elans of the north of Sutherland and south of Caithness, and fought many ferocious battles $1 n$ the district. The Gumns were of Scandmavian orıin. 
shells; chalk flints; a piece of petrified greenish marl, with a small organism on its surface. He was occupied a long day in exploring the clay, but the result was comparatively nil.

"As I was going along by the side of the stream," said he, "a large boulder of oolitic conglomerate presented itself to my delighted vision. It had evidently been washed out of the clay by the slow undermining of a mossy rill, and there it lay, all unnoticed, telling its own pathetic tale to the gnats and midges which were dancing over it.

"I had uniformly met with pieces of oolitic strata in these cliffs of boulder clay, but this piece far exceeded all that I had previously encountered. It was like a large snowball, such as boys roll together in winter. It contained a great abundance of broken shells, and broken Belemnites not a few. I hammered at it a long time until fairly wearied. Then I left it, and in a section of boulder clay beside it I found broken shells of Cyprina, and one stout Turritella terebra."

He next went across the county to Strathbeg Water. "There are conical mounds," he says, "of granitic débris all along its south side. I ascended to the top of one of them, and looked along the Strath. As far as I could see, the mounds stretched almost continuously, like the ruins of some ancient Roman dyke; and they spoke emphatically of contending seas in times long gone by.

"I waded Strathbeg Water knee-deep, thinking of poor Mungo Park fording the tributaries of the Niger in the deserts of Africa. Ah! true. But then it was 
not to find decayed shells. No! But to please Sir Joseph Banks and the African Association. And then there were the golden-roofed houses of Timbuctoo!"

Dick had many more excursions to make before he could satisfy himself as to the extensive existence of the boulder clay throughout Caithness. For instance, in March 1849, he made a long ramble between Dunnet Bay on the one side of the county and Sinclair Bay on the other. The weather at that time was horrible-.. frost, snow, snow-drift, wind, rain, and sleet. Then his journey of forty miles had for the most part to be made through lonely moors and marshes, where the wanderer sank up to his knees at almost every step. He was wet to the skin all the way. And all to find the relative extent of the boulder clay!

$\mathrm{He}$ rose at midnight and did his morning's work. The bread was all ready for sale when he set out at four o'clock. He first made for Castleton, tramped across the sands at Dunnet, and steered south-east for Sinclair Bay, with rain, snow, or sleet accompanying him the whole way. He passed many boulders of the old red conglomerate. He passed along the verge of four lakes, the moss and heather beside them all saturated with water-slush, slush, slush! At length his ears were greeted by the sounds of old ocean thundering along the beach of Sinclair Bay, with Noss Head in the distance.

Every step of the road was full of observation. Dick noted the evidences of the sea having at one time been dashing its waves far inland. He saw the remains 
of an old sea-beach far up the shore. It took him ten minutes to walk from there to high-water mark on the present sea-beach. He concluded that the sea once covered all the land between Dumnet Bay and Sinclair Bay, and that it was gradually retiring from the land.

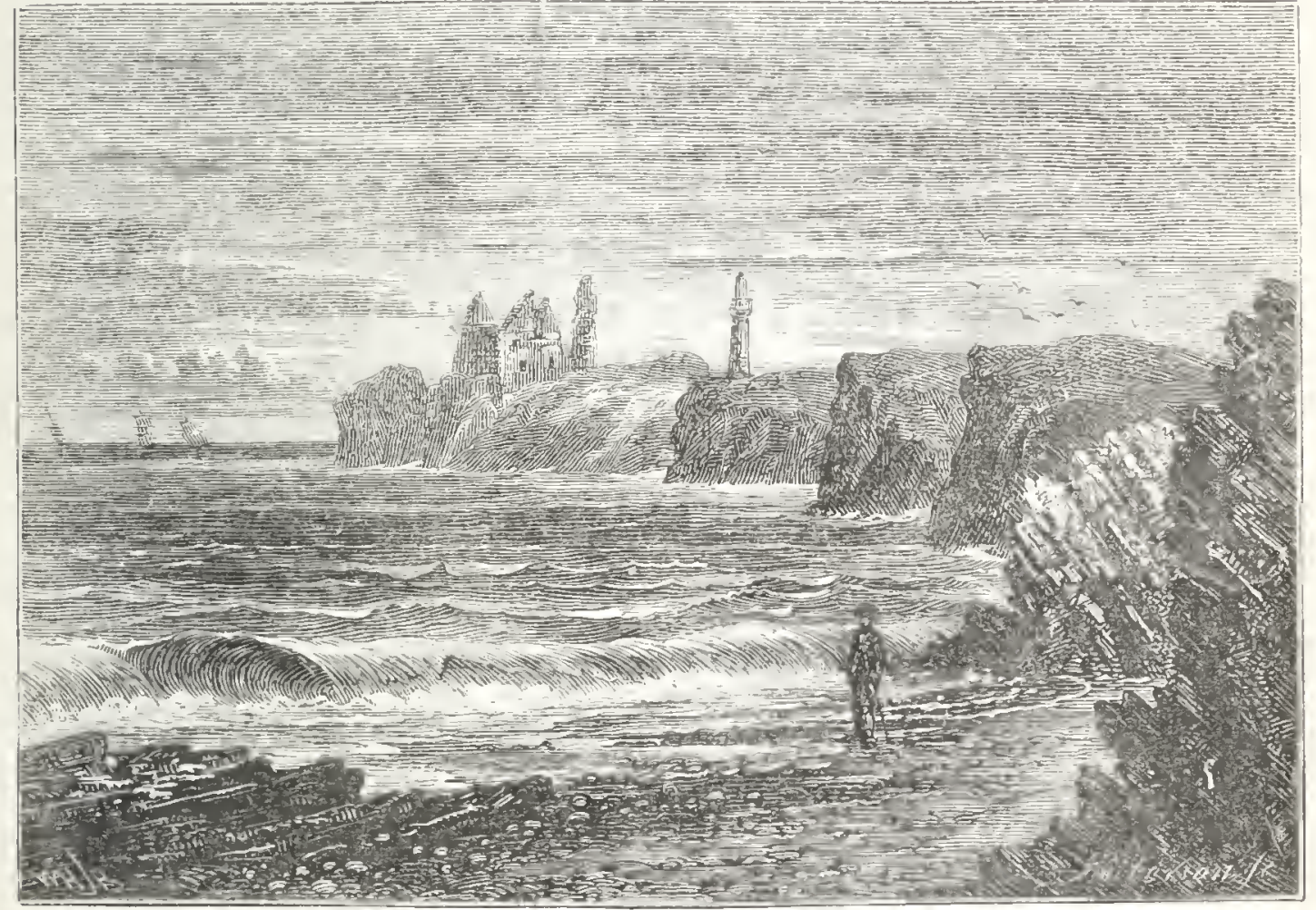

SINCLAIR BAY AND NOSS IEAD.

He set out on lis homeward joumey by Wester Loch. The shores of the loch were composed of marsh, peat, sour grass, and mire. As he approached, he startled the sea-birds which frequented it. There were sea-mews, sea-ducks, wild geese, and wild swans. He counted thirty-six ducks rise in rapid succession. At the head of the loch he found a travelled stone-a mass of grey granite several tons in weight-moored just within the dry land. Two large boulders of the same materiai lay on the opposite side of the water. 
On he went, observing many high braes of undoubted boulder clay, though covered with grass and heath. He observed also sections of granitic débris similar in every respect to those he had seen at Dirlot and Dallmore. And then he came upon a mass of blue boulder clay filled with marine shells-Cyprina, Crassina, and Turritella terebra. "At this moment," he says, "I cannot tell how I felt. Here, at last, was abundant reward for my day's journey.

"On I went, hoping that my luck was in the ascendant. But no. The soil along the bottom of the Bower valley is wholly sandy alluvium. I was 500 years too late! The river has done for this locality what Thurso river is busily doing for the boulder clay, namely, tumbling and rolling it about from side to side, sweeping it away, and laying down alluvium in its place, till at length, imprisoned in its own toils, it rolls away, a sleepy, despised, obscure thing.

"On and on. Floods have been here, and see! here on the river banks is something new-shells of the Alosmodon margaritiferus lying open, and the dead animal in them. And see! pieces of broken Cyprina from the boulder clay lying cheek-by-jowl. Do you ask me how I knew them to be from the boulder clay? Simply by the family likeness. There is no mistaking one's old friends.

"On and on, through marsh and mire, ankle-deep, and deeper. On to the confluence of the water of Wester. Boulder clay and shell fragments are found all the way. I traced up the river of Bower until it was 
only a stride across. Shortly after I entered the Bowermadden road from Castletown to Wick. I went on to Castletown, and saw that there was a continuing hollow by Duran Loch on to the very south corner of Dunnet Bay.

"Raise the sea a hundred feet at Dunnet Bay and a hundred feet at Sinclair Bay, and, in my opinion, their waters would unite. The evidence of marine shells is also nearly continuous from Dunbeath to Thurso. The evidence of marine shells is also continuous from Freswick up as far as Brabster mire. I have no doubt that during the boulder clay epoch the whole of Caithness was under the sea."

Dick continues to send Hugh Miller various fossils found during his journeys. On the $22 \mathrm{~d}$ of March he sends a fish jaw (of the Asterolepis), with an excellent drawing of it, carefully done. The drawing afterwards appeared in Hugh Miller's Footprints of the Creator. Three months later Dick tells him that he has found a hyoid bone of the Diplopterus, "another victory over the unknown." He made numerous excursions for the purpose of enabling Miller to illustrate the Pleistocene formation. He went to Harpsdale in the south, to Freswick in the east (starting at midnight), and to Ben Shurery in the west. The Ben consists of granite and granitic gneiss, but near the top of the hill he found two boulder's of red conglomerate, of vast size.

"No Oolitic or Liassic strata, in my opinion, exist in Caithness, so you must account for the great abundance of fragmentary strangers in some other manner. How 
mysterious the whole becomes! How much are we still in the dark! However, thank heaven, the FIsH were, before the mountains of Shurery, Braalnabin, or Dorery had any existence! Were I to tell some people this, they would not believe me."

"The view from the mountain top," he adds, "is very grand. And though the wind blew rather cold for one bathed in sweat, I tried to look abroad. To the north the Orkneys and all the intervening lands lay tabled before me. Turning round to the south-east, Morven towered aloft, wreathed in snow. From the little loch underneath me, stretched a low wide country covered with brown heather and dotted with lochs."

Another of Dick's rambles was an extraordinary one. He walked from Thurso to Strath Halladale in Sutherlandshire, then up the dale and round to Thurso by the Dorery Hills, a night's walk of more than sixty miles. Here is his own account:-

"I left Thurso," he says, "at eight o'clock in the evening; went on to Reay; from Reay to Portskerra; then ten miles up the deep Strath Halladale; then to Rumsdale; then turned down to Loch Shurery; then over the top of Dorery mountain, down on Braalnabin; rounded the loch of Calder, and along the public road to Thurso again, - a delightful amount of labour certainly.

"I travelled all night alone, simply to test the fact of the sea finding its way over Caithness, and covering the lands towards the sea.

"At midnight, twenty minutes to one, I was standing 


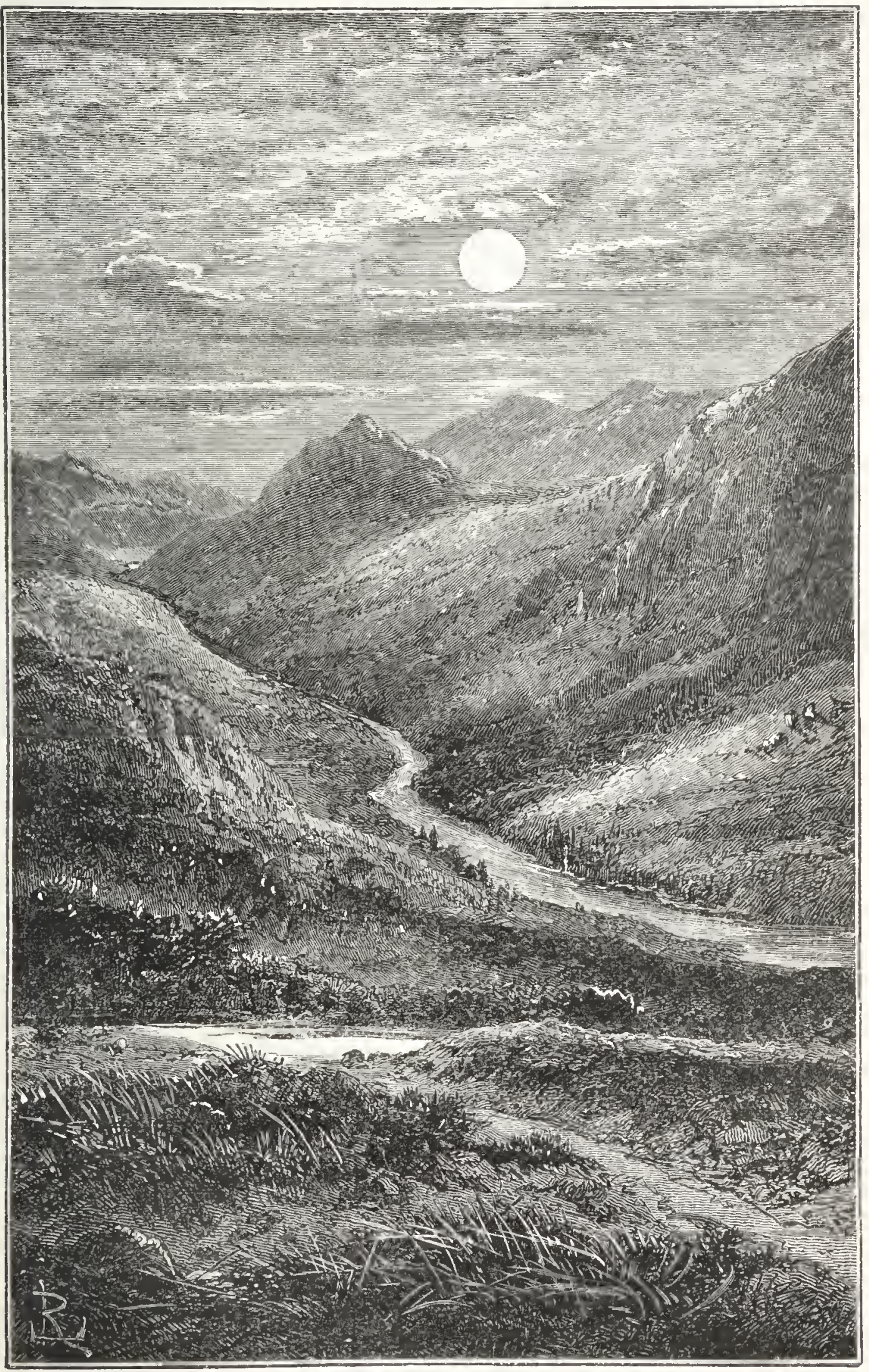

STRATH HALLADALE. 

by the finger-post, at the lower end of Strath Halladale, reading the directions to weary travellers; but the ungrateful Highlanders had so pelted it with stones, that, save the word I'rantlebeg, the finger-post gave me no information whatever.

"It was a lovely night. The scene was most impressive. The full moon shone clear on all around me. Not a zephyr was astir. The drowsy sheep slumbered on the hills. The sea scarcely broke along the shore. The river ran clear and sparkling, but without a murmur. The silence that enveloped the granite peaks was sublime and solemn. My heart beat happily. 'My vera een' were enriched; for all my musings, all my expectations, were more than realised.

"There is a good hard road up the strath, and it winds along the river side. The granitic débris lies thick on the hill-sides, and boulders by the million. Above all, the bottom of the valley lies delightfully low. The bed of the river, where it enters the sea, is scarcely, if at all, above high-water level. For many miles up the strath the water scarcely runs. Now, there is a deep pool, hemmed in with rolled pebbles, over which the stream struggles. It runs on a little, and then there is a pool again.

"A considerable number of black cottages still grace the sides of this valley, of a better cast than the common run of cottages in Caithness. But this strath, by the way, is in Sutherland.

"About nine miles up, I found the full reward of my labours in the fact that there was no impediment, 
but indeed every facility for the sea entering the country and drowning Caithness, were there only some upheaving agency to hitch it up some 100 feet or so. It was simply to test this, that had brought me thus far. The road winds up among the hills-hollow, all hollow:

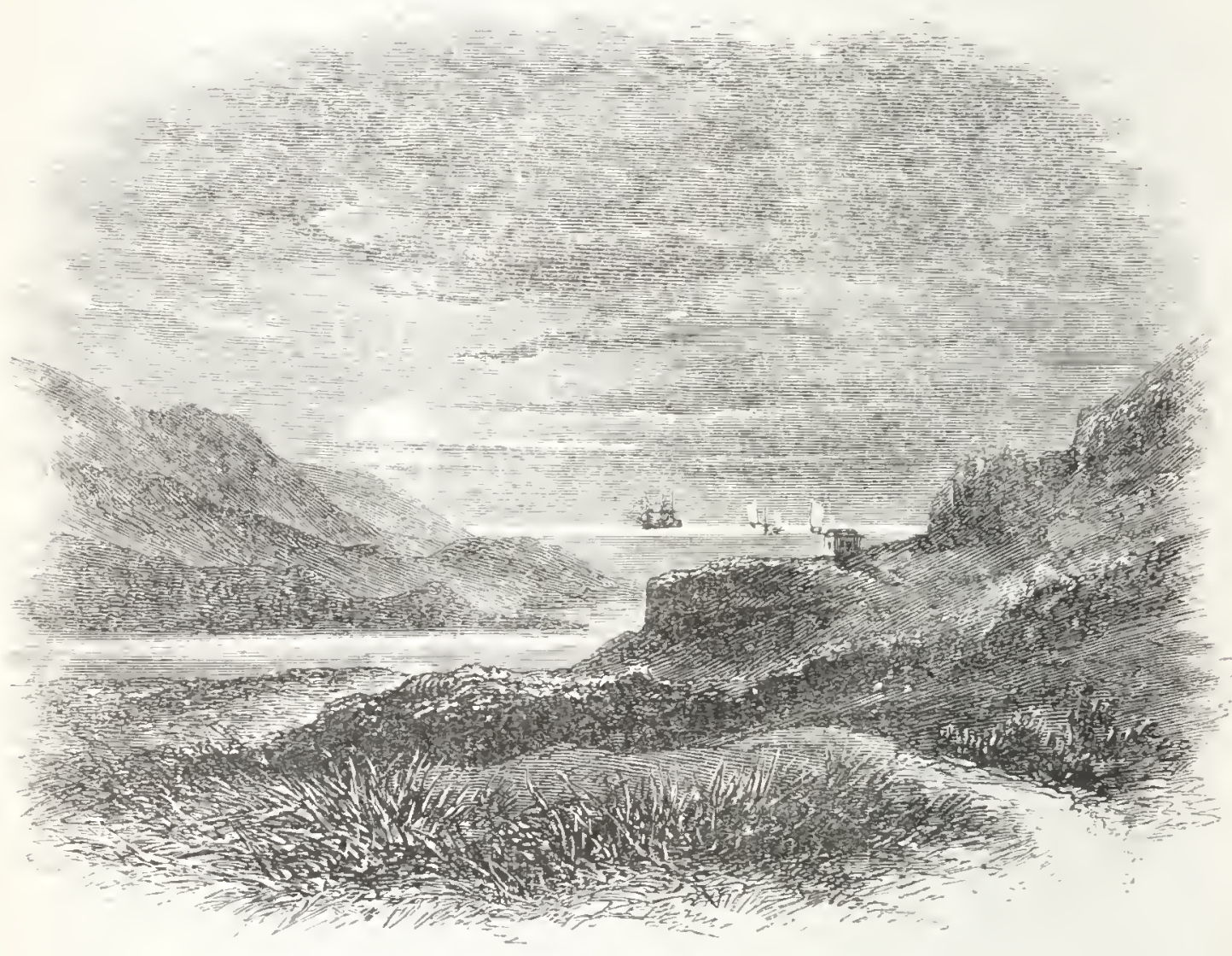

MIOUTI OF STRATH FALLADALE RIVER.

hence, I suppose, the name Strath Hollowdale, or Halladale-half Highland and half Norse. The strath was, in my opinion, once an outlet of the sea, just as Loch Tongue and Loch Erriboll are now."

His sixth exploratory ramble was one of the most interesting of all. He set out a little before two o'clock in the morning, and went towards Loch Haellan, about ten miles east of Thurso. He observed how small an 
elevation of the sea, or a depression of the land, was sufficient to enable the land to be covered with water, and unite Dunnet Bay with the Pentland Firth.

He went north to the Burn of Ratter, and found the boulder clay thickly charged with marine shells $\mathrm{He}$ next went in the direction of Barrogill Castle, on towards the sea, to the Haven of Mey, where he found a bed of boulder clay 60 feet thick, charged from top to bottom with marine shells.

"Here then," said he, "is the grand key to the whole mystery! When the sea stood sixty feet high at Barrogill and its vicinity, the whole of the eastern parts of the county, round to Wick, were drowned!"

"Where the Burn of Ratter enters the sea, the coast is very low, and there is a continuous valley on to Loch Scister.

"The bitterest opponent of geological deductions could hardly fail to be converted by an examination of the boulder clay precipices at the Haven of Mey. He would find that the boulder clay was a distinct formation-a generic production,- -differing entirely from every other thing on the earth's surface. It is not a conglomerate. It would never, though consolidated, form a bed of rock similar to conglomerate. It is not a production of the Mosaic Dehuge. It is not, strictly speaking, a production of the sea. It is not the sweepings of a sea-shore. No! nothing of the kind. No Mosaic Deluge could have produced those beds of dark, bituminous, sandy, tenacious, stony clay. No ocean waves alone, by the friction of ten thousand years on 
rocky strata, could have done it. No! Tens and hundreds of millions of steam-mills, grinding stones night and day for a thousand years, could not have done it. No sea casts up anything like it. It is a distinct generic production, fairly entitled to a place by itself. An observer at Barrogill could not fail to see all this. He could not fail to see that the shore beneath, and along the foot of these clay cliffs, contained a bed of sand, broken shells, and rolled fragments of stones; and yet this bed is entirely different.

"Along the shore, in some places, there is a newer formation than the boulder precipices atop - a formation laid down at the foot of the cliffs, at unusually high tides. It is thickly charged with broken shells, in some places nearly consolidated to stone; yet this formation is much newer. It is, in comparison with the other, a thing of yesterday. The deep ditches dug through the Moss of Mey exhibit no section similar to the genuine boulder clay. They are too marly. These low-lying grounds seem to have been, for a long period-ere the peat grew over them-overspread with shallow pools and lochs of fresh water, in which Limnæa and Cyclas had lived, multiplied, and died, by millions-leaving their empty dwellings to crumble down and mix with the sands over which they had crawled. Apt emblem of man 'in his best estate'! Surely we all walk in the same vain show.

"A beautiful illustration of this is to be seen in the little loch of Mey. It is a very shallow pool of fresh water, nearly flat, but deepening a little towards its 
lower end, where a stream goes off to drive the mill of Mey. Its eastern shore was strewn with sand, and not long ago, the mimic waves had dashed across it, leaving, in the circles of its upper reaches, straws, sticks, and bits of peat. Stooping down on my knees to scrutinise the sands, I was surprised to find innumerable multitudes of Limnrea and Cyclas,- the whole mingled with the Old Houses of a small Caddis-worm.* The sight was impressive. Here was a miniature representation of geologic fact. Thousands of organic existences suddenly terminating their little span of life, through no fault of their own, but by the seeming accident of a sudden shower!"

* Caddis-worm: or Case-worm. 


\section{CHAPTER XV.}

\section{END OF CORRESPONDENCE WITH HUGH MILLER.}

Hugh Miller corresponded regularly with Robert Dick during the preparation of his later works on geology. He sent him the proof sheets of his fortheoming books for the purpose of having Dick's corrections. Even as regards the Old Red Sandstone-Miller's first geological work-Dick furmished him with many additions and corrections. For instance, he sent him the first specimen of the gigantic Holoptychius found under the lower beds of the Old Red Sandstone, which enabled Hugh Miller to correct the theory set forth in the two previous editions of his book.* Dick also enabled Hugh Miller to determine positively that Dipterus and Polyphractus were one and the same fish.† Dick also furnished his friend with numerous specimens of the Diplopterus, Osteolopis, and Asterolepis, accompanied by drawings of these fossil fishes. When sending them, Dick said, "I am far from attaching any value to these drawings. To me labour is its own reward. You can cut and carve out of them as you please."

* See Miller's Old Red Sandstone. Note to the third edition, and note to p. $176 . \mathrm{Ed} .1875$.

+ Letter to Charles Peach, 12th August 1859. 
Hugh Miller's Footprints of the Creator was published in 1849, and here also we find numerous indications of the assistance which he had received from Robert Dick. Professor Agassiz, in his preface to the last edition of the book, says, "Many points respecting this curious fossil (the Asterolepis or Star-scale) remained to be determined; and it was fortunate for science that Mr. Miller was enabled to accomplish this object by means of a variety of excellent specimens which he had received from Robert Dick." "The remains of an Asterolepis found by $\mathrm{Mr}$. Dick at Thurso indicate a length of from twelve feet five to thirteen feet eight inches.... A specimen of Asterolepis discovered by Mr. Dick among the Thurso rocks, and sent to Mr. Miller, exhibited the singular phenomenon of a quantity of thick tar lying beneath it, which stuck to the fingers when lifting the pieces of rock. What had been once the nerves, muscles, and blood of this ancient ganoid, still lay under its bones. The animal juices of the fish had preserved its remains by the pervading bitumen, greatly more conservative in its effects than the oil and gum of an Egyptian undertaker."**

The first cranium of the Asterolepis figured by Hugh Miller was imperfect. Robert Dick furmished him with a perfect one. There was a gap in the print which struck Professor Sedgwick as being unnatural. He said it was "not of the proper finish." But after Dick had furnished his specimen with the keystone-shaped plate in its proper place, Miller says he referred the professor

* Hugh Miller's Footprints of the Creator, p. xxvii. Ed. 1876. 
CHAP. XV.

to the geologist at Thurso "as the true authority for determining how nature had given the last finish to the cranial buckler of the Asterolepis. 'Ay,' he exclaimed, as he eagerly knelt down to examine the specimen, and passed his fingers over the keystone-like plate,- 'Ay, this is a finish of the right kind! This will do!" "* Dick also furnished Mr. Miller with a well-defined jaw of the Asterolepis, and with a drawing of a section of its tooth, which appeared among the illustrations of the book.

Dick found for Mr. Miller-upropos of a conversation which the latter had with Professor Owen-a specimen of the Diplopterus, which fully confirmed the professor's views as to the prolongation of the brain of that fish. In fact, there was scarcely a subject on which Hugh Miller wanted further information, but Robert Dick was ready to supply it. It was a delight to him to labour night and day for the benefit of his friend, and also for the benefit of science. In one of his letters to Hugh Miller he says- "Your letter found me asleep, kneedeep in fern howes. But now I am awake, and busy night and day."

Hugh Miller, on his part, was ready to acknowledge the obligations which he owed to his friend. At a lecture delivered by him before the Physical Society of Edinburgh "On a Suite of Fossils, illustrative of the relations of the Earlier Ganoids," he said, "There are several rare and a few unique fossils on the latter, illustrative of various points in the structure of the first

* Hugh Miller's Footprints of the Creator, pp. 73, 325. Ed. 1876. 
ganoids, to which I can only refer the members of the Society as worthy of their examination. They are in part the fruits of a leisure fortnight spent this autumn among the rocks of Thurso; but in still greater part I owe them to the kindness of my indefatigable friend Mr. Robert Dick, of whom I may well say that he has robbed himsclf to do mo service."

The same lecture is full of the obligations which he owed to Robert Dick. He pointed to the Homocanthus arcuatus, which, though found in Russia, had only recently been discovered in Scotland by his friend. To him also he owed the Hoplacanthus marginalis, another Russian placoid of the Old Red. There was also a magnificent specimen of the Asterolepis, which had enabled him to determine the place and form of a thicklytubercled, well-marked place on the middle of the palate. This also had been sent to him by Robert Dick.**

In sending this fine specimen to Hugh Miller, Dick says-"I give it you most cheerfully. Your kindness deserves it. To any other I would not have parted with it." At the same time he sends him the jaw of a fossil fish, showing the outer row of teeth. "Looking" at them with the glass," he says, "they show a very beautiful star-like arrangement of the channel through which nourishment flowed to the tooth."

Dick continued to correspond regularly with Hugh Miller. He spoke to him very freely. He thought that he was sometimes twisting geological facts to suit a religious theory. Dick thought very little of "authori-

* Hugh Miller's Footprints of the Creator, pp. 334, 341. Ed. 1876. 
ties," but he greatly valued facts-tested and re-tested. "It is not," he said, "by driving along the public roads; strolling along the sea-shore; taking a distant view of Morven through a-spy-glass, that the depth of the Caithness schists is to be ascertained. No! The very fact that the schists dip in almost every direction inight have led 'authorities' to suspect that the granite was not confined to primary hills; but, like the stately oak, sent out its branching roots far and wide. Y.ou, Mr. Miller, rule solely by 'authorities.' Your humble servant has often found them sleeping, and has no reverence for them."

Indeed, Dick had no hesitation in correcting the very highest authorities. "Nothing," he said to Miller (26th September 1850), "is more at fault than the idea sought to be established by Sir Roderick Murchison's section in the front of your volume on the Old Red Sandstone, that the general dip of Caithness rocks is all in one direction. No such thing! I candidly tell you that 'my masters' must revise their views before I can feel the smallest respect for what they say about Caithness. I cannot resist the evidence of iny senses. Take, for instance, the Hill of Buckies, which you saw. The rlip there is north-east, whereas at Thurso the dip is north-west.

"Of course, I am very far from wishing you to meddle with the findings of men driving along the public road and viewing the country from gigs! No! But it is my misfortune to laugh outrageously during my rambles

* Thie Hill of Buckies, so called from the large quantity of marine shells found there. It is not far from Thurso. 
to find the Caithness rocks dipping in every airt* of the compass, whereas it is stated in geological books that they dip in only one direction!"

Robert Dick was not afraid of correcting Hugh Miller himself. In one of his letters he says:- "You have fallen into error in your Old Red Sandstone. You have described Caithness as a vast pyramid rising perpendicularly from the bases furnished by the primary rocks of Sutherland, and presenting newer beds and strata as we ascend, until we reach the apex.

"Now, Mr. Miller, this is not only incorrect but calculated to deceive. But you are not to blame. It is the getters-up of the geological maps who are to blame. You work by the geological maps. Geological maps and treatises are got up by men in red-hot haste, on data proved to be erroneous years ago. New books, with nothing new in them but the paper and ink! The public are gulled, and the poor student, panting for knowledge, fills his belly with husks, and by and by he regards his new books with derision!

"I am working very hard-sometimes seeking new fossils but finding none; sometimes rambling far over the hills and finding a junction of the Old Red very different indeed from the respectable 'authorities' in Edinburgh. As for the maps, I have handed them over to the devil as the most detestable pieces of imposture ever obtruded on a discerning public. 'Discerning' indeed!

* Direction. - " Of a' the airts the wind can blaw, I dearly lo'e the west."-Burns. 
"Your Edinburgh Professors can put on their spectacles next time they travel north. If they wish to be respected, they must be a little more particular."

Dick himself had bought one of the best maps of the time. He used it for travelling purposes. He noted down on it the direction of his journeys. He marked the dips of the strata in nearly every part of the county. He noted the disturbances, the faults, the beds in confusion, the sites of the boulder clay, the flagstones, the red sandstone, the gneiss, the conglomerates, and the various geological formations of Caithness. The map is full of his marks. In some places, where a river or a loch is put, he marks "nonsense" or "stuff," meaning that there is no such thing. This map must have been his pocket-companion for many years. Underneath it he writes:- "I have been rambling over Caithness since 18:30, and anything more unlike the truth than the above picture I have never seen. There is no pleasure in marking anything on it. I have made an attempt to put in roads. The dip is often seen by the road-sides."

Writing to Hugh Miller about the geological maps of Caithness, he said :- "It would be easy to construct such a plaything as those maps of Messrs. —_, _ - and — but when you had done so, would the toy meet the felt necessity? . . . O brave gentlemen! bold men and daring! how gallantly you have set the truth aside! - here laying down your fancy ovals, there your halfmoon patches! just as if Nature were strictly bound down to mathematical figures, squares, and circles. How inimitably you have run your old Red in Caithness 
sheer up to the root of Morven, in defiance of every intervening obstacle. Outbursts of granite are nothing. No! Their iron-pointed crests (stubborn facts) standing up here and there are only trifles, yet they riddle in rotten holes your pretty pictures! . . . For on such things men now-a-days found their Deep Philosophy.

"Seriously, if any junction of Old Red with the granitic rocks be as irregular and complicated as that in Caithness, it will be no easy task to delineate it correctly; and unless it be correctly done it will be of no value. It would require such an amount of time and patience, such a crossing and re-crossing of the county, as few private individuals could venture on.

"For my own part, though I grumble at toil as little as any man, I have, so far as regards any serious intention of doing such a thing, given it up. At the same time, as I ramble now and then, I will have an eye to it, and that is all. Let the Government do it; they only can order it to be done properly."

Then, about the new-fashioned ideas about geology he said:- " 'Since the fashions,' to use your own words, ' have not passed away,' how provokingly strange will you deem it, if you and the rest of your scientific brethren settle down at last to the conviction that this earth never saw a creation but oNE. . . Though difficulties and doubts innumerable stand in the way, they may yet be brushed aside like morning mists, and the simple truth shine forth clear and luminous as the sun. ... See! says some observer, the dreams of our wise men! They tell us that the dead animals entombed in 
the solid rocks do not belong to one creation! and behold, they still exist. The animal whose shell they name Nummulite still lives in the Mediterranean. The Pentacrinite lives in the West Indian seas and in the bay of Dublin.... Your 'Theory of Degradation' is at least a very ingenious piece of pleading; but if $\mathrm{I}$ am right in supposing that it rests mainly on the idea that no reptiles existed during the period that the lowest fossiliferous strata were accumulating, then I say you may yourself live to re-write that part of your story. In the progress of discovery, the whole series of geologic speculations may change. From the very nature of the investigations, an element of uncertainty must for a long time mingle in all your most valued performances. That stern, startling fact of ferns in the Orkney schists must in no small degree tend to unsettle all fixed belief in the findings of the stone philosophers, if, indeed, any belief can really belong to them."

At Miller's request, Dick again went out to do his biddings. "Referring you," he said (24th December, 1849), to a promise I made to you when down at Thurso, to examine the groovings and polishings, by removing a little of the soil in the locality in which you detected those marks, I wish to remark that the work is done. You might think me dilatory and slothful, but I could not accomplish it sooner. In the first place, the business was retarded by a severe frost. Winter held his iron rule; and could you have seen the place over which you rambled in July last, you would have beheld a strange metamorphosis. The strata were wholly covered with 
sheets of ice, with long fantastic icicles hanging from every precipice. The air was still, and the sea without a ripple. Of course nothing could be done; it was too icy, too cold.

"The scene changed to another phase, not a whit more endurable. A cold, 'blae, eastlin' wind, accompanied by driving sleety showers, whistled along the watery turmoil. This was followed by a close, dense, foggy drizzle. Bogs and mires were impassable to ordinary folk. Patience said 'Wait.'

"Well, I waited. Winds and rains are but a tide. The eastern sky at length frowned, and stormed, and wept itself into sheer good humour. The air became dry and mild, and a delightful morning at length dawned. I took up my spade and went off to the spot, in order to solve your query."

"I remember that I was much struck by the phenomenon, when you pointed it out to me on the top of yon dizzy precipice. I was no less astonished on seeing it a second time. To me these wonders are never old. Their edge never dulls. They always stir me.

"I laid bare the rock for about two feet. I did not feel entitled to do any more. I felt I had no right to strip the soil off any man's property, so I desisted. But it was quite enough. The rock, beneath the soil, was polished and grooved, in even a more beautiful manner than when you saw it. The bearings of the groovings and scratches were, as near as could be determined without a compass, west and east.

"On coming homewards, I noted, at a spot where 
Lady Sinclair had caused a small runnel of water to be diverted in order to form a mimic cascade, a good piece of the rock laid bare of the soil; and the surface of that rock was grooved and polished similar to the other."

This unmitigated hard work injured Dick's health. He did not sustain himself properly. On his long journeys of forty or fifty miles he had only a little biscuit to eat. He drank from the nearest spring. There were not only no public-houses along the districts which he travelled through; but no houses of any kind. There were only moors, and mosses, and mires.

On the 28th of January 1850, he sent Hugh Miller the head plate of an Asterolepis. He found the heavy stone in which it lay concealed, five long miles from Thurso. He hammered and chiselled, and took out the stone himself; but he could not carry it away. He hid it until he could get some help. He hired a man, and the two went out in the dark with a wheelbarrow to bring it home. It was a very heavy stone. They carried it "up the brae at the shore," and placed it carefully in the wheelbarrow. The two trundled it home, turn and turn about, until they reached Dick's house in Wilson Lane, late at night. In a future letter to Hugh Miller he says:- "Truly the labour of digging it out has nearly finished me. I worked too hard, caught cold afterwards, and I am no better yet."

On Miller's asking him to go out and further observe the groovings on the hill-sides, he says:- "The thing shall be attended to. But, $\mathrm{Mr}$. Miller, I have not been to the hills this winter, not since October. Not 
that I am forgetful or unmindful of such affairs. But many conflicting cares will be creeping in and annoying one. Thus the course of stone love cannot run smooth. For three weeks and more I have been grinding the few stones I have into something of a neater shape, rendering them less cumbrous and more trim and smooth. Truth to say, it is hard work, and requires enthusiasm. Geologists should be all gentlemen, with nothing else to do."

The means by which Dick sawed and polished his stones, were very simple. An old cask about the size of a herring barrel set on its end, and supporting a board or flat stone, was his bench. He had a short portion of the common hand-saw, fitted by himself with a rough wooden handle. With this, and the addition of a little sand and water, he trimmed the stones containing the fossils, and afterwards polished them by rubbing the two surfaces together. This work is generally done by machinery; but Dick did it all by the strength of his arms. It occupied a great deal of time, and was often very heavy labour.

Hugh Miller plied Dick very hard. He was constantly writing to him, asking for further information. Mr. Miller was then contemplating his new book-The Testimony of the Rocks-for the purpose of reconciling geology with the Mosaic account of creation. The matter of the book was first delivered as lectures. "You ask me," said Dick, "what good news I bring you from the shore, from the quarries in the hills, and from the quarries in the plains?" I answer, simply no news at all. 
"Since February last, I sauntered east, I sauntered west; in fact, I am almost as familiar with every rocky ledge sixteen miles on every side of this place as you are with the desk before you. I have peered into them all, and still there is no news. Old Boniface ate his ale, drank his ale, and slept upon his ale. So may I say, I have ate on the strata, I have hammered the strata, and sometimes I have sat down and fallen asleep on the strata; and, after all, I am not one whit the wiser.

"One sunny morning I found myself on the seashore at Barrogill. I had been there before, but I was never so sure of achieving wonders as I was on this occasion. The Pentland tides had receded to the lowest ebb, and the whole range of stratified schists lay dry and inviting. I set gallantly to work, and charged along one ledge and down another; up a third, and across a fourth ; retreating, advancing, wheeling, kneeling, poking, poring; now to the right, now to the left; then the last tremendous assault, and all is over, save 'Try again.'

"Well, I found a bed of very dark bituminous schist, very dark whilst wet by the sea. It almost seemed of a coal colour, though the stone, when dry, is brownish. In fact, the strata differ in nothing essential from similar bituminous beds at Brims and near Thurso. In those strata I found nothing, save detached scales of Diplopter'us, droppings, detached spines of Cheiracanthus, and bits of broken bones of Coccosteus. Here and there, in those beds, lay roundish and irregularly shaped darkcoloured pellets, of what looked like bituminous nodules. 
... I turned away, and wound my way Dunnet-wards, examining every accessible ridge on my way up. There is a wondrous similarity among the rocks of Caithness everywhere, though from the Haven of Mey up to Scarskerry they are charged with iron to a greater extent than in any other spot. At the little Mill of Mey they are literally red as keel, and, tilted up at a high angle, dipping north-east. ... As I passed on, looking down from the rocks, I could identify the dark Barrogill bed, buried deep beneath those rough red strata. And in some gyoes I exclaimed, as I looked down, 'There's Thurso beds! and there, and there!'

"Near Scarskerry, at a jutting promontory, the dark bituminous beds, and grey limy beds, many feet in thickness, are seen tilted up at an acute angle, thin, slaty, rugged, and hard, and across their sharp edge the chafing waves roll twice every day.* I had marked them often as I passed along at former visits; but the white surf had debarred me of the pleasure of a reconnaisance. But this time 'twas all right, and I plied the hammer where hammer had never been plied before. ... I found a few broken fragments of Asterolepis, scales of the same, and a few scales of Diplopterus.

* In another letter to Hugh Miller, Dick says :-- "You know Nichol's Architecture of the Heavens, and his plates of the Nebulae? Well; many of the cnds of our flagstones resemble them-a series of star-like forms, set upon a jet-black ground. Is it not extraordinary that upon the end of a stone there should be rescmblances to a series of forms traced by telescopes in immcnsity? Indced no! All Nature is alike. The ripple-mark may any day be seen in the clouds, as well as on the sea-shore, or in the rocks." 
Not another article did I find, although I tried until the incoming tide threatened to cut off my retreat to the land. And then I fled."

Dick went on with his ramblings, and sent, as usual, the results to Hugh Miller. He went to Barrogill and Gills Bay on the Pentland Firth, marking the dips of the flags and red sandstone. At the junction of Gills Burn with the Firth he found several beds of bituminous shale, containing fossil coprolites and large seaweed plants not unlike a stout bough. This was afterwards engraved in Hugh Miller's Testimony of the Rocks. Dick found the beds of clay slate interlacing with the huge mass of red sandstone before him, and up Gills Burn he saw a beautiful section of boulder clay. "No less than three little streams have cut their course through the boulder clay, laying bare their internal structure most beautifully. In one of those little streams you walk up into the very bowels of the earth, with a perpendicular wall on each side of you, picking out at your leisure Crassena, Mactra, Cyprina, Turritella, Dentalium, chalk, flints, pieces of Oolite, and such like.

"Freswick Burn is nothing, Harpsdale is nothing, the Haven of Mey is nothing to a geologist, compared with this. I wish you no higher gratification than an hour spent among the clay and shells at Gills Bay. This section is noticeable because it exhibits at the base, just where it rests on the red sandstone, a bed of gravel and shells-broken and intermixed togethera thing I never saw in connection with any other section. I have seen, here and there, small gravel nests of 
various shapes, but never at the base line. In truth, I do not remember ever seeing the base line of a section of boulder clay until I saw this one."

From Gills Bay, Dick went westwards to the bay of Scotland Haven, where he found various remains of the Asterolepis. He brought away a few of them, more by way of memorial than because of their value. "The slates from this locality on to Dumnet," he says, "dip east-north-east, and in many places they are in complete confusion. As I passed liomewards, my thoughts reverted to the ignorance of those who imagine that Caithness strata have in general one particular dip-one 'general dip.' A greater delusion never entered the brain-box of mortal man."

Dick's next ramble was to Bencheilt, about twentyfive miles south of Thurso. His wish was to examine the granitic débris, and to correct the observations made during his midnight journey to Dunbeath about three years before. He went by Sordal and Spittle Hill, where the strata dipped east. At the thirteenth milestone, he found the granitic débris, and it continued to Stemster Hill. Passing a Druidical pillar, nine feet high, he went on to Bencheilt. He was twenty miles from home. His time was nearly up; yet he determined to ascend the mountain. Observing, however, that the Loch of Stemster was close at hand, and that a Druid's temple stood on its side, he resolved to go over and see the great antiquarian monument.

"The Druidical temple," he says, "is not a circle. It is shaped like a horse-shoe-like an old-fashioned 
reticule basket, or rather like an old wife's pocketpardon the simile. The stones are from the hills around. The highest stone may be six feet high; their average height about four feet. They are grey, moss-grown, and lichened; and upon some of their points the hammer of the antiquarian has hit very hard. At the north-east corner is a small space, outside the circle, at the foot of a large stone-the second stone in the end row,-at which some person has been digging for relics, and has left it half open. The small space looks a grave, as if some one had been buried there atter sacrifice.

"Returning to the west end of Stemster Loch, you observe a small stream runs out of it down to Loch Rangag. This little stream I traced from the one loch to the other. I traced it very patiently, and was rewarded and delighted.

"Where the burn runs out of Loch Stemster, there has been dug a sort of watercourse, and a sluice-gate has been put in. They have cut through the strata, hard clay stone, and bituminous stone, with the same abrupt dip to the east. You go down the stream, over the edges of the strata, still dipping east. On and on, and still the dip is east. Going on, over their edges, you are arrested by a bed tilted south! Dip south. Close in contact, you find a bed on end!-broken fragments, angular, gneiss-looking, hard, bound together by three seams of lime crystallised. Disturbance and even trituration have been at work. On a little. The strata wheel round again to an easterly dip. Down, down, and down - down even to the Mill, and even below the Mill; and 
the same beds, bed over bed; what a pile! The distance between the two lochs is about a mile on the map. During half of that mile, you descend the strata, bed upon bed, stair-like; about 2625 feet. Then up above Loch Stemster another hill overlies all this thickness of rocks! You are perfectly safe in estimating the thickness of the Slate beds."

After he had made lis observations, he returned home with all speed. The bread must be made and baked, and the bread must be sold. His hard day's work in the mountains was followed by a hard day's work in the bakehouse.

"A long period elapsed before Dick again corresponded with Hugh Miller. The latter was editing the Witness, and preparing his admirable book entitled My Schools and Schoolmaster's. Dick had again returned to his study of botany. But the correspondence seems to have been resumed towards the end of 1854 . In a letter written by Dick to Hugh Miller, he says, "When Satan once appeared where he ought not to have been, and was asked 'Whence comest thou?' his answer was, 'From going to and fro in the earth, and walking up and down in it.' Now, what could you expect from any deil's bairns but only a reflex of their father's conduct? I too have been going to and fro in the earth, and walking up and down in it; with this difference, however, that I have had the very best intentions. And though Satan's palace chambers are said to be paved with such, I hope he shan't have any of mine for flagstones-more particularly as my acts have been of the 
most innocent lind,--scorning to mock the use of any living thing,--not even rudely crossing the stray ideas of any fellow-geologist.

"I have been admiring the fashion of the grass of the field; not only admiring but collecting it; not only collecting but studying it. In the prosecution of the study, I have made hundreds of laborious journeys. I have ransacked the coast,-rambled inland over moor, mire, and meadow - up hills and across valleys-peeped into running streams and stagnant pools, goose-dubs and dismal lochs. Finally, I have been twice on the pinnacle of Morven - the Mont Blane of Caithness.

"Nor has the peculiar study that you favour been forgotten. I have made many journeys expressly in search of fossils, or to examine some particular stratum. I have regularly visited the boulder clay after rains and storms-kept a keen eye after all the slate quarriesand even spent days in scrutinising Dunnet cliffs. True, in March 1854, I clambered down the West Front, more than two hundred feet, and examined, searched, and hammered for hours; and my only reward was a curious thing, which is still a problem. Splendid sections are those cliffs. How strange one feels, crawling along their feet, and looking up their perpendicular height! What mites, what trifles we are amidst the might of earth and the vastness of ocean!"

Hugh Miller was at this time very much annoyed at the leaders of the sect of which his newspaper was the organ. "I see," says Dick, "that you are not in heaven as to peace any more than $\mathrm{I}$ am. Yet 


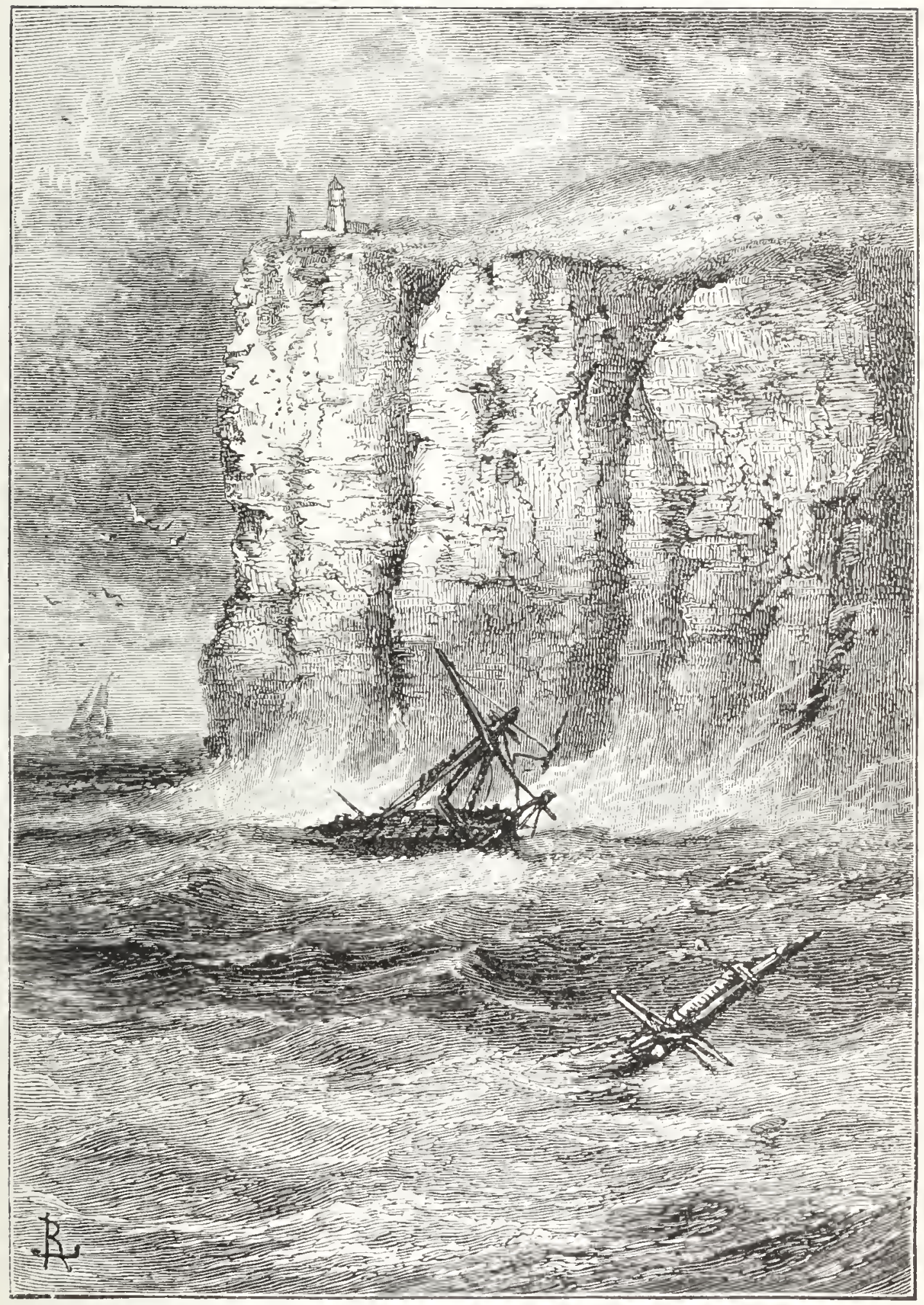

DUNNET HEAD: IVEST FRONT-NEAR THE LIGHTHOUSE. 

I candidly say that it is very hard that you cannot enjoy yourself for one day among the rocks, without being assailed for it by ignorant W. W.'s be they clerical or not. Great stir about tyrannical Popery at present; but query-may there not be among ourselves Moderate Popes, Free Popes, and such like? Plenty, I guess. The divine right of ruling is worth ten times the stipend."

In acknowledging the receipt from Hugh Miller of some papers containing an account of the meeting of the British Association at Edinburgh, Dick says- "These papers are not thrown away. They shall be duly pondered and considered-ay, on mountain tops, even at early dawn, or sober eve, when the twinkling stars and the soothing winds tell their own tale of nature's happiness in their own dear way.

"It is a blessed thing that creation smiles or frowns, laughs or is sad, just as we are content or otherwise. Every man according to his 'gift.' Sooth to say, I am one of those whose faith is too weak to see every one of the many twinkling orbs that bedeck the vault of heaven - the abodes of beings who suffer and of beings who rejoice-of beings who are saved, and of beings who are lost. No, no! I have thrown Calvin's theory to the winds. There are as many Gospel theories as there are geological; and all are at liberty to behold their own likeness in their own mirror. Only one thing. If divines have for centuries been preaching nonsense about the creation of the world and of man, what confidence can an ignorant man have in their findings and 
interpretations of other parts of the same writings, equally full of interpretations, corrections, and amendments? I know what I say."

The correspondence proceeds at intervals, until the death of Hugh Miller, which took place on the 24th December 1856. He was then preparing the last sheets of the Testimony of the Rocks, which was published at the beginning of 1857. Dick was of opinion that Hugh Miller published the book quite as much to please the dominant religious party in Scotland, as to satisfy the convictions of his own mind. Indeed, he traced the beginnings of Hugh Miller's insanity to the over-stimulation of his brain, for the purpose of meeting the exigencies of his position as a scientific man and a religious journalist. Some time before the sad catastrophe of Hugh Miller's death, he mentioned to Professor Shearer a curious symptom, indicative of commencing insanity in this gifted man.

The following are Professor Shearer's words:- "I had an interview with Mr. Dick in the inner shrine of his daily labours-his bakehouse. This was considered a high mark of his consideration; and indeed his manner was perfectly cordial and natural. Our conversation naturally turned upon his friend Hugh Miller, then not long dead, and to his books. His powerful and brilliant effort to reconcile the scriptural account of creation with geological science, Mr. Dick considered a failure. At the same time, he strongly maintained the doctrine of successive creations of animated beings, though he appeared to have no confidence in the Darwinian doc- 
trine of development. Pointing to the sketches of the Greak boy and the ape on the walls, he asked, "whether that could come cut of this ?'

"Returning to Hugh Miller, I naturally expressed my sorrow that a life so brilliant and valuable as that described in his Schools and Schoolmastcrs, should have ended so sadly. 'Ah, poor Hugh!' said he, 'I knew him well. His life, as he could write it, would be as interesting as a romance. But I am not at all astonished at the way it ended. His mind was touched somehow by superstition. I mind,' he continued, 'after an afternoon's work on the rocks together at Holborn Head, we sat down on the leeside of a dyke to look over our specimens, when suddenly up jumped Hugh, exclaiming, 'The fairies have got hold of my trousers!' and then sitting down again, he kept rubbing his legs for a long time. It was of no use suggesting that an ant or some other well-known 'beastie' had got there. Hugh would have it that it was " the fairies'!" *

"When the news of Hugh Miller's death came," said Dick to his sister, "I thought it was the end of all things. I was more shocked than I could tell to anybody. Poor Hugh! I knew him so well! I shall always remember him. Indeed, he is now, and almost always, with me. I cannot look on a stone without thinking of him. I am not likely ever to forget him. He was sorely afflicted with his head while he was

* Hugh Miller wrote a good deal about the fairies in his works. See his description of the Fairies of the Ravine of Eathie, in Oll Red. Sandstone, pp. 221-2, Ed. 1875. 
here, and to such a degree that neither you nor I can form any idea of his sufferings. Peace to him! He will live long over all the earth."

Again writing to his sister, he says, "Mrs. Miller has sent me Hugh's last Testimony of the Rocks. I have read it frequently. It contains a great deal of good writing; but it leaves the great point as far from being settled as ever. I am surprised at his mode of handling the two records-the account of creation in Genesis, and the facts as we actually find them; for it is an undeniable fact that all our present dry lands are full of dead animals. But don't mistake me. Mr. Miller has produced an unmistakably clever book, which will sell fast and become popular. But it does not solve the great problem; neither is it in harmony with the account of creation recorded in the oldest book extant. Nor will it convert geologists, and satisfy those who know anything about rocks and organic remains.

"Possibly the business cannot be settled in the present stage of discovery, and friend Hugh had rather too much veneration for sundry great living men, to strike out a new path amid such an entangling forest of conflicting opinions. Of one thing you may be sure. The earth, as we have it, was not made in six ordinary days. The earth is making yet. It is still in course of creation."

Strange to say, when the Life of Hugh Miller came out, not a word was said about Robert Dick. The two had been in communication for more than ten years. Dick returned to Mrs. Miller all the letters he had received from her husband, for the purposes of the bio- 
graphy; and more than a hundred of Dick's letters were in the possession of the biographer. Dick had given all his best fossils to Miller. "He robbed himself," said Hugh Miller, "to do me service." Dick worked night and day to enable him to illustrate his works by new specimens. One would have thought that these services were worthy of some mention in Hugh Miller's biography. But not a word is said there as to Hugh's greatest helper. 


\section{CHAPTER XVI.}

CHARLES W. PEACH, A.L.S.

While Robert Dick was searching for organic remains among the rocks at Thurso during his leisure hours, another scientific labourer was occupied in the same manner at the opposite end of the island, among the rocks of Cornwall. Robert Dick had discovered numerous remains of fossil fishes in Caithness, where distinguished geologists had stated that no fossil fishes were to be found; and Charles William Peach had discovered fossil fishes in Cornwall, though it had also been stated that the rocks there were non-fossiliferous. While the one was disturbing the echoes of Pudding-gyoe, the other was hammering in Ready-Money Cove. The two were working simultaneously amongst rocks of the same epoch, and the results of their labours were in a remarkable degree alike.

The Cornish worker in science was then but a private in the mounted coastguard service. Like Dick, in his hours of leisure he found time to add materially to the facts upon which geology is based. Thus, at the same time, Hugh Miller, originally a stonemason,-Robert Dick, a working baker,--and Charles William Peach, a private in the coastguard service,-were all engaged 


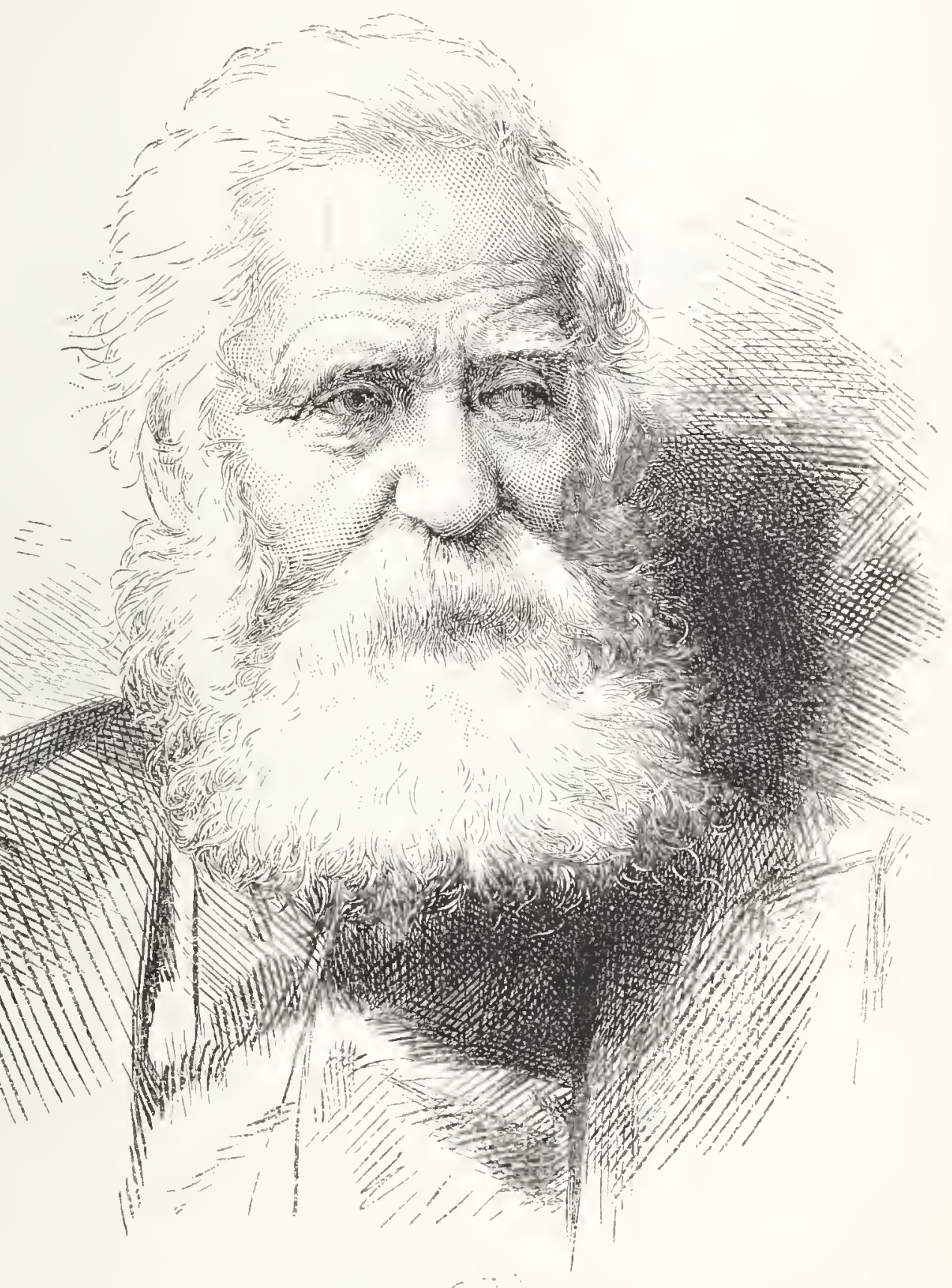

CHARLES W. PHACIT, A.L.S. 

in like pursuits. "It is one of the circumstances of peculiar interest," said Hugh Miller, "with which geology in its present state is invested, that there is no mian of energy and observation, who may not rationally indulge in the hope of extending its limits, by adding to its facts."

While engaged in their respective pursuits, Dick and Peach were quite unknown to each other. They worked on quietly and unostentatiously, without any thought of fame. It might be said that theirs was "the pursuit of knowledge under difficulties." But this is a mistake. The pursuit of knowledge is always accompanied with pleasure, and the pleasure is only enhanced by the difficulties with which it is surmounted.

But circumstances shortly occurred which led to Mr. Peach's promotion in the service, and to his removal to the north-first to Peterhead and afterwards to Wick. Then it was that Dick and Peach became the most intimate of friends. For this reason it is perhaps appropriate to couple the portrait of the one friend with that of the other,--not only because their pursuits during their leisure moments were in a great measure the same; but because it serves as an introduction to the correspondence which follows.

Mr. Peach has told us the story of his life. We think it full of interest. It shows what a man in even the humblest ranks of life may do, to accumulate knowledge and to advance science for the benefit of his fellow-creatures.

Mr. Peach was born in September 1800, at the village 
of Wansford in Northamptonshire. At the time of his birth, his father was a saddler and hamess-maker, but he afterwards gave up the business and took a small inn in the village, and also farmed about eighty acres of land. The time came when young Peach had to be sent to school. He first went to a dame's school, where he speedily learned the A B C. After that he was sent to

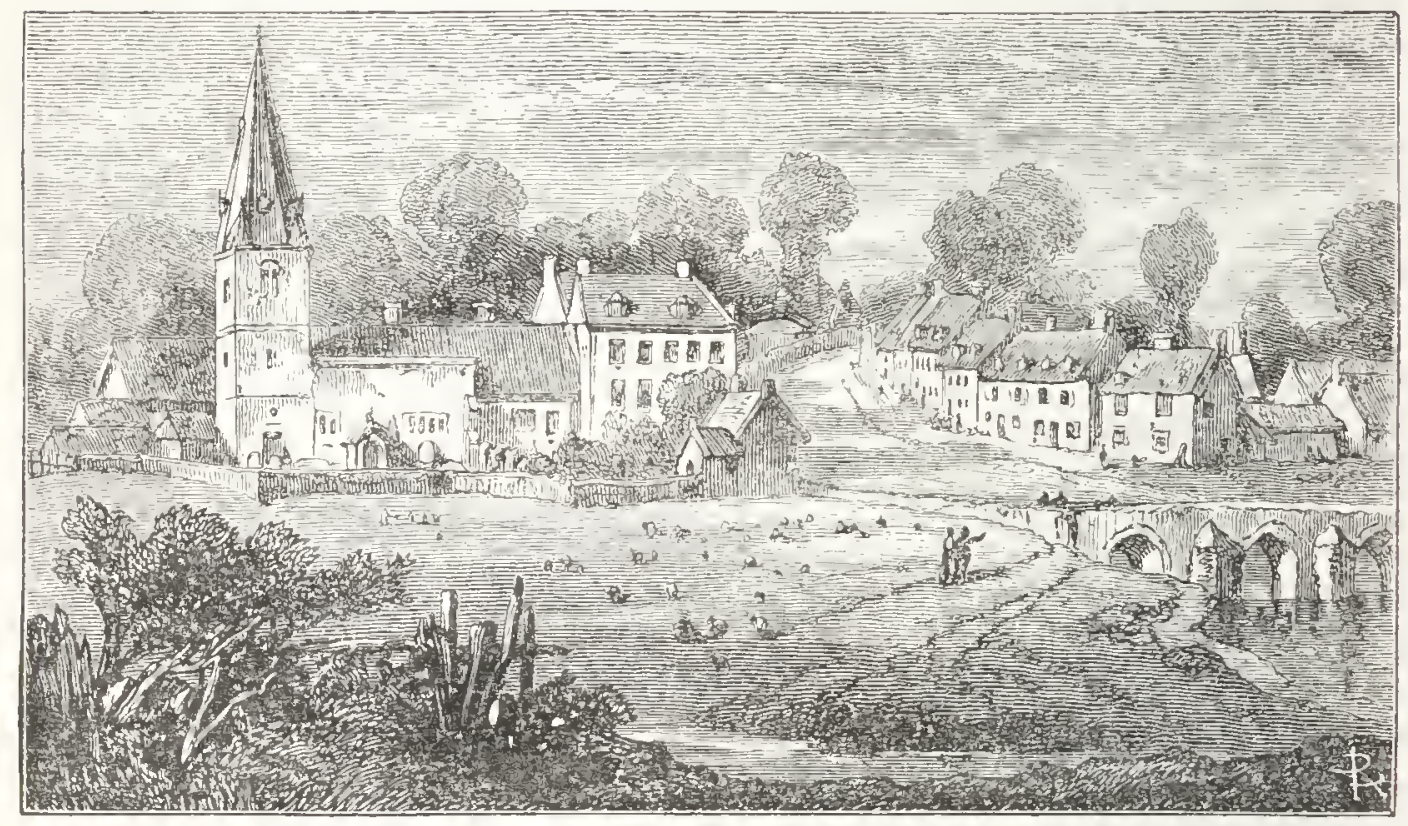

WANSEORD, NORTHAMPTONSHIRE.

the village school, the master of which had been an old sawyer. The man could no longer saw, but it was thought he might teach. In those days any wom-out brokenlegged man was thought good enough to be a schoolmaster. The old sawyer knew very little about spelling. There was not a grammar-book about the school.

But as old Mr. Peach was anxious to make his son a scholar, Charles was taken from the old sawyer's school at twelve years old, and sent to a school at Folkingham, in Lincolnshire. There he made better progress. He 
learnt to read and write well; and he laid the foundations of the ordinary branches of education. He remained at this place for three years, and at the age of fifteen he left school altogether.

He returned to his father's house to help in the work of the inn, and to assist in the labours of the farm. It was not a very good training for a lad. Peach was brought into contact with the people who frequented his father's inn. Wansford was then a very drunken village. Peach was often invited to drink, but always refused, - - a proof of moral courage at an early age. He was consequently called "the milksop" of the house. Perhaps from what he daily saw before him, he determined to abstain from drink. In this way the Spartans taught their children. At all events, though reared in an inn, Peach abstained from liquor for the rest of his life.

Not liking his position at home, Charles applied for the position of riding officer in the Revenue Coastguard. He was appointed in January 1824, and directed to proceed to Southrepps, in the county of Norfolk, and report himself to the commanding officer there. After approval, he was directed to take up his station at Weybourn, in the port of Cley, Norfolk.

At that time Peach knew nothing of Natural History. He had never seen the sea. What a sight, and how full of wonders, it was to him! He was struck with everything connected with it. He wandered along the shore, and found brilliant seaweeds and zoophytes innumerable, the names of which he did not yet know. He 
was particularly impressed by a splendid specimen, which was placed on the parlour chimney-piece of the little inn where he stayed at.* The appearance of the zoophyte strongly excited his curiosity. He determined to know what it was, and where he could find a specimen for himself. This little object had the effect of turning his attention to the study of Nature.

He began to make a collection. He had no book on the subject. He collected, more for the beauty of the forms and the colours of the agates. He would know more by and by. Men in the Coastguard service were in those days turned rapidly about from place to place, for no particular reason, but generally at considerable expense to themselves. After being at Weybourn for a year, Peach was removed to Sherringham, also in Norfolk.

It was while at this station that he met the Rev. J. Layton, then living at Catfield. The reverend gentleman, finding that Peach was an enthusiastic collector of zoophytes, asked him if he should not like to know the names of the objects he collected. "Certainly," was the reply. The clergyman then invited him to his house, and showed him a book containing the history of British zoophytes. He was delighted with the book; but, as it was expensive, and he could not purchase it, he went boldly to work, and copied out the greater part of the

* It proved to be the Antennularia antennina. The description of this zoophyte is accompanied by a brief sketch of Mr. Peach's career, in the second edition of Dr. Johnston's work on The British Zoophytes, p. 86, Ed. 1847 . 
letterpress. Although he had never had a lesson in drawing, he also endeavoured, to the best of his power, to copy out all the engravings. By this and other means, he laid the foundations of a great deal of knowledge of the lower forms of marine life, while carrying on his humble office of mounted guard in the Revenue service along the northern coast of Norfolk.

His business was to look after smugglers, and prevent them landing their illicit goods at any part of the coast. His work was done partly at night and partly by day. He must be constantly on the alert. The mounted guard were not allowed to remain long in one place. After remaining at Sherringham for about two years, Peach was removed to Hasboro. After a year's service there, he was sent to Cromer; then from Cromer back to Cley, where he remained for two years. Here he married, and entered upon a new career, that of bringing up a family on small wages. But he met every difficulty cheerfully. He was fond of home life, and his wife helped to make his home happy.

At Cley he was placed in charge of the station. He superintended the look-out after smugglers, and he did his duty carefully. Notwithstanding this, he was once charged with having neglected it. A jack-in-office, an Irish naval captain in command of the coast service there, assembled the Coastguard before him, and charged them all with being bribed by the smugglers. Peach was justly indignant. He protested for himself and on the part of his men that they were loyal and honest servants of her Majesty, and he challenged the captain 
to prove his words. The captain could not; and accordingly, after a little hard swearing, he drew in his horns, and said no more on the subject.

It may here be mentioned that Mr. Peach was a handy man at everything. He learnt to draw with correctness. He cultivated mechanics. When he went into the Coastguard, he spent part of his spare time in making a turning-lathe. With this he turned jet earrings, jet boxes, and other things. He afterwards made a compound slide-rest, and turned things in iron and brass.

After two year's' service at Cley, Peach was sent to Lyme Regis in Dorset, at the south-western part of the island. He then lived at Charmouth, but he remained there only four or five months, when he was removed to Beer, at the mouth of the Axe, in Devonshire. He remained there for about two years, always working in his leisure hours at zoology and natural history.

He was then removed to Paignton in Tor Bay, farther down the coast. He was not allowed to rest there, but was shortly after removed to Gorranhaven, near Mevagissey, in Comwall. It was here that he indefatigably pursued his studies in zoology. He collected some of the most delicate specimens of marine fauna. Many of these he sent to Dr. Johnston when preparing his history of the British Zoophytes. Others were sent to the most distinguished writers on zoology, and several of them were called after his name.*

It was while living at Gorranhaven that Peact;

* The Isodictyia Peachii, Membranipore Peachii, Lipralia Peachii, Cellularia Peachii, Peachii hastatá, and Eolis Peachii. 
applied himself to a new subject,- - the geological formation of the coast. It had been stated by well-known geologists that no relics of ancient life existed in the Cornish rocks. "We have no exuvir," said Pryce, "of land or sea animals buried in our strata." "The rocks of Cormwall and of Scotland are non-fossiliferous," said Dean Conybeare. The same statement was repeated by many writers, and amongst others by Sir Roderick Murchison, who took the statement on trust. In fact, geology was then in its infancy. During the last fifty years, nearly everything has been changed.

The private in the mounted Coastguard service did a great deal to alter the then state of geology. He was not satisfied with the statements of others. He examined for himself. He had the quick eye and the keen judgment. He possessed the gift of careful observation. Nor was he ever daunted by difficulties. In fair weather and in foul, he worked among the Cornish rocks, and found fossils where no fossils were said to have beenfossils innumerable!

Mr. Peach was not the man to let his light lie hid under a bushel. A meeting of the British Association was about to be held at Plymouth. Plymouth was not far from the place where he lived, and he determined to put his facts together, and read them before the association. He never wrote a paper before, nor had he ever read one. He had only heard one scientific lecture. But with his ready mother wit he prepared his paper, and it proved to be a thoroughly original one. He read it himself at the Plymouth meeting in 1841. It was entitled, On the Organic Fossils of Cornwall. 
"It is impossible," he writes in 1847, "to describe the feelings under which I then rose. That is over long since. The only beating of my heart now about the British Association is, that of gratitude towards its members, and of affection for their great kindness. I feel my love of scientific pursuits strengthen every day. I have taken hold of that which every day affords ' a feast of reason and a flow of soul.".

In the following year (1842) he attended the meeting of the British Association at Manchester, where he read a paper before the Zoological section on his discoveries and observations of the marine fauna on the Cornish coast. In 1843 he attended the meeting at Cork, and in 1844 he was at York. He never went without a paper. Sometimes he read several. Men of distinction began to notice this remarkable coastguardsman. He was acknowledged to be one of the most original discoverers in geology and zoology. Such men as Murchison, De la Beche, Buckland, Forbes, Daubeny, and Agassiz, took him by the hand and greeted him as a fellow labourer in the work of human improvement and scientific development.

Dr. Robert Chambers was present at the York meeting. He wrote a very interesting article on the subject, which appeared in Chambers's Journal of November 23, 1844. Here is his description of Mr. Peach:"But who is that little intelligent-looking man in a faded naval uniform, who is so invariably seen in a particular central seat in this section? That is perhaps one of the most interesting men who attend the associa- 
tion. He is only a private in the mounted guard (preventive service) at an obscure part of the Cornish coast, with four shillings a day, and a wife and seven children, most of whose education he has himself to conduct. He never tastes the luxuries which are so common in the middle ranks of life, and even amongst a large portion of the working classes. He has to mend with his own hands every sort of thing that can wear or break in his house. Yet Charles Peach is a votary of natural history - not a student of the science in books, for he cannot afford books; but he is a diligent investigator by sea and shore, a collector of zoophytes and echinodermata-strange creatures, many of which are as yet hardly known to man. These he collects, preserves, and describes; and every year he comes up to the British Association with a few novelties of this kind, accompanied by illustrative papers and drawings thus, under circumstances the very opposite of such men as Lord Enniskillen, adding, in like manner, to the general stock of knowledge.

"On the present occasion he is unusually elated, for he has made the discovery of a holothuria with twenty tentacula, a species of the echinodermata, which Edward Forbes, in his book on Starfishes, had said was never yet observed in the British seas. It may be of small moment to you, who perhaps know nothing of holothurias, but it is a considerable thing to the fauna of Britain,* and a vast matter to a poor private of the

* About thirty years after the meeting at York, the Neill Prize Gold Medal was presented to Mr. Peach by the Royal Society of Edin- 
Cornwall Mounted Guard. And accordingly he will go home in a few days, full of the glory of his exhibition, and strung anew by the kind notice taken of him by the masters of science, to proceed in similar inquiries, difficult as it may be to prosecute them under such a complication of duties, professional and domestic.

"But he has still another subject of congratulation; for Dr. Carpenter has kindly given him a microscope, wherewith to observe the structure of his favourite animals,_an instrument for which he has sighed for many years in vain. Honest Peach! humble as is thy name and simple thy learning, thou art an honour even to this assemblage of nobles and doctors; nay more, when I consider everything, thou art an honour to human nature itself; for where is the heroism like that of virtuous, intelligent, independent poverty? and such heroism is thine!"

burgh. On that occasion, Professor Geikie said- "Somewhere about twenty species of marine famna, and several genera of sponges, were first made known by him as denizens of British seas. He has considerably augmented our list of uative hydrozoa and polyzoa. The nakedeyed Medusæ owe not a little to his attention, and one genus of them (Staurophora) was first introduced by him to the naturalists of this country. The Echinoderms, too, are under similar obligations to him, for, besides bringing several new species to light, he found the huge Echinus melo of the Mediterrancan on the coast of Cornwall, and supplied the twenty-armed Holothuria nigra to fill up the blank pointed out by Edward Forbes among the British Holothuriæ."-Proceedings of the Royal, Society of Edinburgh, 5th April 1875.

* This is a mistake. The microscope was not given by Dr. Carpenter, but he kindly superintended its fitting up. Mr. Peach obtained the money to purchase it, by superintending and adding to the collections of Natural History at the Polytechnic Institution of Falmouth. 
Some of the gentlemen who attended the meeting at York, and especially Dr. Buckland, in their admiration for the character of Mr. Peach, proposed to do something for his promotion in her Majesty's service. Dr. Buckland wrote to Sir Robert Peel on the subject. The reply was, that there were no openings at the time, but that the application of Dr. Buckland on behalf of Mr.

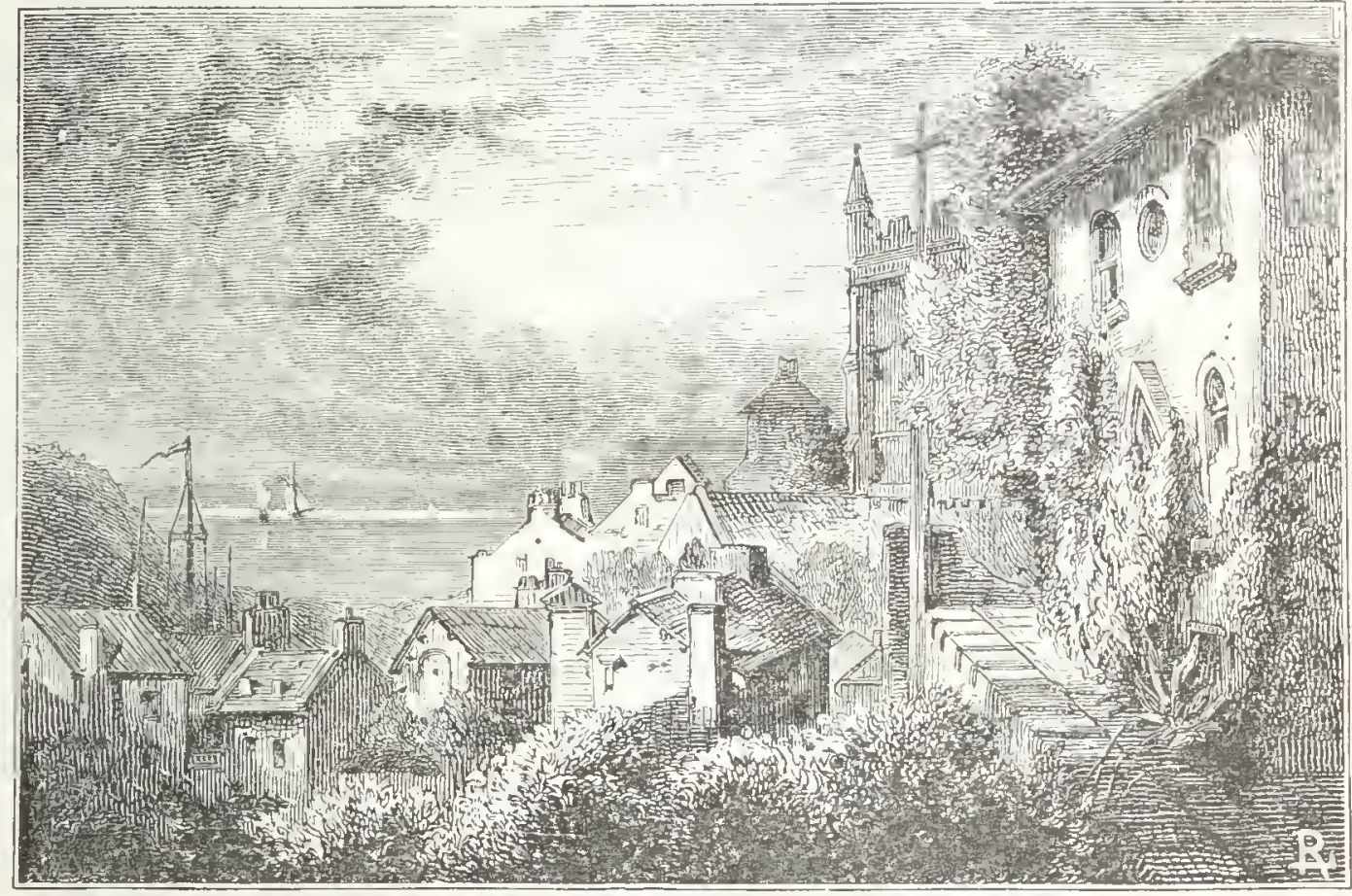

CHARLES PEACH'S HOUSE, FOWEY.

Peach should be kept in mind. At length the promotion came. A position of Landing Waiter was vacant at London, and another at Fowey. Mr. Peach preterred the latter, though the salary was $\mathfrak{E} 50$ less. He desired to remain in his quarters by the sea-coast, to carry on his investigations among the zoophytes, and to further examine the rocks of Cornwall at his leisure. His salary was now $£ 100$ a year; and the advance of pay greatly helped him and his tamily. He removed 
to a pretty house overlooking the river Fowey and the English Channel, and at this house Mr. Tennyson, the Poet Laureate, was a frequent visitor.

While residing at Fowey, Mr. Peach became an honorary member of all the scientific societies in Cornwall. But he was far more than an honorary member. He greatly enriched their collections. He added many organic remains of the Deronian Rocks to the admirable collection of the Royal Geological Society of Cornwall. Indeed, the collection seems to have remained as Mr. Peach left it, some thirty years ago. The President of the Society, at the meeting in 1877 , thus referred to the museum at Penzance:--"Our collection contains Devonian forms from the lower, middle, and upper series, in most of those areas in the counties of Cornwall and Devon, where the rocks are exposed. It must be allowed that it is essential to the credit and future history of the Society that this, of all groups of rocks and associated fossils, should be well, if not perfectly, represented in the museum. The collection, as it now stands, is in the main due to the energy and industry of Mr. Charles Peach, A.L.S., one of our oldest living naturalists, who for many years resided on the south coast of Cornwall, there making a special study of the coast sections, and who extensively collected from them, especially at East and West Looe, Polperro, Polruan, and Forvey. This truly great collection is now displayed in the cases of our Society, and has been but little added to since,-a circumstance especially to be regretted, when we take into consideration the great amount of work and re- 
search that has been done and carried on in foreign countries." *

As constant movement from place to place seems to be the rule of the Revenue Service, Mr. Peach left Fowey in 1849; and this time he was sent to a far-distant place-to Peterhead, in the north-east of Scotland. The removal cost him a great deal of money. His own expenses were paid, but he had to remove his wife and family at his own expense. Yet it was a promotion in the service. He was now Comptroller of Customs. The dignity of the appellation was much greater than the advance of salary, which was only $£ 20$ a year. Still it was a promotion, and it might lead to better fortune.

At Peterhead, as in Norfolk, Devonshire, and Cornwall, Mr. Peach went on with his study of zoology and geology. He added to the list of British fishes, Yarrell's Blenny, Ray's Bream, and the Anchovy,-which had not before been known to inhabit the seas which wash the north-eastern coast of Scotland. He also devoted much attention to the nest-building" habits of certain sea shells and fishes. "At Peterhead," says Professor Geikie, "he made himself intimately acquainted with the family arrangements of that rather fiercelooking little fish, the fifteen-spined stickle-back (Gasterosteus spinachia). In a rocky pool he discovered a colony of them, and learnt how they built their nests and deposited their ova. He watched the hatching and growth of the young until the whole colony, young

* Sixty-Fourth Annual Report of the Royal Geological Society of Cornwall. President's Address, p. xix. Plymouth, 1877. 
and old, took. to the sea. As he used to visit them five or six times a day, the parents grew so familiar that they would swim round and touch his hand, though on the appearance of a stranger they would angrily dash at any stick or incautious finger that was brought near them. The same habit of close and cultivated observation was shown by his study of the maternal instincts of the female lobster in its native haunts." $*$

Mr. Peach's next removal was to Wick,-the greatest fishing town in the North. Though an ardent lover of nature, he never neglected his duty. He was as accurate and quick-sighted in business as in science. He was alike shrewd, wise, and observant in both. He was the model of a Comptroller of Customs, as he was of a true collector and naturalist. His removal to Wick was a promotion. His salary was advanced to $£ 150$ a year, though his duties were to a certain extent enlarged. Part of his work consisted in travelling round the coast of Caithness in search of wrecks, and reporting them to the Board of Trade. This led him to travel to the rocky points of the coast, where the wrecks principally occurred; and he made good use of his spare time by hammering the rocks in search of fossils, and more particularly the fassil plants with which the dark flagstones of the district abounded.

His removal to Wick occurred in 1853. One of the first things that he did was to travel across the county

* Procecdings of the Royal Society of Edinburgh, Session 1874-5, p. 511. 
to pay a visit to Robert Dick at Thurso. While he resided in Cornwall, the name of Robert Dick had been a household word with him. He knew what he had done from Hugh Miller's writings, and he had no doubt that he would find Dick to be a man after his own heart. Nor was he disappointed. When he first called at Dick's shop in Wilson's Lane, on the 19th October 1853, he found that the "maister," as his servant called him, was in the bakehouse. The caller sent in his name, and the baker speedily appeared in the front shop, his shirt sleeves rolled up, and his arms covered with flour.

"I'm Charles Peach of Ready Money Cove in Comwall; and you are Robert Dick of Pudding Goe." That was Mr. Peach's first introduction. "How are ye?" answered Robert Dick, with a firm grasp of the hand; "come into the bakehouse!" That was an honour accorded to few, but in the case of a renowned geologist it was readily granted. Dick went on with his work at the oven mouth, or at the side of the dough, while the two talked together. It was an interesting conversation, which Mr. Peach long remembered. The latter observed on the wall of the bakehouse a full-sized sketch of the Greek boy taking the thorn from his foot, with an Egyptian god on each side,-all accurately done in pencil or charcoal by the Thurso baker.

Mr. Peach called again in the evening, and again found Dick at the oven in the bakehouse. After he had done his evening's work, he had a fire lighted in his parlour, and took his new friend upstairs to see his collection. Mr. Peach was first attracted by the fine 
busts of Sir Walter Scott and Lord Byron, and a large plaster figure of the Venus of Milo, which the apartment contained. Dick then showed his collection of fossils, plants, ferns, and entomological specimens. Mr. Peach, in an entry in his diary, written the same evening, says-" He is a very diffident man, but an enthusiast in natural history pursuits. He is ummarried, and lives most retired. In fact, he is very little known in Thurso. He has a nice collection of Caithness ferns, beetles, and insects. He is deeply interested in botany. His researches in geology have been great, especially in the Old Red Sandstone; and some of his specimens have added new links to the history of these ancient rocks."

Mr. Peach soon repeated his visit. He called again at the beginning of the following May, and again found Dick very busy in his bakehouse. The fire was not again lighted in the parlour. Peach was now regarded as a friend. All the subsequent interviews between the two occurred at the mouth of the oven, or in the kitchen, or in the fields, or among the rocks. All ceremony and formality were laid aside; and although they had many differences of opinion and stout debates, these were, like lovers' quarrels, soon made up.

Mr. Peach entered the following passage in his diary, descriptive of his second visit to Dick:- "2d May 1854. Rose early; called upon Mr. Dick; found him at his oven, and very busy; had a nice chat with him. . . . In the evening I saw him in his bedroom. What an industrious man he is. He is through nineteen volumes of plants, and hopes soon to finish his herbarium. He 
has heaps upon heaps of specimens, and appears to thoroughly understand his subject. After two hours' chat I left him to go to his bed, to which, if possible, he retires at 9 P.M., to rise again between 3 and 4 A.M. I have often been up and with him at that time, not willing to lose time when I had an opportunity of enjoying his society. His conversation was too precious to lose."

During the ensuing summer, when the grasses and plants were in bloom, the two took a long walk up the Thurso river. Dick pointed out to his friend the habitat of the Holy Grass (Hierochloë borealis), which he had long known; and also what was then called Drummond's Horsetail (Equisetum pratense). Dick also pointed out the Baltic rush (Juncus balticus), which Mr. Peach had never before seen. Mr. Peach says of this walk, that "Dick's cheerful manner, his sparkling wit, and frolicsome playfulness, added to the other beauties of the excursion, made it a treat indeed."

"My next visit to Thurso," says Mr. Peach, " occurred in connection with a wreck, happily unattended with loss of life. On this occasion, our first difference broke out. The Old Red Sandstone period was said to be one of seaweeds and cartilaginous fish. That I felt to be unstable, from specimens which I had picked up in my spare minutes snatched from duty. We both defended our views. He was strenuous in his defence of Hugh Miller's and his own opinions, and although I felt a sad heretic, I warmly, but I hope modestly, suggested that I might be right. Time has since proved that I was so, and dear Dick set to working out the problem for him- 
self as usual, and at last he came to the same conclusion that I had done. I have just found a note in reply to one of mine. After saying that he is ready to be my pupil in seaweeds, zoophytes, and in every other department of natural history, he adds, and 'even in fossil wood'*_a jocular allusion to our discussion on this point."

Mr. Peach, in a recent letter, referring to the many happy hours and tough battles fought in Dick's bakehouse, says that old Annie, the housekeeper, would sometimes interfere, and say, "Eh, maister, ye're awfu' hard wi' Mr. Peach; he'll never come back again after sic rough usage." But Peach came back as before. The lover's' quarrels soon healed, and they were more affectionate than ever. "I had the advantage," says Mr. Peach, "in having read all that Hugh Miller had done, and also many of Dick's letters on the same subject. Besides, I had had lots of experience in Devonian and Old Red rocks in more places than Scotland. I had also a mode of my own for collecting. I got all the weathered and detached portions of fishes and plants, studied them, and fitted them into more perfect specimens. But Dick did much good service. He was fortunately in time to

* Hugh Miller, in his Testimony of the Rocks, refers to this fossil wood as a "curious nondescript vegetable creation." He adds:- "I liave not hitherto succeded in finding for myself specimens of this olganism, which has been llamed provisionally by Dr. Fleming Stroma obscura; but it seems not improbable that certain (supposed) fragments of wood, detected by Mrr. Charles Pcach in the Caithness flagstones, but which do not exhibit the woody structure, may have belonged to it." 
reap the harvest. I only got his gleanings. But I found for myself new fields of unworked rocks in Sutherlandshire, and got new fishes there, and also new ones in the old fields that Dick had so long been working in. I was very fortunate. My duties led me so far about, and gave me many opportunities that I should not otherwise have had; whereas Dick was confined to the neighbourhood of his bakehouse in Thurso. All this I took advantage of, after duty had been done. By rising early in the morning and working until late at night; by often giving up my meal times, and satisfying myself with a crust of bread and butter, and at night with a Highland tea and something to eat, I fortunately contrived to fill up my leisure hours with a good deal of useful work."

The principal new field to which Mr. Peach refers, was the limestone of Durness in Sutherland. The spot was too far from Caithness to enable. Dick to investigate it. But it was in the Comptroller's way. He went to Durness to visit a wrecked ship, and he did not neglect his opportunity. He was the first to find fossils in the limestones of Durness. Obscure organic remains had before been detected by Macculloch in the quartz rocks of Sutherland; but they had gradually passed out of mind, and their organic nature was stoutly denied even by such geologists as Sedgwick and Murchison. Mr. Peach, however, brought to light, in 1854, a good series of shells and corals, which demonstrated the limestones containing them to lie on the same geological horizon as some part of the great Lower Silurian formations of other regions.*

* When Sir Roderick Murchison heard of this discovery, he wrote 
The discovery remained without solution for some years, the principal geologists still doubting its reality. But about five years after, Sir Roderick Murchison again visited the spot, and the discovery was confirmed. Professor Judd, of the Royal School of Mines, Jermyn Street, London, said in the Geological Society's Quarterly Joumal that "Charles Peach's discovery in 1854 of Silurian fossils at Durness, Sutherland, has already borne the most important fruit; and, in the hands of Murchison, Ramsay, Geikie. Harkness, and Jamieson, has afforded the necessary clue for determining the age of the great primary masses of the Highlands of Scotland."

We have thus described the origin of the friendship between Charles Peach and Robert Dick. It strengthened as it grew. Charles Peach shared all Dick's enthusiasm, and bore a warm and constant friendship for the solitary student. They communicated to each other, as all true labourers in science do, the results of their respective discoveries. They kept up a regular correspondence, and many of their communications with each other will be found referred to in the following pages.

to his friend Professor Sedgwiek:- "You have no doubt heard of the diseoveries of fossils in the Durness limestone of Sutherland by Peach. He has corresponded with me on the point, and has sent me some of the fossils. I have had them polished. The forms, rude and ill-preserved as they are, look nore like Clymeniæ and Goniatites than anything else, with eorals; and, if so, the caleareous masses which I saw from Assynt to Durness, interstratified in the quartz roek, aro high in the Devonian. I would like to hear what you say to this éclaircissement I I see great diffieulty in understanding it."-Professor Geikie's Life of Sir Roderick I. Murchison, vol. ii. p. 195. 


\section{CHAPTER XVII.}

\section{ROBERT DICK AND CHARLES PEACH}

A succession of visits from Peach to Dick, and a long correspondence between them, followed their first introduction. Peach travelled a great deal, especially during the shipwrecking season; and when in the neighbourhood of Thurso it was his invariable practice to call upon his friend Dick. They communicated to each other all that they had found since their last meeting, and they often sent parcels of shells and fossils by the carrier's cart, with numerous communications, to ask each other's opinion about their special findings.

Shortiy after Peach's first visit to Thurso, he found a specimen of a new fossil fish which he thought allied to the Dipterus. It was a bony fish. He consulted Dick on the subject. Dick thought it very unusual; and "from the resemblance (he said) which it bears to the vertebral column of the Coccosteus, fragments of which are commonly attached to its buckler, I should, for my part, have no hesitation in pronouncing it what you take it to be.* Cartilage becomes petrified, and in some formations cartilaginous fish are found. But your speci-

* For description of this bony fish see Decade X. Geological Survey, Parts iv. v. p. 51. 
meu shows as decidedly bony a structure as Coccosteus. Your specimen is altogether new to me. I will take good care of the fossil. . . I I am in a tremendous hurry of business to-day, but feel your kindness very much. ... Since you saw me here I have walked to Morven top and back again to Thurso with little inconvenience. I have since been at Scrabster hills, and intend being at Duncansby Head very soon."

Dick and Peach also interchanged shells with each other, though Dick said in one of his letters- "I do not think that you require any information from me on matters pertaining to this or any other study or research. You are a bred veteran, and I am but a greenhorn." Still, Dick would not give way on any point on which he thought that he was right and Peach wrong. He insisted that he was entitled to have his say, especially where his own eyes were concerned. He did not believe so much in books or in theories, but he believed in facts.

In one of Peach's enthusiastic letters he expresses the hope that Dick is "revelling in the midst of the beauties he has collected." To this Dick replies, "I dimna ken. . . Y You perhaps know the story of the gentleman who returned from India with a black servant. One frosty morning the master went a-shooting, and took the dark Oriental to beat the bushes. He was rendered powerless by the cold. The master impatiently demanded why he did not cry 'Hush, cock, hush.' ' Ah, massa,' he tremulously replied, 'me wish hush cock had never been born.' And so, Massa Peach, sometimes I wish beauties had never been born. Not that there is 
too much loveliness in Nature; but that the hunting for objects of interest squeezes me so very confoundedly that the wonder perhaps is, not that I do so little, but rather that I manage to beat the bushes at all.

"The monk of Cambray !-Yes, I think 'twas he, The inonk of Cambray was a wonderful man!

He turned his face to the northwards, And, mutt'ring a prayer with Amen! he began Reading backwards instead of forwards!

"Exactly so! And dull disciples in the school of Stones too much resemble him. Whether from the effect or defect of early training, when too much left to themselves, they soon fall back to their first ideas, and monkishly read backwards. Our friend Hugh Miller knew that I never fell in love with his peculiar views on the order of creation; and how he did me the honour of enrolling me among the geological gods remains a mystery to this day. I suspect that, just before pushing me in, he had been consulting the Apostle Paul, who says - "Him that is weak in the faith receive ye ;' but then he adds, 'Not to doubtful disputations.' Ah! there's the rub! I am a sad mule. What then? Every one according to his gift. Conviction must precede conversion.

"All that lived during the deposition of the Old Red Sandstone has not been preserved. What has been preserved has not been found. What has been found is understood very imperfectly. No geologist has said that all that lived during the deposition of the Silurian, the Old Red, Carboniferous, and other formations, has been 
preserved. They rather allow that not a tithe, not a fractional part, has been petrified and preserved. And how do they know that this earth had not once a habitable surface capable of accommodating the whole of them? all that has become extinct, and all that still survives? . . . I have not the least doubt that had Sir Charles (Lyell), Sir Roderick (Murchison), Agassiz, or Hugh Miller, taken a fancy to work out the notion, they might have given us a habitable surface capable of accommodating all that lives with all that is extinct, and thus saved us the necessity of swallowing that, to me at least, unpalatable thing, a patchwork creation-a system of odds and ends, of clippings and parings. I cannot believe that this earth ever saw a creation but one. Much has become extinct I allow, but much is supposed to be extinct which is not extinct.

"I grant that chronology is corrupt. I. grant that the earth is much older than was at one time thought; and that our habitable surface was not made in a day, or in a week, or by a word; but I cannot accept the order of creation that geologists have carved out for me. The arguments of geologists, like disturbed strata, have a peculiar dip, and a strike, by which you can easily distinguish the school of the reasoner.

"And what means all this palaver? I am simply provoked by the old monkish trick of reading backwards instead of forwards. This is a land of liberty, and I avail myself of the privilege of resting and waiting for further light."

Such were Dick's views at the beginning of 1854 . 
About the same time, he wrote to Hugh Miller, "Do you know, I am often accused of bearing an ill-will to geologists! When I think them at fault, and am asked to speak, I merely speak what I think to be the truth. Mr. John Miller here has got Murchison's thirtyshilling book, and handed it to me to look at. Well, unfortunate fellow that I am, I saw that Sir Roderick was entirely wrong in saying that Cyclas was confined to the uppermost beds of the Old Red. I told him so, and he, as usual, thought that I was doing injury, and what not, to geology! Poof! poof! In what respect was I a gainer or Murchison a loser? Instead of being angry, you geologists should be pleased, as it shows that we pay attention to what you say."

$\mathrm{Mr}$. Peach went to the meeting of the British Association at Liverpool in September 1854; and there he read his paper as usual. On this occasion he recorded his observations on "The Remains of Sand Plants and Shells in the Old Red Sandstone of Caithness." On his return to Wick, Dick wrote to him, and asked, "What did you say about the fossil wood? Tell me also about the shells." It may be mentioned that there was a long discussion between the two geologists about fossil wood. Dick was of opinion that the stuff which Peach had found in Caithness was "concretionary bituminous matter, and not organic." "But I am anxious," he says, " that my opinion about the matter should not retard the progress of discovery. I may be wrong, as I have been before. Professor Forbes described the fossil wood to be 'chert,' and 'masses without structure.' If I am 
wrong," said Dick, "men of mark have been wrong · men of repute, though I am of none."

In the meantime, Peach sent Dick specimens of fossils and plants. One of these was found near Wick, the Tectura testudinalis - a mollusc. Another was a Cornish heath - the Erica vagans. Of the latter Dick said, "I am very much obliged to you for it; and as my plants and I do not mean to separate while life lasts, I shall have a memorial of you, and I hope a proper sense of your kindness, each time that I examine it. . . ' 'Tis a pity I have no other rarity, but I will give you a few grasses - a little brownish, and not so good as your last one."

Dick again refers to his botanical collection. "Every moment of my spare time is devoted to the labelling of my papers, and attaching dried plants to them. Thanks be praised, it is nearly over, and the roughest work is done. All the plants are gummed down, and the craving for a completion stirs me anew. How they are to come is a myster'y, but then hope never fails me. . . Y Your first favour of a mistletoe is in its appointed place, and the present addition you have sent is equally welcome. You may rely upon it, you bestow the specimen on one whose very life is bound up with those things; and I can in all sincerity say :

"For them I panted, them I priz'd

For them I've gladly sacrificed

Whate'er I lov'd before;

And shall I see them sacrificed?

*Na, na, man. Many thousand thanks to you. My 
friends are few, and I get on slowly. However, that English gentleman spoke, not long ago, very kindly to me; and if all goes well with him and me for a short time, 'I'll cock my bonnet fu' braw.' He is a thorough botanist."

The English gentleman referred to was Mr. W. L. Notcutt, then residing at Fakenham, Norfolk. He had asked Dick to send him a collection of the Old Red fossils of Caithness; offering his botanical services in return. Dick cheerfully complied with his request, and Mr. Notcutt acknowledges "most cordially his noble suite of fossil fish from the Old Red Sandstone." "There are no fossils I more wished for," he says, "than some specimens from your ancient strata, and your kindness has indeed furnished me with a magnificent collection. .. . I fancy your creed in natural history is somewhat akin to my own. I make very free in asking help from brother naturalists, and I am never better pleased than to be made quite as free use of in return. Indeed, I think the very character of our pursuits almost claims the free interchange of such help; for, unless one is possessed of an independent property, the amount of travelling necessary for the examination of the productions or geological deposits of distant parts of our land is otherwise an impossibility."

Mr. Notcutt accordingly added largely to Robert Dick's botanical collection. He sent him additions from year to year, until he had almost finally completed his collection; Dick, at the same time, furnishing him with examples of the grasses and plants growing in the county of Caithness. 
Robert Dick received numerous letters from men of distinction, requesting specimens of the Holy Grass which he had discovered on the banks of the river Thurso. Professor Balfour wrote to him in 1854, requesting roots of the plant for the Botanical Garden at Edinburgh. Dr. Allman, then professor of Natural History at Edinburgh, and now president of the Linnean Society, requested specimens of the fossil fish for the University Museum. Letters flowed in from Perth, from Aberdeen, from Glasgow, from various places in England and Ireland, requesting specimens of the Holy Grass, of shells, and of fossil remains. Among his correspondents we find the names of the Rer. Mr. Brodie, of the Vicarage, Rowington, near Warwick; Mr. Backhouse, of York; and Professor Babington, of Cambridge. Many of these were made known to Dick through his friend Charles Peach.

The correspondence with Mr. Peach continues: "I am sold," says Dick, "body and soul, to dried plants, not fossil ones; - no breaking of stones or anything else for me, but the drudge of self-denying determination. . . . Who was it that wished he was a tailor, for then he might sometimes get a holiday? Ay, Mr. Peach, plants are plants, and stones are stones indeed, to those who gape and gasp to get a mouthful of fresh air. But man was born to struggle and to endure."

Unfortunately, Dick's health began to fail. He complained of a rasping cough, and of rheumatism. Though a strong-looking man, and in the prime of life (for he was not yet fifty), he complains of pain-daily 
pain. He says to his friend Peach that he is "suffering the punishment of over-fatigue and confinement to the house." He had no assistant in his daily labour-no journeyman, no apprentice. All his work was done by himself. And yet he continued his walks. "Like all confined animals," he said, "when snuffing the caller air, I become quite uproarious. . A walk of twenty-six miles is such a very fine thing."

But it is an awful thing in the North to take a walk on a Sunday. The Thurso folks saw him going out and coming in on that day, and they were very much shocked. What could come of such a person? They began to belabour him with tracts. These accumulated on his hands so much, that he went to the oven one day, drew the fire to the front of the grate, put in the bundle of tracts, and pushed the burning coals back, thus consuming them to ashes.

A few years later, when Dr. Macleod raised such a stir in the North by his observations as to the Judaical observance of the Sabbath by his countrymen, Robert Dick observed to his brother-in-law:- "I have got the newspaper containing the uproar about Dr. Macleod, and am much amused at what their reverences said. They would, if they could, shut out the light. 'Donald, man, Donald! what is it that ye'll aye be shutting out ta light?' 'If ta tail pe brak, ye'll find that! Very good; and all the noise, I fancy, is for fear that 'the tail pe brak." "*

* The allusion is to an anecdote of two expatriated Highlandmen in Canada, who went out to hunt for wild pigs. They found a litter in 
One Sunday morning, when wearied out with his week's work, he went out to take a walk. He described it in a letter to his friend Peach, written in the month of July. He begins with the quotation:-

"God blames not him who toils six days in seven, Where smoke and dust bedim the golden day, If he delight beneath the dome of heaven

To see the clonds and hear the winds at play.'

"To-day," he said, "the wind blew hard, and as I had been wearied with heat, sweat, and confinement during the week, it struck me that a walk of about eight miles up the country would do me good in every way.

"Well, I had got about eight miles out. Some beautiful tufts of Erica Tetralix grew temptingly a few paces off, along the high road. So, without a moment's hesitation, I stepped aside among them, and, stooping down, began pulling at them admiringly. From my reverie of delight, amidst beauties blushing crimson, I was suddenly startled by a rough voice accosting me in Gaelic. I looked round, and saw one of the ugliestfaced Highlanders that ever 'cam doon' staring wildly at me. 'A blowy day,' said I. 'Ach, ach,' said he. A brief silence ensued. 'Why are ye no at sermon?'

a eavern with a very small entrance. The mother was out. One Highlandman went in to slay the pigs; the other kept watch ontside. The mother-pig, hcaring the screams of her family, carne up suddenly and rushed into the hole. The Highlandman outside took fast hold of the animal's tail, and held hard, occasionally using his dirk. Hence the noise from the inside: "Donald, man, Donald! what is it that ye'll aye be shutting out ta light?" and the answer from the outside was, "If ta tail pe brak, ye'll find that." 
he growled. 'Why are ye no at sermon yoursel ?' I replied. 'Eh ?' said he; 'oo, ye see I maun mind the beasts.' 'Well,' said I, 'we are very much alike. You mind your beasts, and I mind this (holding up a piece of the beautiful plant I had plucked). We have both our reasons for what we are about.' 'Man!' he said fiercely, 'ye're nae better than a beast, tae be looking. for grass on the Sawbath. The cattle there want reason, which maybe you have.' 'Stop, my good fellow,' said I; 'the cattle look at the plants without seeing the least beauty in them; they pick out the grass here and there to fill their bellies; but I look at them for the improvement of my mind.' 'Ach!' he grunted; and then he roared, 'It's a sad thing for a man who has got one wife already, to go a - after another.' At this coarse outburst I laughed loudly; and after telling him that I had got no wife at all, I suddenly walked away and left the man with his beasts. I wonder what this blind zealot would have done to me if he had the power. The less we know, the more intolerant and tyrannical we become. All the religious persecutions that we read of are merely the result of ignorance, and of the cruelty that comes of ignorance. I wonder whether that man ever thinks of the words the Master he pretends to serve once said to His disciples_-'Consider the lilies of the field, how they grow; they toil not, neither do they spin; and yet I say unto you, that even Solomon in all his glory was not arrayed like one of these."”

Amongst the numerous scientific men who sought the acquaintance of Dick was the late Sir Roderick 
Murchison. He was appointed Director-General of the Geological Survey and of the School of Mines in 1855, and having been informed of the remarkable discoveries made by Mr. Peach in the Durness limestone, he proposed to make a journey in the north-west of Scotland in the course of the same year. He started in August, accompanied by Professor Nicol. They went by Inverness, to Applecross, Gairloch, and Assynt. They went northward to Durness and Tongue. It does not appear that Sir Roderick made any new discoveries on this occasion; field-geology was in the meantime at fault. Professor Geikie, in his Life of Murchison, says that "so far as respected any new light on the geology of the north-west of Scotland, his excursion to Assynt left matters very much as they were."*

When at Tongue, Sir Roderick and Professor Nicol drove across the country by the north coast to Thurso. They were not then personally acquainted with Robert Dick, though they had often heard of him by name. Professor Nicol first sought him out, and then he took Sir Roderick to his shop in Wilson's Lane. The latter wished for some information from Dick as to the localities where he had found certain old Red fossils. Dick, however, was very busy with his batch at the time; he could not leave his bread to burn in the oven, in order to give the necessary information. The travellers were also in a hurry, as Sir Roderick had many other places to visit before the next meeting of the British Association, which was to be held at Glasgow in the beginning of September. 
Sir Roderick, however, did not forget the Thurso baker-geologist and botanist. In May 1857 he wrote to him from the Museum of Practical Geology in Jermyn Street as follows:- "Dear Sir-Aware of the talent you have evinced in collecting rare and good specimens of the fossil fishes of the Caithness flags, and finding that this establishment is very poor in such remains, I venture

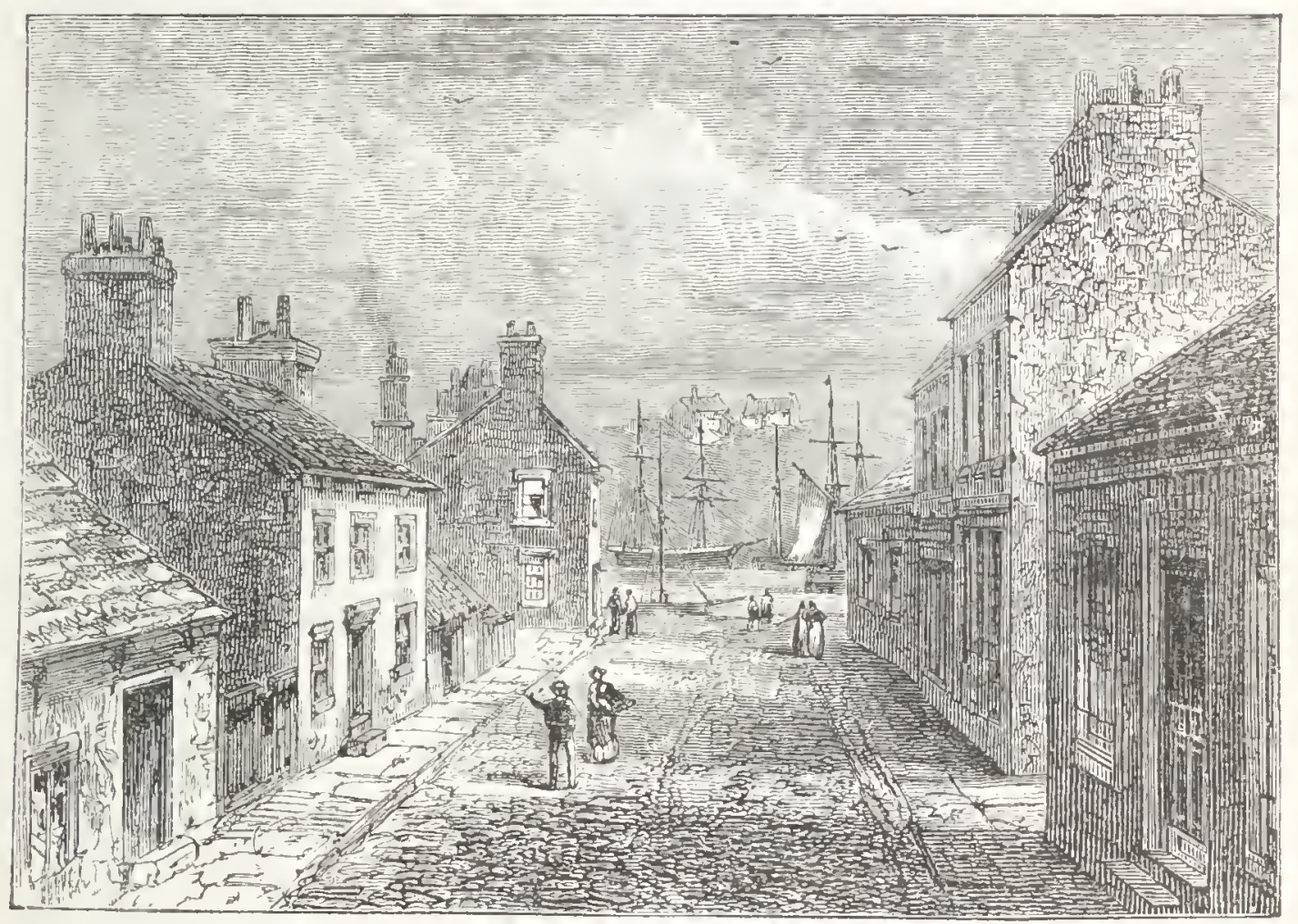

DICI', HOUSE, WILSON'S LANE.

to ask you to tare some steps to supply us with a few really good things in the ichthyic line. All cost of extraction, as well as the full value of the fossils, would be paid thankfully to the finders. Pray excuse the freedom I use. I have no other means of endeavouring to secure this desirable object."

Robert Dick acceded to the baronet's request. He did not sell any of his fossils, but he sent the donation 
of "a very fine specimen of Asterolepis," for which their Lordships of the Committee of Privy Council of Education sent Mr. Dick their best acknowledgments.

Sir Roderick Murchison was much more fortunate in finding Dick at liberty on his next visit to Thurso. Besides, he had Charles Peach with him, who soon made everything smooth between the baronet and the baker. They were both introduced to the bakehouse. It was only Dick's intimate friends who were introduced to that sanctum sanctorum. Dick was still in his working clothes. A conversation took place about the dip of certain rocks in Caithness. Sir Roderick complained of the want of any sufficient map of the county. Here Dick could chime in with him. In fact, he had wandered over the whole length and breadth of the county, and found that the existing maps were mere "bosh." "But if you will permit me," he said, "I will endeavour to show you a map of Caithness." "By all means," said the baronet.

Taking up a few handfuls of flour, and spreading it out on the baking board, Dick proceeded to mould a model in relief of the geological structure of Caithness. He showed all the principal features of the county-the hills and dales, the rocks and cliffs, the dislocations and fractures, the watersheds and the drainage, and, in fact, an outline of the entire geography of the county. To quote the words of Sir Roderick Murchison, "Mr. Robert Dick directed my notice to the presence of numerous powerful fractures and dislocations in the flagstones ranging over Caithness, and which, to the 
superficial observer, seem to lie simply in undulations. But to whatever extent these dislocations have occurred, they never can be accurately defined until a correct map of the county be executed, it being a melancholy fact, that though easily capable of examination owing to the slight elevation of the greater part of the county, Caithness is probably the worst mapped county in Scotland."*

Mr. Peach has also a pleasant recollection of the interview. He says: "I felt it to be a great privilege indeed to be present at the meeting of the baronet and Dick in the bakehouse. It was a treat to me to see the hills and dales, the rocks and cliffs, made up with flour, and a likeness of Caithness moulded in relief by his nimble fingers. He seemed to be familiar with every foot of the county, every hill and dale, every movement and flexure, every fracture and dislocation, and the readiness and ease with which he communicated the information greatly pleased and surprised the renowned geologist; and when he left the place he expressed his delight and astonishment at the amount of information he had received from the wonderful, though comparatively unknown, baker of Thurso."

The conference between Sir Roderick Murchison and Dick lasted so long, that Peach says "he was so much overcome by sleep, that he had a long nap while they talked together." For Dick took the baronet up to his museum, and showed him his collection of plants. Sir Roderick was as much surprised at his knowledge of

* Sir Roderick Murchison's Situria. Fourth edition, p. 269. 
botany as of geology. He found that Dick had almost exhausted the plants of Caithness, and that he was engaged in making up a complete Herbarium, principally by exchanging plants with other botanical collectors.

When the two geologists left Dick's shop, they went to the flag yards over the river, for the purpose of obtaining pieces of the Banniskirk flags for analysing. " $\mathrm{W}$ e

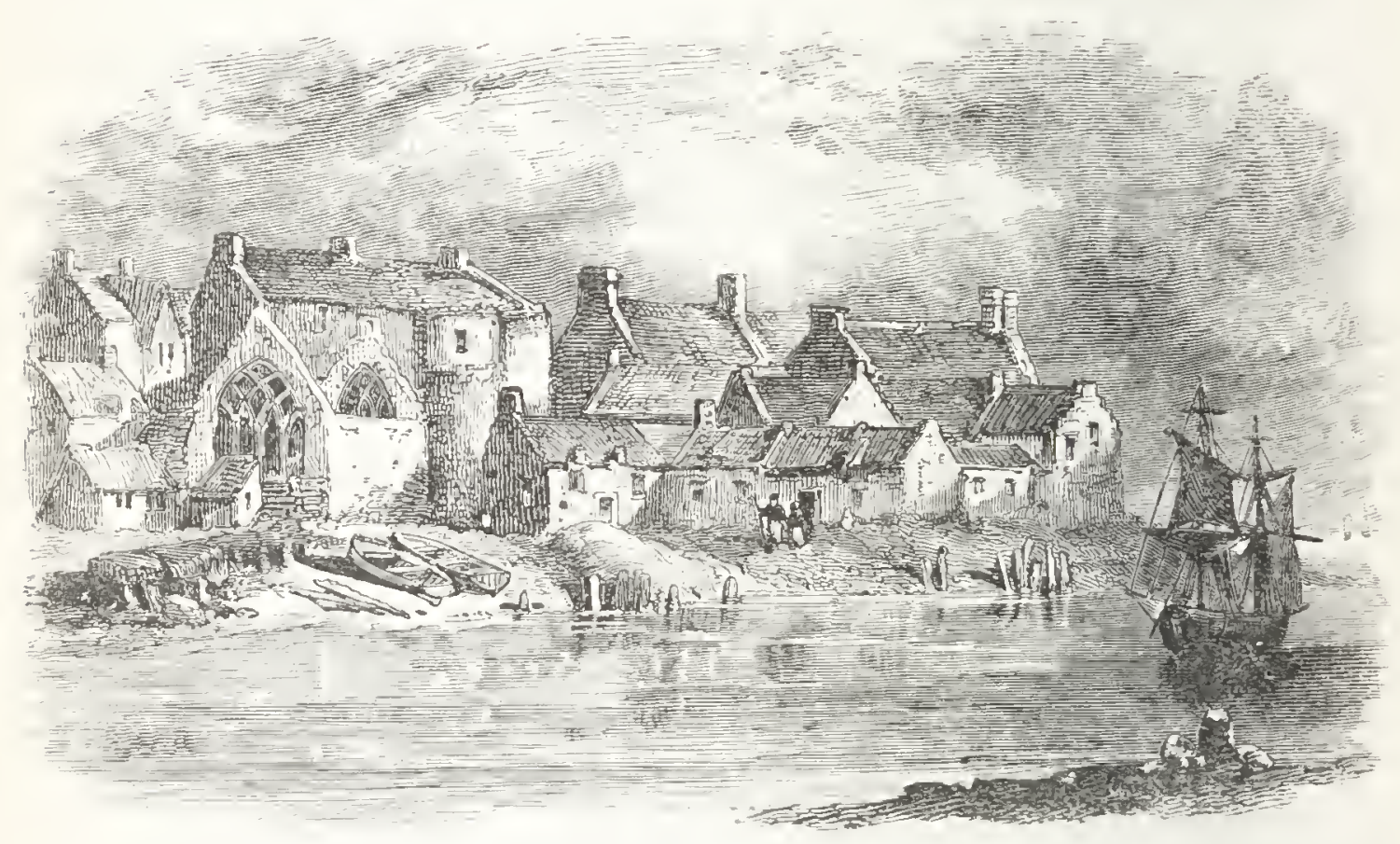

THURSO RIVER: THE OLD CHURCH.

got a boat," says Peach, "passed over the harbour, looked at the Old Church, and felt much disgusted with the Thurso people for leaving it roofless and allowing it to go to decay."

Before he left Thurso Sir Roderick addressed Dick in the following letter:-**

"My dear Mr. Dick-I cannot leave Thurso for the Ultima Thule without thanking you sincerely for the

$$
\text { * 31st July } 1858 .
$$


information I have received from you respecting the structure and succession of the Caithness deposits, and for your very agreeable conversation, which was so instructive as to the physical geology of these parts of Scotland. Pray do not forget the old geologist who wrote upon Banniskirk fishes thirty-two years ago, and who much desires to make a decent show of them in the great National Museum of the Survey; and in return I promise you all the rarer British plants, which are to be had by the zealous endeavours of-Yours most faithfully,

Roderick I. Murchison."

On the following day, Sir Roderick and Mr. Peach left Thurso for Stromness in the Orkneys, on the other side of the Pentland Firth. They went to Kirkwall, passing on their way the Standing Stones of Stennis, the Orkney Stonehenge. On their way north, they visited Sumburgh Head, and saw the Old Red Sandstone of Caithness prolonged into the southern limb of the Shetland Islands. Then to the northernmost island of the group; and finally the two geologists were dropped by the steamer "Pharos," on its way south, on the bleak headland of Cape Wrath. They proceeded to visit the Durness limestone, where all that Peach had already discovered was confirmed by the personal observation of Sir Roderick. It was not until the end of September that Mr. Peach reached Wick.

In the meantime, Sir Roderick proceeded to Leeds, where the next annual meeting of the British Association was to be held. There he laid before the geological 
section "The Results of his Researches among the older rocks of the Scottish Highlands." He did full justice to Mr. Peach's discovery of organic remains of the Lower Silurian age in the crystalline limestone of Sutherland; similar to those which occur in the Lower Silurian rocks of North America. Sir Roderick also said in his paper, that as regarded the ichthyolitic flagstones of Caithness, "he had made various interesting additions to his former knowledge, particularly as derived from the researches of Mr. Robert Dick of Thurso."**

But Sir Roderick made further mention of Robert Dick at the public meeting held in the Leeds Town Hall on the 29th of September 1858. In fact, his eulogium of Dick constituted the principal part of his address. We have already given part of it in the preface to this book, and need not here repeat it. Sir Roderick concluded his speech by saying that he had referred to the facts relating to the marvellous knowledge acquired by this humble working baker of Thurso, "in order that the audience might deduce a practical application."

Mr. Peach immediately sent to his friend at Thurso the newspaper in which the report of Sir Roderick Murchison's speech appeared, and he also congratulated Dick upon the cordial manner in which the baronet had referred to his scientific knowledge. Dick, as we shall afterwards find, did not think so much of the speech as Peach did ; but, after about fifteen minutes' deliberation, he scribbled off the following stanzas, and sent them to Charles Peach as his answer. Peach sent the verses to

\footnotetext{
* See Leeds Meeting of the British Association, 1858.
} 
the Wick newspaper, where it was printed under the title of the "Song of a Geologist." *

Hammers an' chisels an' a', Chisels an' fossils an' a ;

Sir Rory's the boy, o' the right sort o' stuff, Hurrah! for the lammers sae braw.

It's good to be breaking a stone, The work now is lucky an' liraw ;

It's grand to be finding a bone--

A fish-bone the grandest of a'.

Hammers an' chisels an' a', Chisels an' fossils an' a ;

Resurrection's our trade ; by raising the dond We've grandeur an' honour au' a'.

May labour be crown'd wi' successMay prudence promulgate the storyMay scoffers grow every day less, Till the rocks are a mountain o' glory.

Hammers an' chisels an' a', Chisels an' fossils an' a';

The deeper we go, the more we shall know Of the past an' the recent an' $a$ '.

Here's freedom to dig and to learn-

Here's freedom to think an' to speak;

There's mane ever grumibled to look at a stone, But creatures baith stupid an' weak.

Hammers an' chisels an' a', Chisels an' fossils an' a';

In spite of the devil we'll dig as we're ableHurrah ! for the hammers sae braw.

Amigaloid.

* It is said that these verses so pleased Sir Roderick Murchison $13 *$ 
Dick was amazed to find liimself in print for the first time. In writing to his friend $\mathrm{Mr}$. John Miller, then residing in London, he said :- "If there be Amygdaloid among the fossiliferous rocks of Thurso, or in your native county, your humble servant has hitherto failed to detect it. Charles Peach has a wonderful talent that way, and I remember his bringing me some pieces of supposed trap from the neighbourhood of Wick. But when I sent him these scribblings he thought for certain that he had found an eruptive rock at last. He clapped them into the paper and stuck Amygdaloid at the end. Charlie had found trap again. If the matter had depended upon me, the printers in Wick would have been saved the trouble of setting the verses up in print."

To Peach he wrote:- "The rhyme was merely meant to make you laugh, and, that purpose served, to burn it. Time was when I used to scribble songs by the dozen, though I dare say no one would give a bawbee for a bagful of them.... I never was free enough of care and trouble to cultivate the gift. . . . Sentimental folk want fine feeling and fine language, and I canna be fashed. And you laughed, did you? So much laughter, so much life enjoyed. You are very dowie, you say. Well, Charles, if you gain by that, you'll lose by nothing.

So, you sit by the fireplace, And moping away,

and the eminent band of geologists belonging to the "Red Lion Club," that they were inserted in their records and sung at their anmul meetings. - John o' Groat's Journal. 
To field or to sea-side

Want courage to stray.

When fernies are withered,

And field flowers are gone,

Oh! who would go hunting

Starfishes alone?

After that, Dick confesses that he himself feels very dowie-he says he is very unwell, still feverish, with cough, cough, cough! Nevertheless he appends another bit of rhyme, to make Charlie laugh again!

Oh, gin ye was a fossil fish

Long petrified in Auld Red Stanes, An' I a wanderin' found the rock

That held the remmant of yeer banes!

How I would try to dig ye out, And send ye up to Lon'on fair,

Weel pack't and sealed, ye needna doubt,

To rest at Ror'y's * evermair!

Oh, gin ye were an Alpine plant

That grew upon the mountains high, An' I a wanderin' found the plant

The little mossie burnie by !

How I would joy, if ye did 'scape

The wintry winds and storms severe-

I'd pu' and put ye in my cap,

An' dry ye, for a thousand year!

When Sir Roderick Murchison next visited Sutherland, in August 1859, he was unable to call upon Robert Dick; but he sent him the following letter :- 
"My dear Mr. Dick-I send you by this mail a copy of my memoir on 'The Geological Structure of the North of Scotland.' It is a Great Reform Bill which I am endeavouring to pass; and it is hard to induce old mineralogical and bit-by-bit geologists to enter into my views. But if the grand superposition of strata be not set aside, nothing can be so clear (nothing at least that I have ever seen in any county) as the A B C D of the great steps by which the geologist ascends, in proceeding from the west to the east coast of the north of Scotland.

"I deeply regret not to be able in my conscience to go and shake hands with you this summer. The fact is, that the general succession in Caithness, under the administration of Peach and yourself, is quite secure. I must therefore look to tracts never explored by me; and being satisfied myself that the statements printed in my memoir are substantially correct, I wish to test them by exploring the tract between Melvich and Helmsdale, which I have never yet visited.

"The workers had very nearly completed all your Herbarium before I left London, and you will have it soon. Professor Ramsay is with me, and is delighted with the clearness of the order of succession. He is to sing 'Hammers an' Chisels an' a' at our next amniversary dinner.-Yours very faithfully,

"Roderick I. Murchison."

The remainder of the herbarium promised by Sir Roderick reached Thurso. shortly after the date of his 
letter. Dick again exercised his rhyming faculties on his friend Peach. "As for mysel," he said, "should anybody speer for me at Aberdeen, you may say that I am quite merry, singing like a cricket over those dried plants that Sir Roderick has sent me. Listen a minute:

$\mathrm{O}$, will ye gang oot owre the moor?

$\mathrm{O}$, will ye gang wi' me, Rory?

To while awa' a weary hour ;

I'm sure I'd gang wi' ye, Rory.

We'll wander 'mang the heather knowes,

Their bonnie bells to pu', Rory!

An' where the purple fox-glove grows,

His stately grace to view, Rory!

$\mathrm{O}$, will ye gang oot owre the moor, etc.

How lightly would I clim' the hills

To gather thyme wi' ye, Rory!

And seek the wild flowers by the rills,

As blithely as a bee, Rory!

$\mathrm{O}$, will ye gang oot owre the moor, etc.

See what it is to get a good crop of hay! I'm just as happy as a beggar; and, like Tam o' Shanter, 'owre a' the ills o' life victorious!" " 


\section{CHAPTER XVIII.}

\section{LION-HUNTERS-FERNS AND MOSSES.}

After Sir Roderick Murchison had made his speech at Leeds, Robert Dick's name was carried far and wide on the wings of the press. He was spoken of as one of the most extraordinary instances of the pursuit of knowledge under difficulties. Even the Thurso people began to look upon him in a different light. "They had long regarded him as partially insane," said the editor of a Wick newspaper. "But as time rolled on opinions gradually changed. By and by it began to be whispered that men of great influence were visiting the mad Thurso baker; and when it was found that at the meetings of the British Association he was named as one of the highest authorities on certain scientific questions, and that even Sir Roderick Murchison had been sitting at his feet and receiving lessons from him, the Thurso people took pride in naming the great scientific baker of their town."

The change of opinion was not, however, quite unanimous. When the joking rhyme about "Hammers an' chisels an' a" was published in the Wick newspaper, Dick wrote to Mr. Peach that "some people here view the matter quite seriously. One says, "Sir Roderick will 
regret having extolled me so highly: the verses are more like what a half-drunk Burns would write than anything they know.' A weak but well-meaning bodie at Cromarty sends me a pious bookie about the state of my soul. He says 'the spades, perhaps, are made that will dig my grave.' He need not have had any ' perhaps' about the matter. Kirk-yard spades bury three or four generations. A Dublin divine has sent me a letter that I have put in the fire, with 'There goes Balaam's ass, No. 1.' Indeed you know that the rhyme was solely made to make you laugh, while you were dowie."

The lion-hunters then came upon him. Point out a man who has done something out of the ordinary way, and immediately a tribe of nobodies flock to see him. If they cannot get introduced to him, they will look at him through his window, and try to see the lion through the bars of his cage. Dick hated all this nonsense. He would not be lionised. Every scientific man was made welcome to his shop, his bakehouse, and his parlour; but when persons, who knew nothing about science, merely called to see him as a show, he was shy and unapproachable. Some thought him rude. Yet he was exceedingly attached to those who were his genuine friends.

A gentleman called upon him one day and sent in his name. Dick was at work in the bakehouse. "Tell him," he said to Amnie Mackay, "that I am very busy, and cannot see him at present." Another message was sent in: "Tell. Mr. Dick that I am the editor of so and so." The reply was, "I have no time for editors ;" 
[Aside, - "They only thresh straw a thousand times threshed."] The editor afterwards stuck a prong into his back-after he was dead.

Dick detested sneakingness and dishonesty. One day a person called upon him and proceeded to say that a gentleman, well skilled in botany and physical science, then in Orkney, wished to call upon him, and that he had come beforehand to tell him so. It immediately flashed upon Dick's mind that this was the very person himself. He said, "It's of no use for your friend to call: I have no time for new acquaintances." The stranger then tried to obtain an interview through a third person, who was instructed to say that he was the person of whom he had spoken. "No, no," said Dick; "tell him not to come here, for if he do I'll say what I don't want to say to anybody." "What's that?" "I'll tell him to go to the __ ! " was the reply.

Many strangers, said a writer in the Northern Ensign, visited Thurso without being able to see his collections, although they had come for the express purpose. In this list we believe we can include a member of the reigning dynasty in France [Prince Lucien Buonaparte?] whom Mr. Dick refused to see, greatly to his disappointment. But when once, he adds, Mr. Dick had got the real measure of a man, and found him what he thought he ought to be, all was right, and the introduction of a stranger by such a person was the unfailing open sesame to his house and his curiosities.

Dick's servant and housekeeper, Annie Mackay, has said of him, that many people called to see her maister 
— some on business, but most from curiosity. He was polite to everybody. In business no man could be more civil. Sometimes people called when he was busy in the bakehouse. His arms and hands were covered with flour; and when the batch was in, he could not leave the oven. "You see," she said, "he had pounds and pounds worth o' bread i' the oven. Had he left that and come out to attend the visitors, the bread wud ha' been burnt, and he wud ha' Iost it a'. Wha wud ha' paid him for that?

"The Duke o' Argyll ca'd ae day to see the maister. He was thrang wi' "his batch. The maister said to the Duke that he couldna see him the noo, but if he wad ca' again he wad show him the fossils. The maister fix'd the time. He put oot the fossils and waited for a hoor ayont the time. He tell't me, "If the Duke come, take him up ta the parlour; I've taken oot the fossils and laid them on the table.' The Duke cam after the maister gaed oot, and looked at the fossils, but he didna stop lang. The maister was aye very particular about the time he fixed for visitors to see the fossils."

Sir George Sinclair of Thurso Castle usually brought his distinguished visitors to see Dick. Sir George had a great admiration for the baker. When speaking of his first visit to him, Sir George said :- "I had myself attended many courses of lectures at the Edinburgh University, and had acquired some knowledge of the various departments of Natural History; but, in conferring with my friend Dick, I soon discovered that all my acquirements were shallow and superficial. On 
those to which I had devoted attention I found myself completely eclipsed by iny acute and ardent friend, who was always as ready as he was able, to correct my mistakes, to guide my inquiries, and to add to my scanty stock of general information. The extent and variety of his scientific acquirements were incredible and almost

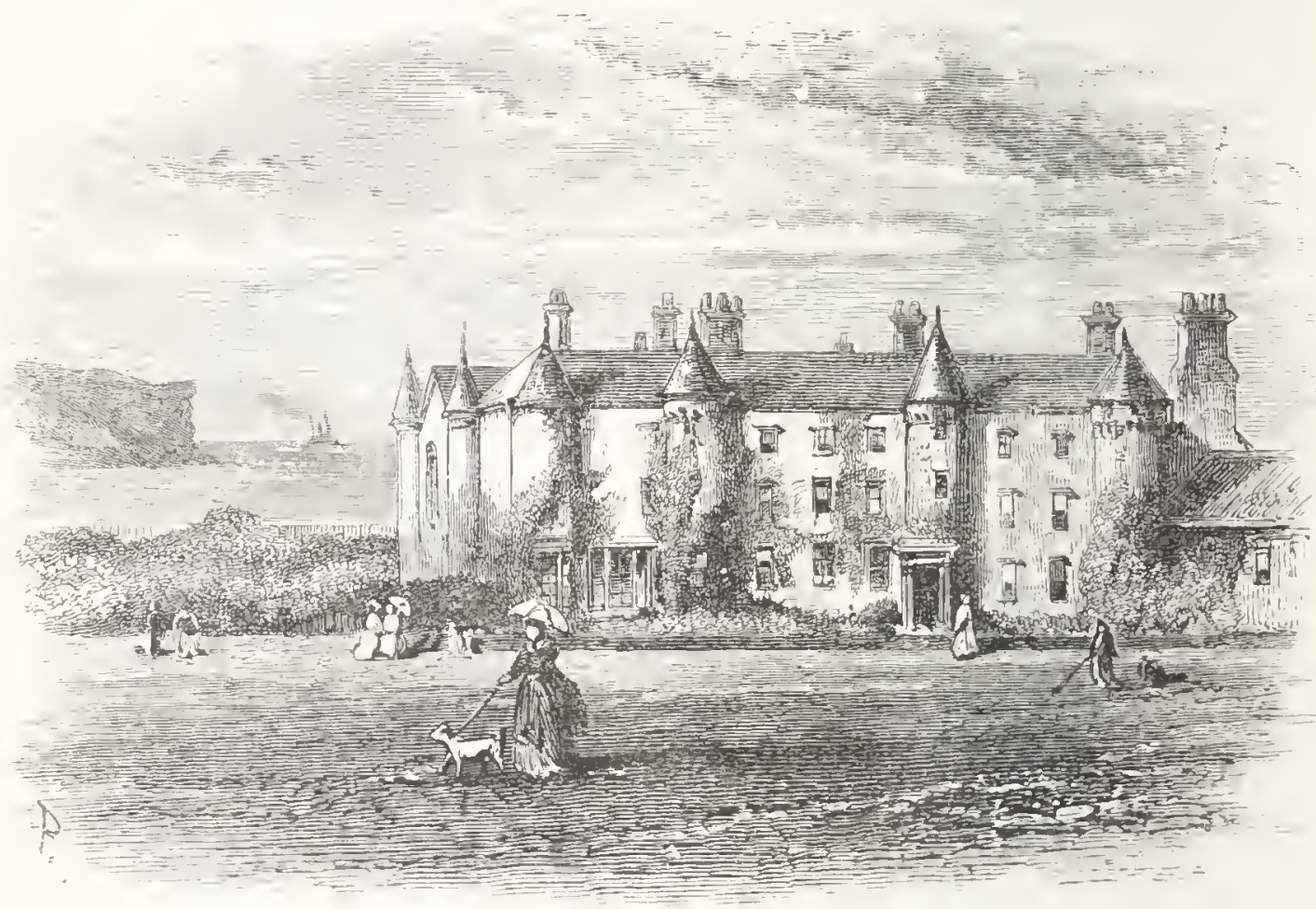

OLD THURSO CASTLE.

unexampled. He knew as much about many sciences as some professors know about one."

Amongst the numerons persons introduced by Sir George to Dick, were Thomas Carlyle and the Baroness Burdett Coutts. With the former he had but little conversation. They shook hands together across the counter, and exchanged a few words of congratulation. With the Baroness he discussed the discoveries of Mr. Pengelly of Torquay, another eminent rotary of science. Sir George often invited Dick to meet his distm- 
guished guests at the Castle, and to dine or breakfast with them. He also invited him to meet Hugh Miller there alone. But no! Dick would not leave his own house. He felt that he should be out of place in a Castle, served by footmen. "His unassuming modesty," said Sir George, "was as conspicuous as his wonderful knowledge." Lady Sinclair even proposed to change her baker, and buy her bread from him. "No, no," he replied; "I am the last person to take the bread from any honest man's mouth. Remain where you are; you cannot be better served."

When Mr. Peach proposed to visit Aberdeen in 1859, for the purpose of attending the meeting of the British Association, he asked Robert Dick if he would not send a paper, or communicate some facts through his friendis. "No!" said Dick; "when you go to Aberdeen I hope you will not speak of me at all. People bothered me so much last year after Sir Roderick made his speech at Leeds, that I have no desire for any repetition. Tell Mr. Cleghorn also (a geologist at Wrick) not to speak of me. I wish to be let alone."

But he was quite ready to sing a triumphant song . to welcome Charlie home again :-

O welcome Charlie hame again,

$\mathrm{O}$ welcome Charlie to your nain ;

The toon o' Wick has been in pain

For want o' her ain Charlie.

When Charlie went to Aberdeen,

The like before was never seen;

His coat was brown, his breeks were green,

His buckles shining rarely.

O welcome Charlie, etc. 
Upon his back a bag o' stones, His pouches fu' o' fossil bones; An' tangles lang as pipers' dirones Hang ower his shoulders rarely.

O welcome Charlie, etc.

When Charlie spak, the great were dumb, They felt they micht nae fash their thumb: For Charlie's logic was a drum That did its business rarely.

O welcome Charlie, etc.

When Charlie sat in committee The darkest doubts began to flee;

A touch ! a word! at once they see! For wha can match wi' Charlie?

O welcome Charlie, etc.

Among those who regularly called upon Dick at his bakehouse, were the medical students of the town and neighbourhood. These were always made heartily welcome. When Dick had done his day's work, he went out with them and pointed out the plants in their native habitat. Dr. Shearer informs us that there was hardly a medical student belonging to Caithness, who did not at one time or other make Mr. Dick's acquaintance. Amongst these were Dr. Meiklejohn, afterwards of her Majesty's ships "Tllustrious," "Harrier," and "Asia;" Dr. Brown, a well-known botanist, afterwards author of A Manual of Botany, Anatomical and Physiological; and Dr. Shearer himself.

Dr. Meiklejohn has told us of his first introduction to Dick. Being a native of Caithness, he had long heard of his devotion to natural science, and of the 
value of his researches into the palæontology of the Caithness rocks. When Dr. Meiklejohn went to Thurso in 1850, he sought an introduction to Dick through Miss Russell, bookseller, who had long supplied him with books. "We at once called upon him," he says, " and found him in his bakehouse, having just finished his day's work. I was much struck with his appearance. His massive forehead and fine features betokened a man of great intelligence. I regretted that he was not in a position to follow his scientific pursuits, free from the cares of arduous daily labour.

"On being informed that I wished to know the best places for procuring specimens of fossils which abounded in the rocks of the district, he said he would at once accompany me to some good fossiliferous spots. We walked out to Holborn Head, where, on an exposed surface of the rock, a magnificent cranial buckler of the Asterolepis was imbedded. This was the first example of that fine fossil which I had ever seen, and I examined it with the greatest interest. On our way back, he took me to the bed of a small stream near the Bishop's Palace, where numerous fossil fishes were to be seen. During my stay, we had many walks together. His acquaintance with the Fauna-particularly with the insects and shells-and the Flora of the district, was very great. I got much information from him on those subjects."

Their acquaintance continued. When Meiklejohn returned to Thurso - after his six months' study of surgery and medicine at Edinburgh-one of the first things 
he did was to call upon Dick. They saw much of each other during the three years that the young surgeon's studies continued. He accompanied Dick in his walks. "I remember," he says, "that he took me one day to a small pond, where he had found that curious little crustacean, with a bivalve shell, the Cypris. This little animal was of great interest to us both, as it is supposed to be allied to Estheria-a fossil not uncommon in the Caithness flagstones. It was formerly thought to be a bivalve molluse related to the little Cyclas of our rivers."

Dr. Meiklejohn took his degree in 1854, immediately after which he was appointed to H.M.S. "Harrier," which was about to sail for the Baltic, during the war with Russia in the same year. While in the Gulf of Bothnia, Dr. Meiklejohn sent Dick a long accourt of the Natural History of Finland. "I cannot," he said, "give you any elaborate details, as my only opportunities of investigating the coasts were, when I accompanied parties of armed men in boats, looking for ships,- frequently with a live shell by my side, and in danger of being picked off by a Russian rifleman." After the war, the "Harrier" left Portsmouth for Rio Janeiro and Pernambuco, cruising along the coast; and Dr. Meiklejohn again furnished Dick with a long account of the botany and zoology of the lands which he had visited.

Dr. Brown first made the acquaintance of Dick while on his way from the Orkneys to Elimburgh, where he was studying medicine. He called upon Dick at his bakehouse, and the two had much pleasant conversation. 
Dick supplied his young friend-for he was then only seventeen-with a list of the plants of Caithness. The list was a long one. The student read a paper on the subject to the Botanical Society of Edinburgh. He gave several of the plants on Dick's authority. The professor of Botany jeered at the idea of such plants growing in Caithness, and declared that Dick was all wrong! Dick was appealed to. He insisted that he was all right. He had seen the plants growing with his own eyes. What better evidence could there be of their existence in Caithness? Speaking of the affair to a friend, Dick said, "I doot the folk that objected were fireside botanists."

The correspondence, however, continued. In one of his letters, Dick said, "I am sorry that my doublymarked list of plants should have annoyed you so much. It is impossible for me to send my dried plants to Edinburgh for examination by your Professors. The plants are bulky, - and besides, I value them too highly to allow any person to touch them, except very tenderly. How can I forstand your Professors, when they dinna forstand themselves."

"Saxifraga tridactylites: Dunnet Links. QueryWhy do your Professors doubt my word about so common a plant as that? Is it because I said it might be had in millions?... Arbutus alpina: native. . . Luzula Forsteri: my nainsel fand him. . . . Osmunda regalis. Eh? Weel, man, were Dr. Johnson of Berwick alive, he would roar so loud that they would hear him at Morven. Osmunda regalis has just as good a right to 
be considered native as Calluna vulgaris. . . . You will please give all this news to Professor Balfour. Tell him I am just as jealous of my rights as he can be himself.

"I truly grant, a hundred times, My skeel may weel be doubted, But facts are chiels that winna ding, And needna be disputed."

Another letter from the medical student follows, in which he offered to assist Dick with specimens of plants; to which the baker, perhaps tired of the subject, said"I hope you will dismiss from your mind the idea of hunting out dried plants for me. Attend to your studies, and leave me to find plants for 'mysel.' ... Those plants exist in Caithness some way. How can I tell how they got there?"

The correspondence was not yet over. The student, on his way home to the Orkneys, called upon Dick again, made up all differences, and got from him some of the wild Caithness roses, - the whole of which Dick had tracked to their lonely haunts among the hills and the straths. In a subsequent letter, Dick says, "I could pick three or four roses of different 'varieties' from one wild rose bush in various stages of transformation. I don't consider myself beat on that point yet. Nor will I rest satisfied until I get the decision of some authority. I'll wait, even for twenty years. Spes in,fracta. What's that? Gaelic? May be so-may be no. It's all the same. I'll wait! . . Thanks to you for giving me the Goat Honeysuckle, and the Woodsia from Dumfriesshire. I'll thank you quietly ilka time I 
look on them, and that's better than noise. . I. C. Watson most certainly has me on the hip about Potamogeton plantagineus; but I have as certainly floored him about the Buckbean (Menyanthes).... The season of wild flowers is over once again (September 1860), and I am not likely to wander far this year. I have never walked less in all my life than this summer. Wishing you all the happiness in this world, I am," etc.

In the following month, Dick writes to his young friend, "You are all right; and we are sworn friends;" and again, "I can't quite make out your hieroglyphics They are a mystery to me. You can write better than I; only don't drive quite so furiously. I was never at college!" Then he goes on to the Caithness roses again. "Along with this you will receive your catalogue, which I have gone over very carefully, and made some notes thereon. You have omitted some which are very common, and others, which, though less abundant, are found here. I have marked no roses save Rosa spinosissima, Rosa canina, and Rosa micrantha. They are abundant on the braes, by Thurso river, for miles inland. In dry seasons, the leaves appear almost white from their hairiness. On a hill six miles away, there grows a rose; another fourteen miles away; another twelve miles away; another six miles away, on the edge of a cliff overhanging the sea, and exposed to the full sweep of the northern tempests. I had intended to have sent you specimens of all these roses. But the heavy rains forbid:

"'The best-laid plans o' mice and men

Gang aft aglee.' 
"But what ails Dr. Balfour? I am wearying to hear what these roses are. He need not hesitate to say what he thinks. I lay traps for no one.

"How comes it, that of all the Scotch heaths, Erica Tctralix only should be given to the habit of putting out varictics. I have watched Calluna vulgaris and Erica cincrea, and never yet, among thousands of thousands, found a notable variety. But with Erica Tctralix, the loveliest of the three, the case is very different. It is subject to strange shiftings and changings, and I have some delightful varieties from it. If Erica T'tralix was sent to some Darwinian academy, wonderful results would undoubtedly follow!

"Your society doubted whether the variety of the lady fern, known as Athynium molle, was really native to Caithness. Since I saw you, I have got two specimens of the fern from England; but Dunnet Cliffs produce far finer specimens of the same fern. Take my word for it. I have got two specimens of the variety rhocticum from England; the same fern is also here.

"In your catalogue, I observe that you have marked Poa aquatica as a native of Caithness. That is serious. The red Poa does not grow in Caithness."

"I'll not write to you again for three months. Attend to your studies."

We have quoted these extracts to show how thoroughly Dick had mastered the botany of Caithness. He wandered over the country far and near-in spring, summer, autumn, and winter,- - and collected all that grew during those seasons. 
Strange to say, he missed an object that he had long been looking for. It was the Juncus squarrosus, which is usually found growing on boggy earth. He searched for it along the banks of the river, but though there, it had been cropped down by the beasts which grazed along the grassy plat. At length he found the plant growing to perfection not a hundred yards from his own door,--on a piece of land called "The Island"a place devoted to the bleaching of clothes, and consequently sacred from the intrusion of cattle.

During the later years of his life, Dick again returned to the study of botany. He searched all the country round, for grasses, ferns, and mosses. What an insignificant thing a Moss seems! Yet, when a friend was complaining to Linnæus, that Sweden did not afford scope enough for the study of Nature, the sage laid his hand upon a bit of Moss on which they were reclining, and said, "Under this palm is material for the study of a lifetime!"

Every one remembers how Mungo Park, when lost in the desert, was delighted with the sight of a tuft of Moss. The little living jewel, growing amongst endless wastes and arid rocks, melted the traveller's heart. "If God cares for the moss," he said, "surely He cares for me;" and Park went on his way with an uplifted heart.

Dick searched the whole county of Caithness for the mosses which it contained. He was the first local botanist who had investigated the subject. Writing to Peach in April 1856, he said:- " The club-rnosses are very interesting plants. I have found five out of the 
six British species growing in the county, and probably I may also find the sixth. The club-moss which strikes you, is alpinum, which is found in great abundance on the steep sides of Morven. Selago, or fir club-moss, seems an exception. Selaginoüdes too, bears spores everywhere. . . I I am scarcely master of a single spare moment."

"I am going off to the moors," he again says, "for a back-burden of moss. If you were here you would go too, but you would have to rise at five. If you will visit quarries, my man, it will not do to be snoozing in your bed until eight o'clock. I was up at one this morning, hence this epistle." This, however, was a piece of banter; for Dick knew that Peach was an early riser, and did much of his geological work early in the morning, or late at night. "His letters," said Peach, "even if bantering me, always brought sunshine."

Dick also continued his search for ferns. He often wandered along the foot of Dunnet Head, when the tide was out, and climbed up the rocks into some shady nook where the ferns grew. They did not grow on the eastern side of the cliffs, but on the west, where the Gulf Stream washes along the headland. Sometimes he descended the western cliffs, where a fall of the red sandstone had taken place, and there he found the forns of which he had come in search. It was a glorious day for him when he found the Royal Fern-Osmunda regalis - growing there in its native beauty. "I can yet recollect," he says, "how happy I was when I found the first Osmunda. I was wearied, and sore, and sick, and 


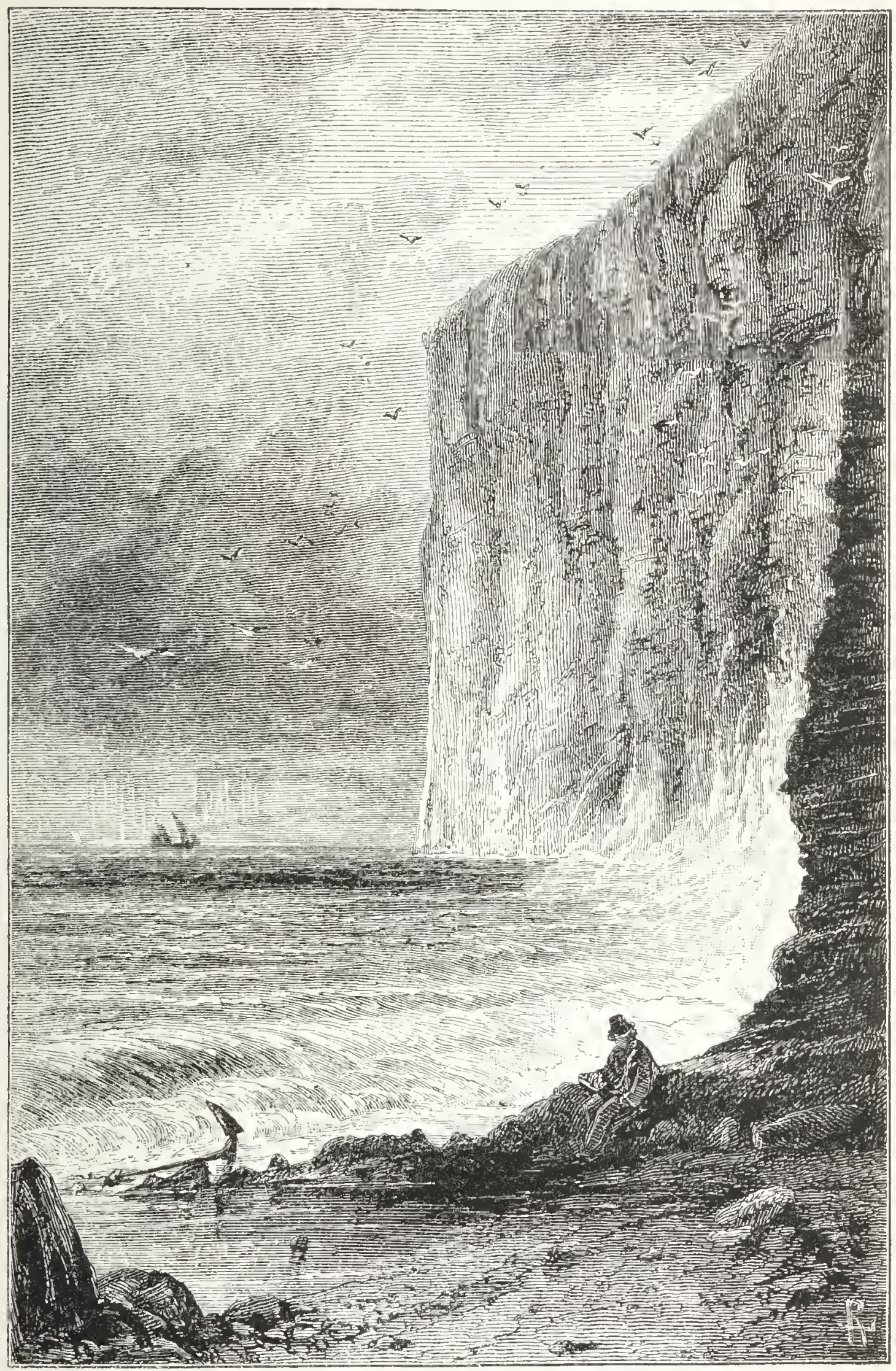

DUNNET HEAD: WEST FRONT. 

nearly tired of this world, and all that's in it, when I caught sight of that glorious Fern, large, radiant, and flourishing, among the reft sandstone cliffs of Dunnet. What a beauty! Almost approaching to the size of a tree fern!"

Dick also found among the rocks on Dunnet Head, Lastrea dilatata, Lastrea fceniseeii, the Asplenium marinum, Asplenium filix-formina (lady fern), and numerous other ferns. Morven mountain was also one of his haunts, and there he found Polypodium Phegopteris, $P$. caleareum, and Lastrea Oreopteris. Braahnabin and Dirlot also furnished him with many specimens. The commoner specimens he found all over the county. He collected many of the seeds and plants, and sowed them and planted them broadcast over the county, to be living when he was dead. He planted scions of the maiden hair and the royal fern in the gorges of the Dorery hills, at Morven, and in his fernery at Reay.

Mr. Peach helped Dick in his inquiries as to ferns. He often sent him seeds or plants, so that they might be planted in favourite spots. He also sent him some Cornish heaths. "Many thanks!" said Dick, "for Erica vagans and Eriea eiliaris. To me they are a world of pleasure."

Having been informed by Mr. Peach that he had found Asplenium marinum at Strathmore, ${ }^{*}$ Dick says, "Nothing that you ever mentioned to me has struck me so much as what you say about Asplenium

* Mr Peach says this must be a mistake. Still Dick's letter wus written on the supposition that he had found the plant, and it shows how thoroughly he was acquainted with the plants along the coast. 
marinum. ... I have examined every accessible seacliff from Portskerra to John o' Groat's, and never yet found a trace of it. A. marinum on the slaty rocks! How is that to be accounted for? Certainly not owing to the exposed nature of the coast, nor to the sea spray. I have clambered down the north-western point of Dunnet Head, where the northern storms waste their fury on the cliffs, and the sea spray is lifted in vapour high over their loftiest pinnacles, and even there $A s$ plenium marinum loves to nestle among its crevices? The distribution must be a mystery."

Peach sends Dick many plants for him to name. He sent the Polygonum viviparum. "It is a rare alpine plant," was the reply. "It is not a fern at all, though it is nearly as rare as your treasured Dryas octopetala, in search of which I have spent many a long day. Your orchis is Habenaria chlorantha; your fern Cystopteris dentata: it is decidedly rare. Thanks for allowing me to rob you of Scolopendrinm (Hart'stongue). . . A plant I have gathered here," he says, "I have dried and submitted to an English professor (Babington). He has pronounced it to be one of the very rarest in Britain. The plant is rare, but not so rare as the professor kindly wished to make it.

"Not content with the specimens of the fern which I had got beside me, I set out (July 23) for a mountain nine miles away, where I knew the plant grew; and in due time I got there, and saw, or thought I saw, many different species. On on sloping brae grew Poiypodium Phegopteris, and I sat me down beside it. I remarked 
that, though of all sizes, from an inch up to twelve inches, every one was true to the type. Passing on to a rocky ledge, I saw a cluster of the fern I had gone in quest of. Down I sat, in admiration wrapt, the world forgot! What was the world to me, with its pomps, and pleasures, and nonsense? Away with printed books and dried specimens! Nature, ever enduring and captivating Nature, is the best of all books to study from. That, said I, is the Polypodium Dryopteris of learned men. More than fifty of the fern were growing before me,-not one of them agreeing in any particular with the Dryopteris of the books.

"When I had gathered the plants, I sat and looked around. The day was warm and delightful. A thin haze was dancing through the air. The effect was charming, tempting one to dream. Through the mists of Mirza I could see a human figure at the hill foot, stooping low to the ground. Probably, thought I, some broken-hearted pilgrim is providing for futurity. I turned round, and after a while I looked again. Alas! it was a half-naked woman filling her stomach with cold water. The spell was broken. It was time to ba gone. Adieu, old boy!”

In this way was the pleasant correspondence of the two geologists carried on. There was no envy, but every kind of helpfulness between them. Peach told his discoveries to Dick, and Dick told his to Peach. There were many discussions between them, more particularly as to Peach's fossil wood. Dick said that under Peach's supposition "a stone quarry becomes a 
buried forest." Yet Mr. Peach held that he was right. And Dick also worked hard to get at the right meaning of things.

On one occasion he writes to Peach as follows:-- "A few days since I found myself standing by the seashore on the east side of Dumnet Head. I was scanning with delighted soul the overturned strata, and musing on the Past, on the Beginning, on Eternity!

"I am again bothered with rheumatism, and neither an enthusiastic love of stones nor fossils can delude me into the belief that pain is an illusion, and not a stern reality-intended no doubt for good, and yet I had as lief be without it-

\section{" Oh! age has weary days An' nights o' sleepless pain ;}

The gowden time o' youthful prime Can never come again!'

That's the old man's song, Charlie. But it is all owing to temperament or constitution, or to stamina at the outset.

"I felt consideralle chagrin when you returned from the West, and brought no root of Scolopendrium with you. I did not want it for myself, but for science and Nature. I wished to plant it on Dumnet cliffs, or on the slate lills to the south of Thurso. I know favourable spots where I think it would live, and gratify the weary souls of lonely pilgrims, long after you and I are singing hallelujah with the angels. If you don't send that Scolopendrium, your monument in the North will have no garland hung around it." 
A little later he again complains of illness. $\mathrm{He}$ says, "I can't bear mental fatigue. I am weary and sore. The buzzing of a fly is a burden to me. I slept only three hours last night. My head is sore, and I am not ' $i$ ' the vein.' You compliment your humble servant, and ask assistance to your list of queries. I know a little-just a little, and am daily making the little more-the mark of a true Scot; yet in the imperfect knowledge of the Caithness strata I would not, for crowns, or robes, or kingly globes, put my unhallowed hands to a fancy section of Caithness strata."*

At length Peach sent him the Scolopendrium. His sickness had fled, and he was quite jubilant in his repiy. "I have planted it," he said, "among the magnificent crags of Dunnet Head. A bronze pillar should reward the person who introduces into a county such a lovely plant as the Hart's-tongue fern, ever verdant, ever gay. What beautiful green fronds! How handsome and picturesque! My only regret is that I camnot sow it broadcast over the whole land."

A little later Peach sent him another lot of the Hart's-tongue ferns from Sutherland. Dick proceeded to plant them far astray, so that they might not be huddled together into one corner. "I prefer," he said,

* Sir Roderiek Murchison had requested Mr. Peaeh to furnish him with a seetion of the rocks between Morven and the Orkneys. "What?" said Dick, "a seetion of Caithness strata without previous examination? It would be a mere fancy section of the whole eounty's hard crust, to the delusion of ail and sumdry." He adds, that he rejeeted Hugrh Miller"s "scetion of Caithness strata, as based on defective data and misleading calculations." 
"the fatigue of planting them as widely apart from each other as possible, so that they may scatter their colonies. In long years, after you and I are dead, and perhaps making 'a bung for a beer-barrel,'* they will be fresh and flourishing. . . . It was not for vanity that I begged them from you. No. It was the certainty that in generations yet unborn the feeling that 'vanity of vanities, all is vanity; would weigh down and oppress, and that some wanderer sad might be made happier by seeing them. For is not a 'thing of beauty a joy for ever'? Bless and thank you, my dear Charlie! They'll never thank you. That's my duty! One cannot but admire the Wisdom which gave and gives a feeling and a sense of the beautiful even to the ignorant. Were it otherwise, Beauty would not exist; and to the Allknowing how small is the difference between the sage and the sarage!"

A little later Dick says :- "I have planted the Royal Fern inland many miles. I have planted it at Reay and I)orery. There I can see the hills of Sutherland far in the distance. Aided by my zealous friend Charles the Sissenach, I have adorned and beautified Caithness. I write this in the midst of care and trouble. I have a bad cough, and no more romance at present.

* "Why may not imagination traee the noble dust of Alexancler, till he find it stopping a bunghole? . . . Alexander died, Alexander was buried, Alexander returneth unto dust; the dust is earth; of earth we make loam; and why, of that loam, whereto he was converted, might they not stop a beer-barrel?

"Imperions Cesar, dead and iurned to clay,

Might stop a hole to keep the wind away."-Hamlet. 
Robin's head's sair. It's a desperate thing to fill up a page with a bad headache. I am glad that you are in spirits at least, if not altogether in liealth. So many people are going that I began to be apprehensive that you were seriously ill. ... Cliarles, old boy, go when you may (unless I go first), I shall seriously miss you.

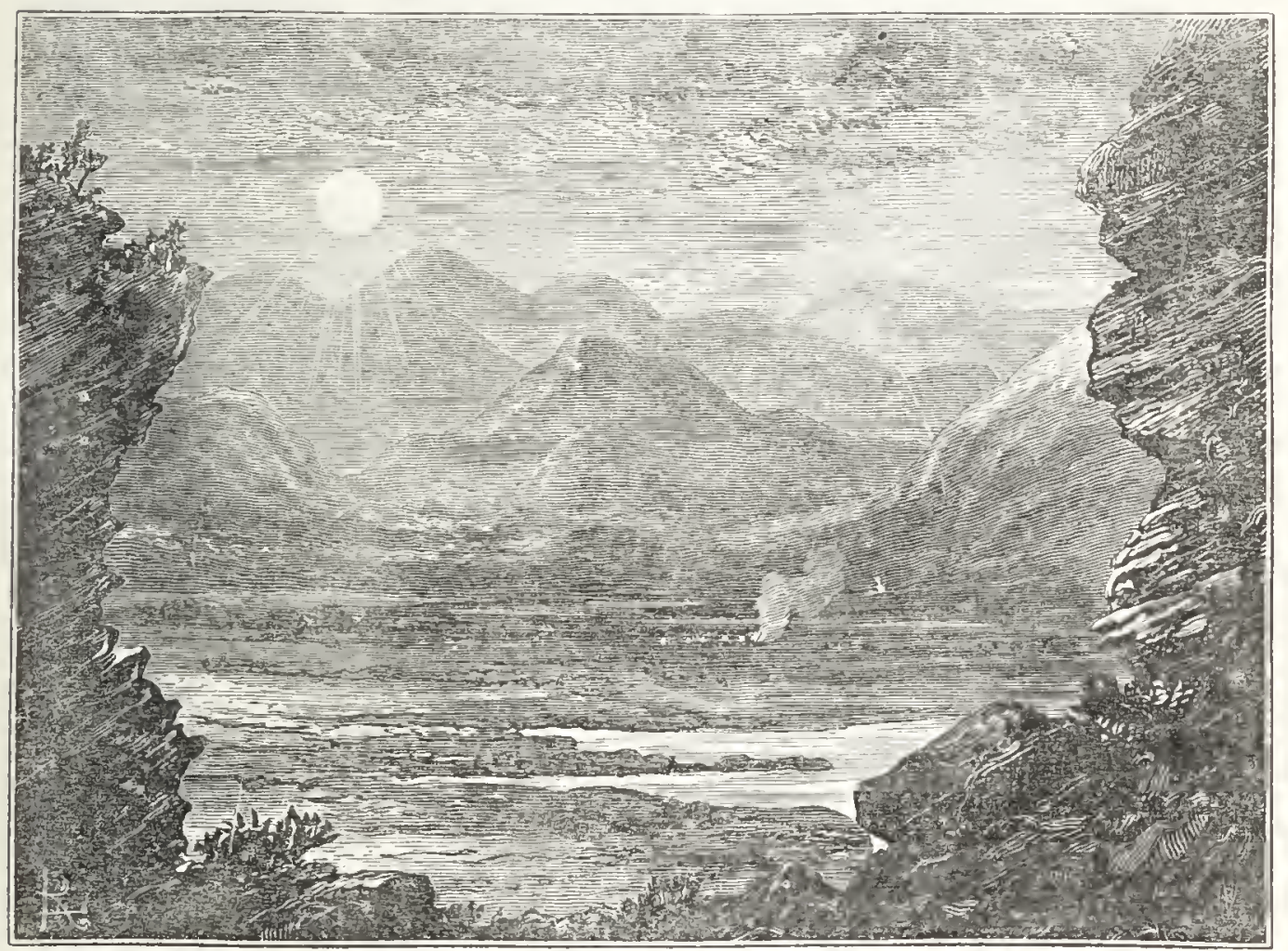

RODERT DICK'S SEAT: VIEW INTO SETIIERLANDSHIRE.

I miss Hugh Miller as much as ever I did, and 'tis likely I will ever do so."

Mr. Peach says that Dick had so thoroughly examined the botany of the county, that for some years before his death he could discover nothing that he had not before met with. "I well remember," he says, "when asking him ' what there was new,' his eye brightened up, and he answered, 'Just this one plant new to the county. I was giving up my botanical search, and returning home 
after a long evening walk from Dunnet Links, when I lighted upon this pretty umbelliferous plant-hedge parsley; and here it is !' Thus, so closely had he looked up the plants of the county that for some years he could scarcely discover another. Had he been persuaded to give his thoughts to the world, he would have stood very high in the ranks of scientific authors. But he never could be induced to publish his observations and discoveries. He could not get over his bashfulness."

Many discussions about geology occur in the course of the correspondence. Peach sent Dick Darwin's Journal to read. Dick replies:- "Though the book was never in my hands before, yet I found that I was already familiar with most of the facts it contains. Sir Charles Lyell draws upon it rather freely. And in various other works I have met with his craft. $\mathrm{He}$ is a fine fellow. ... He traverses the widespread Pampas of Buenos Ayres and Patagonia, rides over their accumulated sand and pebbles and their sepulchres of dead bones, and he is overwhelmed and bewildered at their magnitude. But why should he be astonished? The sands are many, it is true, and the boulders and stones innmerable; but the sea, the million-handed ocean, that rounded them in his palm, is vastly more extensive. The sea is a workman that never wearies, never rests, never slumbers! Thanks to you and Mr. Darwin, the perusal of the book has confirmed me in all that I told you long ago. . . . Humboldt half guesses that the living and the fossil animals belong to the still existing creation, but it seens to be convenient to withhold the avowal. 
"Nobody knows when this earth was made, how it was made, or how long it was in making.

"Of one creation part we ken,

Wi' mair we dinna meddle;

Ance dream o' twa, ye'll dream o' ten,

An' fancies endless_-diddle!

"Don't think that I do not value Mr. Darwin. I have read his observations most carefully, but with my own spectacles. Geologists have led me such a dance during the last twenty-five years, that I prefer that way of reading books.

"This earth on which we move may have been created very long ago, but certainly most of the regions visited by Mr. Darwin exhibited very few signs of a hoar antiquity; and despite previous teachings and their influence, the very recent nature of many of the deposits forced itself upon his attention." After quoting from Humboldt, Professor Sedgwick, and others, he continues the argument in favour of his own views. He concludes thus:- "I remember that when friend Hugh set down in print that all that lived previous to and during the chalk died out with the chalk, and not one existence was spared; yet when, after a time, a species of shell was found in tertiary and chalk strata, the geologists very dexterously clapped those tertiary strata alongside and with the chalk, just to make things tally! How will they manage now?"

Dick deprecated the idea of explaining the universe and how it was formed, but he threw out the following idea of the greatness of the thing attempted to be ex. 
plained, and the littleness of the things attempting to explain it :-

"Take a cupful of sand and strew it over the floor. It is a mere sprinkling, scarcely discernible. A fly settles down on it, walks over and across it, and regards it as in no way remarkable. A smaller creature than the fly comes and walks over it. To him it is a very great matter,-quite a Sahara! Now, were the whole of the formations of geologists, by some superluman power, let loose particle from particle, and the whole strewed over the floor of the ocean, would they form more than a mere sprinkling?

"Brush the cupful of sand together again. It forms a little hill, or, if of a lengthened form, a mountain range. The fly from your window comes again and settles down beside it. He loolss up. 'How magnificent!' says he. He walks round it and over it. 'How vast! millions and millions of years must have been consumed in their formation!' Ignorant, simply ignorant, all the while, of the means by which a body of matter so apparently formidable to his puny ideas was brought together. The fly will not understand it, but he'll buzz and buzz, and make a noise; and his fellow flies, hearing the noise, will exclaim, "What a longheaded fellow!' "

George Shearer of Thurso, then a student at Edinburgh, was a great admirer of Dick. He got from him a great deal of lis first knowledge of botany. As in the case of Dr. Meiklejohn, Dick took lim to see the plants growing in their native habitats. They had con- 
versations on many subjects. But there was one subject on which George Shearer was particularly anxious to know Dick's opinion; and that was his views as to the Mosaic Cosmogony.

Accordingly, he wrote to him from Edinburgh on the subject. But Dick was not to be "drawn" by a person so much his inferior in years and knowledge. He replied :- "As to your religious queries, my answer isOn religious matters we are not equal. I am within three months of being fifty-three years of age. Wait until you are as old, and wearing spectacles, and then we will discuss those matters. Meantime, as you cannot rest, you will probably be writing a commentary on the Romans. My advice to you is, 'Tak' tent; let sleepin' dogs lie!'”

This reminds one of a story told of the late poet Rogers. When asked by a lady what was his religion, he replied, "I am of the religion of all sensible men." "And what is that?" asked the lady. "All sensible men," replied Rogers, "keep that to themselves."

Dr. Shearer, many years after, when grown to manhood, said that Dick must then have thought him somewhat of a prig. "I took his reply," he says, "in excellent part. I felt that, when he wrote it, he thought that the unthinking may easily be orthodox, and that the loudest professors were sometimes the shabbiest actors in the drama of life."

Dick was of opinion that dogmatism in interpretation, was equally out of place in geology as in divinity. He thought that man's proper work at present was to search 
and acquire new facts and materials for the formation of further knowledge. Theories might wait. Certainly the time had not yet arisen for harmonising the Testimony of the Rocks with the first chapter of the Book of Genesis.

Dr. Meiklejohn aggain resumed his correspondence with his friend Dick on his return to England, while surgeon of H.M.S. "Asia." Dick replied to him at once. He began his letter to the doctor with a little bit of censure :- "If I were to plead busy, as you do, as an excuse for not writing, I think I would never scribble a word at all. I rise generally at three o'clock, and am for the most part engaged all the day until I go to roost at nine o'clock in the evening. Nothing but thirty years' practice could have enabled me to endure such a galley-slave life.

"I have not seen Sir Charles Lyell's book on the Geological Age of Man, and should I see a review of it I must be on my guard, for I fear I am too straightforward in expressing my notions on these and other fashionable speculative dreans. I have seen Darwin's book on Orchids very coolly reviewed in the Athoncum. I have no wish to meddle with Mr. Darwin's peculiar notions. . . . One thing, indeed, I'll grant Mr. Darwin - that hundreds of so-called species may have sprung from one stock. I have been lately looking at grasses, and rould not care though Mr. Darwin made all the species of Poa and Festuca to have grown from one plant. And so of many more of them."

In a future letter Dick says :- "I am sorry you think that I do an injustice to Mr. Darrin, as I would not 
knowingly do an injustice to any one. It is quite possible that, in my ignorance of what that gentleman's true views really are, I may have spoken rashly and hastily. That you can pardon, for in truth I have never read one of his books, and the reviewers of them may have twisted his meaning to serve their own purposes.

"If what Mr. Darwin means be, that the various animals and plants we see around us are not exactly first creations-that is, are not now what they were when made by the hand of the Almighty, but have since that act been changing continually, so that it is now difficult to say from what particular stock the various forms have come-if that be all, if not pushed too far, it does not seem dangerous doctrine; in fact, it looks rather playful, and at the same time it may have much truth in it. I can myself see that it is and must be difficult to determine from what particular stock many species of plants have sprung. For that every species, made such by man, was a particular act of God's workmanship, is out of the question. That idea I cannot admit at all. Cuvier's definition of a speeies may be the right one, but surely it is rash and presumptuous. How can I or any man, while looking at a plant, say that it has maintained all its particular characteristics unchanged since it came from the hands of its Maker?

"Since I have looked at Scotch roses - for example, the very small lot of them to be met with in Caithness -I have found much to correct my earliest ideas on creation, such as my teachers (knowing as little as I did myself) instilled into me. I thought, even since I read 
books on plants, and looked on the coloured figures, that the various species were well marked, and must have had a distinct origin. I confess that that notion is fast leaving me. All my simpler ideas are giving way. Whether the result will be to make me happier or better I cannot say. Certainly they cannot hurt me, for, after all, first stocks must have had a Creator. They could not spring up out of the ground unbidden, and that is enough for me. There is an over-ruling Hand everywhere.

"External influences-such as soil, situation, climate, and such like-exercise a powerful effect on wild roses. Take, for instance, the Rosa spinosissima. You know its peculiar characteristics, and how very unlike the common dog rose (R. canina) it is. Would you believe that one bush of it on the boulder clay here, has put forth flowers hardly distinguishable from dogroses. The leaves large, the flowers white, the prickles hooked, and so on. Tou have seen roses in country gardens? White roses in a corner, with double flowers, and very large unsightly leaves. Well, would you think or expect Rosa spinosissima to have such large unsightly leaves growing wild on hard boulder clay? Some stocks of $R$. spinosissima have pink petals; in dry years, red petals and excessively hairy leaves; in wet seasons, white petals and smooth leaves; in short, the leaves and the whole plant vary excessively. And suppose the plant changed to another soil, and favoured by shelter, its improved appearance is hardly credible.

"I have seen something wortl noting. Some plants of. Rosa spinosissima grew on the face of a brae of blue 
boulder clay. Drains and improvements on the soil atop of the clay sent a perpetual stream of water over the roots of the plants. In two years they have so altered that I can hardly believe my eyes. . . . All the roses growing wild in Caithness may have come from one stock; but from what particular stock I cannot tell."

We merely quote these remarks from Dick's letters to show the acuteness and accuracy of his observations. He never missed any peculiar characteristic of a plant. He had also a wonderful memory about it, and could contrast its appearance during one season with its appearance in another. It was the same with all his natural history observations. In one of his letters to Dr. Meiklejohn he refers to the mischief done to the fields of Caithness by a particular grub. "Speaking of grasses," he says, "reminds me of the crops of Caithness. They are desperately cut up by a worm, of what particular species I'll not say, but the grub of 'Daddy Longlegs' (Tipula oleracea) has certainly the predominance. It has drawn after it whole flocks of starlings, who are driving a brisk trade. But it would require millions of them to stay the plague. Indeed, the work of ruin is already done. It is pitiful." 


\section{CHAPTER XIX.}

\section{ROBERT DICK IN ADVERSITY.}

Flowers, ferns, and mosses, must for a time disappear, and give place to troubles, disappointments, and sorrows. It is a hard work-a-day world in which we live. Misfortunes follow close upon pleasures, however innocent; and we must set ourselves to bear them as best we may.

Dick was never a rich man. The most that he could do was to make both ends meet and keep out of debt. He could even spare a little money to buy books. Before 1860, we find him buying from the Thurso booksoller the History of British Lichens, the Coloured Ferns of Britain, Soxierby's Ferns; and the Handbook of British Mosses.

But after that time his business fell off rapidly, and he had to be more sparing in his book-buying. It must be said of Dick that he closely attended to his business. Only once do we find him confessing that he had stolen a morning from his daily work; and that was when he went on his long journey to Freswick, to search for shells among the boulder clay for his friend Hugh Miller.

Though he often left the town at midnight, his bread for the following morning had been baked before he left. It was sold during the day by his housekeeper. And 
he was always back to Thurso to resume his work on the same evening. During the interval, he had been rambling over the county, and sometimes walking from fifty to eighty miles - wandering under the red sandstones on Dunnet Head-or travelling to Reay, the Dorery Hills, or Strath Halladale. His journeys to Morven were usually made on the fast days, which gave him a day extra.

He lost his business principally through excessive competition. When he first went to Thurso, there was only another baker besides himself. He was then comfortable enough,--though he did all his work himself,never employing either a journeyman or an apprentice. Two more bakers commenced business in 1856. Each of these took a certain share of his trade; and, of course, his business fell off. Writing to his sister in May 1856, he said: "The mischief done me can never be repaired here. I've lost much, and am still losing; and what is worst of all, I am losing my health. I have not had a day's health since February last, and goodness knows that if I had to take to my bed all would be over. And is it not very hard, and a poor reward for the twenty-five years of toil and privation that I have had? Very hard indeed! I wish I could get away; but where to, or what to labour at, I know not. To go abroad seems ridiculous in every way, as I would either have to try to be a shepherd or a day-labourer. Sometimes I think I might contrive to work in a maltkiln, but perhaps I could not get that even if I tried. "And thus my existence is embittered. Years, many 
years ago, I saw the dark clouds gathering close about me; and now it has all come true. Often was I on the point of leaving. But infatuated procrastination always whispered, 'Try again.' I did 'try again,' but it was of no use. It only led to further loss. And losing, and losing slowly though surely, in spite of all my toil and care, until my small means are so reduced that I hardly now dare to look into the future. $\mathrm{O}$ if I had only gone away four years ago! If I had gone then, I should have been stronger in Means, stronger in Health, and, above all, stronger in Will and determination. Alas! I feel that by and by I shall be as soft as a piece of boiled fish!"

Though still engaged in finding fossil fishes for Hugh Miller, and collecting botanical specimens from the grasses, ferns, and mosses of Caithness, the thought was constantly in his mind of how he could get away from his losing business. At one time he thought of getting admitted to the Coastguard service; but he found that he was too old for the position. But could he not yet remove from Thurso, and set up as a baker elsewhere? Muckart, a village near Kinross, was mentioned to him; but he said, that "no man in his senses would set his foot there." Then Bannockburn, near Stirling, was mentioned: would that do? "No," said he; "I have a dread of weaving places. Weavers often suffer great misery, and a stoppage of trade is clean ruin." Another place was mentioned, where a business was for sale. But he had not the means of buying or carrying on the trade. And thus he was left at Thurso, to "try again"! 
Matters became worse and worse. More bakers appeared in Thurso, and his trade again diminished. Some of them sold whisky and groceries, besides carrying on the baking business. Whisky was a great competitor; for Caithness folks are very drouthy. The Reverend William Smith of Bower, whose members, and even whose elders, were much addicted to the use of spirituous liquors, once addressed his congregation as follows: - "My brethren, we are told in the Scriptures that the elders of old were filled with the Holy Spirit; but nowa-days, they're filled with John Rarleycorn!" One may guess the wind-up of his sermon.

Dick was thus very heavily handicapped, as he lived by baking alone. He then thought of carrying on a tea business, and thus adding to his income. But the idea was abandoned. One of the whisky and grocery bakers determined to undersell all the bakers in Thurso. He did so, and afterwards became a bankrupt. But Dick gained nothing from that. In the contest he was nearly ruined.

"How many bakers, think you," he writes to his sister in 1862, "are now in Thurso? Six master bakers, and thirteen apprentices! All doing well, they say! Who rises earliest? Dick. Who is the oldest? Dick. And yet Dick has not made a fortune! I wish I had left here in 1843,- - that is, eighteen years ago. There is no use in repining. Yet how manfully I have battled, no one knows. You see, from one of the papers you sent me, that a baker's wife at Alva drowned herself in Devon river, and that a baker at Cupar-in-Fife bas hanger himself. It dil not surprise me." 
His sister offered to send him money and clothing. Robert refused the help. "Things have not come so far as that yet," he said. "If they had, I should need a strait jacket. To those who have to struggle by their labour for a living, the prescription of coddling and nursing is about the worst treatment imaginable. It is neither good nor profitable in any way. When any man or woman consents to receive such things as you spoke of, and for such a purpose, then adieu to all self-dependence and self-respect. Then, ten to one, the individual would become degraded and useless. You have no idea how injurious it is, both to soul and body, to wear next your skin what one never toiled for. Besides, your income is little enough for yourself."

And yet Thurso was improving. Many new inhabitants were added to the town, but very few of them came to Dick's counter for bread. Pavementcutting had superseded herring-fishing. Many new flag quarries had been opened out, and those who had fished for herrings now cut flags for parement. Many of the old Highland cottars, who had been driven from their homes, also resorted to Thurso for the same purpose.

"In fact," said Dick, "the flag-trade here is everything; * and the town increases from day to day, chiefly by additions from the surrounding country. The

* When the authol was in Thurso he was introduced by name to an emineut flag-cutter. "You will know this gentleman by his works?" "Ay; where are they? I never heard o' them." "I mean his literary works." "Ou, is that it?" Thus flags, not books, rule the Thurso world. 


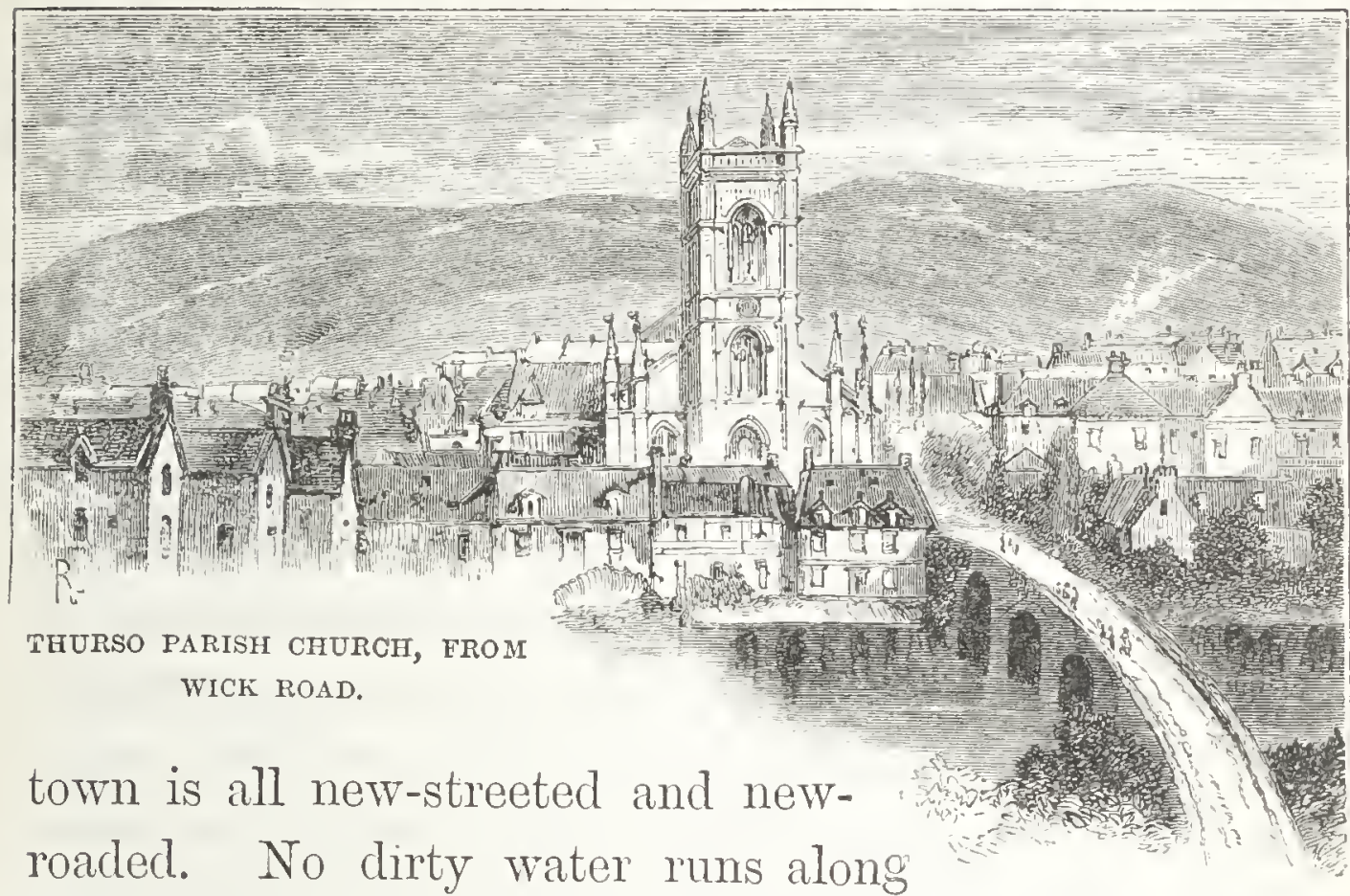

them now. There are three policemen to keep down dunghills. We have three new churches, two new banks, and a gaswork. There is a fine statue of Sir John Sinclair in front of the Moderate Kirk, alias the Establishment. We have a new hotel, a new court-house, and new shops. Whole rows of new houses have been built. We have a steamer to Orkney, a steamer to Leith, and a din about a railway. In fact, nearly everything has been changed, except the fields round the town. These remain very much the same, being fenced with flagstones set on end. When I came first to the county, many of the poor people never saw the sum until they came out and sat down at the ends of their cots. But now, there are very few houses without windows to be seen, though there are as many swine as ever. Poor cottars are now dressed like

* The railway has since been made. 
ladies and gentlemen-nothing but silks and parasols. 'Jack's as good as his master,' and sometimes he thinks himself a good deal better. A dreadful place for moneygathering, all coupled with a tremendous thirst for sermons and prayer-meetings. Notwithstanding this, we have scraping and lying all the week through."

None of this prosperity affected Dick. His business was steadily falling off. And yet "the weary siller" must be worked for. He was now getting old, and felt himself unfitted for entering upon any new occupation. Ile would have emigrated, but he hạd not the means. Nor could he remove to any other place, for the same reason. He was bound like a limpet to its rock. But fur his love of nature, it must have been a lonely life that he led. He seems to have had few friends to whom he could communicate his joys or his sorrows. At least he never mentions them in his letters to his sister, in which he mentioned all that he knew, and all that he was doing. The principal person about him was his old housekeeper, Annie Mackay, whose halfHighland, half-Scotch conversations, he sometimes mentions to his sister. Here, for instance, is a specimen :-

"Och hane! I'm thinkin' it's yeersel that's in the starvation countrie, wi' yeer eggs at saxteen pence the dizzen, and yeer coos' butter at twenty pence the new pund! Och a nee, the like o' that's a farlie! Fat gars ye spike that waa, and consither a firlot little when she's muckle? Eh-a? I dinna see yeer mistaaks, and hoo ye read yeer paper upside doun. Fan yeer wark is deen, ye gang oot by an' kill yeersel and no be sorrin 
at the fyre. That's fat ye sud dee, an' if ye dimna, ye kenna fat's the consequence, nor hoo a' study wearies the flesh. Forbye, ye tak cauld, and get giddy in yeer head, loss understandin', and coup ower, an' mistaks, damage things, and brak. Fat wye? Fat sense's that? I dinna see ony intill't.

"I canna see hoo ye see, I canna mak oot hoo ony Christan genlm is to gang oot in mires, brakin stanes amang snaw, and seekin' whistles in a moor hill-side. $\mathrm{Na}$, na; he's fustlin' eneugh in Lonon [this must refer to Sir Roderick Murchison], sittin in a chair toastin' his taes, and lookin at Africa wye two thousin lochs amang mountains. Forbye ye mistak sair a' the warl's wyes, an hoo anither thing says one thing is meant. An' foo, unless yeer astonishmen' is greet, yeer need to spike is little."

Dick seems to have been much amused by the conversation of his housekeeper. She was a very careful woman. She never wasted a farthing's worth of her master's goods. When beggar children came to the door, she was firm in her resistance to their entreaties. "The breed wuna hers, but the maister's." The bairns waited until the maister was at home, and then they had their serving. For Dick was always generous to hungry children. "My kin' maister," said Annie, "was very fond o' bairns that wud be clean an' tidy. Mony a time he gaed a piece ta ony poor bodie that cam to the door."

Another thing that kept Dick poor was his honesty. He gave full weight-full measure and rumning over. He never scrimped any poor person of his bread. His 
quarter-loaf always contained four pounds full; whereas the loaves of many of the other bakers were short by about four ounces. Their two-pound loaves were short by about two ounces. Thus, cheating had the advantage over honesty, of six per cent on every loaf of bread sold. That was a profit by itself; but few people had the means of weighing their bread, to detect the honesty or dishonesty of their baker, and therefore the cheating went on-to Dick's ruin. Yet he never relaxed his principle of giving full weight. "Honesty's the best policy," continued to be his maxim. He felt that it was better to die than be dishonest.

In a letter written to his sister at this disconsolate period of his life, he says :-

"I have not much of a hopeful kind around me, and yet, as I have a sun and moon of my own, I am generally very cheerful. I often take some hearty laughs when no one is near me. I am nearly indifferent to the whole world. But that won't do either. I keep always moving-never indulging in idleness or lying in bed in the morning. Up at four o'clock, or half-past four at latest; sometimes at three o'clock.

"There is a baker here that lies in his bed till seven or eight, and his two apprentices keep knocking at his door until he rises. He goes dabbling on till eight or nine at night. Besides parridge, wife, and bairns, he knows no more. That's not worth living for. People came into the world for something better.

"I am working at my plants perseveringly; and whatever is to be the end, I keep moving. . . . Nor am 
I ignorant that all my toil is vanity, in one sense, and perhaps in every sense. I am indifferent nearly to everything. Hope of any real happiness in this world is out of the question."

And again:-

"I have been poring every spare minute over dried mosses. I have been so engaged during the last month. Not long since, I had the eager curiosity to walk out one night, when I picked up a very nice moss by the light of the moon! You may ask, how could I do that? Thanks be praised, I've got my eyesight, my feelings, and I can grape* too. It was a very frosty night, and hailstones lay thick upon the bog; but I knew the exact spot where the mosses grew. I had taken a look at them some six weeks before, and found them in prime condition. The world was asleep. Mosses, not Moses. I often consult Moses' writings. How fine that is about the scapegoat sent into the wilderness, with the cord about his horns, bearing a burden that he did not feel. Splendid Bible that!

"If any friend asks you about your brother Robert, you may say that he inherits the blessing of Jacob's son. If they inquire which son, you may say the one who was likened to an ass 'stooping down between two burdens' - with this difference, that instead of two, your brother has a score or two of burdens. He knows by sad experience that 'rest is good.' But he is at times so wearied and sore that he cannot find rest. And further, the person who said that "the harder the

* Grape---Search with the hands in the dark. 
work the sweeter the rest,' never toiled hard in his life. But there is nothing for the machine that has been long in use but to keep it going, otherwise it would fall to pieces. So I always keep in motion, though the battle is not half won yet."

One of his troubles was that his eyesight was becoming defective. "You see," he said to his sister, "that I am on the decline-not in bodily strength, for I can walk sixty miles without a rest-but in eyesight. I have to use spectacles with candlelight, either in reading or writing. I am employing my spare time in working at my plants. I have arranged fourteen hundred specimens, but I may say that I have three thousand specimens altogether, because of the varieties."

His sister sent him a new pair of spectacles, bought expressly for him at Edinburgh, but they did not suit his eyes. "It is a sad annoyance to me," he said in reply, "that I cannot read with them-the more especially as I can hardly live without books, and my time for reading is principally in the evening. As it is, I must endure the drawback. Few and scanty are my pleasures; indeed they are such as are usually despised by thoughtless people. I will surely try to live an inoffensive life, though I'm no favourite with anybody. I have a great deal of unknown grief. This world's people have almost left me, and I struggle hard, very hard."

His sister at once sent him a new pair of spectacles, and they suited him better; but he said, "It is rheu- 
matism that has been troubling me, and giving me that dreadful pain in the eyes. . . Y Your petting is not good for me. I've been so long accustomed to rough usage, that your kindness seems quite unnatural. I, have laid my own specks aside, and am trying your pair, but there is no abatement in the rheumatism-not one hair. I pay for reading as dear as ever. It is certainly rather hard that there should be any tax whatever on the means of acquiring knowledge.

"I am pretty indifferent to the thought of growing old, if I could only read as freely as I used to do. Nothing like the natural eyesight. I never wearied then. I did not need to squeeze my eyeballs or my eyelids, to get relief. If the pain were constant, I should be truly miserable. But as yet the infliction merely comes and goes."

In the autumn of 1862, Professor Wyville Thomson, then of Queen's College, Belfast, called upon Mr. Dick at his bakehouse, and had some conversation with him as to the fossil fishes of the Old Red Sandstone. The Professor was introduced by Charles Peach, and was therefore made cordially welcome. After some conversation about fossils, Dick turned to the subject of Botany, and the Professor promised, so far as he could, to furnish him with the specimens of dried plants of which he was still in want. On his return to Belfast, he sent Dick a list of British plants, and asked him to mark those which he required for his herbarium.

Sir Wyville Thomson has favoured us with the following recollection of his visit :- 
"My acquaintance with Robert Dick was very slight, but I was greatly struck with all I saw of him. I had been working at the Old Red beds in Orkney with William Watt, another very remarkable man, somewhat of the same character; and crossing over by Thurso, I spent two or three hours with Dick, whom I knew about through my old friend Peach. I was specially interested at the time in the structure of Coccosteus, and had got some fine specimens in Orkney, with all the outer armour plates capitally preserved; but I remember Dick showing me some curiously preserved examples from beds of a different character near Thurso, which threw a good deal of light upon the form of the cartilaginous part of the skeleton.

"Dick was a singular man-very shy and retiring, and not very easy of access in his bakehouse. Peach had a very great regard for him. He was intelligent, and fairly well read on all matters. One fancy he had was for Egyptian antiquities, and his bakehouse was all over with Egyptian hieroglyphs. He was a good botanist, and a very intelligent geologist. He did not, however, believe in the succession of species, and would never have done for a Darwinian. His firm conviction was, that all living creatures had been on this earth at the same time."

The result of the visit was, that Dick promised to resume his researches into the fossil fish beds near Thurso, and to send the result of his findings to Professor Wyville Thomson at Belfast. Winter was approaching, and the days were shortening. Thus 
some time elapsed before he could further communicate with the Professor. He thus described the result of his labours to his sister:-

"My spare time," he said, "is very limited; and seeking fossil fish in stones at this season (February 9, 1863) is like playing at Blind Man's Buff-all a-groping in the dark; and it is at the same time attended with the severest labour. As yet, I have found nothing extraordinary. I am fairly in for a search amongst the rocks until the first of April. While the weather is cold, I don't mind smashing away with a hammer on the rocks; but when the air grows mild, the toil becomes too much-and all for amusement!"

In the meantime, a letter arrived from Professor Thomson (February 18, 1863) congratulating Dick upon recommencing his labours among the rocks. "I will try to be careful," he said, "but there is great pleasure in change. An old fact looks so fresh when you look at it through a nice new green theory! At all events, I am right glad that you have taken to the old fishes again. I never saw in my life a little set from which such a lot of information could be extracted as from yours. I think I must come north again for a longer look at them.

"You have one specimen which could throw a deal of light upon a question I am working at just now-a dorsal plate of Coccosteus, which has a sort of double appearance, as if there had been a thick plate of cartilage below the bone. I was more taken up at the time with Asterolepis; so I just glanced at it. But 
now, when I am writing about Coccosteus, it comes back to my memory. I do not remember the size of the specimen, but it would be a great favour if you could lend it to me for a few days. I do not know if you ever do such a thing, but it is a common practice among us working men."

"Can you tell me anything new about Coccosteus? All information would be most thankfully received at present. The next set I mean to take up is Asterolepis."

Encouraged by this letter, Dick proceeded with his researches among the Thurso rocks. After the lapse of a month, his sister wrote to him to inquire what new fossils he had found; and he thus (March 10, 1863) described the results of his labours:-

"When I promised," he said, "to look out for specimens for Professor Thomson, I had faint hopes of finding anything. I had overhauled almost every accessible rock from Portskerra to John o' Groat's House; and that too so very patiently, that I knew, or thought I knew, that very little presented itself on the external surface worthy of the toil of digging. I resolved, however, to try the sea-shore. I there noted all the changes that had occurred since the date of my last visit.

"A furious storm had been hammering upon the rocks since then. Storms make havoc of stronger things than ships. What power a stormy sea has! Its incessant thunderings upon the shores often make a new section of the land. It washes away the bitumen, 
and leaves new strata exposed, so that they may be traced in layers, one above the other. I now found many large blocks of rock, which a hundred men could not move, tossed about as a strong man would toss a football.

"As the sea had gone thundering along over" the rocky ledges, the waves had torn up and removed many of the lesser masses, thus exposing to the curious eye numerous fresh surfaces. I ran eagerly to examine them; for there, if anywhere, I knew that I might have a chance of finding fossils. My luck was, however, very ordinary. I found many scales of the size of halfpennies; bits of bones; bits of fins; and little sea-shells. I found, also, bits of plants, hard and black. In one spot, a large stone had been driven along, and by its weight, as it grated on the rocks, had exposed what, to the inexperienced eye, would seem a trifling bit of bone. I saw it, and laughed aloud. I knew it! I knew it, though not more than the breadth of a penny-piece lay exposed! The rest was under the stone.

"I returned home, but not without marking many wonders. On the following day I returned to the stone, with my hammer and chisels. After fully an hour's hard labour, I dug out the bone, and carried it home with me. I afterwards cut it neatly with a saw. It now awaits Professor Thomson. No one can give him such another bone. A truth! I have a few small fishes, fish-heads, plants, shells, and sundry other things, for the Professor, and I expect more; but 'tis awful hard work." 
Dick also gave the following account of Professor Thomson's visit to a geological friend in London: "The Professor very kindly offered to assist me with a few of my desiderata in dried British plants. I thought I would try to get a fossil or two for him in return, before I drew upon his kindness; and this notion sent me with renewed zeal to all my old haunts by the shores.... Since two weeks after New Year's day, I have been working at intervals. My hardihood has been put to a severe enough test. Only think of my hammering at the rocks for fossils in a snowstorm!"

Unfortunately, the fossils which Dick had intended for Professor Thomson were not sent to him. The reason of that omission will be explained in the next chapter. 


\section{CHAPTER XX.}

DICK COMPELLED TO SELL HIS FOSSILS.

AT the very time that Dick was writing the preceding letter to his sister, a circumstance occurred which brought him almost to the verge of ruin.

He had ordered from his flour merchants at Leith twenty-three bags of fine flour. They were shipped by the steamer "Prince Consort" in the month of March 1863. The steamers from Leith to Thurso usually call at Aberdeen and Wick on their way northward. On entering the harbour of Aberdeen, the "Prince Consort" struck the platform, and ran along the North Pier, where the passengers were taken off. It must have been a lubberly affair, as there was no heavy sea on at the time. It was said that the person who steered the ship was half-drunk.

When the passengers were taken off, it was attempted to float away the vessel, but as the tide was ebbing, that could not be done. The sea eventually broke her in two. The water entered the hold; and, though part of the cargo was saved, Dick's flour was thoroughly drenched.**

* The front part of the ship was floated off some weeks after. The hull was got together again. It was patched up and lengthened; but the "Prince Consort" finally came to grief, and was totally wrecked. 
The ship was insured, but Dick's flour was not. Though the bill of lading intimated that the flour was to be delivered in good order- " the act of God, the Queen's enemies, fire, and all and every other dangers and accidents of the seas excepted" - yet it was found difficult to prove that the disaster occurred through the negligence of those who managed the vessel. Those whose goods had been lost or damaged had therefore to sustain the loss. To Dick it was ruinous.

The cost of the flour was only $£ 45$ : 13 : 6 ; but, small though the sum was, Dick had not the money at his command. What was he to do? He had never been in debt in his life. And yet, not only must this debt be paid for, but he must order more flour in order to carry on his business. He had been slowly going to ruin for years past. He had lost $£ 120$ of his former savings; and now, to use his own words, the loss of $£ 45$ made him "next thing to a beggar." His only property consisted in his books, his collection of fossil fishes, his botanical specimens, his slender stock of furniture, his old-fashioned clothes, and his little store of linen. These were of little value. They could not be sold in time to save him. He must turn to some one else. Then lie bethought him of his affectionate, generous-hearted sister. She had offered him money a few years before, which he had refused, because "coddling and nursing was about the worst treatment imaginable."

But alas! the time had come when he could no longer refuse her generous offer. He wrote to her, pouring out his griefs, and telling her how he had been reduced almost to the brink of ruin. 
"Have you still," he asked, "that spare money? Would you be willing to lend it to me in hope of getting it back again? Should you wish it, I would pay you interest for it. I have long felt the necessity of getting away out of this miserable place. There is no trade, and the risk is very great. I have had a sore struggle, and have often been sadly grieved; but this is the saddest ill that has ever come to me. . . . I am injured for ever. I'll never make an extra farthing by my trade here. The bakers are in swarms now. I am old, and my strength and sight fail me. Before, I had hardships quite enough; but now, this crowns everything. I am stupid with grief."

Dick's sister earmestly sympathised with him. She told him to cheer up-to put his shoulder again to the wheel, and that all might yet go well with him. She sent him $\mathfrak{£ 2 0}$ of her spare money. She did so at considerable sacrifice, as she required the money at that time for special purposes. But she could not stand the piteous entreaties of her brother, and sacrificed her own requirements for his good.

Dick plucked up heart again. He replied to his sister: "I am not easily put down. I am neither inactive nor desponding. I am trying a way of recovering my loss. Your brother Pobert is the most active and laborious person in the county, and could not live in idleness for one week. He does not entertain a single thought of being beat."

The "way of recovering his loss," to which Dick alluded, was by selling his fossils. He had now a very 
fine collection; but when such things are offered in the market, they are likely to bring very little indeed. Still, he was of opinion that if his collection was offered to some scientific man, he might be able to realise enough to pay his debts.

One of Dick's geological friends was Mr. John Miller, F.G.S., a gentleman of independent property. He belonged to Thurso, but lived for the most part in London. He had a great respect for Dick, and took a deep interest in his fossil researches. When at Thurso, Mr. Miller was a frequent visitor at the bakehouse, and had many keen discussions with Robert Dick and Charles Peach about geological subjects. He was himself a collector, and employed a Mr. Budge to obtain for him new specimens of fossil fishes. He often consulted Dick as to their interest and value.

When the thought occurred to Dick of selling his fossils to Mr. Miller-knowing that he was buying them from Budge--he addressed to him the following letter :-

"Some years since you saw that I was distressed, and you offered to relieve me. I put your proffered kindness aside. Since then you have had many opportunities of knowing and seeing me; and I think you will allow that anything like complaining was very far from me. A recent event, however, has ruined me. The 'Prince Consort,' on attempting to enter Aberdeen Harbour, has become a total wreck. I had flour on her, uninsured, to the amount of $£ 45: 13: 6$.

"Enclosed is a note to Sir Roderick Murchison, stating the matter, and promising to send him every 
Old Red fossil in my possession, if he would in pity undertake to do anything among the London geologists by way of making up my loss. Will you in kindness hand my note to him in a quiet way, and I will be ever grateful to you? If you dislike handing my note to Sir Roderick, put it in the fire, and also this one to yourself."

We have not Mr. Miller's reply to Dick's letter. Very likely it may have been intended to cheer him up. At all events it seems to have contained some reference to Dick's "independence," for here is Dick's reply, 27th March 1863 :-

"It is all very good to talk to me about 'independence.' I have laboured among flour bags for the last thirty-eight years, but I never yet knew an empty bag to stand upright.

"An honest well-meaning man once kept his horse on short allowance, and boasted that he had brought him to live on a straw a day. But when he had accomplished his object, the horse died.

"A very kind and a very discerning public have, for the last eighteen years, set me down as independent, and fed me with chopped straw; and now those drunken blackguards of the steamer have ruined me. I am a beggar, not in word, but in fact.

"Previous to writing to you, I applied to my sister at Haddington. She at one time offered me £48. I would not take the money. I thought that she might still have it. She wrote at once, saying that she had it yet, but was about to use it. I told her never to mind 
me, and just to use it in the way intended. She replied again, and sent me $£ 20$.

"The steamer people have sent me twelve bags, out of twenty-three bags of my flour. I have laboured hard and sifted it out, and made out six bags of spoilt flour! With my sister’s $£ 20$, and with what the flour may do, and perhaps other resources, I will try and manage to pay my bill.

"You will please to give orders to the National Bank accordingly. Reverse your order.* I have not gone to the bank, and do not intend to go on the errand you speak of.

"As to my relations with Sir Roderick Murchison, I am already his debtor for two hundred dried plants, and rather than be turned out on the wide world, I would not hesitate one moment in being indebted to his goodness still further."

He followed this letter with another written on the next day:-

"On trial," he said, "I find that the flour saved, after much labour, is mixed with sand; consequently it will have to go for little or nothing.

"In my last to you, I thought that I would get on without troubling any one; but now I find it all hopeless.

"I have written to Sir Roderick Murchison offering to sell my fossils. I have asked his permission to send

* We infer from this, that Mr. Miller had directed the National Bank to pay Dick a certain sum on his account. The italics are Dick's. 
them up to Jermyn Street Museum, that he might give for them whatever he thinks them worth.

"Surely there is no degradation in this idea* It was altogether out of the question to allow the amount of my loss to fall upon you. No! I will not do that. But if you put in a good word for me with Sir Roderick about these fossils, I shall feel grateful to you.

"The fossils are not many, but they are such as Sir Roderick has not in his Museum.

"P.S.-If Sir Roderick Murchison declines to purchase my fossils, I'll not be beat, but will offer them to some other person."

At last the matter was pleasantly settled. Mr. Miller at once agreed to purchase the fossils, and sent

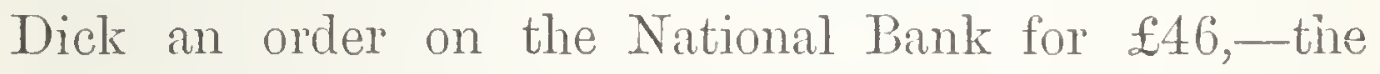
amount of his loss by the shipwrecked flour. Dick cordially acknowledged the receipt of Mr. Miller's letter :-

"I thank you most sincerely. I have to-day (4th April) received a note from Sir Roderick Murchison. He will take the fossils; but I have settled it in my mind to give them to you. I am afraid that I grieved you by refusing your gift, but I could not, poor as I am, take so much money for nothing. I will give all my fossils to you-every one of them-shells of the boulder clay and all. There are two or three which Hugh

* Sir Roderick had asked Dick sereral years before to sell some of his rarer fossils to the Museum, but Dick preferred making a present. of them. 
Miller gave me, and these I will add to my own collection of fossils. I will also give you all those which I had got for Professor Thomson, and my blessing along with them.

"Of course $£ 46$ is too much for them; but the fossils are worth-what they are worth; and I must just be contented to stand indebted to your frieudship for the rest. I will label on the fossils the localities in which they were found, and also pack them carefully.

"I am to write to Sir Roderick by this same post, telling him that you had heard of my distress, that you had made a most liberal offer to me for the fossils, and that I had given them to you. I know-at least I trust-that Sir Roderick will see meet not to be offended at me for giving you the preference. Sir Roderick will get plenty, and so will you. But one thing you know, that some of my fossils are altogether rare, and not in the possession of any other person."

And thus ended the sale of Dick's fossils. He parted with them with a heavy heart. But he was now enabled to pay his bill for the lost flour, which he did on the 29th of April following. How he regretted the loss of his fossils may be inferred from a letter to his brother-in-law:- "Unhappily," he said, "I have now no fossils. I have given them all away. Alas! how often has my heart beat proudly, when looking over the figures of jaws in Duff's and Dr. Buckland's books, and saying, 'O yes, these are very fine, but humble as I am, I have finer than either.' But that is over, and they are all away. They exist only in remembrance, and I never hope to find the like again." 
Again he felt his business falling off. Unfortunately, he had tried to make bread of the sifted flour saved from the wreck; but the bread was not good, and more customers left him. "They might have borne with me," he said, "a little longer, if they had only known of my suffering and distress." Afterwards, he said, "If I had only half as much work as I could do, I should be the happiest of men. I have more biscuit beside me than I shall be able to sell in three months. I would toil willingly, but all is overdone here. It is very difficult to get work at all. He is a happy man who can make his living. Shoals of masons and house-wrights are leaving here by steamer.

"Men are failing rapidly. One is said to have failed for $£ 3000$. He hasn’t preached according to his stipend. You know the story. An elder went to his minister, and said, 'that his preaching was rather poor; that's what people said.' ' Of what do they complain?' asked the minister. 'Weel, sir, they're saying that ye dinna preach half weel.' 'So,' said the minister, 'but ye dinna consider that ye dinna pay half weel. I preach according to my stipend. Pay me better, and I'll preach better!' And so, had the people bought better, the merchant would have sold better, and not a breath would nave been heard about his failure."

Though Dick said that his customers were leaving him, and that he was thought less of than ever, there was still some comfort left him. "Nobody heeds me," he said; "and yet Nature is as kindly as ever." The spring was approaching. Fine balmy days wooed him 
to the fields, or led him along the sea-shore. He watched nature with the eye of a lover. He longed for the coming of spring; and when she came he was unspeakably glad. He looked anxiously for every favourite plant, and knew it at once as it put its first stem above the ground.

The spring was later in 1863. At the end of April the fertile stems of the common Field Horsetail were not yet above ground. He had seen only one rumpled straggler. Neither Drummond's Horsetail, nor the Wood Horsetail, had made their appearance. It was not until about the middle of May that he found them above ground,-excepting Drummond's Horsetail, which was always late.

"I went out last Sabbath morning;" he said, "up the river-side, and found the common Field Horsetail and Wood Horsetail. The Water Horsetail was by the riverside. The prevailing flowers are dog-violets and yellow primroses. I found about six specimens of a rare plant peculiar to the north. It is Ajuga pyramidalis-a plant I have sent alive, as well as dried, to the south. It is a great prize with botanists. Of course, I look on them now with very different feelings from what I once did. I found also the early Purple Orchis by sixes and sevens. Also a species of chickweed which I never saw before. It is a larger and showy species. No other flowers have come up as yet. But they will come. And when they come, short will be their stay, and all will be again desolate."

A few days later, he again goes up the river-side, and found and plucked numerous specimens of the far-famed 
grass-Hierochloë borealis. By this time Dick had received communications from botanists in nearly every part of the country, asking for dried specimens of the grass. He also went to the cliffs on Dunnet Head, to his ferneries on Beu Dorery and the Reay hills, to see how the ferns were growing that he had planted-ferns that would still be growing when he and his friend Peach "were both out of time."

"I have discovered," he says one day, "another plant wonder! Some time ago I found a new daisy. I have now found another. It has twenty-four little heads, and the stalks are longer than the other. I sought all over the grass field on which it grew, and could not find another. I never read of such a daisy being found wild. A daisy with thirteen heads, and another with twentyfour heads, are most extraordinary. But 'little things are great to little minds."

To his brother-in-law he said:- "So you have been amongst gardeners, and found a daisy. Still, the wild one is, I think much finer. It is tall, and being single, it makes a more natural show. I have hastily pencilled it off [giving a drawing of the wild daisy]. I could have done it much better,- - only it is Saturday afternoon, and I am busy.

"The daisy is a great favourite with the poets; Burns speaks of it as the 'wee, modest, crimson-tipped flower.' Another says of it, "the bright flower, whose home is everywhere.' Another-

" 'The rose has but a summer' reign,

The daisy never dies.' 
And still another :-

" 'Not worlds on worlds, in phalanx deep

Need we, to prove a God is here;

The daisy, fresh from winter's sleep,

Tells of His Power in lines as clear.'"

As far on as the month of June, the weather was cold and wet. There was a good deal of hail, and one day of almost continuous snow. It is true, the snow melted as it fell, and did no other harm than giving the grass a brownish colour; though the country folks said the distant hills were covered with snow.

Dick went to Loch Duran, some seven miles off, to see the Bullrush, rather a rare plant in the far north; and besides the Lake Bullrush he found a much rarer plant, the Lapland Reed. He could find the plant nowhere else. Six miles inland he also found the Baltic Rush. "How it got there," he said, "I cannot make out."

He was recommended to try his hand among the marine plants. "I have little doubt," he observed, "that something new might be discovered among the weeds along the sea-shore. Solomon says, 'All things are full of labour.' But I'm ower auld for the labour, and as for the honour, if I get a splitting headache and a sweating cough for my pains whilst dabbling in a saltwater pool, perhaps the cost to me would be greater than the honour. The poor animal is overladen already, and to put on more weight would probably squeeze the life out of him altogether."

"In fact," he says to Mr. John Miller, "I fear that in pursuing researches among the rocks I have not been 
half cautious; for during June I have been suffering severely from rheumatism,-- to an extent greater than ever I did before. 'The vengeance' has got hold of both my feet,- - so much so that I have a difficulty in walking. That, you may be sure, was gloomy for me. I grumbled to be compelled to walk slow, especially when the spirit within said, Forward."

And yet, when sufficiently well, Dick immediately went to the fields again to gather ferns, grasses, plants, and wild roses. One day he says to his brother-in-law, "I have had a ramble sixteen miles out and sixteen miles home again for a small fern not so long as your little finger. I would not have gone so far, but that the fern would not come to me. I had another ramble twelve miles away and twelve miles home again, and all for nothing. The plant I went to get was not growing for want of moisture."

Dick had many applications for native roses. He sent a number of them to Professor Babington of Cambridge; but he thought that the professor's opinion as to the species to which they belonged was not quite correct. Writing to a friend he said, "The genus Rosa is a difficult one, even for the most experienced botanist. It is hardly possible to tell the different species by their leaves alone. Their fruit is a far better test. For example, the leaves of the spiny or thorny rose may be found of various sizes-from an eighth of an inch to more than an inch long. They differ so much in their hairiness and smoothness that it would almost puzzle a conjuror to define which was which. Some years since 
I sent a packet of dry roses and leaves to Professor Balfour, who sent them to Professor Babington in England. The latter gave the best verdict he could, and yet $I$ have no faith in it. For example, he told me that he believed one of them to be Rosa involuta. Now, Rosa involuta is found in the Western Isles, and a stranger might conclude readily enough that the plant grew in our neighbourhood. I have ever since been watching the bush from which I took the specimen; but I camnot form any other opinion than that it is a variety only of the Rosa spinosissima, or the Thorny Rose. The leaves of the said bush might pass for the leaves of Rosa involuta, but the fruit will not. The fruit is invariably the fruit of the Thorny Rose."

In September 1863, Dick received a letter from Professor Owen, stating that he had been informed that a large sperm whale had been cast ashore near Thurso, and that, as he should like to secure the bones, he would feel obliged to Mr. Dick if he would make the necessary inquiries about the nature of the whale-whether it was a sperm whale or not. He added that Sir Roderick Murchison had informed him that Mr. Dick was the most likely man in Thurso to help him on the occasion.

It seems that the whale was cast ashore at Sandside, about thirteen miles from Thurso. Dick worked all night with the object of starting on foot next morning. But at two o'clock it began to rain, and it rained continuously for about a fortnight. What with his pains and his rheumatism, he could scarcely go out of doors during the interval. "Even if I went there," he said, 
"it would only have been-to guess. But I gathered all the information I could get about the whale, and sent it to Professor Owen."

Dick still kept up a considerable correspondence, though it was for the most part forced upon him. He was indisposed, amidst his troubles, to open new correspondence; though those who had corresponded with him once, would not allow him to forget them: his letters were so interesting, humorous, and instructive. He was often invited to pay visits far from home; but that was, of course, impossible. Few of his correspondents knew of his poverty. Very likely, many of them thought him to be a man of independent position. Mr. Notcutt of Cheltenham thought that Dick wished the correspondence with him to cease. But he wrote to him again and again, until he replied. "I shall ever feel grateful to you," said Mr. Notcutt, "for the noble series of Old Red fossils which, through your liberality, I possess. I append a list of most of the things (dried flowering plants) which I have for you." And at length Dick was thawed into continuing the correspondence. Of course Mr. Notcutt knew nothing of the pecuniary struggles that Dick was then passing through.

Numerous requests were made to Dick for exchanges of plants and fossils. Amongst his correspondence we find letters from Dr. L. Lindsay, lichenologist, Perth; Mr. John Sim, botanist, Perth; Mr. Roy, botanist, Aberdeen; Mr. Alfred Bell, Bloomsbury Street, London; Mr. John Backhouse, York; Mr. Henry Coghill, Liverpool; Mr. George Henslow, son of Professor Henslow; 
and from Mr. Tarrison of the Registrar-General's Office, Melbourne. The principal applications made to him were for fossils from the Old Red Sandstone, and for specimens of the Hierochloë borealis which Dick had discovered so many years before on the banks of the river Thurso. Mr. Pringle of the Farmer's Gazette, Dublin, in acknowledging the receipt of a specimen, addressed Dick in the following letter:-

"I gave the specimens of the Holy Grass to Dr. Moore of the Botanic Gardens. He expressed himself much gratified with the same, and stated that he would like to correspond with you. I send by book-post a copy of his Notes of a Botanical Tour in Norway and Sweden, which will likely interest you. I must repent what I said to you-that I think it is a great pity, nay more, a shame, that a man of your abilities and research should be buried alive, as you are and have been. Why not come out as an author on those subjects with which you are so conversant? I hope yet to see Robert Dick's name taking its proper place among the list of British scientific men - far above the names of some who occupy a large share of public attention, but whose chief claim to notoriety consists in an unbounded command of cheek, and of a still more unenviable gift of the gab."

But it was too late for Robert Dick to give his thoughts to the world in writing. For one thing, he was too modest. He was about the last person to wish to see his name in print. He was always complaining of the smallness of his knowledge, even about subjects 
that he had studied the most. "The more I know," he said, "the more I feel my ignorance. Knowledge seems to retreat before me." He often quoted the words of Athena's wisest son-" The most I know is, nothing can be known." And yet he said, "There is a satisfaction in getting on in knowledge, which those only can imagine who have risen early in searching for it."

He still continued to write verses, probably as a relief from business troubles. Mir. Peach says that he wrote verses down to the end of his life. The following are extracted from some verses written in 1863, when in the midst of his sorrow and poverty. The verses commence, "O waft me o'er the deep blue sea!" and proceed to the seventh stanza, which thus begins:-

"O waft me o'er, and let me roam

Her untilled plains, her fertile soil, Where weary wanderers find a home,

And live by honest, manly toil!

By manly toil they rear a home-

Nor curst with want, nor crushed by care;

Nor grasping greed, nor grinding down,

Nor sad and weary struggle there.

"O waft me o'er! O waft me o'er!

In yon fair land there's peace and rest, And toiling-room for thousands more,

With blissful Hope to soothe the breast. With grief, with care, by sorrows prest,

Of fruitless toil, my heart is sick.

O endless dreams, in horrors drest, Of cruel want, when old and weak! 
"O waft me o'er! O waft me o'er!

Yon ship is strong; the sea is still;

Nor care I though a tempest roar,

And every billow rolls a hill!

Let swelling sea-waves roar their fill,

And dash till crested white with foam,

'Tis sweet as murmuring mountain rill,

To soothe a weary spirit Home."

During his troubles Dick was a sleepless man. He wandered up and down the little town at night, looking in at the little burying-ground of St. Peter's, where the fathers of Thurso lay buried. The town was asleep. Not a footstep was to be heard, save those of the sleepless man plodding round the graveyard, and from thence to his neighbouring bakehouse in Wilson's Lane. Night was always a time of thought for Dick. "It is so pleasant," he says in one of his letters, "getting up at nights to see the stars. Last night was beautiful, and the moon was a great pleasure. It is impossible, when looking at it, to prevent oneself falling into a dream of a far better world than ours."

"Do you know," he said to his brother-in-law, " that I am a firm believer in the umseen world? Millions of spiritual creatures walk the earth unseen, both when we wake and when we sleep. I have no doubt that they exercise a watching care over us, and often warn us of coming evil. Since my sister Jane died, I never dreamt of this but once. What people think often about, they commonly dream of. On that occasion, my sister, I thought, came to me, clothed from head to foot with roses! I smiled when I saw her, with 
pleasure, and awoke with the reflection that my sister, knowing my taste for flowers, had chosen that way of expressing her happiness.... You may smile at this, and set it down as Robert's silly superstition; but of one thing you may be assured, that unseen beings care for you, and that nothing can happen to you without the permission of our heavenly Father."

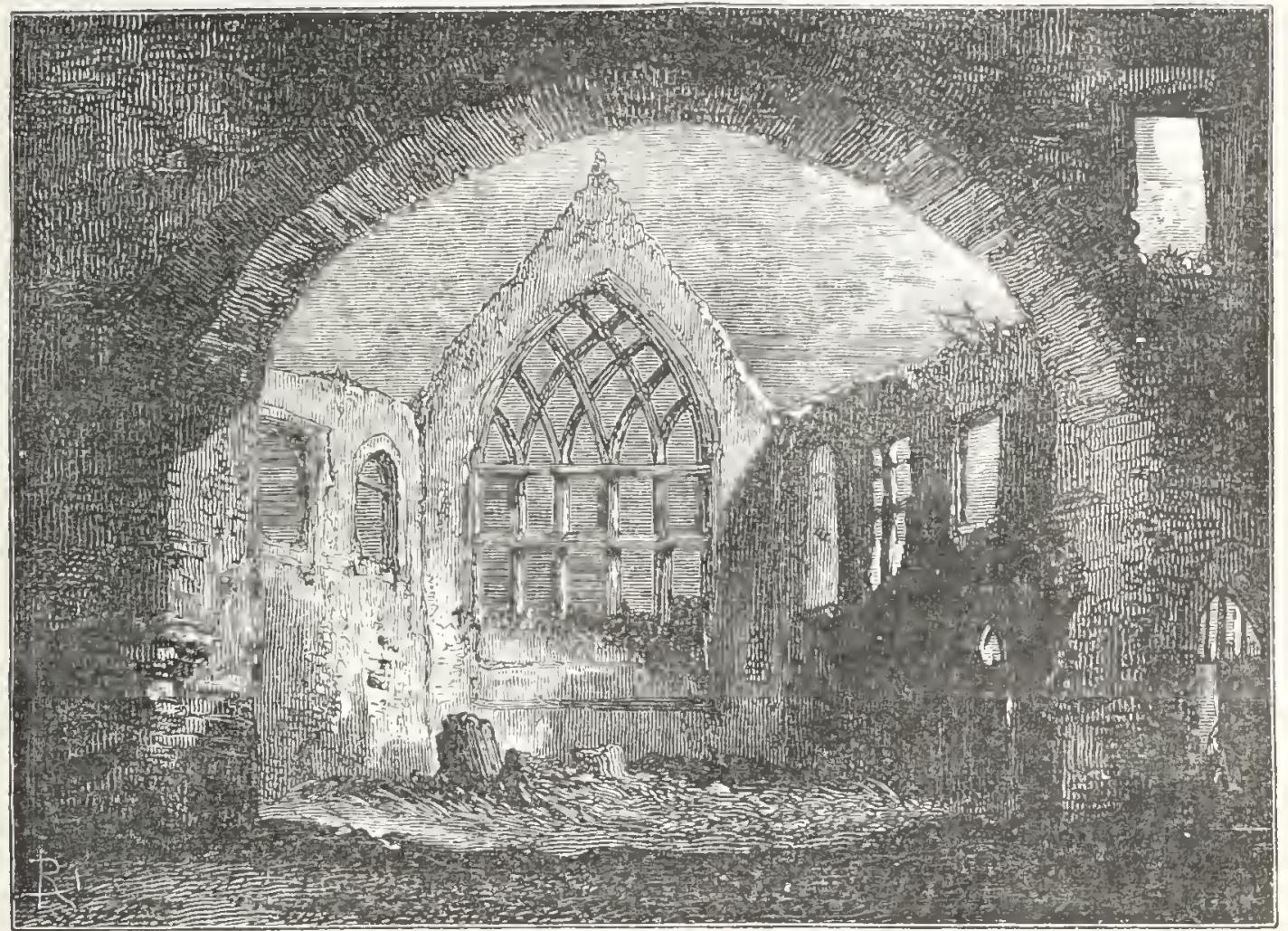

RUINS OF ST. PETER'S, THURSO. 


\section{CHAPTER XXI.}

DICK RECOMIIENCES A COLLECTION OF FOSSILS.

"I An not beat yet!" said Dick. "I have resolution, will, and ability to work. Let me try again."

His flour was wrecked on the 9th of March. A few months later (May 18th), we find him by the seashore, about six miles east of Thurso, where he had found his last fossil fish. He had to a certain extent got rid of his rheumatism. "I have got the use of my feet," he says, "and am blest in comparison. It was terrible to be hampered like a hen with a string round its leg.

"Though I did not discover much, yet I am surprised that I found so much. I have dug out of the rocks what no one else ever got out of them. It is cheerless, cold work. Lonely work too. But no good work can be done in company."

He next visited a hill near Thurso, from two to three hundred feet high, where at one spot the fossil fish lie by the score, fish over fish, packed like herrings in a barrel. With the insight of the poet, he saw the sepulchres of the past beneath his feet.

"Tell me, thou dnst beneath my feet,

Thou dust that once had breath,-Tell me how many mortals meet

In this small hill of death. 
"By wafting winds and flooding rains,

From ocean, earth, and sky,

Collected here, the frail remains

Of slumbering millions lie.

"Like me, thou elder-born of clay

Enjoyed the cheerful light;

Bore the brief burden of a day,

And went to rest at night." *

"For my own part," he says, "I would never have sought after these fish, did not a feeling of wondrous astonishment take possession of me. Every time I think of them, I can scarcely understand how they are there." And again, "I often feel very much puzzled about those dead fish. I mean as to whether they lived before or since the creation and fall of man. Did Death exist before man's disobedience? . . . One thing is certain : the present habitable world is a graveyard!"

The fossil fish heretofore discovered had for the most part been broken. Bucklers, scales, bits of fish of various kinds, had been found fossilised, and from these drawings had been made; but parts of the drawings were guess-work. Dick determined to find, if he could, an entire fossil fish, and proceeded to make many searches for it. He thus picturesquely describes one of his journeys for this purpose :-

"On Monday I made a large day's work (that is, of bread and biscuit making and baking), intending to set out early on Thursday morning. The morning was rainy, but by eleven o'clock I was able to set out on 
my two hour's' walk to the neighbouring hill-top. After a brief interval I cleared off the rubbish, and began to turn up dead fish. They were all rotten. Many thousands had died and been buried here a long time ago. The mud had choked them, and buried up their

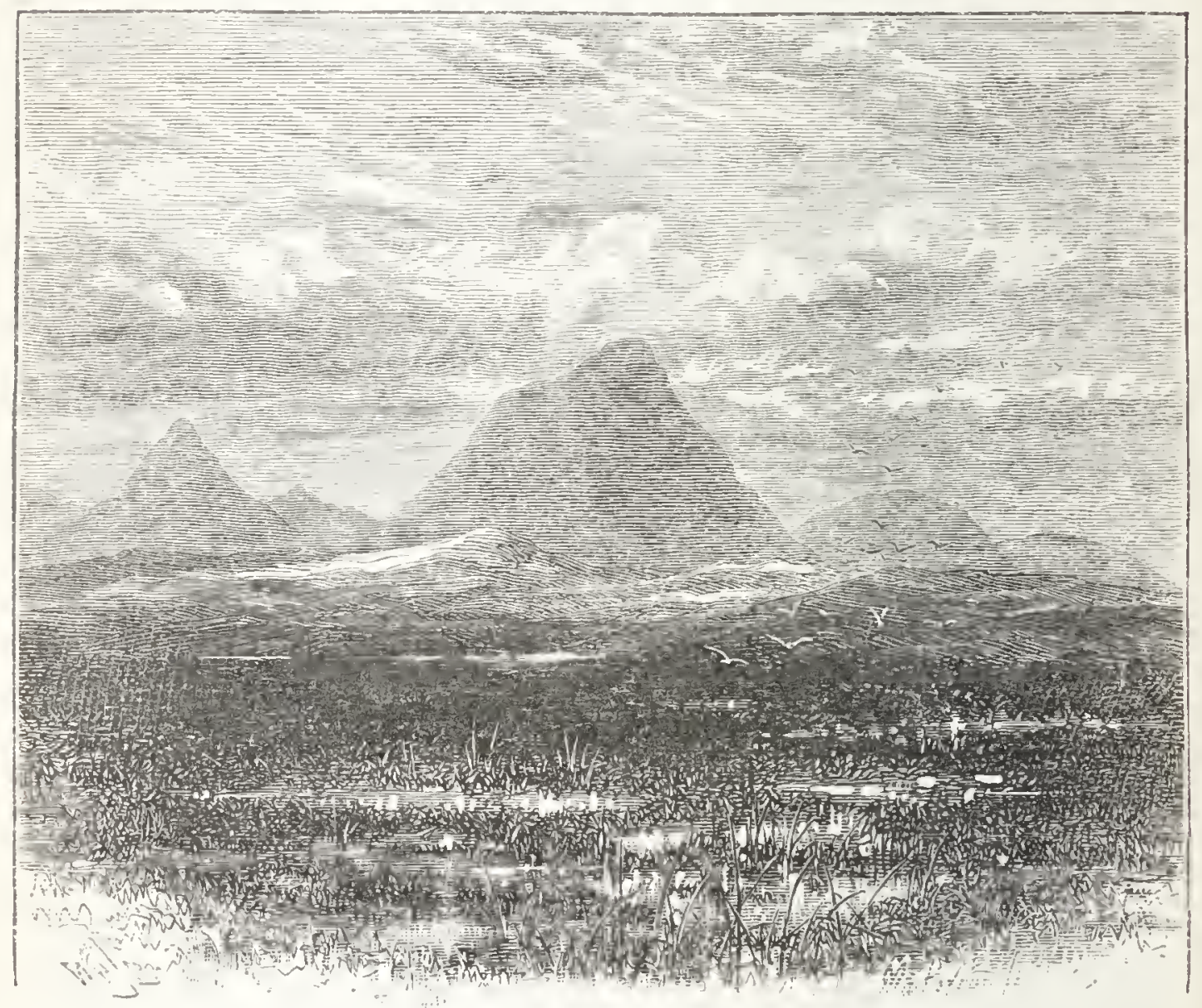

DISTANT VIEW OF MORVEN AND MAIDEN PAP.

bodies, fish over fish, in whole myriads. Thousands of thousands must have died at the same time. "This platform of death, as Hugh Miller phrases it, extends for many miles.

"Standing upright and looking round, I can see Weydale some miles away; and there is reason to believe that the beds of fish on this hill and Weydale 
are one and the same. It is true, they have been cut across, and the rocks have been disturbed and lifted up -twisted, broken, bent, and what not-in a thousand different ways; and yet I have no doubt they were once continuous. What numbers! I turned them up, rotten, by twos and threes. . .

"I stood up to rest me, and looked around. It was a beautiful day. The sun was shining brightly. Far south I saw Skerry Ben and Morven. Skerry Ben had hardly any snow wreaths on it, and thin vapour seemed to be rolling away from its summit. Looking over all the intervening space, the country seemed very bare. Nothing broke the uniformity of the prospect until the eye rested on the Dorery Hills, and these seemed black and uninteresting.

"Seaward, all was in motion. The Orkney hills on the north were capped by clouds, which rolled along their summits. Not very far west frowned a dark precipice, at least 200 feet high, at whose base the sea waves were toiling and grinding.

"I went to work again,-raising up thin layers of rock, and turning out rotten fish; but nothing of any worth. As I got down the stone got firmer, and the fish were sounder. But where was my dream? I had fancied that I should find the big fossil. I knew that part of it-indeed two parts of it-were found in this neighbourhood; and I thought that perhaps I might alight on a whole one. But no! There was no fossil for me, such as I wanted; and having raised up a stone with three tolerably good fishes on it, I thought that I had better wend my way home." 
Disappointed but not baffled, Dick continued his researches. "On Monday morning, after my work was over, I walked out some two miles to a quarry by the side of the road, where I knew fish bones abounded. It is not a regular quarry, but a hole out of which stone for road-metal had been taken.

"'Imperious Cxesar, dead and turned to clay, Might stop a hole to keep the wind away.'

Who knows? One thing is certain-it is so with the poor fish. Nearly all the houses in Thurso are built of dead fish. All the ploughed fields are fields of the dead. The living plants feed on the dead, and so it is everywhere. Was it ever otherwise? Once I believed in a world without death-hideous death. But it is a sad thought that death exists over all creation. Some, however, say that death is necessary and a blessing; because, without it, there could be no progress. Alas! is death then a necessity?

"I went to the quarry by the road-side, and was grubbing away for old bones, to the no small amusement of the passers-by. No doubt they thought me mad. Some looked curious; some looked pitiful. At last one of them came and planted himself opposite me.

"'Hae ye lost onything there?' 'No.' 'Then what are ye seeking?' 'Auld banes.' 'Auld banes?' 'Ay, auld fish-banes.' ' $O$, there's none o' them there: I'm the man that quarried the hole: there's nae fishbanes there.' 'If ye like to believe me, gudeman, the banes are abundant.' 'Na!' 'Oll yes; it's an auld burying-ground.' 'Th!' 'Yes; look at that.' 
"At this the man came running up the brae, and I handed him a stone all covered with scales. 'Eh!' said he, and then he took the stone. He looked at it. 'Weel,' he at length observed, 'that's trash - nothing but trash.' 'It's an auld burying-ground, I assure ye,' said I; 'it's of great antiquity.' He threw down the stone and walked away solemnly. I have no doubt he thought me crazy-perhaps something worse.

"I got so many heads, jaws, Coccosteus bones, and such like, that I nearly killed myself in carrying home the stones. My arms are still sore, and my breast is sore. For all that, I would carry as heavy a load tomorrow."

A few days later he says:-

"I have again been to the limestone quarry on the hill, and have brought thence one fossil fish and some half-dozen of broken bits of other fossils, and only one moss from the waterfall.

I half filled my hat with the Fern Blechnum boreale, or Northern Hard Fern, which I found growing in beauty in sheltered spots.

"I saw tree stumps in peat banks, molehills, muirfowl, and lapwings, - and snow wreaths on hill-sides and around lochs. I had a long, long, beautiful walk.

"Hugh Miller, to his dying day, insisted that nothing organic lived in the north of Scotland previous to the deposition of the Old Red eonglomerate. The Old Red conglomerate was to him the fossiliferous base in the north. He knew and acknowlediged the Silurians of the south of Scotland; but he argued that Durness limestone was of 
Old Red age. Professor Nicol said it was of mountain limestone. Sir Roderick Murchison has classed it Silurian.

"When Hugh Miller was in Orkney he saw the Old Red conglomerate at Stromness, and followed the fossiliferous rocks along the sea-shnre upwards, until he found a fossil bone, which he termed the "Nail," and he counted how many feet this "nail" was above the old Red conglomerate. He considered this "nail" the oldest bone in Scotland. So he said. He knew of none older at that time. The Durness fossils being all shells and molluscous animal remains, Hugh probably thought that nothing of a bony nature existed in Scotland older than his Stromness "nail." And this bone was a fish remain, many hundred feet above the Old conglomerate.

"But what would Hugh have thought of fish underlying Old Red conglomerate? Fish remains older than conglomerate? Alas, poor Hugh! such is actually the case. The other day I turned up and brought home with me to Thurso the remains of fish that had lain buried below the Old Red conglomerate! But Hugh had seen the 'Base' in many places, and preferred retaining the old opinion.

"I believe the opinon entertained by our highest geologists is, that there is Old Red conglomerate of many ages; whereas Hugh Miller considered it as of one age-one great formation. He says that it extends from the Grampians to Orkney, and from Peterhead to the Western Isles; that it lies in a continuous stratum of variable thickness; and that no fish lived then in what is now Scotland. A great mistake! 
"I have found pieces of clay slate in the Old Red conglomerate; that is, the slate was in existence before the other was formed.

"Those fish I found the other day lived before the old Red conglomerate was wholly made. A bed with rolled granite ground down into sandy gravel overlies a bed of limestone, and the limestone deposit overlies a bed of limy clay, which contains the fish remains.

"It is a beautiful spot where the dead fish lie buried. All is quiet and still. No sound of any kind, but the wind whistling along the heather. In summer time the royal eagle comes to build beside the waterfall, and to prey upon the muirfowl. Death's doings are still about us, and who knows how long it is since they first began?"

A few days later, he says:- "Some time ago, one of the flagmen showed me a fossil which he did not understand. It was a fine one, and only your humble servant knew what it was. I had, twenty years ago, furnished Hugh Miller with such a fossil, and this was the only instance of another turning up anywhere. This was found in the quarries. I sent word to London, and Mr. John Miller bought it. It gave me pleasure to find Hugh's word corroborated. I have not the least doubt that the entire fish will some day turn up, and then it will be seen who was speaking truth."

Dick also searched the rocks at Murkle Bay, where he had found the big fossil buckler. One day he discovered a rather large bone sticking out of the mass. He went at it with his hammer and chisel. He laboured 
for nearly four hours, and then he left it to return again on the following day. To get it out, required several weeks of hammering and chiseling. He had to go to the bottom of the bone to get it out. He did not mind the amount of labour he gave to a fossil, provided he could get it out whole. He once worked at a particular bone for six months. The fossil, on this occasion, was a prize. It measured one foot two inches long, by six inches across.

"At the same time," he said, "I don't neglect my employment. Whether I get out the bone or not, I always make sure of doing my day's work first. I nerer yet trifled a moment for anything. If I want playing at fossils, I merely rob myself of my rest and sleep.

"It is now twenty years in March last (his letter was dated 7th September 1863) since I found a bone so large. And not only have I got so large a bone, but what is a step in advance, something new. . . I have sawn the four sides of the stem, and also taken four inches off the bottom thickness. It is now portable. It can be lifted. Before, it could not be moved without taking with you the immense rock in which it was imbedded.

"It is very odd, that in twenty years I have never found an entire fish. At that time I found two of those fishes, but much broken up. Hugh Miller was satisfied that they were the same as he figured in his book. That idea is doubted now by some London men; and here am I laughing at them and wishing that I could find another fossil fish. Amen! may it come soon." 
Two months ]ater he wrote to his brother-in-law :-

"Perhaps you are thinking that I am busy with those bones on the rocks here; but no! the last bone nearly killed me with fatigue and cold. Besides, I cut my hands, and cut my little finger. Of all the labour I ever tried, there is none like digging on the sea-shorecrouching down on one's knees in a hole, bothered with incoming water, and hammering, and picking, and sawing all the while.

"I have got another curious evidence about that fish, which Hugh Miller never saw. Perhaps he dreamt of it. Most certainly he spoke of a time when the bone which he figured would yet be found.

"After all, there will be no satisfying of those men's doubts, until a whole fossil fish, of that particular kina', turns up. I wish I was the lucky finder of it; then I would laugh !

"Indeed, I don't think I understand the fossil myself. How little do we really know; above all, how little do we know accurately! No entire fish has turned up yet; only broken and disjointed pieces. And such pieces! Bones a foot and four inches across. No one can credit it, unless he sees them. Perhaps I'll yet turn up a whole fish!. . Similar bones to these two bones beside me no human eye ever looked upon until August 1863."

Dick continued at his digging. On the 31st October he writes:- "During the bypast week I have been unexpectedly no less than three different times digging amongst those dead fish and plants in the rocks on the 
shores here. I had no intention of being there more than once; but once at it, I could not get off without suffering a great deal. . . . I can walk for miles upon miles over these dead fish, almost without drawing a sigh! Once I felt differently. I was then lost in wonder and mute astonishment. Now it is quite an everyday affair. If I think at all, I think they are part of the still existing creation.

"Many years ago, when Hugh Miller was alive and in his glory, I had seen in a pool of water, bound fast in the rock, a bone. It was a broken bone. The pool was connected with three other pools of salt water. To get at the bone at the bottom of the pool it was necessary to throw out the water from all the pools. I boggled at the labour. . . On Monday last I got up at midnight, toiled at my work, and was off by midday to the sea-shore. After half an hour's walking, I arrived at the place, took off my hat, my coat, my neckcloth, tucked up my sleeves, and with the assistance of a flat stone I threw out the water. This took me an hour's incessant work.

"Well, I cut out the fossil bone, and another fragment of bone. Strange to tell, under that bone I found indications of another bone. I toiled away and cleared off the stone-saw that the bone was a good bone, and hoped that it was something new. Returned to it a second day; cut deep round the bone; got wearied out; tried to force it up, and broke my pick handle.

"I returned to it two days after, and spent about an 
hour in throwing out the salt water. I was awfully tired. I had to go down upon my knees on the hard stone, and was bothered with the salt water, and the wind and rain too. Well, I dug, and dug, and dug, and at last the stone and the bone rose up of themselves. I could hardly convey them home. I was tired and sore; but I am as well as ever again."

He still went on digging among the rocks as late as the month of December. "The weather," he says, "has been very stormy and wet. I have been fretting rather impatiently. I had settled it in my mind to go out and get a fossil out of the rocks in order to vindicate the truth told by Hugh Miller, or rather, my own truth; for it was from me that Hugh got his fossils. It is true that I did not name them. Hugh Miller did. He called this fossil Asterolepis, a fish intermediate between Glyptolepis and Holoptychius.

"Since Hugh died, some cantankerous people have printed and made known that the scales figured by Hugh belonged to Glyptolepis, and the head bones belonged to Coccosteus-thus plainly intimating that Hugh had blundered, or that I had misled him; not knowing that in so doing they proclaimed their own ignorance,- - that the head, bones, scales, and fin-rays were found together-stuck together; and thus proving indisputably that they belonged to one fish. It is amazing what ignorance these London men exhibit. They get their views from books. They should study nature on the spot. They did not know that Hugh came to Thurso and examined and saw the fossils in 
their beds for himself. He saw one of those fish lying in a rocky ledge, but boggled at the toil necessary to raise it up. However, after he went to Edinburgh he wrote to me and asked me to raise it up, which I did; and he tells it in his Book. And yet ignorance says that Hugh's scales belonged to one fish, and the head bones to another !

"Four days ago I read in an Edinburgh paper a paragraph in which it was said that a Mr. Salter had been lecturing 'on the Order of Creation.' Towards the close of the paragraph Mr. Salter is represented as saying: "Notwithstanding what had been said by the lamented Hugh Miller, no true evidence of the existence of a fish, or any vertebrate animal, was to be found in rocks below the level of the Old Red Sandstone.' Now, this was not fair. All that Hugh said was on the authority of those who said they know. The bones I found in August vindicate the truth as stated by Hugh, and also the bones I found in October. I sent Sir Roderick, in May 1863, one of the same bones with the same kind of scale sticking on it. I sent him also two jaws, with many scales sticking on them."

A few clays later he says:- "I am not satisfied with that paragraph in the Edinburgh paper. It surely could not be Mr. Salter that inserted it. No one is better acquainted with geological matters than he is. Sir Roderick's right-hand man! What am I to think? Has Agassiz been imposed upon? Has Sir Roderick published a dream? "No true evidence of a fish or any vertebrate animal in rocks at a lower level than the old 
Red Sandstone!' Has some reporter erred? Or is there an error in the classification of the rocks? There's the point.

"Well, in vain did poor Hugh toil, and believe in many creations. How sad to think that he ruined his health for a shadow. And yet, three thousand years ago, all was said to be Vanity.

"I am anxious for a trial for a fossil fish to elucidate the point called in question; but I am not sheep enough to strike a single blow in wind and rain. And yet I am very anxious to get out at the rocks. I shall have to carry a weighty hammer and wedges, and to work hard besides."

So soon as the storm abated, Dick resumed his researches among the rocks. He went out with "hammers and chisels and a'." He began on the 4th of January 1864. It was hard frost. The rocky ledges were covered with thick ice, while long ice-pillars hung from every cliff. The sea was hushed and smooth, its ripples quietly laving the shore. Dick worked for three hours at the place where he had settled down, but he got nothing important-only three fish snouts, some halfheads of fish, jugular plates, gill covers, and fish scales in any quantity. All these he had known twenty years before.

Two days after he returned to the rocks. It was still hard frost. He found nothing new, only fish jaws, a half-head, and scales innumerable. He returned on the 12th and 14th of January, changing his ground from time to time; but the results were the same. Ho 
found the smiddy hammer very heavy, especially after working with it for some hours. But still he went on.

On the 20th of January he made his fifth trial. He was on the rocks before daylight. It was still hard frost. "I had chosen," he says, "new ground. I had great expectations. The tide was ebbing fast; and thundering, great, long, high rolling breakers, were dashing themselves on the rocks. And then what foam! I was obliged to wait until the sea had gone down. In the meantime I tried a new place. I raised three large lumps of rock. I split them, and found three rusty, ugly heads of Dipterus and scales. Nothing new. Then I went back to the real place.

"When I got there, I laid down my weights and recomnoitred. Alas! I saw no hope. The ledges were rotten. I worked until one o'clock at midday, and got only scales, two rotten heads, a bit of plant, and a bit of bone. On my way home I tried another and a very hard spot. I worked there until two o'clock, but found only scales, fin-rays, and gill-covers. I was now chagrined, tired, and hungry! So I returned home, weary and heavy laden." Next morning he was up at four, working at his trade.

In this way did Dick go on, trying to perfect the knowledge with which he was already partially acquainted, and also trying to acquire new knowledge by his persevering labour among the rocks, with hammer, and pick, and chisels, from day to day. He thus gradually accumulated a new store of fossils. The Asterolepis which he discovered, and which afterwards 
became the property of Mr. John Miller, F.G.S., was the finest that was ever found.**

Dick continued to read the papers on geology which appeared in the newspapers, and particularly in the Athencum. He could no longer afford to buy books. but he was not a man to believe passively in the views of other's, especially when they seemed to be contrary to his own observation of facts. He had a keen eye, and believed what he saw rather than what he read. He had many a hard fight with Peach and Mr. Miller of London, as to the order of creation.

"There has been no new arrangement," he says, "of the rocks in which the fossil fish have been found. Sir Roderick has figured the new fish as Silurian fossils, and the Silurian rocks are older than Old Red Sandstone; that is, they exist at a lower level. . . . It is true that, after the Durness discoveries, Hugh Miller for a time resisted the views of Sir Roderick as to a new classification of the rocks of the north-west of Scotland. Hugh could not bear the idea of his favourite Old Red giving way to the Cambrian - a deposit older even than the lower Silurian.

"For my own part, I care not much what name or" names geologists may give to the various rocks, or the time that was occupied in the accumulation of their respective strata. They were, doubtless, made in succession, after longer or shorter intervals of time. About eleven miles from Thurso there is a small precipice which clearly illustrates the subject. Standing in front

* We state this fact on the authority of Dr. Traquair. 
of it, I can see with my eyes and handle with my hands the successive strata of which it was originally composed. First, close at my feet, is a bed of rolled pebbles. That is the lowest exposed formation. Next, over that, is a bed of limestone. Then a bed of the ordinary Caithness fagstone; and over that a bed of boulder clay.

"Now, on looking attentively at the rolled pebbles, I find that they are similar to the rock on which they rest. Consequently the hills hereabout were as much stone as they are now before the pebbles were rolled. Next, we can see that these pebbles were rolling about in the lime, for they are crusted with lime just as almond sweetmeats are with sugar. Consequently the limestone was once soft and loose, and the pebbles had sunk amongst the lime, which now lies above them. Then a soft muddy clay was brought by water, and laid above the lime. The whole was hardened into stone. Was it beneath or above the water? That is a question; but stone it became.

"And then another change occurred. Some great power came into action, breaking up the rocks, and making clay out of them, in some places a hundred feet thick. We know that the clay had become stone, for we often find great lumps of stone amongst the boulder clay, which forms the surface soil of the county."

There was another thing that excited Dick's observation. When at the top of Morven, 2331 feet above the sea, he was much struck by the bed of rolled pebbles that graces its top and north front. "How long had they 
been there? How high the sea must once have stood if they were rolled up by it yonder! Otherwise, the hill must have got a great lift since it was at sealevel!"

All these things surprised and astonished Dick. He pondered them over in his mind. They spoke of a longpast era, when the sea had washed its billows over Caithness, and tossed about the rocks as if they were playthings. Morven had been submerged, or its summit had formed but a little island, along which the sea had laid down its bed of rolled pebbles.

"I have examined attentively," he said, "the cliffs of stony clays along the valley in which the river Thurso runs. They are so stern-looling, so bare, so densely compacted, that a man working with pick and shovél could make but small progress there. Indeed, they are almost as hard as solid rock. Hence it is that fossil shells still exist undecayed in those clays. They are perfectly impervious. No moisture, penetrates them. No decay goes on. And then every stone, and piece of stone, is all grooved and scratched, and furrowed and polished, in a way that running water alone could never have done. No tossing of waves, though ever so violent, could do it. No! If ice and icebergs did not do it, what did? None can tell. One thing is certain, that those clays are formed out of the rocks on which they lie. And many pieces of rocks are found among them that have travelled far,--rocks from as far as Skye!"

A lecture having been delivered at Haddington on geology by Mr. Finlayson, a copy of the newspaper con- 
taining the report was sent to Dick, on which he made the following observations:

"I fear that he does not hit the assertors of 'the development hypothesis' so very hard as he imagines. He must know that no geologist says or imagines that all the metamorphic rocks * were so formed at one and the same period of time. Though life may be obliterated over wide areas,--when the fiery tempest was over in one sea or part of a sea, the organisms would again find their way back to their old abodes. The metamorphic rocks are of many ages; and no one can say that, though the mud was changed and became siliceous, the overlying water was unfit to support life. It was the dead they are supposed to have obliterated; the living might have lived on, either in that locality or in some other.

"Hugh Miller tells us of a ship-captain who sailed for days through a shoal of dead floating haddocks; but haddocks are still caught and sold. Hugh Miller was a splendid writer, but he was so highly imaginative as to be rather unsafe to rely upon. Besides, one soon gets tired of all geological reasoning. There is nothing on which the mind of the reader can lay hold upon and rest. 'What is truth?' is an old question; but no man in his senses would seek for it in the books of geologists.

"Metamorphic action has arisen from many produc-

* Metamorphic, literally changed in form ; applied to rocks and rock formations which seem changed from their original condition by sonne external or internal agency.-PAGE's Handbook of Geolugy. 
ing causes. There have been changes from the action of heat, and changes without heat. To understand changes from the effects of heat, I suppose we must go to Iceland. To understand changes without heat, we have only to look around us.

"Last summer, I went one evening down to Murkle Bay. At one corner of the shore, at the west side of the bay, was a pile of sand. It had been accumulated, and lay on the land in a mass, blown up gradually in old times-no one knows how old. The sand was mixed with broken shells and small pebbles. Water had been finding its way through and amongst the sand. The shells had partly decayed. The lime [of the shells] had set, and bound the sand and pebbles, in some places, into a solid mass. In fact, it had became a stone-a rock. It required a smart blow of a hammer to break it. And in much the same way many a deposit of sand has thus become sandstone or freestone.

"Some years ago, I saw in the hands of Dr. Robert Chambers of Edinburgh a piece of siliceous quartzite. It had been taken from one of the metamorphic hills of Sutherland. It had evidently at one time been a mass of loose sand. In fact, it still resembled sandstone more than typical quartz. How it becane a mass of flinty stone I know not; but evidently not from the effects of heat.

"Some years ago there was a great talk of liquid silica, or liquid flint-flint, in fact, as thin as water. Many public buildings, it was said, had been built of a material so loose that under weather influences they were 
falling to pieces.* It was proposed to wash their fronts with this siliceous whitewash, and thus preserve them from further decay. Be that as it may, it is a fact that they can render the softest stone, even soft sand, as hard as flint. They do, in fact, manufacture stones. There is actually such a thing as liquid flint. Man makes it, and nature makes it. Now, you have only to suppose an irruption of liquid flint into soft strata, and very soon after the rock becomes metamorphic.

"I saw, with Mr. Peach of Wick, many of his Durness Silurian fossils-both from the limestone and quartzite. Hugh Miller knew of fossils in quartzite, found to the west of Thurso, such as Worm Holm. The hard metamorphic quartzite had once been loose sand, and under the action of the weather had become sand again.

"Many of Mr. Peach's limestone fossils were of flint. Indeed, all that I saw were flint casts. The shell had decayed; silica had gradually filled up the place of the shell; and you saw a form like it. Others were interior casts. But the limestone was not equally hard. Now these were from metamorphic rocks-rocks changed without fire, or any heat.

"No doubt there have been ontbursts of fiery or molten matt'r. The gneiss, or metamorphic rocks, to the south of Caithness have all veins of quartz and veins of red granite. These veins are thought to have been molten or hot, and injected into them. Of course, their action was to change the nature of the rocks into which

* The Houses of Parliament form an instance. 
the veins of molten matter were driven. But how, no one can tell. There is a slow metamorphic action, as well as a rapid one.

"Yet no one has any reason to think that such a thing as a universally destructive action ever occurred since life began. There might be death from irruptive forces in the sea at Norway or Iceland, yet none at Caithness or Leith. No one supposes that, though all fossils may have been obliterated in metamorphic strata, all life was destroyed at the same time in the overlying waters.

"Agassiz and Hugh Miller believed in many destructions of life, and in many new creations. But Hugh, before he died, knew that it was not so. In his Testimony of the Rocks, he traced existing forms backwards, through all the various deposits, and found no break until he came to the Chalk. 'If even then,' he said. By the expression 'If even then,' he referred to the microscopic animals of the chalk,--found to be still alive in the North Sea, and in the seas between America and Britain.

"In dredging for a platform for the submarine calje, microscopic shells, with flesh on them, were brought up from a depth of. a mile and a half. Ehrenberg, Humboldt, and Sir Roderick Murchison have said, that those shells brought up from the deep sca bottom are the same animal as those found entombed in chalk hills in millions.

"All metamorphic rocks are not of the same age; neither are all Silurian. Neither are Old Red Sandstone. 
Coal, or any other of the great deposits. Life, in my opinion, was never wholly obliterated since it first began. Some creatures have died out; but there are no proofs of any new creation."

It should be mentioned that the letters in which these observations occur, were written without the slightest idea of their ever coming under the notice of the public. They were mostly written for the information and amusement of his sister and his brother-in-law at Haddington. He required of his eldest sister, that his letters to her should be burnt as soon as read. They. were therefore destroyed. Fortunately, the letters to his youngest sister have been preserved. They have furnished us with some of the best descriptions of the scenery of Caithness. They have described much of Dick's scientific investigations, and also some of his domestic history. 


\section{CHAPTER XXII}

\section{DICK'S FRIENDS-FOSSILISING AND \\ MOSS-HUNTING.}

The Thurso people surrounded Dick with a considerable - degree of mystery. But the mystery was very much of their own making. They could not understand what "the man" was about. What could he mean by walking to Morven and Dorery, and bringing home only a few tufts of moss? What could be the reason of his digging with a pickaxe in old quarries, or pounding on the rocks by the sea-shore with a smiddy forehammer? Ordinary people were grinding away for a living, working hard at flagstones, or competing with each other for increased trade, whereas the half-daft baker was wandering about Caithness in his by-hours, gathering stones, ferns, and grasses. The whole thing was a mystery!

The boys no longer dogged him about, as if he had been the local idiot of the place. They rather kept out of his way; for people spoke of him as "uncanny," and "a wee thocht wrang." When he came down the middle of the street, on his way home from Dunnet Head or Banniskirk, they merely stood to one side, and. looked after him until he turned down Wilson's Lane. He was often bedrabbled about his feet and trousers. 
He had been out since one o'clock in the morning; but his long walk did not seem to have tired him, as he went on his way down the street in his long swinging walk.

He still dressed himself in his antediluvian garments. He still wore his swallow-tailed coat and his chimneypot hat. He could not afford much money for clothing. The only things he renewed from time to time were his trousers and his hob-nailed boots. Dress was very little to him. And yet he was a handsome man too, though he never thought of that. Dr. Shearer says his appearance reminded him of another of nature's enthusiastsMungo Park. He had the same compact round head and face, with "ambrosial clusters" curled; and the same genial, unaffected, and, to the last, remarkably juvenile expression.

If the Thurso people did not understand Dick's outer man, they still less understood his inner man. What was he? What occupied his thoughts? What was his belief? What was his religion? That was a great point in a Scotch town, where everybody knows everybody; and where men are judged very much according to the kirk that they attend. The opinions entertained about Dick on the latter subject were very unfavourable. Perhaps they had a great deal to do with the fallingoff in his business.

Many a petty inquisition was held about Dick in Thurso. What did he think about the first chapter of Genesis? What did he think about the Flood? Was he "soond" in his scriptural views? Like wiser men, he held his tongue. And, after all, why should they 
know anything of his imner thinkings? Why this perpetual inquisitioning into the things that thoughtful and conscientious men think and believe? "Wait till you are of my age, and wearing spectacles, and then $\mathrm{I}$ will talk to you," was his answer to an inquiring young friend. He might have added-" "Wait till you have acquired wisdom and experience; wait till you have laboured and searched as I have done, and waited patiently for more light; and then we will talk about the mysteries of the by-past world."

After all, what do we really know? It is but a mere speck in the infinite of knowledge. "No man can find out the work that God made from the beginning to the end." To use the words of Dr. Parker-" We live as in a twilight of knowledge, charged with revelations of order and beauty. We stedfastly look for a perfect light, which shall reveal perfect order and perfect beauty." *

But whatever the Thurso people might think about Dick's religious belief, there could be no doubt as to his character. He was a kindly, cordial, honest, high-principled man. Everybody acknowledged that. They might call him what names they pleased, but they could not fail to recognise the dignity and purity of his mind. He did his duty honestly by all men. Hence he enjoyed the friendship of some of the best men in the place. The young students almost worshipped him. He was constantly referred to as an anthority on scientific subjects; and no one could be more kind and

* Morphology of the Skull, p. 363. 
obliging when consulted, or more lavish in communicating the results of his careful observation and garnered thought of so many studious years.

Men who did not know him, thought him to be a morose man-strange, abstracted, and rather unsociable. But those who did know him, and were admitted to the sanctum of his bakehouse, found him the very reverse. There he was kindly, sociable, humorous, full of information, sometimes full of fancy, and always ready to communicate everything that he knew about the fossilbearing strata, the botany; and the natural history of Caithness.

"On one occasion," says Dr. Shearer, "a point was raised and settled rather dubiously on Mr. Dick's own ipse dixit. Without giving us any reason to suppose that he suspected any incredulity, he made his appearance at my father's honse in his baker's dress within a quarter of an hour afterwards, bringing with him an armful of books, from which he proceeded to quote in rapid succession, and then went away, leaving us amazed at his zeal and thoroughness. For it was one of his peculiarities - as it is with most enthusiasts-to believe that every person must be as deeply interested in his subject as he was himself."

It was not often, however, that Dick went into any person's house in Thurso. He declined invitations to breakfast with Sir George Sinclair, when he had distinguished men with him; and he declined all other invitations. When a public breakfast was given in honour of Hugh Miller, during one of his short visits to 
Thurso, Dick did not make his appearance. On that occasion it was suggested that a geological museum should be established in Thurso, and Dick, though absent, was suggested as the only person likely to obtain and to classify the specimens. But Dick was unwilling, - perhaps he had not the time necessary to undertake the work; and he declined the offer.

As he did not accept the entertainments of others, neither did he entertain others in his own house. The only exception was in the case of Mr. Peach. The following extract is from Mr. Peach's diary:- "Rose at 5 A.M. After disposing of many matters, I went to see Dick. What pleasure it is to meet him! This day, for the first time, I ate and drank with him. I asked him for a cup of tea. 'By all means,' he said. I was much arnazed with him and his housekeeper, Annie Mackay. There was no cloth on the table. The poor body was sadly put about. Dick, manlike, laughed at her dismay. This is the first time that I partook of food with him. He would often have asked me. He was dashed, because the first time I saw him he asked me to take wine; and because I refused (being a teetotaller), he thought I was above eating and drinking with him. He was much mistaken. He did not then know me."

Throughout his life, Dick was careful and abstemious. He lived frugally, spending very little upon himself. His only extravagance if such it can be called, was books. These he would have of the best editions, beautifully bound. His brother-in-law once offered to send 
him some prime whisky. "No" said he in reply, "but I thank you all the same. Spirits never enter this house, save when I cannot help it." His brother-inlaw then offered to send him some money. "God grant you more sense!" was his reply. "I want no sovereigns. It is of no use sending anything down here. Nothing is wanted. Delicacies would only injure health. Nothing like hard fare in going through the world. My old woman neither smokes, snuffs, nor drinks. She is just as tough as a rigwoodie, and can almost do without sleep. I must not pamper myself. 'Hardy' is the word with working people. Pampering does no good, but much evil. No, no! no pampering."

We have said that Dick was a solitary man. He delighted in the companionship of books, and enjoyed with them the solitude of his own thoughts. He never married. He had no family enjoyments, nor family cares. His only inmate was his Highland housekeeper, with whom he could have little mental communion. His only companion was his sister, though she was far away. With her he corresponded regularly to the close of his life. He told her his joys and sorrows, his discoveries among the rocks, his finding of ferns at Dunnet Head and among the Reay hills, and all the little events of his daily life.

Here, for instance, is a little bit of one of his letters to her, written on the 26th December 1863 :- -

"As the weather wore a fair face, I got up and away off to a spot, nearly five miles off, to gather ferns! What? Ferns at the end of December? Yes, ferns. I 
walked to a rocky precipice, and gathered about a dozen ferns. They must have been Peri? Yes, they were Peri! The longest was about fifteen inches. Three of them were beautiful and green-finely cut and lobed. In fact, I never saw prettier plants, and I was very proud of them-the more so, as I gathered them at the end of December. I knew that the Sea Spleenwort was green all the year round at the cliffs of Dunnet Head, as I had gathered it there in winter, but I did not know that the inland ferns were green at the end of December."

Here is another extract from a letter to his sister :"I observe that your husband is a rifleman. Tell him that I never fired off a gun in my life, and scarcely ever handled one. There are a great many riflemen here. They have two targets. Not long since I was nearly shot. I was on the shore, and some green hands had come out to practise. They stood aslant, and not hitting the target, their balls came pinging through the air repeatedly. At length, one ball hit a ledge near me, raising smoke and dust. I thought it time to be off, and got out of the way."

His sister was then lying on her deathbed, but he continued to write to her, endeavouring to cheer her up. He sent to her husband a long account of his digging up a fossil, at the end of 1863. He said, "Tell my sister that I have written all this, hoping that it may amuse her." His sister died about two months later. It need not be said how much he lamented her. She was the last of his family-his nearest, dearest friend. 
And he was soon to follow her. When informed of her death, he wrote to her husband:-

"My sister's death affects me much. I miss her now, and feel a want. I'll feel it more by and by. I know that all must die; but we have the hope that, though we die, yet we will live for ever. Yes! we hope to meet again." Three months later, he again wrote: "I have not lifted a hammer since Jane died. I think of her every day. . . They venerate the dead the most, who live as they desired."

Amongst those who sought the acquaintance of Dick in later years was a young gentleman connected with a bank in Thurso. He knew of Dick's solitariness, and of his dislike for new acquaintanceships. He wished much to meet him, but feared a repulse. At length he determined to make the attempt. After Dick's day's work was over, he looked in at the window, and then he entered the baker's shop. The scene he saw was characteristic. The only light in the house proceeded from a candle placed on a chair in the side room, where Robert Dick was deeply engaged in reading a book. He was in his working clothes; his shirt sleeves were tucked up; and his appearance indicated that he had been at his baking bench only a few moments before. What first filled the spectator's eye was the shadow of his massive head thrown upon the wall. The particular way in which he happened to be sitting caused the shadow to be very large, and, being well defined, and showing some of his features, it looked a striking chject. 
Dick, hearing the sound of footsteps, rose up with the candle, and taking it with him entered the shop by the back way. The visitor, scarcely knowing what tc say, asked for some of his biscuits. He said that, being a stranger, he had heard that Mr. Dick's biscuits were the best in town. The biscuits were given, and still the stranger hung about. He entered into conversation with Dick, and he asked whether he could not see some of his specimens. Dick said that he had at that time little that was worth seeing-in fact, he had already sold his fossils to Mr. Miller-but, if he would call again, he would with pleasure show him all that he had. Dick fixed the hour, stating that his visitor must be punctual to the minute. He explained that he had to stick to rigorous rules in that way, as he had to support himself by his business, and also because he was at times interrupted by persons calling for their own pleasure while he was engaged at his work.

The introduction being thus successfully accomplished, the visitor again called on Robert Dick to inspect his treasures. He was taken upstairs to the museum - a little bedroom or parlour - of which Dick carefully kept the key. Its appearance indicated that no duster or broom was plied there without his special permission. The chairs were laden with books, or specimens of plants or fossils. In a corner was laid his herbarium-consisting of numerous books in which his dried plants had been preserved. One part of the room might be likened to a quarry bed, because of the specimens of rocks lying there. 
Pointing to a board laid across a chair, and bearing a considerable number of stone slabs, cut and polished to an equal size, he said, "Now, that's Caithness." "How is that?" said the visitor. "These are the specimens of all the rocks of the county, from the most ancient to the most recent, and they are arranged accordingly." The localities were indicated from which the rocks had been taken, from Portskerra to 'Duncansby, from Morven to Dunnet Head. Dick then proceeded to show lins collection of ferns, and a beautiful sight they were.

Dick was most careful in preparing his herbarium. Not a single imperfect specimen was admitted. The way in which they were attached to the leaves of his books showed the artistic turn of his mind. The fine natural curves of the plants, grasses, and ferns, were carefully preserved. The very hairs about the stalks and leares were spread out at the correct angle; and the whole presented, as much as possible, the living character of the plants. All indicated an immense amount of labour, care, and observation. He wished to preserve them as he found them, in a state of nature. All their liabitats were carefully attached to the Caithness plants.

To resume the visits of his friend.-On one occasioni, when he passed through the shop and entered the bakehouse behind, he found the occupant merrily singing "The Soldier's Return." He immediately joined in the song. "Ah," sail Dick, suddenly looking up from his dough, "you've caught me." "I did not know you could 
sing, Mr. Dick." "Sing!" said he, "I believe I was born singing:"

The visitor proceeded to inspect the walls of the bakehouse. Like many others, he was struck by the firm, correct drawing of the figures on the walls. Though Dick had never studied drawing, he had a great love for the fine arts. He cultivated his taste, and was able not only to delineate plants with delicacy and neatness, but to draw in spirited outline the figures of men, and animals, and gods. He thus converted his bakehouse into a chamber of imagery.

The smooth plaster was his canvas, and on it he portrayed the creations of his fancy. At one time the walls would be resplendent with Cherubim and Seraphim and the angelic host. At another-for he often varied his drawings - they would exhibit the strange and weird-like forms of the animals that inlabited the ancient world. Sometimes there was a medley of figures-Egyptian kings and hieroglyphicswinged bulls and Assyrian gods from the sculptures of Nineveh-and in the midst of them, happy children "disporting nude."

Dick was intensely interested in Egypt and the old Ramesian period. He read every book he could find on the subject. In one of his letters, he says- "I am much delighted and fairly lost in Egypt_wandering in imagination amongst those

"“Temples, palaces, and tombs stupendous, Of which the very ruins are tremendous.'

"It was a rainy morning, and I had to be content with 
staying at home. I turned to and sketched in an outline of one of the gods of Egypt. It had a ram's head nn a human body. I worked away from eight o'clock in the morning until two o'clock in the afternoon, when I got it finished. I passed the rest of the evening in reading. In the midst of this evil weather, $I$ have been reading a number of books. I have read a volume on the Polar Seas and regions, another on Africa, another on Egypt, another on Nubia and Abyssinia, and I propose to go on with Palestine, Arabia, Persia, India, and New Zealand."

But amidst all his multifarious reading, ancient Egypt stood first in point of interest. "It seems," he said, "that these old people are not yet properly understood by our wisest men, and we fall into many mistakes, and put many constructions on their ancient works. They seemed to have recognised an Evil One or principle, which they named Typhon-a god, Osiris-a goddess Isis, and a whole multitude of 'gods many and lords many'-

\section{" 'Every garden was o'errun with gods.'}

One, or rather two of the figures which I have stuck up on the wall, exhibit a representation of the union of the Brute and the Human-that is, a cat's head on a human body. Cats were venerated in Egypt long ago. There may have been something satirical in this god. Very probably cat-witted people loved then as well as now. Then again, they had their ram-headed gods, and their hawk-headed gods; and, by your leave, we have all those sort cf living people yet." 
The visitor to Dick's bakehouse saw the numerous figures occupying the walls. Amongst them was a spirited and well-executed figure of the beautiful Greek boy drawing the thorn from his foot. This was over the fireplace. Beside it were two figures of Egyptian idols. On the side of one of the windows there was the figure of an ape, excellently drawn. What Dick thought of the development hypothesis may be understood from his figures of the Greek boy and the ape. They could be seen at the same glance from the door of the apartment, and presented a striking contrast, quite irreconcilable with the idea of even a remote identity. When questioned on the subject, Dick humorously indicated the presence of the two drawings. He pointed to them, but said nothing.

With respect to the Egyptian idols, he said of a friend who had called upon him and looked at them, "Perhaps he did not understand my Egyptian mythological divinities. Strange figures are these gods of Egyt, and yet they had a hidden meaning which no one nowadays rightly understands. Egypt was once the first of the nations, but the glory of its palaces has gone for ever. And all must perish but Truth. That alone is eternal!"

When the weather was fine, Dick again went to the fields or to the sea-shore. He was still anxious to find his whole big fish. Hence he continued to dig away at the rocks. Towards the end of 1864, Mr. George Henslow, son of the late Professor of Botany in Cambridge, wrote a letter to Dick, asking if he could send 
him some specimens of fossil fish in exchange for botanical specimens. To gratify his request, Dick searched along the shore; and, after an hour's labour with his heavy hammer, his wedges, and his chisels, the found a good fossil fish quite whole. Whether this was sent to Mr. Henslow we know not, as no further reference is made to the subject.

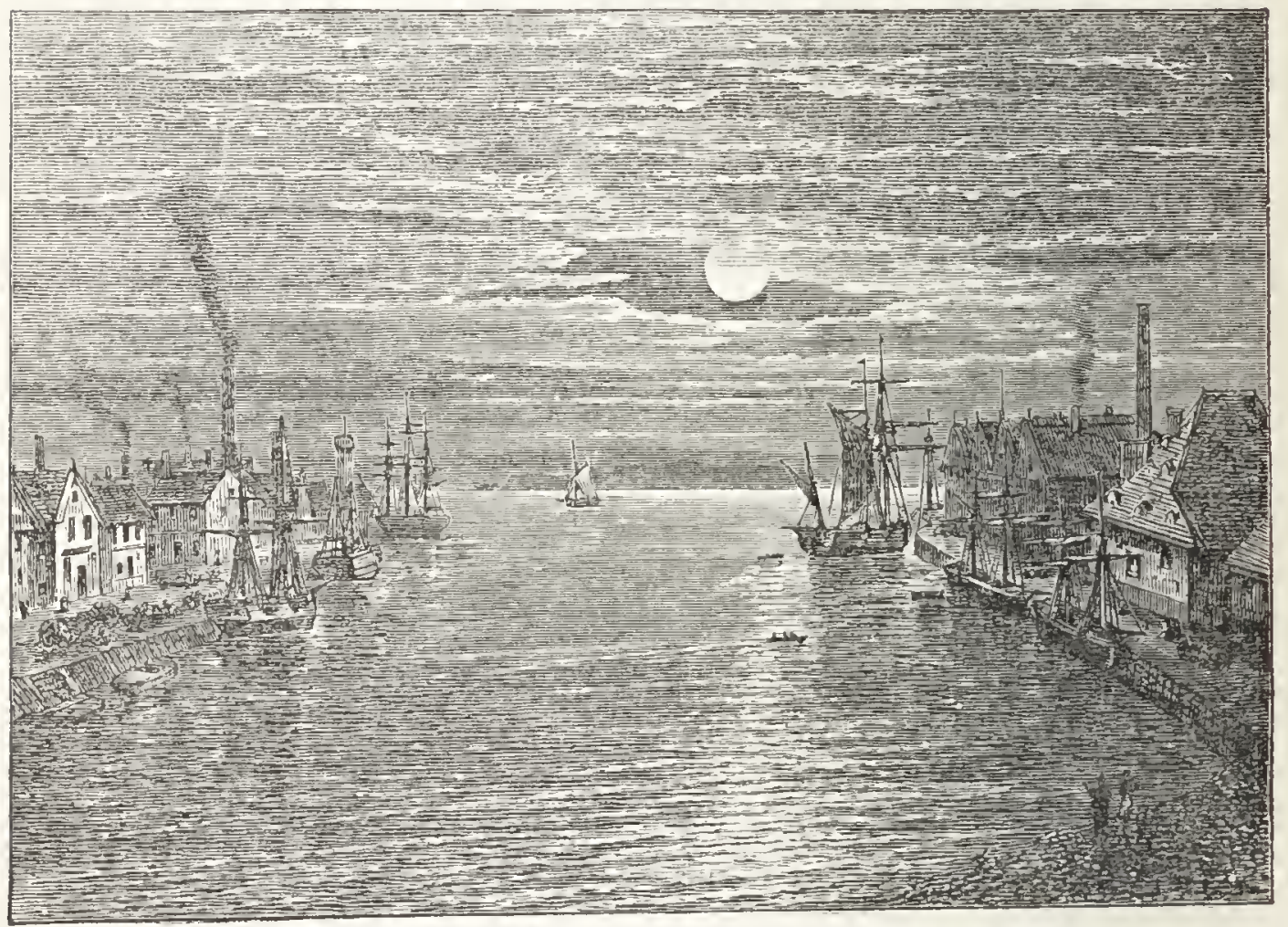

MOUTH OF THURSO RIVER.

About the same time Dick discovered another singular object. "A recent spate," he says, "laid bare part of the skeleton of a whale, which apparently liad been buried many hundreds of years. It was rery much decayed. It lay near the mouth of the rirer. Most probably some of the old Caithness cannibals feasted on the monster."

A Society for the study of Natural History was 
established in Thurso in 1865. Dick refers to it in the following terms :-

"Macculloch said that an uglier country than Caithness was hardly to be seen. God save the mark! is that true? A fine natural history society has been got up here, and in their wisdom they have thought proper to dub me an 'honorary member.' They go to-day on an excursion to Dunnet Mills. I wish they may not drown themselves."

On the following day he says:-- I am rery glad that I did not consent to go a-gowking to Dunnet Hills. The party went off in gigs, single and double; and what they saw, in crossing the sands, I know not. Certes, no one ever heard of objects in natural history being collected in gigs! The Society went to the inn and had dinner, and they did not rise until it was late. In coming kack across the sands, they drove their gigs into the sea! . . One lady was heard to lament that Mr. Dick was not witll them, were it only to keep them in order. Denend upon it, if Dick the baker had been there, the Society would have returned home before midnight! A fine 'honour' indeed!

" ' A countra lad is my degree,

An' few there be that ken me, $O$ !'

"Thurso had its museum party once before, bat it went to smoke chiefly through a want of funds, and also through a total want of zeal amongst the people for things of that sort. A love for those strudies cannot be forced, hardly even nursed into existence. But this attempt at a Museum bids fair to prosper." 
Dick seems to have had a dislike for men who went out geologising or botanising in gigs! After a hard morning's work, and a long ramble round the coast, with hammer and chisel, he returned, and entered the following remarks :- " On arriving at home, I found Dr. Hunt, from Londnn, had called. I met him on the road, in a gig of course. I did not know him, nor he me."

Dick continued to have many correspondents. They addressed him from far and near, asking him for fossil fish, and specimens of the Holy Grass. He provided the Rev. Mr. Brodie, geologist, with some fossils, and through his introduction several other geologists asked for the same. Mr. George Roberts, secretary to the London Geological Society, asked him to send some typical specimens of the oil-bearing shales for analysation. "Some influential city people," he said, "are quite willing to take the matter up, if the yield of bituminous oil promises to be a paying one." Mr. Roy, of Aberdeen, wrote to him stating that he would propose him as a member of the Aberdeen Natural History Society, provided he would supply him with a paper on the natural history of Caithness. Mr. Alfred Bell, of London, wrote him asking for a paper on the Hierochloë borealis, for insertion in his Natural History Circular.

Another of his correspondents was Mrr. Jamieson of Ellon, who sent him an abstract of his paper on the geology of Caithness. "I make mention," he said, "on your authority, of the gravel hillocks near Dirlot, as being the only ones that I had heard of. With regard to 
the valley gravel, it seemed to me to be less developed, even in proportion to the size of the rivers, than it is in other districts. There is some of it, however; and I agree with you in saying, as I do in my paper, that what does occur, appears to be the product of the rivers and streams cutting through the drift.

"I wish you would take a run, some time, along the northern seaboard of Sutherlandshire, and note the appearances presented by the valleys of the various mountain streams that join the sea. It would be desirable to ascertain whether any moraine-like heaps present themselves in such places, where you approach the mountains. On going along the east side of Sutherland, I noticed that the features of the comnty differed from those of Caithness. Great piles of gravel, arranged in mounds and abrupt hillocks, present themselves at the entrance of the valleys, and come down close upon the sea,-as is well seen at Brora. Now, it would be interesting to know if similar phenomena also occur along the north coast.

"The meeting of the Caithness plains with the high hills of Morven, the Pap, and the Scarabens, should also be investigated, in order to see whether any drift from north or north-west overlaps their base, or whether, on the other hand, the débris of these mountains 'protrudes in the form of moraine-like ridges. Foreign boulders should also be searched for on these hills. Paach tells me he saw hardly any. I walked along the Berridale glen from the base of the Scarabens to the sea, but did not manage to get round the northern base. I will 
send you a copy of my paper when it is printed, which will probably be some time this year.

"The valves of the Leda I got from you are pronounced by Mr. Gwymn Jeffreys to be Leda buccata of Steenstrup, which he seems to consider a variety of Leda parmula."

Here was a large stroke of work cut out for Robert Dick. But he was too poor, too rheumatic, too much overborne by troubles, to undertake it.

Nevertheless he continued his walls to within a reasonable distance of Thurso. He preferred walking along the shore. Sandside Bay was one of his favourite resorts. There he found old fishes in store, but none of them were of the best kind. In passing thither, he crossed the Forss Water by the bridge; and in the lower grounds he found a specimen of the Hicrochloë borcalis growing. He sought for it again, but he never found another. Besides, there were plenty along the Thurso binks, - quite enough to satisfy his numerous correspondents. Forss Water was one of his favourite spots. It rises in Shurery Loch, and comes tumbling down from rock to rock until it reaches the sea. The last fall is at Forss Mill, near where he found the specimen of the Holy Grass.

Robert Dick continued his correspondence witl. Charles Peach to the end of his life." The two had a

* In 1859 the Geologieal Society of London unanimonsly granted the Wollaston Medal to Mr. Charles Larwin, F.R.S. ; but a balance remained, which was awarled to $\mathrm{M}$ r. Charles Peach, for his discoveries in Geology. The president, Professor J. Phillips, on his handine the 


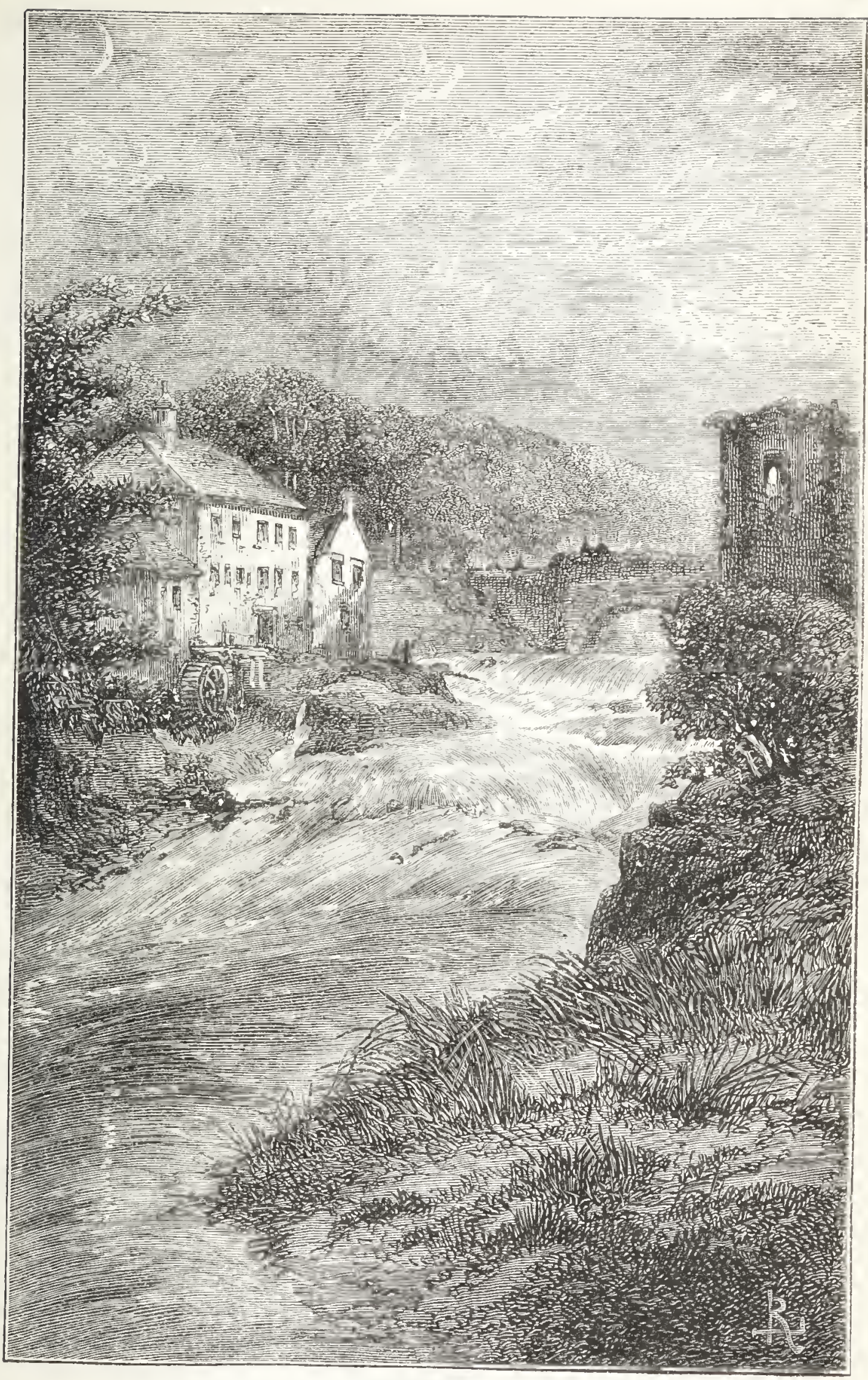

MILL AT FORSS. 

hearty, cordial, fellow-feeling. They communicated to each other everything that they found which was new. There was never the slightest feeling of jealousy between them. The last verses that Dick wrote to Peach were as follows:-

"Ye lang hae toddled roun' the land, An' hammer'd far and near; But feint a fossil ye hae fand Your drooping heart to cheer!

"A broken wee bit fish or twa, A doubtfu' bit o' stane, Ye carried south, wi' muckle blaw, To chiels, wha skeel had nane.

"A puff they whispered in your lug, And ye came laughin' hame, Weel drooked wi' the Hieland fog, And fand the whole a dream."

But Mr. Peach did find more fossils. In 1863, while working at Sarclet, on the Wick side of the county, he found part of a fossil crustaccan in the Red Sandstone, rising from beneath the flag-beds.* Sir

sum in a little purse to Sir Rodcrick MIurchison, requested him "to assure Mr. Peach of the pleasure which the Council and Socicty had in thus publicly acknowledging the persevcrance, acumen, and love of Natural History pursuits evinced by Mr. Peach, and especially the advantages accruing to geological science from his rescarches among the oldest palæozoic rocks, both at the southern and northern cxtremi. tics of the isłand, he having becn the first to find fossil remains in the old altered rocks of Sutherlandshire and Cornwall."

* Mrr. Peach says that the furst specimen of this fossil was found by Mr. R. Shcarcr, but that he afterwards found two other body segments a short distance from the same place. 
Roderick Murchison, on the authority of Professor Huxley, stated it to be part of a Pterygotus-or lobsterlike crustacean. Mr. Peach also discovered some specimens of the Tristichopterus alatus at John o' Groat's, which threw much light on the previously unknown points of its structure as well as on its affinities.

It would, indeed, be difficult to tell how much Mr. Peach found during his residence in Caithness. Among his other findings, he discovered a sea-snake. It was cast ashore in Sinclair's Bay, a few miles north of Wick. The length of the snake was fifteen feet six inches; its width about three and a half inches. Its head displayed a sort of mane or pendulous tuft. Its skin was of a beautiful silvery colour, with fine dark bands passing from the head to the tail. It was found to be a large specimen of the Gymnetrus,-better known by the name of riband-lath or deal-fish. A similar sea-snake has since been found by Mr. Trail at Dunnet Bay, near Thurso.

In 1863 Mr. Peach obtained from the rocks in the neighbourhood of John o' Groat's a fragment of a small Pterichthys. As this genus had not before been found in Caithness, he resolved,-although the locality was more than eighteen miles from his residence at Wick,to follow up the discovery; and he succeeded in finding, at different times, four or five pretty good specimens. At the meeting of the British Association at Dundee, in 1868, Mr. Peach read a short description of it to the Geological Section, and named it after his valued friend, Pterichthys Dicki. But we anticipate. 
We return to Charles Peach's history. We have already stated that he was stationed at Wick as Comptroller of Excise. Part of his business was to inspect the coast of Caithness-from Wick round Noss Head, Duncansby Head, Joln o' Groat's, and Dunnet Head, to Thurso, and from thence to Cape Wrath and Rhu-Stoir in Sutherlandshire. The east coast, from Dornoch Firth north to Wick, was also within his beat.

When he travelled by land, he went by mail-coach, mail-gigs, or carts, whichever was most convenient. Sometimes he went by boats along the coast. He was often very much exposed, especially in winter, to wind, frost, and snow-always bitter cold. When he heard of a wreck having taken place, he was off at once; his object being to save the ship and the crew, and to reward those who had been instrumental in saving life. He communicated with the Wreck Department of the Board of Trade, and recommended those who had acted gallantly. "I proposed," he said, "that medals and money should be publicly given, and I am proud and happy to say that the Board almost always attended to my recommendations. I always pushed hard for decorations; and many a man has been made prond of his bravery for life." Amid such harassing, distressing, and dangerous scenes, did Charles Peach carry on his researches into the Geology and Natural History of the northernmost counties of Scotland.

Peach was now getting an old man-not old in spirits, but old in years. He was constantly subject to attacks of cold and bronchitis. Indeed, he was often 
very ill. Dick wrote in one of his letters that he scarcely expected that he would recover. Nevertheless, he cheered him up as usual: "I am glad to hear you are in spirits at least, if not in health. So many people are going that I began to get apprehensive that you were seriously ill. Hope on for ever, dear Charlie." Peach had also many troubles connected with death and illness in his own family.

At length, in 1861, he was under the necessity of retiring from the service. He was now sixty-one. He had worked long and hard for his retiring allowance. Besides, a change was about to be made. The office of Comptroller, with a view to economy in the Customs, was to be done away with in all the ports of the United Kingdom. "MIr. Gladstone's long range," he said, "is about to ruin me." The older men were to be placed on the redundant list, and the younger ones were to be reduced to subordinate offices. Thongh Peach was at the top of the list for promotion to $\$ 200$ a year, he refused to be reduced, and he therefore retired upon a comparatively small amount, which lasts only during his lifetime, and leaves nothing for his widow. His hopes were thus dashed. The change had such a depressing effect upon him that he fell seriously ill, and for weeks was expected to die. But in course of time he recovered, and set to work again upon his favourite studies.

Mr. Peach accompanied Mr. Gwymn Jeffreys in his dredging expeditions along the shores of the Shetland Islands, and he there made a collection of British 
corals (Polyzoa), which would otherwise have been thrown away as waste. He never forgot what his keen eyes had detected, and he never threw away what he considered might be turned to some future account. The last time we saw Mr. Peach * he was engaged in preparing a paper on these waste objects, to be read before the Linnean Society. The paper was entitled "On Cellepora cervicomis of the British Seas."

Mr. Peach left Wick in May 1865, and took up his residence at a house in Leith. Walk, where he still lives.t He says, "I must work; I should soon die if idle. Work is life to me." He has consequently sent many papers to the Linnean and other scientific societies. One of these was on the British Polyzoa; another (read at the Royal Institution of Cornwall) on Zoophytes from the Cornish coast.

Among his various honours he was elected President of the Royal Physical Society of Edimburgh, and in his opening address he discoursed of the history of the Fossil Flora of the Old Red Sandstone of the North of Scotland. He was also presented by the Royal Society of Edinburgh with the Neill prize for the period 187174 , in acknowledgment of his extensive contributions to geological science. In fact, so long as Mr. Peach lives - he is now seventy-nine-lis name will be heard of. And yet he says he is not "an old man." He is still an "old boy." That is what his wife calls him. For he is cheerful, communicative, bright, and lively as ever.

* April 1878.

† 30 Haddington Place, Elinburgh. 
In May $1866 \mathrm{Mr}$. Peach sent Dick a photograph of himself, which had been taken at Edinburgh. Dick replied to his letter as follows:-

"I scarcely needed such a memento of you. I would always have remembered you. And indeed, should my memory have proved fallacious, still your plants would have unceasingly suggested an idea of you. I was amongst the Reay hills in March last, and was pleased to see the fern (Scolopendrium) growing beautifully, and both there and at Dunnet Hills the plant will endure and astomish some lonely wanderer, long after we are both out of time. Charles! you have thus reared an undying memento, and it was no vain thought which prompted you to bring to me so lovely an object.

" 'A thing of beauty is a joy for ever.'

It will be a joy to some who will remain igncrant of its history." 


\section{CHAPTER XXIII.}

DICK'S LAST YEAR-HIS DEATH.

LifE was becoming sad, and dreary, and full of sorrow, to Robert Dick. He was a victim to rheumatism. Sometimes he could scarcely move. "I am plagued," he says, "with rheumatism in my shoulder-blades; I can scarcely lift my arm." The rheumatism also affected his loins and feet. He could not walk; he could only "hirple." To one who had been so full of life and activity, this was a great trouble.

He was also much affected by his business. Competition was ruining half the bakers in Thurso. One man, who afterwards became a bankrupt, was underselling everybody, in bread, in tea, in groceries and everything. "Campbell," he says, "even sent the bell round forbidding people to drink milk, and recommending them to patronise his ale and porter. He sells most things under cost price, to the great injury of his fellow-tradesmen."

Dick's business again fell off more rapidly than before. "I am in a state of galloping ruin," he says to his brother-in-law. "I have nothing to do, I have made no loaf-bread for several weeks. My trade is suspended. To tell the truth, I have worked hard for my living for 
so very long, that I am nothing save when I am working regularly ... I was within a hairsbreadth of being off yesterday by steamer for Leith. Idleness will never do. If a man like me, after thiirty-five years' hard work, is compelled to work as a day-labourer, I will try if possible first to get out to Brisbane or New Zealand. . . . My sister Jane was a good friend to me. But the rorld runs round; and I was a fool for not being off in time from this starvation hole. Lord help us!"

But Dick was still the best biscuit-maker in Thurso. Surely he could sell his biscuits! No; competition again beset him. Campbell planted touters at the end of Wilson's Lane, and pressed the Highlanders, when on their way home from Wick to the Western Islands, to take their biscuits from the general competitor. "On Saturday," he says, "the Highlandmen came up from Wick to go by a steamer from Scrabster; and they continue to come all day, all yesterday (Sabbath), and kept coming until one or two this morning. I used to sell them on such occasions some thirty or forty stones of biscuit. This time I did not sell them more than twenty stones. So I'll take a run up to the hills, to complete my number of county ferns."

In fact, Dick could scarcely earn the wages of a daylabourer by working at his trade. The men who worked at flag-cutting by the river-side made from lialf-a-crown to three shillings a day. But Campbell had lessened Dick's earnings by ten and sixpence a week; and that, said he, "is a very great deal to take from a poor man like me. However, I must try and starve it out, hoping only for a reduction in the price of flour. 
His brother-in-law having wished him a "good new year," Dick replied: "So far as I am concerned, I have not the smallest hope of seeing a good new year any more in this world. That is all over long ago. You are young, and hope is strong in you; but you will yet learn that nothing satisfactory exists here below. The world is turned all over since I first knew it. Patience is best."

Yet Dick never lost his good temper, his charity, or his hope. To his brother-in-law, when in trouble, he said: "Never lose heart. Always look on the bright side of every cloud; and perhaps you may see the bow of hope beyond." He still went on collecting grasses, ferns, and flowering plants,-working, in the evenings, at the completion of his herbarium. In the meantime he went on collecting mosses.

"Some people," said he, "talk about Reform. I observe that the Franchise is to be reduced to $£ 6$ and £10. I wish the new voters may derive all the pleasure they expect. I never dabble in politics. It does not suit my nature. But other folk must be tickling themselves with straws, or grasping at shadows, not knowing that they are themselves to blame for the unhappiness that befalls them.

" ' Dear Nature is the kindliest.'

"By nature I mean plants, flowers, and flowerless mosses. I am still looking after and prying into these things. I think myself blest if I can find one moss in the week. By that you will understand that the pursuit of mosses is quite a new study to me. And yet twenty years ago I was looking at them, and picking 
them up, and putting them aside wrapt in paper, with the locality where found marked upon them.

"So I have got great numbers to overhaul. Last winter I turned to them in good earnest, and tired myself a hundred times over,-putting them to one side, and then turning to them again. I will get on slowly, slowly; but perseverance will do it."

He went out to the hills again. But the rain often stopped him,-ceaseless, pitiless, pelting rain. "The rain," he once said, "is killing me." But so soon as the weather cleared, he was out again. "I have made a ten hours' journey," he said in April 1866, "across the hills, but I got no new mosses. I sought for sea-shells about nine miles inland. I only got some little broken bits; but I found an entire half of the shell Astarte borealis. It was something to find even that so far away from the sea. Many, many changes have taken place since that shell was deposited. A wood of trees afterwards grew there. The wood perished, and peat moss, many feet thick, covers it up. And underneath that, the shell was found."

At the beginning of the following month he was again searching for fossils. "I have got," he says, "some large and very strong fossil bones from the rocks. I have seen nothing similar for twenty-three years. The outlines of the larger bone I have tried to trace out on this leaf" [gives a drawing of a fossil bone, about twelve inches across].

A fortnight later he says-" As I cannot be idle, I have turned over again to break stones. I have nearly 
killed myself several times by over-exertion; and after all, I have found nothing new. The days of great things are over for ever with me. And yet I am 'first fiddle,' in all that relates to the Old Fish. If you look at the latest edition of Hugh Miller's Footprints of the Creator, you will see figured there many things of mine, which I never hope to see again. The sea must wash down the rocks for five hundred years first, and by that time we shall all be resolved into dust and ashes.

"Alas for the old days! They are gone for ever. Well, I will return to my plants. But even there, I fag and limp listlessly. Nothing new! With mosses I still get up the steam. But they are so comparatively trifling, that I sometimes weary of them.

"To tell you the truth, I am perfectly tired of this insipid, tasteless, dull, motionless kind of existence. I would willingly change, if I only knew where to change for the better. All is dull and tasteless.

"On going over the old fossil ground again, there is much need for enthusiastic steam. The dreams of old will not return. All is in vain. Yet I will try again,yes, with the aid of spectacles. For my eyesight is not so sharp as it once was."

He again went out to the hills, to gather more ferns. But he had exhausted the subject. "I have overhauled so much of the county before now, that very likely I may find only a repetition of former things. A county holds comparatively few of the British Flora; and a Northern county fewer than a Southern one. For, however vain dreamers may blow and puff, heat is 
required for all vegetation. The wise man said, thousands of years ago, that "nothing is hid from the heat of the sun,' and the wise man was right."

One morning, after he had got his work done, he went out at four o'clock, to revisit for the last time a selection of boulder clay by the river-side, about nine miles from Thurso. His object was to ascertain whether the late rains had exposed some shell or other fossil worthy of being collected. He had before found shells in the same place. It was moonlight, bright moonlight; and he had a delightful walk by the river-side. When the moon became clouded, the stars came out, and they were extremely lovely.

During his walk, he recognised a boulder stone which had been brought by the ice from Helmsdale, Sutherlandshire, on the other side of the Morven hills.

"And dost thou still, thou mass of breatling stone, Thy giant limbs to night and chaos hurled, Still sit as on a fragment of a world, Surviving all?"

These were the lines of Rogers that floated through his imagination. "Poor creatures that we are," he said, "speculating about things that we know so little of. And look at these stars, so far off in the infinite. What do we know about them? Are they also suns, each the centre of a planetary system? Do the beings who live there, enjoy and suffer and die as we do? Alas! how little we know of the world we live in."

Towards the end of lis life, Dick read Colenso's Pentateuch, and the book of Joshua. It was the work 
of a bishop of the Church of England, who must surely know something about the Bible and its origin. Dick was very much struck by its cleverness and its mockery. He likened the book to Samson pulling down the temple of the Philistines. "It is very clever," he said; "but what do we gain by it? Nothing whatever! Rather we have lost. A little more unhappiness is all the immediate result. Some of our dreams have fled, and left us groping in uncertainty. Is there nothing sure? And yet there must be such a thing as truth. But who is to decide, and tell us what truth is? The books of the Bible may be full of errors, but what would become of mankind without it?"

Dick's letters show that his mind was much depressed about this time. He seems to have had fewer friends than ever. He sometimes speaks severely about the Thurso merchants; "but," he adds, "it all arises from a want of business. Indeed there is only one merchant in Thurso who has anything like full employment." Dick may possibly have become embittered through his own want of success in life.

"I have got," he said to his brother-in-law, "Mr. Carlyle's fine oration at Edinburgh. Many thanks. I have seen the same gentleman, and have talked to him. Sir George Sinclair brought him to me, so that I might see him, and he could look on me. Mr. Carlyle said in his speech that labour was a cure for every human malady. He was right so far; and if Thurso folks had more and better-paying employment, there would be less spite and malice among them. And yet, mark you, 
they are about the most religious and professing people on the face of the earth.

"You have been speaking of our railway projects. Just as usual-a barking and bickering affair. Thurso and Wick cannot agree. Very lately they were burning here an effigy of a man of straw, which they named the editor of the Northern Ensign. And the Wick folk burnt our John George Sinclair, son of Sir George Sinclair,-all because they differed in their notions of what was what."

His brother-in-law having sent him his photograph, Dick said: "Of course, I ought in return to send you 'mysel,' but there is no one here but a watchmaker who does anything that way; and some people have got themselves made so very unlike life, that I prefer not trusting to be made a mock of.

"Yet you may some time or another see me; and in the meantime, to assist your imagination, you can just fancy a round-faced, grey-whiskered, laughing fellow. Indeed, so much is that my character, that a young man, now in New Zealand, used to say of me that I was always laughing. In fact, that young man often came to me sad and sad enough, and I always sent him away laughing too. He still remembers me, and sends me the New Zealand papers."

Dick was still working at his grasses in order to complete his herbarium :- "I am anxious," he said, "to complete my British grasses-no very easy matter, as botanists generally despise grasses. Why they should do so is a mystery to me, for grasses are very interesting plants. 
"A gentleman in Aberdeen wrote to me about the Holy Grass. I put in a word for two grasses I wanted. He sent me those two, and in return for them I sent him fifty specimens of Caithness grass.

"Another gentleman in London has asked me for shells from our shores, and I have supplied him as far as I could-on condition of receiving grass for grass."

Again he says (20th August 1866) :-

"I have not got many rambles this summer, and I blame that as the cause of the weakness in my stomach. I used to be such a great walker, and the change is telling on me."

Nine days after this letter was written, Dick took his last walk. He had for some time been complaining of his health. At first he thought that it was indigestion that troubled him. "If I eat I choke," he says. Then he complained of his want of breath. Indeed, few constitutions could have stood the amount of toil, labour, and privation, which he had endured during his long course of inquiry into the fossils, plants, grasses, and mosses, over the length and breadth of Caithness. He had often walked from fifty to eighty miles between one baking and another, with little more in his scrip than a few pieces of biscuit. Youth can endure many privations, but when a man becomes comparatively old-and Dick was now fifty-five-he cannot evade with impunity the requirements of nature.

Dick took his last journey on the 29th of August 1866. He thus describes it:-

"A week ago I went to a quarry at noon to search for a fossil, if I could possibly find such a thing. 
"I felt a burning pain under my breast-bone, in my stomach ... I was not well at all. Scorning to yield, I pushed on, but only grew worse.

"I reached the quarry, but only to become conscious that I might as soon think of dancing on my crown as to look among the stones for the dead or the living.

"After sitting down a little, I felt that my wisest way was just to go home again-if I could. I was hardly able to get out of the quarry; I had become so giddy.

"I got out though, and staggered up a hill, and sat down. I then became terribly sick. 'Ha! ha!' said I, 'surely I must be better now.' No; I tried to rise up, but was so giddy that I could scarcely stand; I could not balance myself. But I got up and went a little, and sat down. Up again, went on, sat down. I got up and sat down nearly a dozen times in succession; all the while the burning pain in my breast was cruel.

"After I had battled on for trro miles I got sick again. 'This won't do,' said I; 'I don't fancy dying amongst the heather.' So I tried to run. I got on a bit, in a zigzag way, and then threw myself down. I got up and off again, and at length found myself on the public road. I moved on in a drunken sort of fashion -half-blind too-and threw myself down on a dyke beside the river.

"After resting a little, I got up and made a dash for the river Thurso, through which I waded, just as I was, luran deep. There's a blenching-green by our river, and many old wives were there. I grew sick again in the 
midst of them-dreadfully! No doubt they wondered, as Dick the baker never drank whisky.

"At length I got home and went to bed. I have slept none for nearly a week, but the terrible burning pain has left me. My head is still so giddy that I can hardly go up stairs."

This was the beginning of the end. Ill though he was, he continued to go on with his daily work. His legs began to swell, until, as he said, they were like to burst. And then his breath was so bad that he added, "I am like a broken-winded horse." This was extraordinary to him, as he used to pride himself on his "long wind."

He slept very little, but when he slept at all, he woke "gasping for breath." Then he got up and sat on a chair, sometimes all night-occassonally with his head on a table. He tried hunger and cold water. Indeed, he had no appetite. And yet he did his day's work, though with much difficulty.

One night he prepared his work for the following morning. He wished to have four hours' sleep, but he soon got up, gasping. He took hold of the bed-post " to blaw." He tried to sleep again. It was of no use. "Nothing but suffering." Then he got up and went down to the kitchen fire, laid his head on a table, and tried to sleep, but he could not. Ile accordingly got up at one in the morning and began his day's work. "Though want of breath and want of strength were hard on me," he says, "I battled away, and ultimately filled my oven with capital bread, and my brcathing got a 
little easier. And there it stands. I am not at all well, but Hope-

" Hope springs eternal in the human breast.'

"I have sent you," he said to his brother-in-law, "a Thurso paper full of holes-holes out of which I have cut words such as 'Thurso,' 'Caithness,' 'Dunnet,' etc., for my plants." For he was still working away at intervals on his herbarium.

$\mathrm{He}$ got no better. Sometimes he was relieved, and then he grew worse again. He thought it was an internal fever burning him up, and causing an enormous drinking of cold water. "I do not say I will go this time," he says, "but my symptoms are much the same as Jane's, my father's, and Ann's." In fact, it was disease of the heart under which he laboured, and perhaps of the liver. Hence his dropsical symptoms.

He still continued his correspondence, though his writing became weak and shaky-like that of a sick man. He also continued his daily work. On the 1st of October he writes:-

"See the wretch, who long has tossed

On the thorny bed of pain,

Recruit his health and vigour lost,

And live and walk again.

The blooming earth, the sun, the skies,

To him are opening paradise." "

"A solemn truth; and none but those who have been in some measure afflicted, and tossed, and racked, and wearied out of all patience, can know anything of the 
blessedness of the relief one feels when the disease from which he has been suffering is passing away.

"The fever has got a check, and from this time forth a new life will dawn upon me. I have got relief in my gasping for breath, and I can now lie in my bed at night until I choose to rise. I still moan and complain a great deal in my sleep, but I don't get outrageous and wild, frightening the old woman, puir body! Indeed, I am a good deal better, and though quite impatient under this dire affliction, and at times almost hopeless, I still, upon the whole, cherish the hope of ultimate recovery."

But he hoped against hope. Death had laid hold of him. Dr. Shearer says the disease of which he died was aneurism, leading to cardiac complication and dropsya disease to which his laborious calling and extraordinary exertions in travelling and climbing rocks and mountains would particularly predispose him.

His housekeeper pressed him to send for the doctor. "No," said he, "no doctor. If I am to die, then I must die." In fact, he did not care very much for doctors. He thought their "cures" were very much the result of happy guessing. "If it has taken me," he said, "a lifetime to ascertain the nature of plants and animals, is it likely tliat a four years' curriculum can fit any man to comprehend the mysterious processes of the living liuman body?" Besides, there was the expense of calling in a doctor!

At length, after he had been seriously ill for about, two months, his friend, Mr. John Miller of London, came down to Thuurso and called upon Dick. He was amazed 
to find the great change that disease had made in his appearance; and he insisted upon Dr. Mill being sent for. As for the expense, he would cheerfully pay the doctor's bill. Dick expostulated, but it was of no use. The doctor wis sent for. He put Dick under a course of treatment for the purpose of reducing the swelling in his limbs. Writing to his brother-in-law on the subject, he said: "A good deal depends on the way in which we take these things. I keep up my heart, and struggle bravely against all my troubles."

When the doctor urged him to give up work and engage a journeyman, he said: "All buff! my only chance is to continue at my daily work." He therefore continued at his work, although his legs were fit to burst. Indeed, they did burst. But he still kept at his work. About a fortnight before his death, his brotherin-law, knowing the hard straits to whish he was reduced, offered to send him some money. Dick answered: "I am no better. The swelling is steadily moving upward. You offer to send me a present? No, no! But I will take a present from you of a pair of spectacles. My present ones are too weak." His friend, nevertheless, sent him four sovereigns and a pair of spectacles.

He was scarcely able to write when he received his brother's kindly gift. But he did write, with a very straggling restless hand. He was now in bed, and never got up again. He said: "Your kind favour of $£ 4$ came duly, and not the spectacles as I had expected, for which I return you many thousand thanks. I am no better. My legs are running water, and very disagreeable." In 
a postscript, written the day after, he said: "The spectacles are here this morning, but I am no better. Many thousand thanks. Long life to you. Adieu!"

He had still one more letter to write. It was to his dear friend Charles Peach. Mr. Peach did not know of Dick's illness, but a few days before his death he wrote him a long letter. "Dear fellow," says Mr. Peach, "what could he do more to show the respect that he bore for me, than by writing in his agony the subjoined letter? Oh! how it cut me to know that we were so soon to part. Although the most mournful letter that I ever received, it is comforting to me to find that I was not forgotten by him, even in his entrance to the dark valley."

Dick's last letter was as follows:- "Thurso, 15th December 1866. - My dear Sir-Instead of sending you a long letter in return for your kind one, I fear that I cannot write to you at all. I have been for four months unable to do anything by swollen limbs-water on the chest in fact; and lest I should die, I only notice you. I am very poorly, so you will excuse me. I am not able. No rest night or day.-Believe me ever yours very truly,

RoBert Dich."

Mr. John Miller continued his kindness to Dick to the end of his days. He sent his housekeeper, Mrs. Harold, to nurse him. She attended carefully to his wants. When she first dressed his legs, he felt much relief. He ejaculated, "That's a blessing. It's just like an angel sent from heaven."

He knew that he was dying. Mrs. Harold said to him, "You may yet get better." "No!" said he; "the 
days of miracles are past." His mind occasionally wandered. Once, in his agony, he exclained, "Oh mother! mother!" He thought he was grasping her hand.

One night he thought that a batch was in the oven. He was convinced that it was there, and that the bread must be taken out. He insisted on being carried into the bakehouse to see it. He was taken to the front of the oven. The door was opened, and it was all black inside. The bread was not there. The oven was never more to be lighted. He looked round the walls, and recognised his old drawings. He was now ready to faint, and was taken back to his bed.

Amongst those who visited Dick towards the end of his illness were his excellent friends Mr. John Miller, Sir George Sinclair, Mr. Wallace the coast missionary, Mr. Brims, procurator-fiscal, and Mr. Miller the respected minister of the parish. Mr. Miller prayed with him, and read to him the fourteenth chapter of St. John. Christ's words were a great consolation to Dick on his bed of death. Mr. Miller says of him that "he was the most hrmble believer that he ever met."

Dick was ready to depart. He was wearied of life. It was better that he should die. He had been oppressed with poverty, and now he was oppressed with agony. Why should he remain a little longer? He had done his appointed work, and was now more than resigned to leave it. He longed to be at rest.

In the morning of the 24th of December, Robert Dick's spirit returned to Him who gave it. Towards the end, his sufferings left lim, and he died quietly and 
peacefully. He was left in the hands of the Wise and Loving.

Towards the end of his life, much sympathy was expressed for Dick and his condition. The few people who continued to deal with him, had long known of his illness. Four months elapsed between the time when he was struck by death in the quarry, and the day of his death. His customers saw him growing feebler and feebler, panting for breath, and yet continuing at his daily work. It was only during the last fortnight of his life, that he finally dropped from their sight. Then they heard of his intense sufferings, and of the unwearied resignation and indomitable fortitude with which he bore them. The sympathy which his illness excited was almost intense. The Thurso people felt that a great though comparatively unknown man was about to pass away. At his death there was an almost universal sob throughout the town.

He was also mourned by others who had known him intimately, and valued him for his kindliness, his nobleness, and his love of science. Amongst these was Charles Peach, of Edinburgh. "After many years of close friendship for him," he said to Sir Roderick Murchison, "I had come to love him. He was such a cheerful and intelligent companion. At the same time, he was as fond of my pursuits as I was myself; and thus a bond of brotherhood existed between us."

Sir Roderick was then issuing the fourth edition of his Siluria to the public. He there says-"Alas! whilst 
these pages are printing, I have to record the death of this remarkable man. Robert Dick was unquestionably gifted with genius, and possessed of great original strength of mind. That he had a strong poetic verve was proved by his having purchased fine editions of the works of Burns, Scott, Byron, and other poets, out of his scanty earnings; for he was a baker, ever much engaged in hard manual labour. On one of my visits to Thurso, when we were lamenting over the want of a.map of Caithness, he prepared for my instruction a model in flour, which he manipulated into hills, valleys, and watercourses, and thus brought into relief all the surrounding country. He was as well acquainted with every living British plant as he was with all the Caithness fossils. Admiring, as I did, such energy and ability in a modest working man, I rejoice to know that it has been resolved to erect a monument to his memory at Thurso." *

On the day of his death, Mr. James Mill, chief magistrate of Thurso, issued the following announcement:- "Mr. Robert Dick died at his house here this moruing at half-past six o'clock. Through his vigorous and energetic study of the Geology and Botany of Caithness, he has been instrumental in developing the natural history of our county, and in attracting the attention of the Scientific World to its resources in no ordinary degree; and when we look back on his labours in the field for the last thirty years, we feel that Robert Dick merits from the people of Caithness a Public

*Siluria. Funth litition, 1. 269. 
Funeral, as the most suitable way in which they can express their gratitude for what he has done, and their sorrow for his removal from amongst us. We accordingly invite all who wish to testify their respect for our departed friend to assemble at his house in Thurso on Thursday, the 27th current, at one o'clock p.m., to accompany his remains to the New Burial Ground of Thurso."

Of all the things that Robert Dick could have desired, the very last would have been a public funeral. He was so modest in all that he did, so unwilling to be talked or written about, so retired and self-sacrificing in everything - that carrying his remains to the grave amidst the sound of drums and trumpets would have been altogether revolting to him. But all this was done by the Thurso people in respect for his memory, and that it might be known that a great though modest man had gone out from amongst them.

The funeral was largely attended. Men came from Wick and Castlehill, and from the country far and near, to be present. All the shops and places of business in the town were closed during the funeral. The procession was led by the bands of the Thurso rifles and artillery playing the Dead March in Saul. After them were the Volunteer Rifle Corps and the Volunteer Artillery Corps. Then came the coffin carried shoulder-high; pall-bearers, Sir George Sinclair, Bart., James Mill, Esq., Chief Magistrate, and William Bremner, Esq. The Clergy; the office-bearers of the Thurso Scientific Society; the various trades,--including the bakers, masons, tailors, 
seamen and fishermen, shoemakers, merchants, pavementcutters, and the general public; followed the remains to the cemetery. It was one of the largest, most impressive, and remarkable funerals, that had ever been seen in Thurso.

The new cemetery, in which Robert Dick's remains were laid, is about a mile from the town. It overlooks the banks of boulder clay on which the geologist had spent so much of his time. The place where he had discovered the Hierochloë borealis is near at hand, on the sward by the river-side. Far off is seen the entrance to the river Thurso, the ships in the offing, Dunnet Head, and in the distance the island of Hoy in the Orkneys. He was laid in the midst of the scenes which he knew so well, and where he had spent so many nights of patient and toilful plodding, while so many others were enjoying their peaceful repose.

After the funeral came the winding up of Dick's affairs. We have said that he was a poor man. At his death he owed a considerable sum-over $£ 72$ - to his flour-merchant in Leith. His mind was much troubled before he died about how this amount was to be paid. There were, however, the flour in his bakehouse, the books in his library, and his furniture, such as it was, as security. He was never able to repay his sister the sum of money which he had borrowed from her on the shipwreck of his flour; but he had the sum in his clothes-chest, in sovereigns of many coinages, which his brother-in-law thinks he intended to repay. But he never found himself in circumstances sufficient to enable him to return the amount. 
If he had been able to leave anything to anybody, he would have done so to his housekeeper, Annie Mackay, a worthy, independent-minded woman, who had served him faithfully for thirty years. But he died without making any will, as he had nothing to leave.

The flour, the books, and the furniture were sold by "public roup," and they realised sufficient to pay his ordinary debts. The furniture of one room was given to Annie Mackay, who still lives, to laud, amidst tears, her kind and good "maister." How she contrives to live is a mystery.

Dick's library was extensive. It consisted of twenty-seven volumes on Geology, eighteen volumes on Botany, eight volumes on Conchology, nineteen volumes on Entomology, thirty-three volumes of the Naturalist's Library, twenty-seven volumes of the Penny Cyclopedia, thirty-eight volumes of the Edinburgh Cabinet Library, and two hundred and twenty-nine volumes on miscellaneous subjects, many of which were of a scientific character,-in all, three hundred and eighty-nine volumes. The whole of these were sold for $£ 32: 12 \mathrm{~s}$, or at less than two shillings a volume. But second-hand books never sell well, even when they are the property of a genius; and especially when they are of a scientific character.

While Dick lay ill, his kind friend Mr. Miller asked his consent to apply to the Queen for a pension for his geological discoveries. Mr. Miller's intention was to ask Sir Roderick Murchison to use his influence with scientific men in London, to sign and support the necessary memorial to her Majesty with that object. Dick, when 
writing to his step-sister on the 7th November, said :"I am not so sanguine on that point as Mr. Miller is; but I gave my consent to allow him to get a pension little or muckle; it will be a great matter to me."

But it was too late. Before the Queen's mercy could be appealed to, a pension was no longer needed. Dick's spirit had left its frail tenement of clay. 


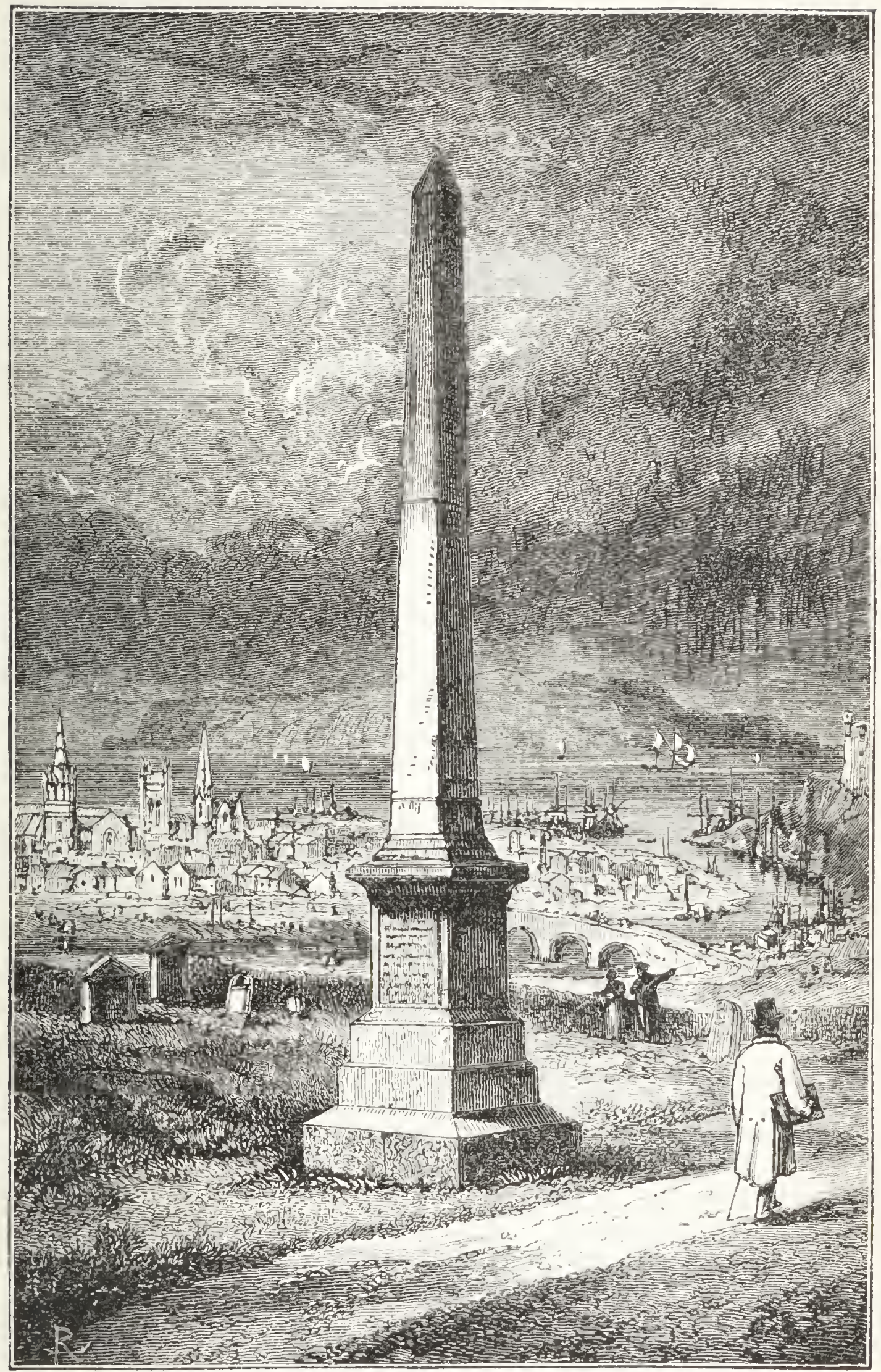

MONCMENT TO ROBERT DICK IN THCISO CEMETERY. 



\section{CHAPTER XXIT.}

CHARACTERISTICS.

Robert Dick died early. Yet he had lived more than most men. He had worked hard to obtain knowledge. He had worked hard for the love of science. He diu not work for his homour and glory. He gave freely to others, without any thought of reward. In this respect he was entirely self-sacrificing.

We have said that his youth was unhappy. His mother died when he was a boy, yet he remembered her to the day of his death. After that he suffered injustice which threw a shadow over his future life. There was no gentleness about his bringing-up. For relief he went to the fields and the mountains, and fell in love with the beauties of nature. The taste never left him.

The tears of childhood soon dry up, and then begin the sighs of manhood. But Dick, though brought up to a life of hard work, was never daunted. He tried to make the best of his life, such as it was. When he settled at Thurso, he again threw himself into nature. Though baffled in his affections, he forgot his sorrow in his strivings after knowledge. His natural disposition, though thwarted, was never soured. 
The sea was his delight. He wandered along the shores, and found things rich and beautiful and full of wonder. Though he wandered about solitary, he had no time for melancholy dreams. Every flower melted him, every star touched him, even every beetle engraved itself upon his mind. He was a reverent man. Unbelief is blindness, but his mind was all eyes, and his imagination was full of light, and life, and being.

The earth became to him, in a measure, transparent. It drew him out of the narrow sphere of self-interest. Everywhere he saw significancies, laws, chains of cause and effect, endlessly interlinked. He could not theorise about what he saw. He wanted the true foundationfacts. "Let us have facts," he said, "real, certain, unmistakable facts; there can be no science without them."

Geology was at first a great mystery to hinı. It seemed to him, as it really was, a revelation of the physical conditions of the by-past world. The rocks near Thurso spoke to him of a time when the Coccosteus, large and small, covered with berry bones - the Osteolepis, with enamelled bony scales-the wrinkled ganoid Holoptychius, the gigantic Asterolepis, covered with star scales - had ranged at will over the length and breadth of Caithness.

All these had, at some remote period, been destroyed by violent death,- - either by a sudden retirement of the sea, or by a sudden uplifting of the land. Platforms of death rose one above another, story above story, the floor of each bearing its record of disaster and sudden 
confusion. Wide areas of seas were depopulated, but the dead fish remained. They were left in the mud. The mud and fish became Caithness flag-now the support of a large population. "Thus Thurso itself," said Dick, "is built of dead fish."

But that time passed away, and the sea went rolling over Caithness. Ponderous glaciers went grating along the mountain sides of the Scaraben range, grinding its rocks down into clay, and strewing the deep-sea bottom with gigantic boulders. Amongst the boulders and boulder clay, which forms a large part of the comnty of Caithness, Dick found the numerous marine shells which have been described in the previous pages.

All this was very mysterious to Dick. The preoccupancy of the seas by the fishy tribes, and the present joint tenancy of the land by man and the lower creation, were two striking facts which strongly impressed his imagination. Might not this be the first cycle of the geological manifestation of the globe; or rather the first of a series of cycles, at whose close the existing races of living beings, and the gorgeous fabrics of national vanity, shall yield their haughty relics to the sport and desolation of the elements, - when new heavens and a new earth shall replace the ruins of a world?

Although Dick devoted a great part of his spare time to botany, it was to geology that he devoted so large a share of his attention. It was Mantell's Wonders of Geology that first attracted him to the subject; then Buckland's Bridgewater Treatise, and after that Hugh Miller's Old Red Sandstone. He had already found 
the fossil bones of the Holoptychius, the gigantic ganoid fish of the Old Red, before he became acquainted with Hugh Miller. He sent the specimen to Edinburgh, and received Hugh's warm acknowledgments. The correspondence between them at length ripened into a warm intimacy, and Dick continued to send to Miller, as long as he lived, the best of his findings among the fossil fish of Caithness. "Indeed," says Mr. Peach, "Dick was Hugh's greatest benefactor, and gave him more solid assistance than any other person."

Dick was one of the most unselfish of men. He made every one free to his stores of knowledge. He gave freely, without any hope of reward. He had no jealousy, no mean rivalry. Though he hammered and chiseled for fossils, sometimes at the risk of his life, he sent everything that was valuable to Hugh Millereverything that was calculated to establish his views, and to turn his gathered treasures to account in the establishment of scientific truth. "But for him," says one of his friends, "and his sedulous and faithful attachment to Hugh Miller, in the capacity of 'lion's provider' (as was sometimes jocularly remarked between themselves), the Footprints of the Creator might never have been written; or at least, being written, the great culminating points in the argument would have been shorn of their force and power; and the principal facts, and the greater portion of the descriptive geological groundwork of the volume, would have been wanting."

By Mr. Dick's specimens of the then unknown fish, Hugh Miller was enalled to identify the great Russian 
Chelonichthys with the Asterolepis of the Caithness beds, and to reconstruct to a certain extent this monster of the primeval seas. Agassiz says that the remains of the Asterolepis found by Mr. Dick at Thurso indicate a length of from twelve feet four to thirteen feet eight inches. It was the occurrence of this monster among the vertebrates at such an early period of the world's history, that gave Hugh Niller the key-note to that elaborate argument, by which he endeavoured to controvert the development theory of Oken, Lamark, and the author of the Vestiges of Creation.

Mr. Dick not only provided the fragments by means of which the structure of the Asterolepis was wrought out-especially the small medium plate in the cranial buckler, immediately over the eyes, which Professor Sedgwick immediately recognised as " the true finish,"but he discovered the peculiar dental apparatus of the palate of the Dipterus, and he detected the ichthyodorulite of the Homocanthus, which, though already found in the Old Red, were not previously known to exist in Scotland.

Hugh Miller was always most ready to acknowledge his obligations to Robert Dick. "He has robbed himself to do me service," said Hugh Miller. And yet Dick was so modest and unassuming, that he shrank with the utmost sensitiveness from everything like publicity. He had no idea of making himself famous. On the contrary, he "blushed to find it fame" that he had gone out of the ordinary track and done anything worthy of being recorded in scientific books. He was willing, like Keats, that his name should be "writ in water." "I 
am a quiet creature," he said to Hugh Miller, "and do not like to see myself in print at all." When Sir Roderick Murchison made the eulogistic speech about him at Leeds, he said, "That speech has got me into a great deal of trouble." And when Mr. Peach went to the British Association at Aberleen, Dick said to him, "Pray, do not mention me; if anybody asks about me, say that I am well; I want to be let alone." "His unassuming modesty," said Sir George Sinclair, "was as conspicuous as the wonderful amount of his knowledge."

It would be hard to imagine a more devoted lover of science, or a more ardent and unselfish seeker-out of knowledge for its own sake. His success in this respect lay in his earnestness, his enthusiasm, and his persistent perseverance. Though a solitary man, the ardour and purity of his devotion to science saved the health of his moral and mental nature, and enabled him to live to the end of his days, cheerful, happy, and human-hearted. His pursuits elevated his nature, and bore him up against the petty annoyauces of the world.

The amount of voluntary labour which Dick imposed upon himself, in pursuit of his favourite sciences, is something incredible. Every nook and cranny of the county was familiar to lim. The bleak bluff rocks of Dunnet Head were as familiar to him as the shores of Thurso Bay. The hills of Morven and Scaraben were his playgrounds. In summer time, and even in winter, he wandered far and near, always alone. He walked by night to Freswick and Dumbeath in search of the boulder clay and its marine shells. He wandered up Strath 
Halladale in the moonlight, and came home, across the hills, by Braalnabin, to Thurso. Or he would walk across the country, over bog and mire, to Morven top, and be back in time for his day's baking. He hammered among the rocks at Murkle Bay until the moon shone clear in the water. He clambered up and down the rocks at Dunnet Head in search of ferns. In the early mornings, in spring, he went up the banks of the Thurso river to see the flowers unveiling themselves before the light of sunrise. The hills about Reay were among his favourite haunts. There he transplanted the ferns which he had brought from Dunnet Head, so that they might be cheering the wandering botanist when he himself, as he said, was "out of time."

Labour was an absolute necessity for him. "I find it utterly impossible," he said, "to be idle. There is nothing for me but regular labour. If I camnot find any ordinary work to do, I must invent some extraordinary work. I could not be, and would not be, what the world calls a gentleman-that is, standing idle-even though I were paid for it. The mind must be employed, even though what occupies it is doomed to come to an end and pass away into nothingness, and we ourselves with it."

The intellectual labours of men such as Dick are often spoken of as the pursuit of knowledge under difficulties; but they are also the pursuit of knowledge under pleasure. We forget the delight which accompanies the discovery of a new fact, and the enlightenment of a mind thirsting for knowledge. This was one 
of the greatest pleasures of Dick's life. We forget also the elevating and purifying effects of searching after truth. In pursuing knowledge, he was merely serving his higher nature.

Nor did he ever make a parade of what he knew. He was modest and retiring. Others sought him, not he them. He thought, like Newton, that all that we know was as but mere shells on the sea-shore, compared with what must ever remain unknown. And yet those who were adnitted to his intimacy were surprised at the amount of knowledge he had accuired.

"It was impossible," says Dr. Shearer, "for one coming into the merest casual contact with him not to catch up some portion of his own vivid enthusiasm in natural science; and no man was ever better fitted by nature as a luminous and gifted expounder of scientific truth. His conversation was so rich that one always came away surfeited."

"He combined in himself rare powers of original research, and an amazing industry in the pursuit of truth, with a sweet and wimming eloquence which was all his own. His collection of the British Flora is almost unique in its completeness. Looking at the difficulties he encountered in collecting it, his herbarium is an extraordinary tribute to his diligence, skill, and long-continued perseverance."

Dick diligently applied himself to the study of all that lay around him. He noted with wonderful accuracy the lie of a country. He marked upon the map that he carried about with him the faults, and dips, and 
dislocations of the strata ; thus correcting the statements of previous geologists. He was not satisfied with accepting the statements and adopting the conclusions of others. He would not take anything for granted that he could see and observe for himself. When his views as to the nature of the fossil fish, as explained by Hugh Miller, were disputed by scientific men, he said, "Why can't they leave their books, and come here and see for themselves?"

Nor was he in a hurry to comnect himself with those who traced a harmony in all respects between the cosmogony of the Hebrew Scriptures and the indications of geological science. "We think," he said, "that we have deciphered the writing on the selvage of the great volume of the earth; and, lo! we proceed to erect our fragmentary knowledge into a science, and to show its correlation with all the other departments of truth." Again, "Let us watch for facts, and wait." Knowing that Nature herself must ever harmonise with truth, he endeavoured to trace out the workings of the Almighty in the little spot of earth to which he was confined, with lowly and reverent adoration, and with simple, childlike delight.

The number of fossils that he collected was very great. With his usual generosity, he made over a considerable part of them to Hugh Miller. Another portion, containing some of his best specimens, was sold to Mr. Miller of London, for the purpose of paying his debts after the shipwreck of his flour. The remaining fossils were found in his museum after his death. 
The fossils sent to Hugh Miller are now to be found in the Museum of Science and Art at Edinburgh. The collection is marked, "Fossils used by the late Hugh Miller to illustrate his works." The whole of those marked "Thurso" were found by Robert Dick, though his name does not appear on any of them.

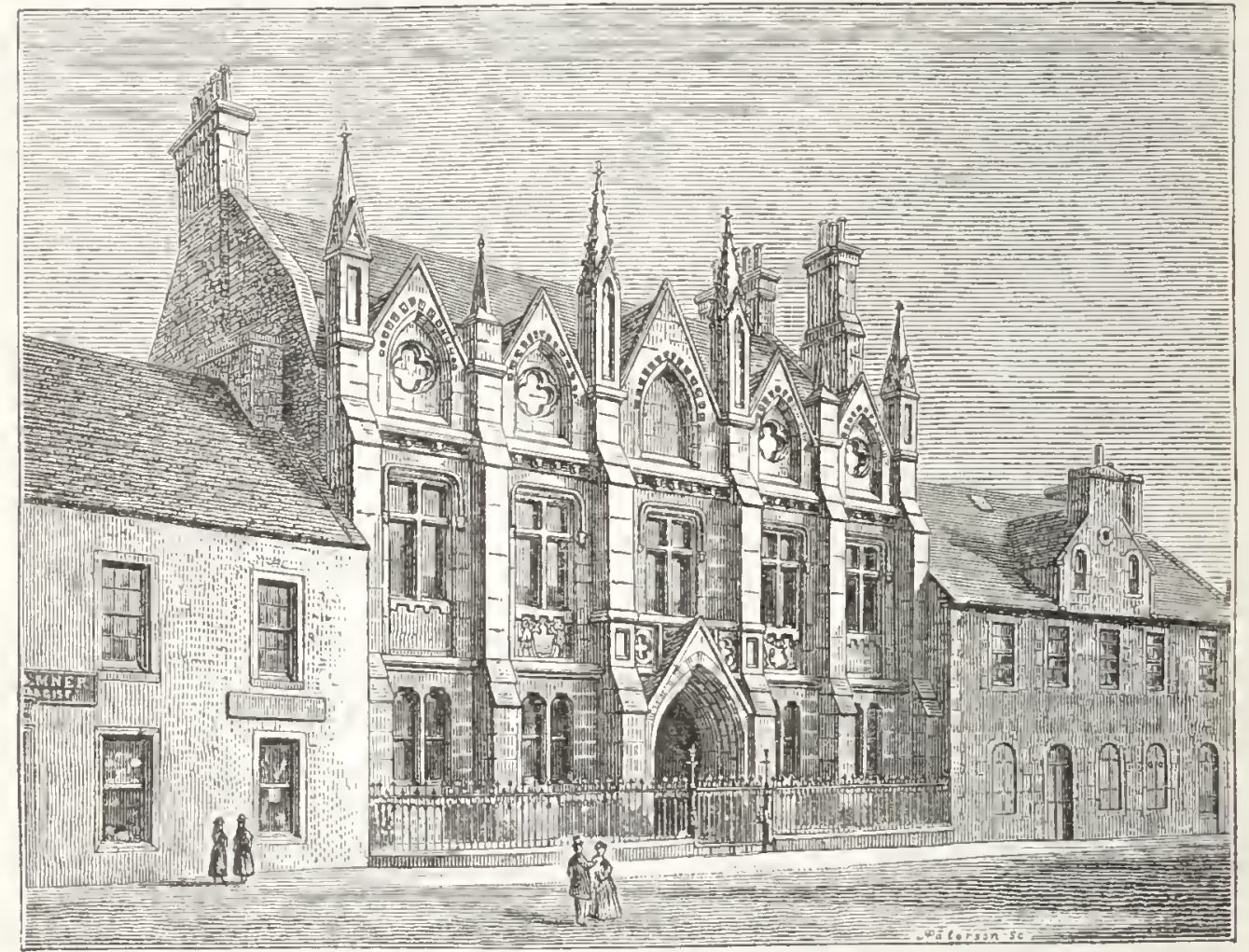

TOWN HALL, THURSO.

But his herbarium also exhibits the best proofs of Robert Dick's industry, judgment, and tenacity of purpose. The collection was made over to the Thurso Scientific Society, by Mr. Alexander, of Dunfermline, Robert Dick's nearest surviving relation. To tell the truth, this extrnordinary collection has been very much neglected. The herbarium consists of about two hundred folios, full of botanical specimens. The grasses and ferns, and in fact all the plants, are beautifully preserved. They 
are carefully gummed on to their respective sheets, and in the case of the Caithness plants, the halitat is always given. The manner in which they are arranged shows the eye of the artist. The mosses are unfinished. We have by us the book which he carried in his side-pocket, still full of the mosses which he was collecting and gumming on at the time of his death.

The herbarium seems to have been thrown into a corner, and laid on the floor. It is full of living moths, and their grubs have already made sad havoc with the collection of grasses in which Dick took so much pride. The Scientific Society of Thurso ought surely to do something to put the collection in proper order. The respect which they entertain for Robert Dick requires this to be done. They will never again possess such another botanist to collect and arrange the plants and grasses, and ferns and mosses, of Caithness.

A few more words about Dick's character. We have said that he was a solitary man. He was for the most part alone with himself. He communed much with his own thoughts. He always made his long journeys on foot alone. "No good work," he sairl, "could be done in company." He har few real friends; and his relatives were far distant.

Under such circumstances, and with such a nature, Dick was in imminent danger of losing the health of his spirit and the just balance of his character. Such a man is often driven to brood on himself; or sell his life to miserable, miserly money-making; perhaps to drink or self-indulgence. But Dick did none of these. His 
love of knowledge and science saved him. Besides, he was childlike in his nature. He had the wonder of a child; he had the feelings of a child. He was always merciful to children. He was blameless, simple, cheerful, in all that he did.

Though he was naturally a man of retiring manners, he was by no means unsociable. He had a great deal of human nature in him. To those who knew him best, he was cheerful and social. He had a vein of innocent fun and satire about him; and he often turned his thoughts into rhyme. Sir George Sinclair said of him, "His temper was naturally cheerful, and even facetious. His comely and animated countenance beamed with intelligence and good humour. His estimable and faithful attendant, who resided with him for the long period of thirty-three years, never heard a hasty word drop from his lips, or saw his bright countenance clouded by an angry frown. The grateful tears which she has so plenteously shed attest the kindly tenor of his domestic life."

Professor Shearer also adds-" "He was held in honour for his scientific attainments by a growing number of the inhabitants, and by the small number of young men whom the little town used to send to the universities; while, by the working men generally, the purity of his life and the independence of his character secured for him a respect, which, to my own knowledge, was never once broken. His moral character was never called in question."

Charles Peach, who knew him so well, said of him, 
"His character was thoroughly without blemish. He never said an ill word of any one; and never repeated anything to another's discouragement. I regret," he adds, "that so many of his curious and original discoveries have been lost, because he made no communication of them to others, and had a special aversion to what he called "blowing his own trumpet."

Dick continued poor to the close of his life. He was content to be poor, so long as he was. independent, and free to indulge his profound yearnings after more knowledge. Though he attended carefully to his business, he was not successful. He was ruined by competition. The shipwreck of his flour reduced him almost to beggary. But he never told his Thurso friends of his losses. He was the last man to "send round the hat." Like Burns, he was "owre blate to seek, owre proud to snool." When his customers left him, he said to one of his friends- "Well, they might not have done it. I have wrought long for them, and I have served them well ; but it cannot be helped now."

Charles Peach, not knowing of his losses, once said to him, that "he would soon be able to save enough money to retire, and give himself up wholly to scientific pursuits." A gloom fell over his countenance. "Oh no!" said he, "I shall never do that." But he added, "Notwithstanding the opposition that has destroyed my trade, I am still here- - a baker after all!" And he smiled at the efforts which had been made to strangle him.

Sir George Sinclair, perhaps not knowing his struggles to live, said after his death - "Mr. Dick's honourable 
desire to earn his livelihood by his own exertions, and the unremitting diligence with which he attended to matters of business, without allowing scientific pursuits to interfere with his daily and respectable calling, have long since attracted my cordial admiration. Iie was always at hand when wanted; and, like Johnson's estimable friend Lovatt,

" 'No summons mocked by chill delay-

No petty gains disdained by pride;

The modest wants of every day

The toil of every day sujplied."

It was fortunate for Dick's memory that he left no debts umpaic. Everything that he owed was paid in full; though little was left for his faithful friend Annie Mackay.

When I went to Thurso, I expected to obtain a good deal of information from her about her old master. But she could give me very little. She could not speak for tears. "He was my good and kind maister!"- that was nearly all that she could tell me. But she showed Ine Dick's house and the bakehouse behind,--now divided into separate tenements.

Little more need be said about Robert Dick. The "unco guid" said hard things of him. They drew a religious moral from the painfulness of his death. Poor self-satisfied creatures! One of Dick's sayings might apply to them. "Some men," he said, "make an image of God after their own hearts, and not after the image of their Maker."

Yet all who knew Dick intimately spoke of him as a 
thoroughly religious man. His was one of those deeply reverent natures that are essentially religious, though not cumbered about with forms or ceremonies or sectarian differences. Indeed, one of the things that drove him from the church was the quarrels of those who were ministers in it. Professor Shearer, of Bradford, says, "My own opinion is strongly that in this man were combined singular powers of thought and the greatest devotion to natural science; and at the bottom of all, a truly devout and earnest spirit."

Another says, "I had a conversation with him on this solemn subject; and I believe 'his right hand touched God's '- to other's it might be in the dark; but Robert Dick knew it. He studied his Bible diligently, and, like all his other studies, his whole soul went into it. He held his Sabbath worship in his own house alone. Whether we look to his upright, frugal, temperate character as a man, or to his wonderful labour and perseverance in his favourite studies, it is difficult to say which most to admire. But I admire above all his loving and reverent spirit."

Robert Dick's life tells its own moral. His manful perseverance in encountering the difficulties of life; his steadfastness, his honesty, his purity; his highmindedness in carrying on his business affair's; his energy and devotedness in cultivating his higher nature;-all these command our admiration.

Thus the man of the humblest condition may at the same time do honour to his calling and elevate the condition of his class. By the diligent use of his spare 
time, he may even add many new facts to the constantly enlarging domain of science. In the case of Dick, how little time was misspent, how much knowledge was gained and communicated,-and all with so much humbleness, modesty, and unselfishness! It is by men such as he that the character of a country is elevated to the highest standard, and raised in the scale of nations.

"Whilst the institutions and customs of men," says Professor Sedgwick, "set up a barrier, and draw a great and harsh line between man and man, the hand of the Almighty stamps His first impress upon the soul of many a person who never rises above the ranks of comparative obscurity and poverty. Hence arises a lesson of great importance,- - that we should learn in our walks through life, in our mingling with the busy scenes of the world, a lesson of practical wisdom, of kindness, of humility, and of regard for our fellow beings."

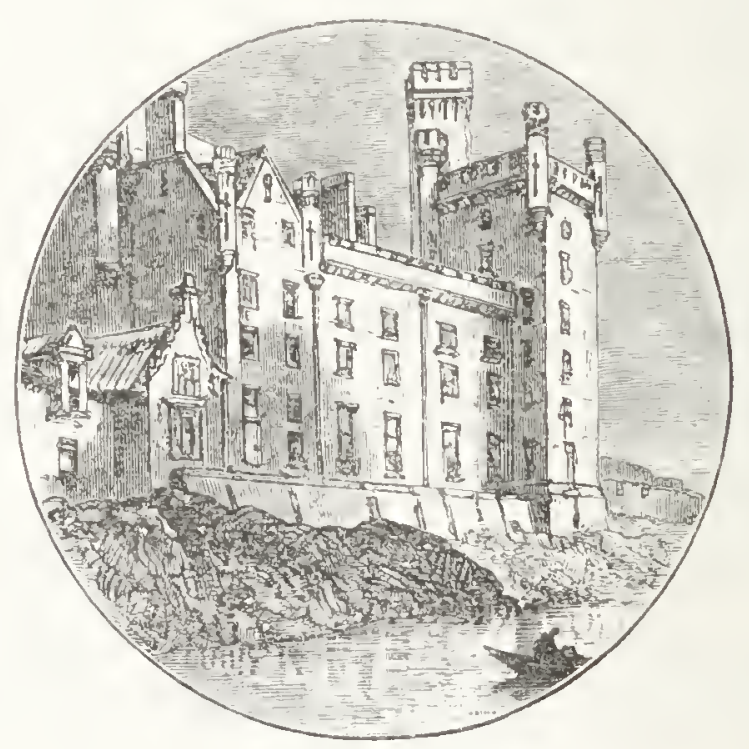




\section{INDEX.}

ABERCrombr family, 7 .

Acharynie, 198, 200.

Aikman, Mr., Tullibody, 17, 40, 48, 193.

Agriculture in Caithness, 33.

Allman, Prof'essor, 266.

Alva, 2.

Al-wick, 31.

Amygdaloid, 277.

Argyll, Duke of, 285.

Asterolepis, 207, 215, 224, 272, $289,362,421$.

Atiantic at Thurso, 24.

Babington, Professor, 266, 341.

Bakehouse, Dick's, 272, 3:23, 351 .

Bakel, life of a, 19; bakers in Thurso, 315.

Balfour, Professor, 74, 266, 291, 294.

Baltic rush, 255, 340 .

Banniskirk, 138.

Barrogill Castle, 28, 211.

Bencheilt, 37, 193, 229.

Bencleuch, Ochil Hills, 3.

Biscuits, Dick's, 49, 396.

Bishop's Palace, 'Thurso, 111, 121.

Botany, Dick's first acquaintance with, 19 ; study of, 50 ; his collection, 254, 264, 426 .

Boulder clay, formation of, 133, 15s; at Freswick, 169, 184 ; at Thurso, 159 ; at Dunbeath, 192.

Boulders, 180, 190, 400.

Brims, geology at, 125 .

British Association, 245, 263.

Brough, 83, 95, 174.

Brown, Dr., 2Ss, 290.

Buckland, Dr., 99, 106, 249.

Busby's book, 99.
Caithness, description of, 26.

Cambuskenneth, 5 .

Carlyle, Mr. T., 2S6, 401.

Castles, old, in Caithmess, 31, 44, 201.

Castle Campbell, 1.

Castlehill, 29, 1 SO.

Castletown, 87, 180.

Chambers, Dr. R., 246, 367.

Character of Dick, 373, 427.

Clett, Holborn Head, 43, 124.

Cley, Norfolk, 241, 243.

Coast scenery of Caithness, 30.

Coccosteus, 100, 107, 127, 139,325, 359.

Colenso, Bislıp), 400.

Competition in Thurso, 153, 313.

Conybeare on fossils in Caithness and Cornwall, 98, 245.

Cornish geology, 245, 250.

Correspondence with Hugh Miller, 100-159.

Coutts, Baroness Burdett, 286.

Creation, one, 305.

DaM's Burn, 10.

Darwin, Mr., 304, 309.

Deil's Brig, Holborn Head, 123.

Devon River, 1.

Dick, Robert,--birthplace, 8 ; scholar, 9,11 ; son of nature, 12, 18 ; treatment at home, 13 ; his selfcontrol, 15; apprenticed to a baker, 17; acquaintance with Botany, 19; a great reader, 20 ; becomes a journeyman, 22 ; re moves from Greenock to Thurso 23 ; begins trade as a baker, 40 , Conchology, 41 ; Botany, 42; Entomology, 44; the boys and 
the baker, 45 ; attends lectures, 47 ; Astronomy and Phrenology, 47 ; studies Botany, 50; buys books, 52 ; buys a microscope, 52 ; walks in the country, 56, 60; hunting for ferns, 61,78 ; journey to Morven top, 65 ; taken for a poacher, 67 ; the "Holy Grass," 73 ; Dorery hills, 78; Dumnet Head, 83; descends the Head, 88 ; studies Geology, 98 ; reads "Old Red Sandstone," 99 ; corresponds with Hugh Miller, 100 ; discovers a Holoptychius, 10s; journey round the Thurso coast, 111 ; the west coast, 119 ; visited by Hugh Miller, 141; death of his father, 151; why he left "the Kirk," 154 ; liis solitary service, 196 ; journey to Freswick, 167 ; to Brough, 172 ; to Dumbeath, 19: ; to Dirlot, 200 ; to Sinclair Bay, 204 ; to Strath Halladale, 208; to Haven of Mey, 211; Dicl's assistance to Hugh Miller, 214; the nnap, 220 ; journey to Gill's Bay, 228; to Bencheilt, 229 ; Dick mourns Hugh Miller's death, 234; becomes acquainted with Mr. Peach, 253 ; interview with a Highlander, 268 ; interviews with Sir R. Murchison, 270 ; Dick's Rliymes, 277; shyncss, 283 : friendship for medical students, 288 ; illncss, 300 ; plants ferns throughout the county, 297, 301; decline of business, 312 ; his honesty, 319 ; Sir Wyville Thomsoll. 323 ; wreck of his flour, 329 ; compelled to sell his fossils, 335 ; " $O$ waft me o'er the deep blue sea," 345 ; a sleepless man, 346 ; recommences a collection of fossils, 348 ; his temperance, 376 ; Dick at home, 378 ; correspondence with Peach, 387 ; in galloping ruin, 395 ; his last walk, 403 ; his illness, 405; his death, 410 ; public funeral, 413; winding-up of his affair's, 414; his library, 415 ; a pension proposed, 415 ; Dick's character, 417 .
Dick, Thomas, Excise officer, 8; second narriage, 10 ; made Supervisor, 20; made Collector of Excise, 43 ; his death, 151.

Dips of Caithness rocks, 131, 218, $227,230$.

Diplopterus, 137, 144, 204.

Dipterus, 137, 214.

Dirlot Castle, 201.

Don, the botanist, 73 .

"Donald's Flittin," 149.

Dorery Hills, 78.

Druidical temple, 229.

Dumbeath, 193.

Duncansby Head, 30 ; Stacks, 166.

Dunmyat, 3.

Dunnet Head, 23, 81; lightlouse, 85 ; cliffs, 144, 172, 296.

Dumnet Loch, 96.

Dunnet Sands, 77, 143.

Durness, 257.

Dwarwick Head, 84.

Egyptology, 381.

Emigration from Caithness, 147, 381.

Fern-Hunting, 61, 76, 78, 89, 296, $341,376$.

Finlayson's lccture, 365.

Flagstones, Caithness, 132, 316.

Flint, liquid, 367 .

Folkinghan, 240.

Forss, 27, 121 ; Water, 388.

Fossil-hunting, 100, 110, 118, 131, 214, 285, 323 ; fossils sold, 335 ; new collection, $348,359,398$.

Free Church, 148, 155.

"Fresh lierring," 139.

Freswick Castle, 168 ; boulder clay at, 169-191; bridge at, 190 .

Freswick, journeys to, $167,178$.

GaELS in Caithness, 27.

Geography of Caithness, 35.

Geology-Dumnet Head, 90 ; Dick's beginnings of, 99, 102 ; not yet a science, 130 ; formation of Caithness, 132 ; boulder clay, 133-154.

Gilchinst, Margaret, 9.

Gilì's Bay, 228. 
Giruigo Castle, 31.

Glaciers, 133, 165.

Gorranhaven, Cormwall, 244.

Gulf Stream, 24, 296.

Gyoes in Caithness, 30, 32, 44, 85, 116.

HaEllan, Loch, 210.

Halie Loch, 96.

Halley's comet, 47.

"Hammers an' chisels," 277.

Harold, Mrs., 409.

Harpsdale, 164, 178.

Hart's-tongue fern, 298, 301.

Harvieston, 2.

Herbarium, Dick's, 254, 274, 280, $380,426$.

Highlanders, emigration of, 147, 381.

Hills in Caithness, 33, 65.

Holborn Head, 24, 43, 81, 123, 144.

Holoptychins, 101, 104, 110, 139, 214.

Holothuria, Peach's, 247.

Holy Grass, 73, 255, 344.

Homocanthus, 217.

Honesty of Dick, 319

Hoplocanthus, $\approx 17$.

Hoy, Old Man of, 24, 115.

ICEBERGS, 133, 163, 165, 192.

JAmieson, Mrr., Ellon, 386.

John o' Groat's, 23, 182.

Johnson, Dr., 291.

KIRK, attendance at, 153, 267.

Knox, John, 6.

LAPLAND flora, 340.

Layton, Rev. J., 242.

Lighthouse, Dunnet Head, S5.

Linnæus and mosses, 295.

Lion-hunters, 282.

Lochs in Caithness, 32 ; on Dunnet Head, 83, 95.

Macculloch, Dr. 257.

Mackay, Annie, 43, 315, 415, 430.

Macleod, Dr. Norman, 267.

Maiden Pap, 65.
Maps of Caithness, 35, 219, 272.

Medical students, 288.

Meiklejohn, Dr., 288, 30 S.

Menstrie, 2, 4.

Metauorphic action, 366.

Mey, Haven of, 211.

Microscopic shells, 369 .

Miller, John, F.G.S., 330, 355, 363, 407.

Miller, Hugh - Oll Red Sandstone, 99 ; correspondence with Dick, 100 ; on working-men Geologists, 105 ; visits Thurso, 141 ; description of the coast, 144 ; correspondence with, 100, 159-191, $214-234$; the fairies, the biography, 236.

Monk of Cambray, 261.

Moraines, 12:2, 397.

More, Locl, 196.

Morven, 33, 65 .

Moss-hunting, 295, 321, 397.

Mountrins of Caithness, 32, 65.

Murchison, Sir R., 218, 257, 270, 332,411 .

"NAIL" at Stromness, 354.

Natural History Society, Thurso, $384,486$.

Nichol, Professor, 270.

Nesses of Caithness, England, etc., 26.

Noss Head, 204.

Notcutt, Mr., botanist, 265, 343.

Ochit, Hills, 1, 2, 12.

Old Red Sandstone, 86, 91, 99, 114, $177,219,261$.

Ord of Caithness, 35.

Orkney Islands, 24.

Osteolepis, 106, 214.

Owen, Professor, 216, 342.

PArk, Mungo, 295, 372.

Peach, Charles IV.- - his birth, 239 ; education, 240 ; Riding Officer in the Coastguard, 241 ; studies zoology, 242 ; his various removals, 243 ; Gorranhaven, Cornwall, 244 ; collects marine famm, and studies geology, 245 ; reads a paper at British Association. 
245 ; at York, 246 ; his microscope, 248 ; promoted to Landing Waiter at Fowey, 249 ; promoted to Comptroller at Peterhead, 251; removed to Wick, 252; interviews with Robert Dick, 252; researches at Durness, Sutherlandshire, 257 ; finds new fossils, 258-9; Sir Roderick Murchison, 272 ; rhymes sent to Peach, 277 287 ; limestone fossils, 368 ; entertained by Dick, 375; finds more fossils, 389 ; his labour, 391 ; retirement, 392; contimes his researches, his honours, 393 ; his photograph, 394 ; last letter from Dick, 409.

Pension proposed for Dick, 415.

Pentland Firth, 27, 86.

"Peri," the, 377.

Perichthys Dichi, 390.

Peterhead, Charles Peach at, 251.

Phrenology, 48.

Picts, the, 4, 28.

Poacher, Dick taken for a, 67.

"Prince Consort," 328.

Pringle, Mr., Farmer's Gazette, 344.

Pterygotus, 390.

Public funeral, Dick's, 413.

Pudding Gyoe, 116.

Rangag, Loch, 230.

Ratter, Burn of, 211.

Religion, Dick's, 372, 431.

Revenue service, $241,392$.

Rhyming faculties, $277,287$.

Roals in Caithness, 34.

Roses, Caithuess, 292, 309, 341.

Rough Head, 85.

Royal Fern, the, 296.

Salmon at 'Thurso river, 23.

Salter's lecture, 360.

Scandinavians in Caithness, 27.

Scarskerry, 227.

Scrabster Burn, 118, 122.

Scrabster Roads, 82, 121.

sea bird, cry of the, 25 .
Sea, description of the, 24, 30,41, 81, 119.

Sedgwick, Professor, 215, 257, 432.

Shearer, Dr., 306, 372, 374, 421.

Shearer, Professor, 234, 428.

Shells, marine, 160, 163, 170, 184, 194, 207.

Shurery, Ben, 207.

Sinclair, Sir George, 285, 410, 421.

Sinclair, Sir Joln, 37.

Sinclair Bay, 204.

Skerries, Pentland, 28, 168.

Skerry Ben, 65.

Slater's monument, 124, 144.

Spring in the North, 56.

Standing Stone, Tullibody, 5.

Strathbeg, 203.

Strath Halladale, 208.

Stemster, Loch, 230.

Stroma, island of, 39, 182.

Sunday in Scotland, 155, 267.

Temperance of Dick, 55, 376.

Thomson, Sir IVyville, 323.

Thurdistoft, 163 .

Thurso,-Dick goes to, 23 ; trarle at, 34; fossiliferous beds near, 112 ; old church, 274 ; improvement of, 316.

'Thurso Bay, 23, 41, 111, 118.

Thurso Castle, 37, 54, 432.

Thurso River, 59, 159, 365.

Thurso East, 111.

'Trees in Caithness, 29, 87.

Tullibody, 1, 17, 21.

Verses, Robert Dick's, 277-S9, 345.

WALKING, Dick's, 55.

Wansford, 240.

Wart Hill, 182.

Weydale, 125, 134, 136, 350 .

Wick, 30, 252.

Wilson's Lane, Thurso, '23, 271.

Witness newspaper, 99, 135.

Zoology of Cornwall, 244 ; of Petorhead, 251. 


165

${ }_{0}{ }_{2}$ 
s.

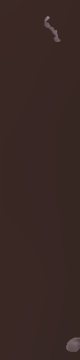




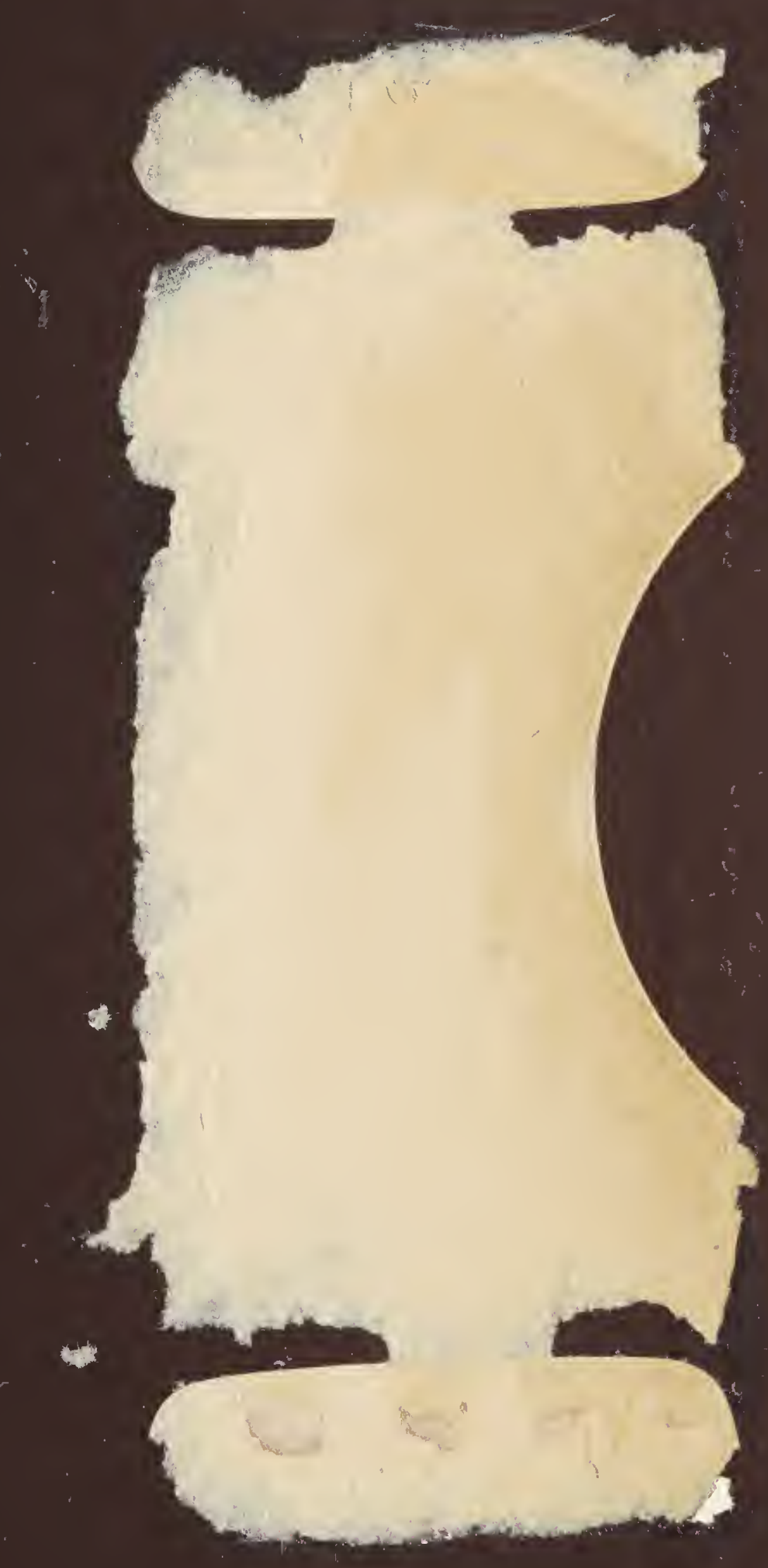




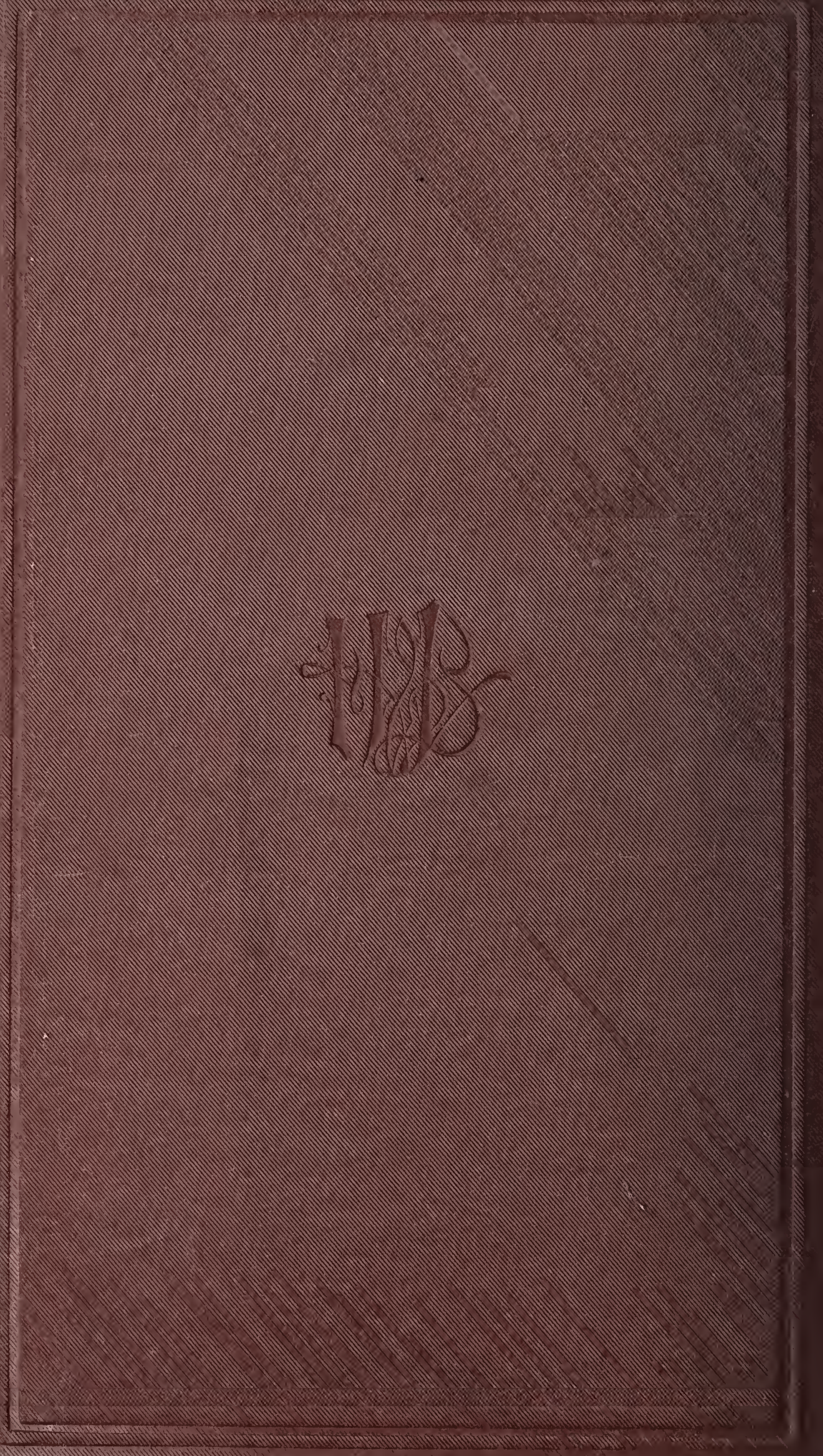

